\title{
A Commitment is a Commitment is A Commitment?
}

\section{Why States Constrain and Customize Their Commitments \\ to the International Criminal Court}

\author{
Dissertation zur Erlangung des Doktorgrades \\ der Sozialwissenschaftlichen Fakultät \\ der Georg-August-Universität Göttingen
}

\author{
vorgelegt von \\ Julia Hagen \\ geboren in Bad Säckingen
}

Göttingen, 2019 
Thesis Committee

First Supervisor: Prof. Dr. Anja Jetschke

Second Supervisor: Prof. Dr. Dr. h.c. Kai Ambos

Third Supervisor: Prof. Dr. Christoph Hönnige

Disputation: $31^{\text {st }}$ May 2018 


\section{Foreword}

The present work deals with states' power political behavior towards the International Criminal Court (ICC). Its purpose is to critically evaluate the incentives structures for states that arise from the institutional design of the court. It will be argued that states constrain and customize their commitments in order to leave room for strategical behavior while being a state party to the court. This is due to the states' possibilities to solve cooperation problems of international law with the International Criminal Court. The states (in the absence of a strong enforcement mechanism) do not know which of the other states will comply with the law and which will not. Their own compliance can become a strategic disadvantage in relation to states that don't comply.

The central finding of the study is that those states constrain and customize the commitments the least that have a high level of democracy and ratified a high number of treaties of humanitarian law and human rights law. That shows that the ICC is a possibility to solve cooperation problems of international law. With the ICC a permanent international institution is provided that is able to investigate and prosecute genocide, crimes against humanity, war crimes and the crime of aggression. The creation of such a court reduces monitoring costs that would occur when those norms were otherwise monitored by many different monitoring agencies. Moreover, the self-binding to such a court increases the credibility of commitment already made to humanitarian law and human rights law.

For the empirical study, data is gathered up to August 2016. Since then, some things have changed. Two states withdrew from the Rome Statute. Burundi in October 2017 and the Philippines in March 2019. South Africa and Gambia announced their withdrawal in 2016, but finally decided to stay states parties. Malaysia announced their intention to ratify the Rome Statute in 2019, but finally decided not to do so. Thus, the ICC has currently (May 2019) 122 states parties. The crime of aggression, as fourth core crime, came into force in 18th July 2018, but still only 38 states ratified the relating amending agreement. The practice of constraining and customizing commitments to the ICC is still alive.

For the sake of informational freedom and swarm intelligence this study is published online instead of hiding its arguments and findings in the bookshelves of academia. It is the hope that this work provides inspiration to anyone who would like to build of the thoughts provided here in order to find better ideas to bind states more closely to the goals of humanitarian law and human rights. 


\section{Contents}

$\begin{array}{ll}1 & 12 \text { Introduction }\end{array}$

1.1 Empirical Puzzle: A Commitment is a Commitment is a Comimtment? 14

1.2 State of the Art and Research Gaps: Black Box States Parties . . . . . 18

1.3 Delegation Dilemma and Constrained and Customized Commitments. . 21

1.4 Research Design: Building an Index and Testing Determinants . . . . . 24

1.5 Scientific and Political Relevance . . . . . . . . . . . . . . . 25

1.6 Structure of the Work $\ldots \ldots \ldots \ldots$

2 Following Universal Norms or Making Rational Decisions? States' Com-

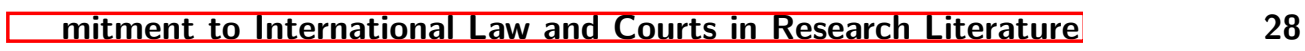

2.1 Commitment to International Law . . . . . . . . . . . . . 30

2.1.1 The Problem of Anarchy in International Relations. . . . . . . 30

2.1 .2 Theories on States' Commitment to International Law . . . . . . 31

2.1.3 Empirical Studies on States' Commitment to International Law. 40

2.2 Delegation of Authority to the International Criminal Court . . . . . . . 43

2.2.1 The Problem of Non-Compliance with International Law . . . . 43

2.2 .2 Theories on States' Delegation to International Courts . . . . . . 53

$2.2 .3 \quad$ Empirical Studies on Delegation to International Courts . . . . . 60

2.3 Research Gaps and Contributions to the Literature . . . . . . . . . . . 64

2.3.1 Opening the Black Box of States Parties to the ICC . . . . . 64

$2.3 .2 \quad$ Different Incentives in Delegating Authority to the ICC . . . . 65

3 Theory of States' Constraining and Customizing Commitments to the ICC 68

3.1 Guardian of Humanitarian Law and Human Rights Law . . . . . . . . 70

3.2 Why States Want the ICC - Incentives to Ratify the Rome Statute. . . 76

3.2 .1 Privileges of Being a State Party to the ICC . . . . . . 76

3.2 .2 Support in Dealing with the Past . . . . . . . . . . . . . . . 85

3.2 .3 Solving Cooperation Problems with the ICC $\ldots \ldots \ldots . . . .68$

3.3 Why States Have to Fear the ICC - Obstacles in Ratifying . . . . . 97

3.3 .1 Missing Institutional Counterparts . . . . . . . . . . . . 97

3.3.2 What if the ICC is too Weak? Fear of Politicization . . . . . . 107

3.3 .3 What if the ICC is too Strong? Fear of Juristocracy . . . . . . 115

3.4 States Constrain and Customize their Commitments to the ICC. . . . . 123

3.4.1 The Delegation Dilemma of States: Ratification or Not? . . . . . 123

3.4 .2 Constraining Courts Solving the Delegation Dilemma . . . . . . 125 
3.4.3 States Customizing and Constraining their Commitments . . . . 129

3.5 Solving Cooperation Problems with the ICC . . . . . . . . . . . . . 136

3.5.1 Cooperation Problems of International Law . . . . . . . . . . . . 136

3.5.2 Reducing Costs of Monitoring versus Fear of Monitoring . . . . . 138

3.5.3 Enhancing Credibility versus Window Dressing . . . . . . . . . . 141

4 An Index as Summary Measurement for Comprehensive Commitment 147

4.1 Modeling Ways of Constraining and Customizing Commitments . . . . . 147

4.1 .1 Joining the Rome Statute $(\operatorname{Dim} 1)$. . . . . . . . . . . . . . . . . 148

4.1 .2 Amending APIC, Art. 8 and Crime of Aggression (Dim 2) . . . . 149

4.1 .3 Modifying APIC, Art.8 and Crime of Aggression (Dim 3) . . . . 154

4.1 .4 Implementing Norms on Complementarity \& Cooperation (Dim 4) 156

$4.1 .5 \quad$ Triggering Investigations and Prosecutions (Dim 5) . . . . . . . . 157

4.2 Data and Methods I - Dimension Reduction and Index Building . . . . 161

4.2 .1 Case Selection and Data Set l . . . . . . . . . . . . . . . 161

4.2.2 Methods of Data Collection and Data Analysis I . . . . . . . . . 163

4.3 Results I - The Index of Commitment to the ICC . . . . . . . . . . . . . 167

4.3.1 Variation in the Different Dimensions of Commitment . . . . . . 167

4.3 .2 The Index of Commitment to the ICC . . . . . . . . . . . . . . . 175

4.3 .3 Patterns of Commitment to the ICC . . . . . . . . . . . . 178

5 Testing the Explanatory Power of Solving International Cooperation Prob-

$\begin{array}{ll}\text { lems with the ICC } & 183\end{array}$

5.1 Model and Operationalization . . . . . . . . . . . . . . . . . 183

$5.1 .1 \quad$ Hypotheses on Solving Cooperation Problems . . . . . . . . . . . 183

5.1 .2 Dependent Variables . . . . . . . . . . . . . . . . . . . . . . . . . 184

5.1 .3 Independent Variables . . . . . . . . . . . . . . . . . . . . . . . . 185

5.1 .4 Control Variables . . . . . . . . . . . . . . . . . . 186

5.2 Data and Methods II - Testing Hypotheses with Regression Analyses. . 192

5.2 .1 Case Selection and Data Set III . . . . . . . . . . . . . . . . . . 192

5.2 .2 Methods of Data Collection and Data Analysis II . . . . . . . . . 193

5.3 Results II - The Explanatory Power of Solving Cooperation Problems . 197

5.3.1 Explaining States' Positions on the Index of Commitment . . . . 197

5.3 .2 Explaining States' Ratification the Rome Statute . . . . . . . . . 212

6 Conclusion and Outlook 227

6.1 Summary of the Results . . . . . . . . . . . . . . . . . 227 
6.2 Contribution to Research on the ICC . . . . . . . . . . . . . . . . 229

6.3 Limits of Empirical Results and Need for Further Research . . . . . . 231

6.4 Why Constrained Commitments Can Still Lead to Strong Bonds . . . . 233

$\begin{array}{llr}7 & \text { Appendices } & 237\end{array}$

7.1 List of States Parties to the Rome Statute (08-2016) . . . . . . . . . . . 237

7.2 Puzzle: Ratification and Democracy (08-2016) . . . . . . . . . . . . . . . 238

7.3 List of Treaties on Humanitarian Law (08-2015) . . . . . . . . . . . . . . 239

7.4 List of Treaties on Human Rights (08-2015)] . . . . . . . . . . . . . 240

7.5 Examination of Robustness: Index of Commitment to the ICC . . . . 241

7.6 Index of Commitment to the ICC . . . . . . . . . . . . . . . . . 244

7.7 Correlation Matrix - Dependent and Independent Variables . . . . . . . 245

7.8 Regression Analyses with Civil Law and Presidential System … . . 246

7.9 Database \& Codebook I: Index of Commitment (DV) . . . . . . . . 248

7.10 Database \& Codebook II: Determinants of Commitment (IV) . . . . . . 251

$\begin{array}{ll}\text { References } & 255\end{array}$ 


\section{List of Abbreviations and Acronyms}

\begin{tabular}{|c|c|}
\hline $\mathrm{AC}$ & Andean Community \\
\hline ACHR & American Convention on Human Rights \\
\hline AfChHPR & African Charter on Human and Peoples' Rights \\
\hline AfCtHPR & African Court of Human and Peoples' Rights \\
\hline AI & Amnesty International \\
\hline AL & Arab League \\
\hline APIC & Agreement on the Privileges and Immunities of the ICC \\
\hline Art. & Article \\
\hline ASEAN & Association of Southeast Asian Nations \\
\hline ASP & Assembly of States Parties to the ICC \\
\hline AU & African Union \\
\hline BIA & Bilateral Immunity Agreement \\
\hline BTI & Bertelsmann Transformation Index \\
\hline CAN & Communidad Andina de Naciones \\
\hline CARICOM & Caribbean Community \\
\hline CAT & $\begin{array}{l}\text { Convention Against Torture and Other Cruel, Inhuman or Degrading Treatment or } \\
\text { Punishment }\end{array}$ \\
\hline CCPR & International Covenant on Civil and Political Rights \\
\hline CEDAW & Convention on the Elimination of All Forms of Discrimination against Women \\
\hline CERD & International Convention on the Elimination of All Forms of Racial Discrimination \\
\hline CESCR & International Covenant on Economic, Social and Cultural Rights \\
\hline CIA & Central Intelligence Agency \\
\hline CICC & Coalition for the International Criminal Court \\
\hline COE & Council of Europe \\
\hline COMESA & Common Market for Eastern and Southern Africa \\
\hline CRC & Convention on the Rights of the Child \\
\hline DRC & Democratic Republic of the Congo \\
\hline DSB & Dispute Settlement Body \\
\hline DV & Dependent Variable(s) \\
\hline EAC & East African Community \\
\hline ECCC & Extraordinary Chambers in the Courts of Cambodia \\
\hline ECJ & European Court of Justice \\
\hline ECOWAS & Economic Community of West African States \\
\hline ECHR & European Court of Human Rights \\
\hline EFTA & European Free Trade Association \\
\hline $\mathbf{E U}$ & European Union \\
\hline FH & Freedom House \\
\hline GATT & General Agreement on Tariffs and Trade \\
\hline GC & Geneva Conventions \\
\hline GDP & Gross National Product \\
\hline $\mathrm{HC}$ & Hague Conventions \\
\hline HL & Humanitarian Law \\
\hline HRW & Human Rights Watch \\
\hline HR & Human Rights \\
\hline IACtHR & Inter-American Court of Human Rights \\
\hline ICC & International Criminal Court \\
\hline ICCPR & International Convenant on Civil and Political Rights \\
\hline ICESCR & International Convenant on Economic, Social and Cultural Rights \\
\hline ICJ & International Court of Justice \\
\hline ICL & International Criminal Law \\
\hline ICRC & International Committee of the Red Cross \\
\hline
\end{tabular}




\begin{tabular}{|c|c|}
\hline ICSID & International Center for Settlement of Investment Disputes \\
\hline ICT & International Criminal Tribunal \\
\hline ICTR & International Criminal Tribunal for Rwanda \\
\hline ICTY & International Criminal Tribunal for the former Yugoslavia \\
\hline IHT & Iraqi High Tribunal \\
\hline IL & International Law \\
\hline IMT & International Military Tribunal at Nuremberg \\
\hline IMTFE & International Military Tribunal for the Far East \\
\hline IO & International Organization \\
\hline IR & International Relations \\
\hline ITLOS & International Tribunal for the Law of the Sea \\
\hline IV & Independent Variable(s) \\
\hline KSC & Kosovo Specialist Chambers \\
\hline KWCT & Kosovo War Crimes Tribunal \\
\hline LAS & League of Arab States \\
\hline Mercosur & Mercado Común del Sur \\
\hline NATO & North Atlantic Treaty Organization \\
\hline NGO & Non-Governmental Organization \\
\hline OAS & Organization of American States \\
\hline OAU & Organization of African Unity \\
\hline OHCHR & Office of the United Nations High Commissioner for Human Rights \\
\hline OLS & Ordinary Least Squares \\
\hline OTP & Office of the Prosecutor \\
\hline para. & paragraph \\
\hline PIF & Pacific Islands Forum \\
\hline PTS & Political Terror Scale \\
\hline RO & Regional Organization \\
\hline SAARC & South Asian Association for Regional Cooperation \\
\hline SCSL & Special Court for Sierra Leone \\
\hline SPSC & Special Panels for serious Crimes in Timor-Leste \\
\hline STL & Special Tribunal for Lebanon \\
\hline TAN & Transnational Advocacy Network \\
\hline TANs & Transnational Advocacy Networks \\
\hline $\mathbf{T} \mathbf{J}$ & Transitional Justice \\
\hline TJDB & Transitional Justice Data Base \\
\hline TRC & Truth and Reconciliation Commission \\
\hline TRCs & Truth and Reconciliation Commissions \\
\hline UCDP & Uppsala Conflict Data Program \\
\hline UN & United Nations \\
\hline UNCLOS & United National Convention on the Law of the Sea \\
\hline UNO & United Nations Organization \\
\hline UNTS & United Nations Treaty Series \\
\hline UDHR & Universal Declaration of Human Rights \\
\hline UN-GA & United Nations General Assembly \\
\hline UN-ICC RA & UN-ICC Relationship Agreement \\
\hline UNSC & United Nations Security Council \\
\hline USA & United States of America \\
\hline VCLT & Vienna Convention on the Law of Treaties \\
\hline WTO & World Trade Organization \\
\hline WTO-DSB & World Trade Organizations' Dispute Settlement Body \\
\hline
\end{tabular}




\section{List of Figures}

1 States Parties to the Rome Statute . . . . . . . . . . . . . . . 15

2 States Parties to the Rome Statute (Democracies and Non-Democracies) . . . 16

3 Gap between Commitment and Compliance . . . . . . . . . . . . . . . 48

$4 \quad$ Establishing Courts Filling 'Partly' the Gap of Commitment and Compliance 49

5 States Constraining and Customizing their Commitments to the ICC . . . . . 69

$6 \quad$ Relationship of First and Secondary Level of International Law . . . . . . . . 74

7 Monitoring Humanitarian Law, Human Rights and Int. Criminal Law. . . . . 91

$8 \quad$ Fear of Politicization and Juristocracy . . . . . . . . . . . . . . . . . . . . . . . . . . . . .

$9 \quad$ Delegation Dilemma of States towards the ICC . . . . . . . . . . . . . . 125

10 Solving Cooperation Problems with the ICC . . . . . . . . . . . . . . . 138

11 States Parties to the APIC . . . . . . . . . . . . . . . . . . . . . . . . 169

12 States Parties to the Amendment to Article 8 . . . . . . . . . . . . . 170

13 States Parties to the Amendment on the Crime of Aggression . . . . . . . . . 171

14 Implementation of Law on Complementarity to the ICC . . . . . . . . . . . 173

15 Implementation of Law on Cooperation with the ICC . . . . . . . . . . . 173

16 Frequency Distribution of the States' Index Positions . . . . . . . . . . . . . . 175

17 Streamlined Frequency Distribution of the States' Index Positions . . . . . . 175

18 Frequency Distribution of the States' Index Positions by Ratification . . . . . 176

19 Grouped Frequency Distribution of the States' Index Positions . . . . . . . . 177

20 Causal Mechanism - Commitment and Solving Cooperation Problems . . . . 184

21 Scatterplot - Index and Political Freedom in the World (Reversed) . . . . . . 198

22 Scatterplot - Index and Compulsory Jurisdiction ICJ . . . . . . . . . . . . . . 199

23 Scatterplot - Index and Ratified Humanitarian Law . . . . . . . . . . . . . . 200

24 Scatterplot - Index and Ratified Geneva Law . . . . . . . . . . . . . . . . . 201

25 Scatterplot - Index and Ratified Human Rights . . . . . . . . . . . . . . . 202

26 Level of Political Freedom by Ratification of the Rome Statute . . . . . . . . 213

27 Compulsory Jurisdiction ICJ by Ratification of the Rome Statute. . . . . . . 214

28 Commitment to Humanitarian Law by Ratification of the Rome Statute . . . 215

29 Commitment to Geneva Law by Ratification of the Rome Statute. . . . . . . 216

30 Commitment to Human Rights by Ratification of the Rome Statute . . . . . 216

32 Adj. Pred. through Humanitarian Law (Democracies vs. Non-Democracies) . . 224

31 Adj. Pred. through Com. Jur. ICJ (Democracies vs. Non-Democracies) . . . . . 224

33 Adj. Pred. through Geneva Law (Democracies vs. Non-Democracies). . . . . . 225

34 Adj. Pred. through Human Rights (Democracies vs. Non-Democracies) . . . . 226

35 Frequency Distribution - Index (Scores per Variable) . . . . . . . . . . . . . . 241

$36 \quad$ Frequency Distribution - Index (Scores per Dimension) . . . . . . . . . . . . 242

$37 \quad$ Frequency Distribution - Index (Ratification as Strongest Factor)] . . . . . . . 243 


\section{List of Tables}

1 Probability of Self-Enforcement Due to Compliance Mechanisms . . . . . . . 47

$2 \quad$ International and Regional Courts and Tribunals . . . . . . . . . . . . . 51

3 Minimum and Maximum Scores - Ratification of Humanitarian Law . . . . . 144

4 Minimum and Maximum Scores - Ratification of Human Rights Law . . . . . 144

5 Modeling Comprehensive Commitments to International Courts. . . . . . . . 148

$6 \quad$ Modeling Customized and Constrained Commitments to the ICC . . . . . . 149

7 Overview on Dimensions and Variables . . . . . . . . . . . . . . . . . 164

8 Scores of the Dimensions of the Index of Commitment to the ICC . . . . 166

$9 \quad$ Frequencies - Dimensions of Commitment . . . . . . . . . . . . . . . . . 167

$10 \quad$ States Parties and Non-Party States to the Rome Statute . . . . . . . . . . . 168

11 States Parties and Non-Party States to the APIC . . . . . . . . . . . . . . . 170

12 States Parties to the Amendment to Article 8 . . . . . . . . . . . . . . . . 171

13 States Parties to the Amendments on the Crime of Aggression . . . . . . . 171

14 States Parties Article 8 \& Democracy Dummy 2015 . . . . . . . . . . . . . . 171

15 States Parties Crime of Aggression \& Democracy Dummy . . . . . . . . . . . 172

16 States Involved in Armed Conflicts 2000-2015 by Ratification Status . . . . . 174

18 Contingency Table - States Parties ICC \& States Parties EU . . . . . . . . . 178

19 Contingency Table - Commitment to the ICC \& States Parties EU . . . . . . 178

17 Groups Within the Index of Commitment to the ICC . . . . . . . . . . . . . 179

20 Contingency Table - States Parties ICC \& States Parties Mercosur . . . . . . 180

21 Contingency Table - Commitment to the ICC \& States Parties Mercosur . . 180

22 Contingency Table - States Parties ICC \& States Parties CAN . . . . . . . . 180

23 Contingency Table - Commitment to the ICC \& States Parties CAN . . . . . 180

24 Contingency Table - States Parties ICC \& States Parties AU . . . . . . . . . 181

25 Contingency Table - Commitment to the ICC \& States Parties AU . . . . . . 181

26 Contingency Table - States Parties ICC \& States Parties ASEAN . . . . . . 181

27 Contingency Table - Commitment to the ICC \& States Parties ASEAN . . . 182

28 Summary Statistics - Determinants for Commitment to the ICC . . . . . . . 191

29 Explaining States' Positions on the Index of Commitment (HL) . . . . . . . . 204

30 Size of Coefficients of the Three Explanatory Variables (HL) . . . . . . . . . . 207

31 Explaining States' Positions on the Index of Commitment (GL) . . . . . . . . 208

32 Size of the Coefficients of the Three Explanatory Variables (GL) . . . . . . . 209

33 Explaining States' Positions on the Index of Commitment (HR) . . . . . . . . 210

34 Size of the Coefficients of the Three Explanatory Variables (HR) . . . . . . . 211

35 Comparison of Coefficients of Explanatory Variables in Full Models . . . . . . 212

36 Contingency Table - States Parties ICC \& Comp. Jurisdiction ICJ . . . . . . 214

37 Explaining States' Ratification of the Rome Statute (HL) . . . . . . . . . . . 218 
38 Probabilities for Ratification of the Rome Statute in Full Model (HL) . . . . 220

39 Explaining States' Ratification of the Rome Statute (GL) . . . . . . . . . . . 221

40 Probabilities for Ratification of the Rome Statute in Full Model (GL) . . . . 222

41 Explaining States' Ratification of the Rome Statute (HR) . . . . . . . . . . . 223

42 Probabilities for Ratification of the Rome Statute (Full Model HR) . . . . . . 225

43 Contingency Table - Ratification of the Rome Statute \& Political Freedom . 238

44 List of Humanitarian Law Treaties . . . . . . . . . . . . . . . . . . . . . 239

45 List of Human Rights Treaties . . . . . . . . . . . . . . . . . . . . . 240

46 Dimensions of the Index - Scores per Variables . . . . . . . . . . . . . . . . 241

47 Dimensions of the Index - Scores per Dimension . . . . . . . . . . . . . . . 242

48 Dimensions of the Index - Ratification as Strongest Factor . . . . . . . . . . 243

49 Cross-Correlation Table (All Variables) . . . . . . . . . . . . . . . . 245 


\section{Introduction}

There is an increasing legalization of international relations (Abbott et al. 2000) that can be described as uneven (Goldstein et al. 2000), unequally institutionalized (Zangl/Zürn, 2004), pluralistic (Berman, 2007), fragmented (Fischer-Lescano/Teubner, 2007), and in disorder (Walker, 2008). Since the end of Cold War this process has been catalyzed by an increasing proliferation of international judicial bodies which includes courts, arbitration bodies or dispute settlement mechanisms (Romano, 1999, Kingsbury, 1999, Alter 2014). It is accompanied by 'political jurisprudence' (Shapiro, 1981) and a general trend of 'judicialization' of politics both on the national and the international level (Vallinder, 1995, Stone Sweet, 1999, Slaughter, 2000a Hirschl, 2004). International courts and tribunals are created to monitor norm compliance, to give legal advice, to settle disputes legally and civilly, and in the best case to hold states and individuals accountable and thereby enforce international law (Shelton, 2009). They have done this in the hope of filling in the gap between the states' voluntary self-commitment to international agreements and their actual compliance with international law

On 17 July 1998 the Rome Statute of the International Criminal Court was adopted and on 1 July 2002 it entered into force and started to unfold in The Hague. It is the first permanent international court that is able to hold individuals accountable for four core crimes (jurisdiction ratione materiae): the crime of genocide (art.6), crimes against humanity (art.7), war crimes (art. 8) and the crime of aggression (art. 5, para. 1(a) and art. 8 bis, amendment to the Rome Statute of the ICC on the Crime of

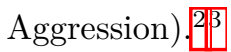

From the view of political science it is puzzling that so many states, even nondemocratic states joined the ICC, since international institutions that hold individuals accountable can be considered a serious intrusion into national sovereignty (Sim-

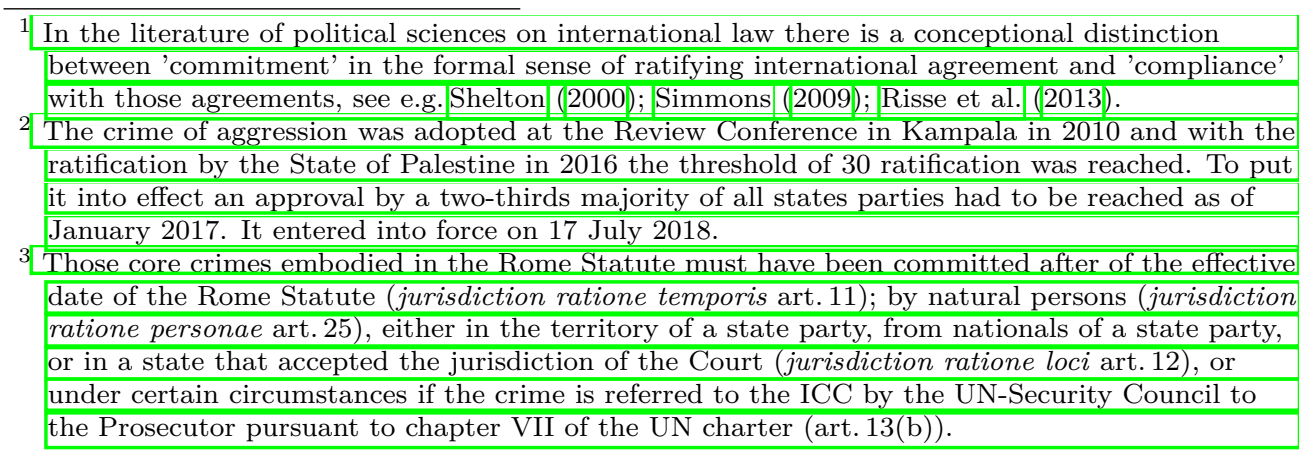


mons/Danner, 2010 Katzenstein, 2014). At the same time, there are frequent cases of non-cooperation by the states parties. One such example is the case of the Sudanese President Omar al-Bashir, who could passed unhindered through Chad, Kenya, Djibouti, Malawi and South Africa, although an arrest warrant had been issued against him and all the countries in question were parties to the ICC.

This shows that the commitments to the ICC are not equally strong. They do not all have the same degree of self-obligation to the Statute of Rome. Even among the states parties there seem to be huge differences. Becoming a state party to the ICC is not enough for supporting the court. However, what then explains the states extent of commitment to the ICC?

This work presents an empirical measure for a comprehensive commitment to the ICC that is able to visualize the diverging commitment behavior of states. Comprehensive commitment describes the self-binding behavior of states beyond the ratification of the Rome Statute, including the commitment to the additional and amending agreements, creation of interpretative declarations, the implementation of the core norms of the Rome Statute into national law and the active use of this court in case of potential norm violations.

As we will see, only a few states commit themselves comprehensively. Only 26 of 195 states have none or hardly any constraints or customization and thus have made a comprehensive commitment to the ICC, such as the Germany, Belgium or Croatia. In fact, most of the states parties to the court have constraints and customized commitments that are at least in part so strong that their commitment behavior is almost comparable to those of non-party states, such as Bangladesh, Burundi or Afghanistan. Conceptually, the study draws on the delegation dilemma to explain, why states constrain and customize their commitments. On one hand, they have strong incentives to become a state party to the ICC. On the other, there is reason to fear that the ICC could become either too weak to cope with trials of politicization or too strong and exceed its own mandate. The extent of the constraining and customizing practice depends upon the states' anticipated possibilities of solving cooperation problems with the ICC. This explains the curious behavior of states towards the ICC. They voluntarily ratified the Rome Statute, but many refuse to cooperate with it.

In developing a measure for state commitment and explaining varying commitment as a result of the delegation dilemma, the study makes several contributions to the existing literature. Research focusing on the ICC deals mainly with International Relations 
(IR) International Criminal Law (ICL) and Transitional Justice (T.J). However, they have diverging perspectives on the ICC and different scientific focal points. [R considers the ICC as an international court and looks on states motives to delegate authority to them. ICL mostly sees the ICC as a individual case or as a legal evolution of the international criminal tribunals and reflects its norms, its institutional design or its development. TJ considers the ICC as one of the legal instruments of transitional justice and mostly concentrates on the ICC's effect on peace and reconciliation. Due to the different perspectives on the ICC there emerge some blind spots that will be illuminated by the present work.

It combines legal and political considerations by connecting states' behavior to the legal area and its history. It looks at domestic conditions on states behavior. By means of empirical methods it opens the black box of states parties to the ICC and shows that there are indicators for commitment beyond ratification.

Using the theoretical knowledge of IR, it shows states' motives in a more general way. It shows that democracy as an explanatory factor plays an important role but is not a sufficient condition for states commitment to the ICC. The decisive factors for the comprehensiveness of states commitment to the ICC are the commitments they have made in human rights law and humanitarian law reflecting their general attitude to international law. Seen in this way, e.g. the USA is a less strong outlier as it is commonly presented in the literature. Although it is a democracy, the USA is no state party to the ICC. However, it has only ratified 16 of 25 humanitarian law agreements and only 5 of 18 human rights agreements.

\subsection{Empirical Puzzle: A Commitment is a Commitment is a Comimtment?}

The distinguishing feature of this study and the point of departure from the previous works mentioned above is that the degree of commitment shall not be seen only in light of the ratification of the Rome Statute. The commonly held view is that commitment understood only as ratification is very high. At the time of measurement there were 124 states parties to the Rome Statute (see Figure 1), among them the newest states parties being the State of Palestine and El Salvador

\footnotetext{
${ }^{4}$ Following the convention the sub-discipline is termed as 'International Relations' and its research object as 'international relations'.

${ }^{5}$ For the 'List of States Parties to the Rome Statute (08-2016), see p. 237 Time of measurement is August 2016. Burundi withdrew in October 2017, the Philippines in March 2019, so that the ICC has currently (state of May 2019) again 122 states parties.
} 


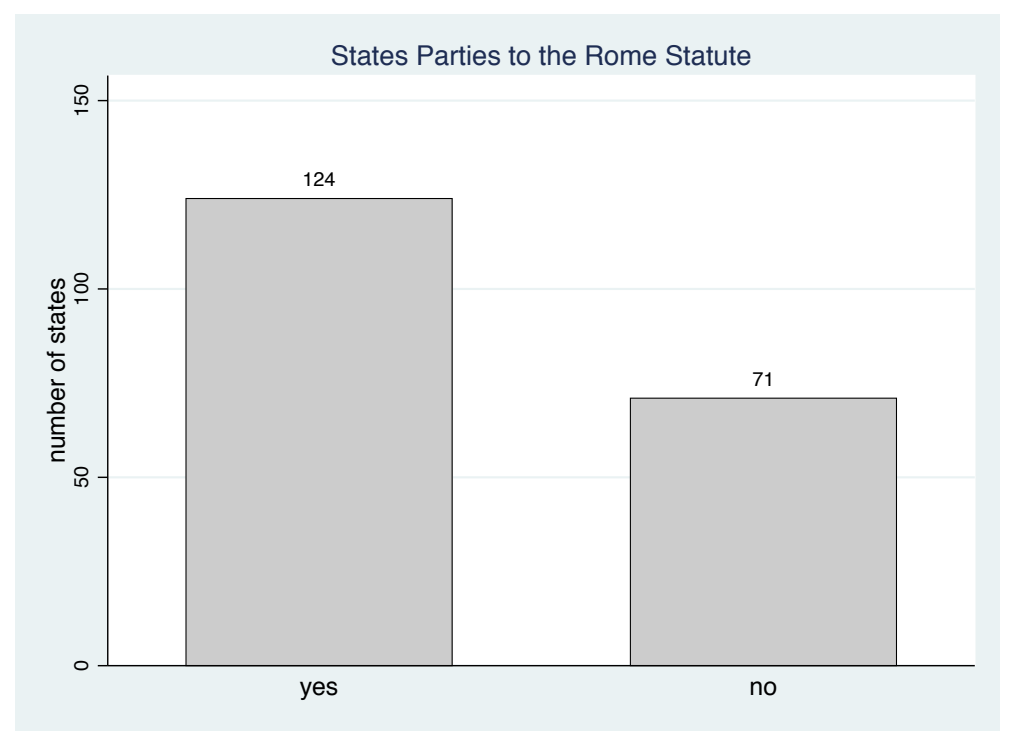

Figure 1: States Parties to the Rome Statute

As to be expected, among the states parties (as of 09/2016) almost all are democracies. There are only 12 democracies that did not ratify the Rome Statute, whereas most of them are small island states, such as Bahamas, Palau, Kiribati or Micronesia. However, there are also three democratic political heavy weights that did not ratify: India, Israel and the United States of America (USA). It is notable that all three of these are strongly involved in international and non-international conflicts. ${ }^{6}$

Likewise, not surprisingly, those which would be affected most by the ICC's investigations and prosecutions did not ratify the Rome Statute. Among the 71 states that are not party to the Rome Statute (see Figure 2) 59 are non-democratid 7 and are key players or scenes of international and non-international conflicts, such as Ethiopia, Thailand, Myanmar, Iran, Iraq, Pakistan, Russia, Somalia, Sudan or Syria, or are particularly repressive, such as China, Egypt, Eritrea, Libya, North Korea, Turkey or Yemen 8

\footnotetext{
${ }^{6}$ Following the Uppsala Conflict Data Program (UCDP "Battle-Related Death Dataset", counting the sum of conflict years per conflict from 2000 to 2015 , Israel has 15 conflict years, USA has 16 and India 75. See: http://ucdp.uu.se/downloads/(29-03-17).

7 The distinction between democratic and non-democratic states follows the Freedom House levels of 2015. Democratic states are those states that are labeled as "free" having a level of 1-2.5 and non-democratic are those that are labeled as "partly free" or "non-free" having a level of 3-7. See: https://freedomhouse.org/report/freedom-world/freedom-world-2016 (28-03-2017).

${ }^{8}$ For an overview of the ratification of democracies and non-democracies see Table 43 on p.238
} 


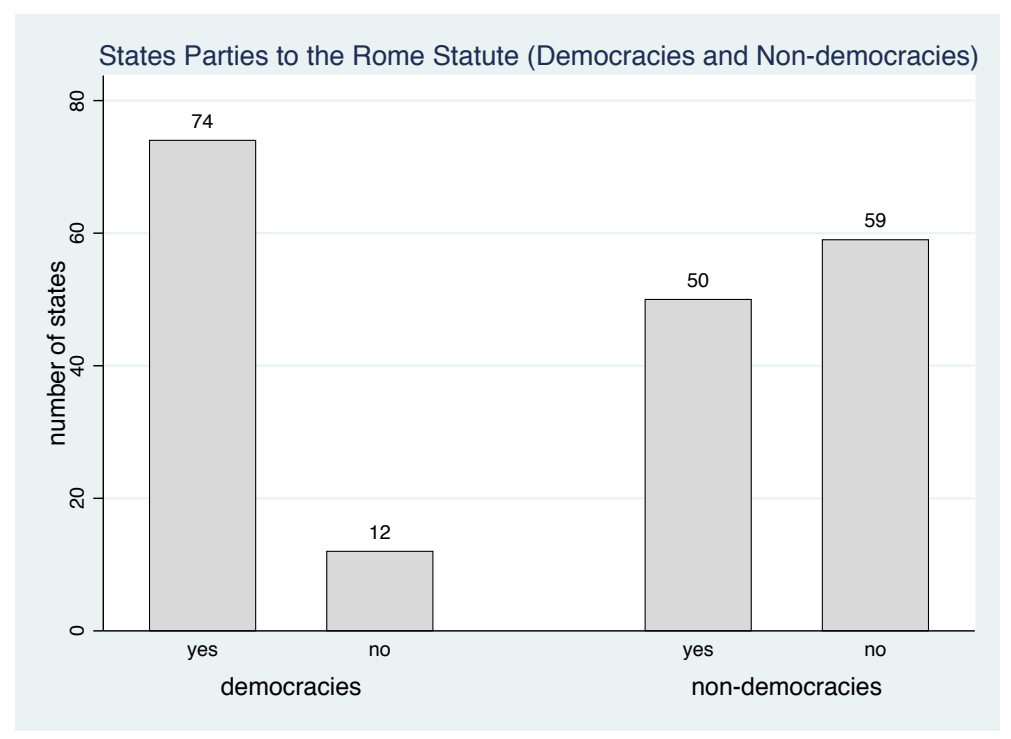

Figure 2: States Parties to the Rome Statute (Democracies and Non-Democracies)

What is even more puzzling is the fact that 50 of 109 non-democratic states ratified and are parties to the Rome Statute. That any state joins an international court can be considered interesting, since such an act requires the delegation of authority (Alter. 2011 Katzenstein 2014). The ICC can be considered to represent a serious intrusion into national sovereignty (Simmons/Danner, 2010), since as a criminal court it is able to prosecute individuals. We can consider sovereignty costs as particularly high, where the relationship between states and their territories as the hallmarks of Westphalian sovereignty is concerned (Abbott/Snidal, 2000, 437).

Non-democratic states' ratification of the Rome Statute can be considered a real conundrum. The fact that non-democracies bind themselves to the ICC cannot be considered as mere cheap talk, a costless signal or window-dressing, as it can lead to investigations and prosecutions. Some of those states, in addition to the states mentioned above, are very repressive, such as Burundi, Bangladesh, Nigeria or Afghanistan. Or they have been in the center of international and non-international conflicts, such as Uganda, Mali, Democratic Republic of the Congo (DRC), Colombia, the Philippines or Chad. While the high degree of commitment can be considered to be a stage win of the court, the ICC struggles with frequent cases of the non-cooperation of its parties. Currently, the ICC pursues investigations and prosecutions in 11 so called "situation[s] 
in which one or more (...) crimes appear to have been committed" (art.13) 9 e.g. in the Democratic Republic of Congo (ICC-01/04) against Thomas Lubanga Dyilo and Bosco Ntaganda because of alleged war crimes and crimes against humanity during the Congo Wars since 2002. Another example took place in Darfur/Sudan (ICC-02/05) against Omar al-Bashir since 2002 due to allegations of genocide by killing and mental harm, both as attacks against soldiers and staff involved in a peacekeeping mission in Darfur; or, in Georgia (ICC-01/15) owing to murder and forcible transfer of population and persecution, as well as intentionally directing attacks against peacekeepers in the context of the international armed conflict in South Ossetia in 2008 10 The ICC also launched preliminary investigations in several other situations, e.g. in Afghanistan in the context of the armed conflict since 2003 between pro- and anti-Government forces; in Iraq/UK because of alleged war crimes committed by nationals of the United Kingdom in the context of the Iraq conflict and occupation from 2003 to 2008; in registered vessels of Comoros, Greece and Cambodia because of the Israeli attack on a Humanitarian Aid Flotilla en route to Gaza Strip in 2010; or, in Ukraine in the context of the suppression of the protest on the Maidan 11

In connection with the investigations and prosecutions as well the preliminary investigations, the ICC struggles with a lack of cooperation and support on the part of the states parties such as in the case of the Sudanese President Omar al-Bashir. Due to genocide, war crimes and crimes against humanity in the region of Darfur since 2001, the ICC issued for the first time against a head of state an international arrest warrant against al-Bashir in 2009. In 2010 the ICC issued a second arrest warrant stressing the need to prevent further atrocities. Nevertheless, al-Bashir was able to move unhindered through Chad and Kenya in 2010, through Djibouti and Malawi in 2011 and South Africa in 2015. All are parties to the ICC (Magliveras, 2013). The ICC-Chief-prosecutor Fatou Bensouda got to the heart of the problems:

"Searching for a head of state is like searching for Al Capone with the polite request he may please surrender himself" (Bensouda, 2014).

Problems of cooperation and support of international criminal courts are not new. Both International Criminal Tribunal for the former Yugoslavia (ICTY) with the

\footnotetext{
9 The ICC distinguishes between 'situations' and 'cases'. A 'situation' is (???). Whereas, 'cases' "comprise specific incidents during which one or more crimes within the jurisdiction of the Court seem to have been committed by one or more identified suspects" (ICC Pre-Trail Chamber I, No. ICC-01/04-101-tEN-Corr, Situation in the Democratic Republic of the Congo, para. 65.).

10 For detailed information on the 'situations under investigation' see https://www.icc-cpi.int/Pages/Situations.aspx (23-07-18).

11 For detailed information on preliminary examinations see the annual 'Report on Preliminary Examination Activities' from the Office of the Prosecutor.
} 
Balkan states and International Criminal Tribunal for Rwanda (ICTR) with the Kigali Government struggled hard for cooperation (Jorda, 2004, 579f.). However, since the ICC is a permanent international court, states parties have to commit themselves to cooperate with the ICC. A case of non-cooperation can be a case of non-compliance with the Rome Statute, making the commitment to the ICC of those states unreliable $[2$

Summing up the puzzle, one can say that there is a high level of commitment to the ICC measured by a high number of ratifications of the Rome Statute, among them many non-democratic states. At the same time, there is a lack of cooperation on behalf of states parties. Being a party to the ICC, does not reveal much about the cooperation and assistance behavior of the states during its investigations and prosecutions. Considered empirically, the commitments to the ICC are not equally strong and raises the RESEARCH QUESTIONS:

1) How strong is the Commitment of States to the ICC Beyond the Ratification of the Rome Statute?

2) What explains the States' eXtent of COMPRehensive Commitment to the ICC?

\subsection{State of the Art and Research Gaps: Black Box States Parties}

In the research literature of political science and international law commitment to an international agreement is usually understood as those acts of states binding themselves through ratification $[3$ by which the respective international norms are recognized, states allow themselves, at least in part, to be subjected to their legal validity or even delegate away sovereignty to an international institution and expressing the willingness for a certain future behavior.

In IR there are plenty of theoretical considerations as to why states bind themselves to international law, particularly to human rights. These range from being only cheap talk in order to increase power and security (Waltz, 1979) and strengthen the hegemonic position in international relations (Koskenniemi, 2004), to reduction of transaction costs

12 Part IX (art. 86-102) of the Statute of Rome covers the rules on "International cooperation and judicial assistance". The obligation to cooperate results of article 86 ICC: "States Parties shall, in accordance with the provisions of this Statute, cooperate fully with the Court in its investigation and prosecution of crimes within the jurisdiction of the Court.". There is an obligation to establish national procedure for these cooperation (art.88 ICC): "States Parties shall ensure that there are procedures available under their national law for all of the forms of cooperation which are specified under this Part."

13 For better clarity and readability in accordance with the conventions of international relations and international law, 'ratification' will be used as a blanket term for all acts of a state binding to an international agreement according to article 11 Vienna Convention on the Law of Treaties VCLT and thus including acceptance, approval or accession of a treaty. 
and increasing their credibility as a more trustworthy partner in international trade and politics (Keohane, 1984a; Abbott/Snidal, 2000) and to signal reliability towards the domestic and transnational civil society locking-in democracy (Helfer/Slaughter. 1997. Moravcsik, 2000) up to being a matter of norms and beliefs (Keck/Sikkink, 1998. Sikkink, 2011; Goodman/Jinks, 2013.

Many ask why states create international courts and tribunals and delegate authority to them although this means a serious intrusion into their sovereignty. This covers a spectrum ranging from expressing power interest s(Steinberg, 2002, Posner/Yoo, 2005a, Koskenniemi, 2011) over being credible commitment devices (Alter. 2004 Helfer/Slaughter 2005), solving cooperation problems (Koremenos, 2007) up to being a result of discourse and persuasion of cosmopolitan norms (Deitelhoff, 2009 Sikkink, 2011).

Nevertheless, there are comparatively few empirical studies that test the theoretical arguments on committing to international courts in general or the ICC particularly (Simmons/Danner, 2010). Those that do exist provide valuable, often unexpected insights in states behavior patterns, such as choosing the degree of judicialization of international dispute settlement dependent on the complexity of the cooperation problems to be solved (Koremenos, 2007), or non-democracies ratifying the RomeStatute dependent on their experienced recent violence and the strength of their rule of law and thus needing support in dealing with the past (Simmons/Danner, 2010).

The present work tries to fill in two main research gaps. Almost all theoretical approaches and empirical studies up until now consider commitment only on the basis of ratification status. Thus, they haven't measured or mentioned qualitative differences of commitment within the group of states that have ratified an agreement. States seem to have only two characteristics: being state party to the ICC or not. This binary assumes there would be an alleged homogeneous group of states parties, which provides no clues for differences among the commitments of states parties. This is the first sign of diverging cooperation behavior to the ICC. Instead the group of states that ratified the Rome Statute seem to be a black box and one has to be puzzled as to why some of them do not cooperate fully with the ICC while others do.

Secondly, the theoretical reflections on the creation of international courts and tribunals allege that all states have more or less the same incentives in delegating authority to international courts and tribunals; notwithstanding the legal area of the court or their domestic political situation. Rather they consider the task of the respective court being sufficient to delegate regardless of their own interests. There are different incentives for Afghanistan, Germany or the USA to commit to the ICC. 
As an aftereffect, there is often no distinction of the states' interests towards a certain legal area with and without a court. Rather, there are identified similar factors for commitment to international law and delegation to international courts. There is hardly any systematic research on diverging incentives of states due to the respective international law that shall be enforced by the court.

We can assume there are major differences in the incentives of states' delegation in terms of trade law compared to terms of human rights or humanitarian law. In the area of humanitarian law the most import enforcement mechanism is reciprocity. But, in the area of human rights there are only weak self-enforcing mechanism. The underlying reason for this is that are different actor constellations. In terms of humanitarian law and human rights. In the area of humanitarian law states are confronted with one another. In the area of human rights the central relationship revolves around the states and their own respective citizens. Therefore, establishing an international court that is able to improve the enforcement of human rights makes a crucial difference for the legal area. Further, it provides a real change in the political incentive structure to stay in compliance with human rights. Thus, we can expect states to behave in a different manner if a new court is established.

The present work attempts to reconcile the two described research gaps of [IR] It aims to conceptualize a broader understanding of commitment to this ICC, beyond the ratification of the Rome Statute as founding treaty. It theorizes and measures variation within the group of states parties and thus opens the black box of states parties to the ICC. Moreover, the different extents of commitment to the ICC will be traced to the inherent logic of incentives that lead them to bind themselves to international criminal law. It will be shown that divergent motivations to delegate authority to the ICC are dependent upon the commitment the states have already made relating to humanitarian law and human rights as being the underlying norms in the background of the Rome Statute. It will be illustrated that there is a clear difference in the delegation logic of states if there is a court or not.

Hence, it becomes apparent that although it is democracies that shows a higher probability of ratifying the ICC it is democracies that also have a high probability of qualifying their commitments. This might explain why even states parties to the ICC do not support the court unconditionally. The states behavior to the ICC depends on their possibility of solving cooperation problems of international law. 


\subsection{Delegation Dilemma and Constrained and Customized Commitments}

As a consequence of the benefits and risks of becoming a state party to the ICC the states get caught in the DELEGATION DILEMMA OF BELONGING TO ICC. Not to become a state party would mean refraining from co-designing the ICC, getting support in dealing with the past, solving cooperation problems of international relations and waiving support in improving freedom and security. However, to become a state party to the ICC would mean the risk of weakening itself, exposing themselves to the danger of suffering from strategical disadvantages towards states that are not party or that spoil the ICC. As a result they then have an increased need of protecting their freedom and security. Although the ICC was established to solve cooperation of international law, it creates some new cooperation problems and the states get caught in a decision dilemma in face of their self-binding to the court.

It will be argued that the extent of constraining and customizing commitments towards the ICC depends upon the states' possibilities to solve cooperation problems with the court. Firstly, though there are high rates of ratification of humanitarian law, human rights or sometimes even international criminal law, it is never a certainty as to who will comply with them and who not. If states want information on this, they must pay high costs for monitoring norm compliance. Particularly as the existing monitoring regime is divers, decentralized and fragmented (Egle, 2016). Investing in monitoring norm compliance with the most severe human rights for western democracies such as Germany would mean portfolio investing in several institutions and organizations such as the United Nations Organization (UNO), European Union (EU), the European Court of Human Rights (ECHR), international criminal tribunals, non-governmental organizations and several more.

Secondly, in a landscape of empty promises und uncertain compliance it is not only difficult to know how the other states behave but it is also difficult for states to signal to others, both on the international and the domestic level, that they are willing to comply. How can transitional states or new democracies signal that they have the will to comply? The establishment of a court such as the ICC makes it possible to reduce the costs of monitoring norm compliance, as there is one centralized institution that has the capability to punish. This can lead to an immense reduction of monitoring costs for certain states that before supported even several monitoring institutions, such as the International Court of Justice or regional bodies. Moreover, the ratification of such 
a strong institution with a high risk of subjecting themselves to the same punishment can be a credible signal to international and domestic actors.

How is this possible? The ICC is not considered a court of human rights! It is a criminal court that shall prosecutes violations of international criminal law in order to cope with a violent past and to promote peace and reconciliation. The argument that the ICC solves cooperation problem with respect to humanitarian law and human rights is based on the fact that although the ICC, founded in 1998, is a comparatively new court, the norms behind the core crimes of the Rome Statute - genocide, crimes against humanity (art. 7), war crimes (art. 8) and the crime of aggression (art. 5, para.1(a) and art. 8 bis) - are much older, based on humanitarian law and human rights.

According to the International Committee of the Red Cross (ICRC) 'humanitarian law' is defined as:

"a set of rules which seek, for humanitarian reasons, to limit the effects of armed conflict. It protects persons who are not or are no longer participating in the hostilities and restricts the means and methods of warfare. International humanitarian law is also known as the law of war or the law of armed conflict"14

Humanitarian law is covered by several treaties such as the Hague Conventions of 1899 and 1907 including the "Annex on Laws and Customs of War on Land" or the the Geneva Conventions of 1949 on the protection of persons not or no longer taking part in hostilities, such as civilians, injured combatants or prisoners.

Human Rights as concept is embodied later, after the atrocities of World War II, in the "Universal Declaration of Human Rights (UDHR)" of (1948). While humanitarian law can be considered as 'charity' in war, human rights have the aim to secure peace. Both do have in common the aim of preserving human dignity. From today's view, humanitarian law can be considered as lex specialis of human rights, nevertheless they are describing two areas of international law (Oberleitner, 2013). Norms of international criminal law as embodied in the "Convention on the Prevention and Punishment of the Crime of Genocide" (1948), the crime against humanity defined by the work of the International Military Tribunal at Nuremberg (IIMT) and the International Military Tribunal for the Far East (IMTFE), the crime of aggression in the ius ad bellum, have made it possible to punish these violations.

The ICC can be considered as a tool to indirectly prosecute some of the negative obligations of humanitarian law and human rights law within the framework of the four core crimes: genocide, crimes against humanity, war crimes and the crime of aggression.

14 ICRC 2014: https://www.icrc.org/en/document/what-international-humanitarian-law (01-08-2018). 
The ICC provides a chance for ending impunity for violations of humanitarian law and human rights law. Therefore, commitment to the ICC depends on commitments to humanitarian law and human rights law that states have already made. The court reduces costs of monitoring human rights and humanitarian law. Additionally, it enhances the credibility of states' commitments. By this way, the court helps the states to solve cooperation problems of international law that arise in the landscape of sovereign states that have to cope with the existence of international law without a world government as an anchor.

However, the question remains open as to why states, nevertheless, constrain and customize their commitments to the ICC? In the present work it will be argued that states are caught in a Delegation Dilemma to the ICC. On one hand there are several reasons for states to become a state party to the ICC. States enjoy the privileges of being a member of the Assembly of States Parties to the ICC (ASP), e.g. (re)negotiating future legislation, deciding on budget or electing judges and the chief-prosecutor. For transitional states and new democracies, it is a chance to cope with the past and to strengthen peace and democracy. Moreover, the ICC offers the chance to solve cooperation problems of international relations.

Notwithstanding those benefits, there are also several reasons for states to be cautious towards the ICC. Since the court is independent and headed by its own states parties, it is missing institutional counterparts (Tomuschat, 2010). There are overlapping executive responsibilities of the Assembly of States Parties to the ICC (ASP), the United Nations Security Council (UNSC) and the states as individual actors. This can lead to a certain fear of the states that the ICC would be too weak to cope with power ambitions of individuals states or so strong that it overstretches its mandate and undermines the principle of complementarity. The states are aware of the fact that other states do have diverging interests and preferences to the ICC. The states parties are still in a state of uncertainty about the behavior of the other states. As the states have different interest structures and as the states know that the others also have different interest structures, they are kept in a state of uncertainty about the behavior of the others.

As a result, they are caught in the DELEGATION DILEMma to THE ICC in which both ratifying and non-ratifying states bear high risks. In order to solve this dilemma states ratify the Rome Statute and become state party to the ICC, but they constrain and customize their commitments to the ICC to retain a certain room for political 
maneuver 15 Thereby, the extent of customization is dependent on both the degree they have committed to humanitarian law and human rights as well as being dependent on whether they would benefit from a reduction of costs of monitoring humanitarian law and human rights that would have otherwise occurred in the absence of the ICC. Seen in this way, the negative attitude of some states towards the ICC (with the USA as a prominent example, and as democracy also as supposed most puzzling example) is not surprising, but rather obvious, since the ICC is has been given great power.

\subsection{Research Design: Building an Index and Testing Determinants}

Making those theoretical arguments testable in an empirical analysis, the present study uses a two-step y-centered research design measuring and explaining the states' comprehensiveness of commitments to the ICC. In the first methodical step, THE InDEX of Commitment to the ICC, will be suggested as measuring device for a comprehensive commitment to the court. This is done to demonstrate different aspects of commitment and to map variation within the states. Thus, it is possible to create variation in the states' extent of commitment with the help of ranking them on a scale from 0 (no commitment) to 12 (comprehensive commitment). This allows the states to be categorized into six groups of different levels of commitment to the ICC: COMPREHENsive Commitments (Group 1), Slightly Customized Commitments (Group 2), Customized Commitments (group 3), Strongly Customized Commitments (Group 4), Weak Commitments (Group 5), No or Very Weak COMmitment (GROUP 6). This provides empirical evidence for the concept of constrained and customized commitments and deconstructs the dichotomy of states parties and non-party states to the ICC creating variation in the states' extent of self-binding to the ICC.

In a second methodical step, the explanatory power of the theoretical argument of states' behavior to the ICC dependent on their possibility of reducing costs of monitoring and the increasing their commitments to humanitarian law and human rights law will be tested empirically by means of regression analyses. With an Ordinary Least Squares (OLS) regression the explanatory power of the theoretical argument on the states' positions on the InDEX of COMmitment to THE ICC will be examined controlling for different third variables, such as experiences of repression, armed conflicts

\footnotetext{
15 The theoretical argument of states constraining and customizing their commitments to the ICC dependent on their general interest in increasing the monitoring of humanitarian law and human rights and their individual interest in assessing the consequences of becoming a state party to the ICC ties onto the concept of constrained independence of (Helfer/Slaughter 2005) who argue that states establish independent courts, but afterwards use fine-grained mechanisms to constrain their independence.
} 
or the establishment of institutions dealing with the past. Subsequently, a multiple logistic regression analysis shall be carried out in order to compare the explanatory power (of former commitments and reduction of monitoring costs) for the position on the Index of Commitment to The ICC as dependent variable with the states' ratification of the Rome Statute as dependent variable. This allows for the quantification of the explanatory power of the theoretical argument giving empirical evidence on the states having divergent incentives in solving cooperation problems with the ICC.

\subsection{Scientific and Political Relevance}

The work aims to contribute to the research on commitment behavior of states to human rights and humanitarian law and on delegation of sovereignty to international courts within the debate on judicialization of international politics. In that sense the scientific relevance lies in measuring and explaining state behavior to the ICC beyond the dichotomy of ratifying or not ratifying the Rome Statute. The theoretical arguments will make it possible to reflect on aspects of constraining the independence of international courts on the part of the states. With the Index of Commitment to THE ICC, an empirical measurement is provided that makes its possible to examine commitment to the court for a high number of states. The index may be in principal transferable in the measurement of all international courts and tribunal with the functions of monitoring and enforcement. This will also provide information pertinent to future research agenda in comparing states commitment and compliance behavior to legal regimes with and without international courts in order to measure the benefit of enforcement mechanisms due to the law that shall be enforced.

Furthermore, there is a high political relevance. The present work shows that it is - contrary to what is commonly believed - theoretically arguable and empirically verifiable that states do have incentives for becoming state party to the ICC due to their opportunity of solving cooperation problems. The Index of Commitment allows us to appraise the actual strength of self-binding more precisely and thereby provides better orientation in assessing future compliance behavior in the shape of both compliance with the core crimes and cooperation with the ICC as an institution. This can also be understood as appeal to monitor the binding behavior of the states parties to the ICC more closely. An evaluation of comprehensive commitment on a regular basis, e.g. through an annual reporting procedure of political and legal experts would make it possible to measure the current level of commitment and to map the development of commitment over time. Thus, we could assign changes of commitments 
to changes of politics. This could function to nudge the states towards improvements in their commitments to the ICC to maintain their credibility.

\subsection{Structure of the Work}

The study proceeds as follows: In CHAPTER 2, FOLLOWING UNIVERSAL NORMS OR MAKING RATIONAL DECISIONS? STATES' COMMITMENT TO INTERNATIONAL LAW AND COURTS IN RESEARCH LITERATURE light will be shed on the theories and empirical studies on the states behavior towards international law and international courts in the literature of IIR. International Law (IL) and ICD An overview is given on theories and explanatory approaches explaining commitment to international law in general and humanitarian law and human rights in particular (2.1). Additionally, an overview is provided as to why states delegate authority to international courts and tribunals although this means a serious intrusion into their sovereignty dependent of their lack of compliance or compensation for said lack of compliance (2.2). Finally, an overview will be on the research gaps and it will be argued in what way the present work is able to close them (2.3).

In Chapter 3, Theory of StaTes' Constraining and Customizing COMMITMENTS TO THE ICC, the theoretical argument on states constraining and customizing commitments dependent on their possibility of solving cooperation problems will be set out. For this purpose, the role of the ICC as guardian of humanitarian law and human rights (3.1) and the benefits of ratifying the Rome Statute to become a state party to the ICC will be illustrated (3.2). Afterwards, it will be highlighted why the states have to fear the ICC to some extent, since it is a stand-alone court and thus missing institutional counterparts in international relations and there is reason to be concerned on a politicization and/or a legal overstretching of the ICC (3.3). It will be shown why this means that some states get caught in a decision dilemma to the ICC vacillating between the options of ratification and non-ratification. Moreover, it will be shown how the dilemma can be solved through constraining or customizing their commitment (3.4) and why the extent of constraining and customizing depends on the possibility of the states solving cooperation problems of international relations (3.5).

In CHAPTER 4, AN INDEX AS SUMMARY MEASUREMENT FOR COMPREHENSIVE COMMITMENT, evidences for the assumption that states customize and constrain their commitments to the ICC is given. Therefore, the possible ways of states constraining and customizing their commitments will be modeled (4.1), data set and methods of data collection and analysis will be set out (4.2). Finally, the results of the Index of 
Commitment to the ICC will be presented thereby illustrating variation in the states' extent of commitment to the ICC (4.3).

In Chapter 5, TeSTING THE EXPLANATORY POWER OF SOLVING INTERNATIONAL COOPERATION PROBLEMS WITH THE ICC the explanatory power of the states' incentives due to their possibilities of solving cooperation problems of international relations will be examined by means of regression analysis. The possibilities of solving cooperation problems by reducing costs of monitoring and enhancing credibility of commitments to humanitarian law and human right will be modeled (5.1). The data set and methods for data collection and data analyses will be set out (5.2). Finally, the results of the regression analyses will be presented (5.3) giving empirical evidence for the theoretical argument of states ratifying the Rome Statute and constraining and customizing their commitments dependent on the possibilities of solving cooperation problems due to their interest in governing the international community and due to their attitude towards humanitarian law and human rights.

In the Chapter 6, Conclusion AND OUTLOOK the theoretical argument and the empirical findings will be summarized (6.1). It will be shown how the index as empirical measurement visualizes the variation in states' behavior to the ICC and expands our knowledge of states behavior towards to international courts in general. It shows that it is worthwhile to evaluate dimensions of states commitments to the ICC more closely and that it is worthwhile to monitor the states' behavior in order to nudge them towards compliance with the ICC (6.2). Furthermore, the limits of the empirical results will be highlighted and several proposed avenues for future research will be derived from the present (6.3). Finally, why the states behavior of constraining and customizing commitments can nevertheless lead to strong bonds to the ICC and a promotion of international judicialization will be discussed (6.4). 


\section{Following Universal Norms or Making Rational Decisions? States' Commitment to International Law and Courts in Research Literature}

Particularly, in the last two decades, we find numerous theoretical arguments and studies in the research literature of [R] dealing with states' behavior towards international law. Both 'legalization of international relations' and the 'proliferation of courts and tribunals' have evolved into their own research areas that are addressed by scholars of $\mathbb{I R}$ and $\mathbb{I}$. In the case of the ICC there are scholars of the $\mathbb{L C L}$ that approach the topic in the context of international criminal tribunals and political questions of why states accept their jurisdiction or why they cooperate with the courts.

The most important questions include: why states commit themselves to international law and why they comply with it. The answers to these questions are as various as they are numerous and range from their own as well as external persuasion to adapt to universal norms. There are only a few studies that focus directly on the motives for states ratifying the Rome Statute of the ICC. In this respect light will be shed on international courts in general as well as international criminal courts and tribunals as subsets.

It is surprising that such a large research gap exists regarding this subject matter. There are hardly any works that differentiate between states' behavior to international law dependent on the existence or non-existence of an international court monitoring the compliance with the law or enforcement of it. This is so notwithstanding the fact that it is one important task of the court to promote change in the compliance behavior of states. Most of the studies consider either mechanisms of compliance with international law as a general phenomenon or delegation of authority to international courts and tribunals in the context of delegating authority to international organizations. We can argue that the viewpoints are coming from different scientific areas and therefore their views overlap one another, but at the same time create a huge blind spot that leaves the question open as to what differences exist in the compliance behavior of states if there is a court or in the absence of a court. Existing literature often identifies similar factors for both commitment to international law and delegation to international courts. In addition to which there is often no distinction between different types of international courts or different areas of international law.

On the empirical level, states parties to an international court such as the ICC are considered as black box. It has been assumed that states would have all the same 
incentives to delegate authority and to submit themselves to a specific international court. Many studies follow the premise of states as a homogeneous group having all the same motives behaving in a certain way towards international courts in general or the ICC in particular. States parties and non-party states to the international courts are often considered as monolithic blocks under the assumption that there is only one possible motive to submit to the court that states can share or not, e.g. to promote peace with the ICC. As a result, there are missing theoretical assumptions of an actor-centered perspective showing the benefits and risks of committing to the ICC dependent on who you are and what you want as a state. This now provides an opportunity to examine different levels of commitment and different states' incentives empirically.

To illustrate this blind spot, in the following chapter it will be shown how the states' behavior towards international law and international courts is explained in the view of IR theory as well as in the interdisciplinary dialogue with IL and ICL. Human rights law and humanitarian law are the most important sources for the core crimes of the ICC and thus particular attention will be paid to the legal area of human rights. It will be differentiated systematically between commitment to and compliance with and the role of international courts having been established in order to strengthen states' compliance with international law.

First, it will be shown how states' commitment to international law is explained in research literature (2.1). The problem of anarchy in international relation will be briefly sketched and different theoretical approaches on commitment to law will be outlined. Moreover, it will be shown whether empirical studies exist that tested the theoretical arguments. Afterwards, it will be shown why states delegate authority to international courts and tribunals (2.2). The problem of non-compliance with international law will be elucidated and will demonstrate why states create international courts and tribunals and delegate authority to address the problem of non-compliance, even though this results in a serious intrusion into the sovereignty of the states. It will be shown that human rights benefit considerably from the establishment of international courts and tribunals. They have - in comparison to other areas of international law - only weak self-enforcing mechanisms. It is worth mentioning here that severe human rights violations are often committed by states on their own civilians and not by foreign states.

The present study will try to close the research gaps. It develops both a concept of comprehensive commitment and a theoretical argument that explains that the states" behavior to the ICC is dependent on their attitude to human rights law and human- 
itarian law since those can be considered as the basis of the core crimes defined in the Rome Statute. It will be argued that there is a huge difference if international law is protected by international courts that have been entrusted with the ongoing care and maintenance of international law. Their effect is especially strong in the field of human rights as there are hardly any mechanisms for self-enforcement. Moreover, with the Index of Commitment to The ICC as an empirical instrument will be developed for the purpose of opening the black box of states parties to the ICC. This allows for a better understanding of different levels of commitment, beyond mere ratification, showing that states constraint and customization of their commitments are dependent upon the benefits of solving cooperation problems in international relations. This offers an actor-centered perspective on states behavior to international courts.

\subsection{Commitment to International Law}

\subsubsection{The Problem of Anarchy in International Relations}

Paradoxically, both international law and international courts are situated in an anarchistic landscape of international relations where there is no world government. In case of the ICC not even an international organization exists to ensure the enforcement of international law. Therefore, it is helpful to have a look at the problems of this anarchistic landscape in international relations.

Why do states cooperate under these conditions of anarchy: ${ }^{16}$ The replies are manifold and range from striving for power (Mearsheimer, 1995) and security (Waltz, 1959) over solving prisoner's dilemma of anarchy through increasing of predictability and trust with international institutions (Keohane/Nye, 1977; Keohane, 1984a; Oye, 1986) to common foreign interests and preferences (Putnam, 1988, Moravcsik, 1997) or common norms and believes (Wendt, 1992 , Katzenstein, 1996, Risse, 2000).

For this reason, international law is considered as a form of cooperation in international relations that has continuously grown in recent years. The /acUNTS currently lists about 3,000 multilateral treaties and approximately 55,000 bilateral treaties along global issue areas like security, economy, environment or referring to common global territories like oceans, airspace or outer space 17

\footnotetext{
16 Dickinson (1926) introduced the concept of 'international anarchy' after World War I in order to describe the state of international relations in which there is no supranational power that would be able to set limits to conflicts between states and to be able to enforce global rules. For further explanations see e.g. Diez et al. (2011, 1ff.).

17 See UN Treaty Collection: https://treaties.un.org/Pages/MSDatabase.aspx?clang=_en (07-12-2016).
} 
In the context of the growing debate in $\llbracket$ and $\amalg$ on the process of legalization of international politics these are described as uneven legalization (Abbott et al. 2000), institutionalized asymmetry (Zangl/Zürn, 2004), interlegal fragmentation (Teubner. 2005. Fischer-Lescano/Teubner, 2007), global legal pluralism (Berman, 2007) disorder of normative orders (Walker, 2008) or stratified multi-level system (Zürn, 2011) 18 Thereby, one of the key issues is: "Why and when do states choose legalized institutional forms when their autonomy would be less constrained by avoiding legalization?" (Goldstein et al. 2000, 391) 19

\subsubsection{Theories on States' Commitment to International Law}

In order to better understand why states commit to the Rome Statute of the ICC we have to answer the general question why states commit to international law understanding both the general and the specific incentives to bind themselves to such a strong institution although this means a serious intrusion into their sovereignty (Simmons/Danner, 2010, Katzenstein, 2014) as illustrated in the introduction of this work. Replying on this pivotal question we find several theses and arguments along the different strands of IR theory; ranging from strengthening power and security over expressing interests in international relations and promoting democratization up to and including being a result of norms and beliefs. These assumptions and arguments shall be briefly illustrated below.

States only commit to international law if it strengthens their power and security. In the view of realism and neorealism law is considered being only an epiphenomenon (Morgenthau, 1948), cheap talk (Waltz, 1979) or an obstacle for protecting the own

18 An overview on the interdisciplinary dialogue of IR and IL can be found in e.g. Slaughter (1993); Slaughter et al. (1998); Simmons (2007); Dunoff/Pollack (2013) and an overview on IR research on international law can be found in e.g. (Abbott. 1989 Hafner-Burton et al. 2012).

19 While scholars of IR and IL researched for a long time independent from each other, several scholars of both disciplines stressed the need of interdisciplinary research on the role of law in international politics and the unevenness of legalization in a special issue of the political science journal 'International Organization' in 2000. Remarkably, at the birth time of IR as an academic field in 1919 with the establishment of the Woodrow Wilson Chair of International Politics at Aberystwyth University in Wales, IL and IR were still strongly connected and scholars in both disciplines argued that a spread of democracy and international international institutions impeded armed conflicts and power politics in international relations (Slaughter 1993).

However, this common belief ended with the outbreak of World War II and the emerging 'realism' in IR and the conviction that the absence of international enforcement mechanisms international law is not able to constrain the power ambitions of states (Dunoff/Pollack 2013) and international law is an epiphenomenon in international politics (Morgenthau 1948). At the latest, since the end of the Cold War and corresponding to the third wave of democratization (Huntington, 1991), the spread of regional organizations (Solingen, 1998 Katzenstein 2005) and the rising globalization of trade and security international law came again to the fore of IR and IL and triggered inter- and transdisciplinary collaboration. 
power (Mearsheimer, 1995). More recent works claim that states' behavior towards international law depends only on the power interests of the states. Some are of the opinion that increasing reputation through compliance with international law is neither the only nor the best means to reach foreign policy objectives (Keohane/Nye, 1977). Powerful states can benefit from violating international law when national security interests are deemed more important in order to protect against perceived threats (Goldsmith/Posner, 2006). While referring to the World Trade Organization (WTO), Steinberg (2002) argues that powerful states only support international rulemaking organization to push their agenda on the international level. Weak states hope to increase their power, since they can immensely profit by stressing their sovereign equality through international law. He argues that realism in international law is still alive. States are the central actors of international law. They have their own political interests and are endowed with material power that they use to enforce said interests (Steinberg, 2013).

"GATT-WTO decision making rules based on the sovereign equality of states are organized hypocrisy in the procedural context. (...) Trade rounds may be launched by law-based bargaining, but powerful states have dominated agenda setting." (Steinberg $2002,3 6 5 \longdiv { 2 0 }$

Posner (2014) holds the opinion that human rights treaties are often not able to address human rights violations because states fundamentally disagree on how states should govern. Democracies would have no costs committing to human rights law and non-democracies would only commit if they are pressured from democratic states that they are dependent on. Human rights would often hinder economic development or pragmatic decisions that weak or failed states must make. In this case human rights enforcement would cause more harm than good. He considers human rights proliferation as "kind of rule naiveté (...) the view that the good in every country can be reduced to a set of rules that can then be impartially enforced" (Posner, 2014, 7). For many states it would be better to start over again, identifying a small number of specific human rights that have priority over all others in order to create clearer incentives to comply with them. He argues that the rule naiveté is responsible for the proliferation of human rights, but conversely reasons why they cannot be enforced. Moyn (2014 81f.) even purports that human rights are only a bad replacement for a real universalism.

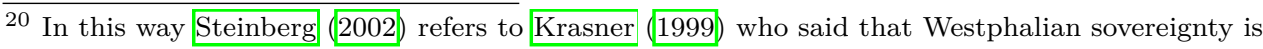
'organized hypocrisy'. 
"The roots of contemporary human rights are not to be found were pundits and professors have longed to find them: neither in Greek philosophy nor monotheistic religion, neither in European natural law nor early modern revolutions, neither in horror against American slavery nor Hitler's Judeocide. (...) Human rights came to the world in a sort of gestalt switch: a cause that had once lacked partisans suddenly attracted them in droves. While accident played a role in this transformation, as it does in all human events, what mattered most was the collapse of universalistic schemes and the construction of human rights as a persuasive, 'moral' alternative to them."

Likewise, albeit skeptical, but more normative are critical legal studies that argue that international law would be a tool for hegemonic power. Those emerged as criticism of liberal theory and use assumption and methods of Critical Theory to analyze power structures within international law (Purvis, 1991). However, they also criticize realism for having no normative claims (Koskenniemi, 2011, 89ff.). They argue that international law offers an opportunity to express hegemonic claims with legal rhetoric. Humanitarian intervention being one example of this.

\begin{abstract}
"Law's contribution to security is not in the substantive responses it gives, but in the process of justification that it imports into institutional policy and in its assumption of responsibility for the policies chosen. Entering the legal culture compels a move away from one's idiosyncratic interests and preferences by insisting on their justification in terms of the historical practices and proclaimed standards of community." Koskenniemi. 2011. 100)
\end{abstract}

Similarly, there are voices of postcolonial theory arguing that the proliferation of international law in general and human rights in special is a form of cultural relativism ignoring views and need in different cultural communities (Dhawan, 2014).

\footnotetext{
"Critical advocates of human rights in the postcolonial era (...) reject imperial universalism, which categorizes culturally specific understandings of morality as 'savage' and 'anti-modern' (...). Instead, human rights advocates argue that a minimal core of values should be treated as objectively moral and beyond that moral core, an overarching principle of toleration should be promoted, which recognizes the diversity of cultural practices." (Cowell 2014, 267)
}

Thus, in the approaches that see states driven by power and security the sovereign state is much more highly valued than international relations. Commitment to international law is rather improbable and occurs only if states consider that there is a possibility of increasing their own power in doing so. International law does not lead to more equality, but usually strengthens the fittest and weakens the weakest. 
States commit to international law achieving interests and agenda setting in international relations. Scholars of regime theory brought international institutions to the fore of IR tackling the realist assumptions while still believing in a world of anarchy.

"Regimes can be defined as set of implicit or explicit principles, norms, rules, and decision-making procedures around which actors' expectations converge in a given area of international relations. Principles are beliefs of fact, causation, and rectitude. Norms are standards of behavior defined in terms of rights and obligations. Rules are specific prescriptions and proscriptions for action. Decision-making procedures are prevailing practices for making and implementing collective choice." (Krasner 1983, 2).

'Regimes' are able to capture international law within an established political system, be it formal or informal (Donnelly, 1986) argues that there are different types of international regimes; declaratory, promotional, implementation and enforcement regimes. The international human rights regime includes several bodies promoting the commitment to human rights and monitoring the compliance with human rights law by means of working groups or communication procedures both on the international and on the regional level, such as the Inter-American or the African human rights regimes. While the regime view can be found in neorealism it also can be considered as a starting point for neoliberal institutionalism as the most important alternative to the realist approach. States are here considered as unitary egoistic actors seeking optimal strategies to assert and maximize their own benefits.

One of the central arguments is that states suffer from prisoner's dilemma in international relations. States tend to choose non-cooperation over cooperation, since they cannot be sure how the other side will behave. One-sided cooperation could lead to a comparative advantage for those that defect even though it would have been the best for both to cooperate. Thus, it is a dilemma that reflects the tense relationship between the rationality of groups that have high incentives to cooperate and the rationality of individuals that have high incentives to defect (Axelrod, 1980, 4).

\footnotetext{
"The distinguishing feature of the Prisoner's Dilemma is that in the short run, neither side can benefit itself with a selfish choice enough to make up for the harm done to it from a selfish choice by the other. Thus if both cooperate, both do fairly well. But if one defects while the other cooperates, the defecting side gets the highest payoff, and the cooperating side is the sucker and gets the lowest payoff. This gives both sides an incentive to defect." (Axelrod, 1980, 4)
}

There are several ways to solve the prisoner's dilemma through creating iteration of the game and thus incentives to cooperate in the 'shadow of the future' through the mechanisms of 'tit for tat' and reciprocity (Axelrod, 1984). Negotiating international 
agreements and committing to international law is thereby one possible way, since international law promotes iteration, modifies the payoffs, and thus increases certainty and predictability allowing states to become more likely to cooperate (Abbott, 1989 , 362ff.). Solving the game is possible by finding the Nash Equilibrium. In this circumstance, none of the players has a unilateral incentive to defect because none of the other choices would bring a higher payoff.

Koremenos (2007, 191) is of the opinion that "the law itself must be an equilibrium in a non-cooperative game". In an empirical analysis she showed that about $50 \%$ of all international agreements have dispute settlement provisions. She proved that those agreements that address complex cooperation problems, such as uncertainty or prisoner's dilemma incentives to defect, are very likely to include dispute settlement mechanisms. On the contrary, agreements that address a lesser complex problem are rather unlikely to include dispute settlement provisions and need them less. She argues that international law is most effective if it considers the interests and constraints of the international actors (Koremenos et al. 2001). Thus, if law is the equilibrium in a non-cooperative game, it is self-enforcing and does not need enforcing mechanisms like adjudication. If there are incentives to defect, since the equilibrium is defection, adjudication is useful and probable. Thus, in the view of neoliberal institutionalism, states commit to international law to solve cooperation problems and to create certainty and predictability.

Putnam (1988) explains the commitment to international law with the concept of 'two-level games'. In his opinion, domestic politics shape international politics and vice versa. He refers to the concept of win-sets (Shepsle/Weingast, 1987, 90) that is defined as "the set of alternatives in $\mathrm{x}$ that command majority support over $\mathrm{x}$ ". Relating to international law the win-sets result from all possible agreements on the international level in which a majority on the national level is achievable. The larger the win-sets, the more probable the ratification of international agreements. Thus, failed ratification is not an inevitable result of intentional defection. This makes the mere signature less credible, even though the cost to their reputation may be very high in the event that the governments fail to ratify (Putnam, 1988, 435ff.)

A further important argument of institutionalism is that international law creates legitimacy, reduces transaction and negotiation costs and increases the credibility of commitments (Abbott/Snidal, 2000, 422). International law may solve cooperation problems, such as uncertainty about the behavior of the others, distributions problems, problems of negative externalities or the problem of 'deadlock' in which each player prefers not to cooperate. According to Keohane (1984a) international law makes co- 
operation more likely, since it reduces transaction costs through the definition of the condition for negotiation, improves the quality of information and creates legitimacy. Abbott/Snidal (2000,429) build on this argument stressing that legal commitments can affect actors on the internal as well as the domestic level. Through the creation of legal norms common rules and standards are determined and the future becomes less uncertain, albeit highly dependent upon current political interests and preferences.

"Legalization entails a specific form of discourse, requiring justification and persuasion in terms of applicable rules and pertinent facts, and emphasizing factors such as text, precedents, analogies, and practice. Legal discourse largely disqualifies arguments based solely on interests and preferences." (Abbott/Snidal, 2000 429)

The argument of enhancing credibility builds on Fearon (1997) who developed a theory on strategies of states signaling foreign policy interests. A point of departure from his considerations was - to some extent ironically - the question of how states can make military threats credible to the state threatened. He sees two possibilities of communicating willingness: tying one's own hands or sinking costs to make threats costlier. Tying one's own hands in front of a large domestic or international audience, e.g. by making a public statement, increases the ex-post costs of retraction considerably, whereas sinking costs, e.g. by mobilizing troops or building arms, increases the ex-ante costs. Both strategies enhance credibility, but it is preferable to use the strategy of hand tying because it is less provoking and possibly cheaper. Especially, if there will be no need for military use in the end (Fearon, 1997). The argument was taken up again and again. It twisted from reasons for military threat to reasons for delegating power to international institutions. Moreover, it can be found in the theoretical approaches of liberal theory on international relations and international law.

States commit to international law furthering democracy and global society. Moravcsik/Legro (1999) raise the question: Is anybody still a realist? They argue that realism and neorealism are not able to redress anomalies in international politics, such as states' commitment to international law. Liberal theory can be considered as an alternative view, since it is able to capture domestic interests and preferences. In liberal theory the focus is placed not on the level of states, but rather on the relation between states and civil society, both on the domestic and on the transnational level. Institutionalist theory is criticized because it does not explain changes of regimes, the domestic and transnational relations between individuals and states and, most of all, it is not able to say anything on the importance of the Kantian 'democratic peace' in international relations (Slaughter, 1993, 207ff.). 
Human rights are considered the core of international law, since it not rules the relations between states, but the relations between states and societies, as well.

"From the perspective of Liberal theory, human rights law is the core of international law (...), but from a normative rather than a positive perspective. Many international lawyers and policymakers still see human rights law as an exception to the fundamental proposition of state sovereignty and nonintervention. (...) Yet human rights law is precisely about structuring state-society relations to ensure at least minimal individual flourishing. We can justify that function from a moral perspective; Liberal IR theory would also argue that governments that oppress their citizens are more likely to present a threat to other governments or to the international system." (Slaughter, 2000b, 246)

The argument of growing the audience, signaling interests and enhancing credibility become particularly important in explaining why even repressive states ratify human rights agreements even when they must fear several negative consequences. Seen in his light, it does not only solve cooperation problems, but it is a possibility of lockingin democracy. With recourse to the argument of enhancing credibility, Moravcsik (2000) explains why states establish human rights regimes although they challenge both Westphalian state sovereignty as well as democratic legitimacy and states' selfdetermination.

"Why would any government, democratic or dictatorial, favor establishing an effective independent international authority, the sole purpose of which is to constrain its domestic sovereignty in such an unprecedentedly invasive and overtly nonmajoritarian way?" (Moravcsik 2000, 219)

He is of the opinion that the primary proponents of human rights agreements were neither great powers nor established liberal democracies, but newly emerged democracies.

\footnotetext{
"Although established democracies supported certain human rights declarations, they allied with dictatorships and transitional regimes in opposition to reciprocally binding human rights enforcement - a seldom-noted tendency for which realists and ideational theorists have no explanation. The primary proponents of reciprocally binding human rights obligations were instead the governments of newly established democracies." (Moravcsik 2000, 219f.)
}

He argues that states choose the tactic of enhancing credibility by delegation of sovereignty to an independent international institution when the expected reduction of uncertainty outweighs the expected costs to their sovereignty. In his view new democracies have the greatest interest in protecting the political status against autocratic or repressive threats. 
"This curious pattern is explicable only if we adopt a different theoretical starting point: the domestic political self-interest of national governments. Establishing an international human rights regime is an act of political delegation akin to establishing a domestic court or administrative agency. From a 'republican liberal' perspective - one related to institutional variants of 'democratic peace' theory as well as to the analysis of 'two-level games' and public-choice theories of delegation - creating a quasi-independent judicial body is a tactic used by governments to 'lock in' and consolidate democratic institutions, thereby enhancing their credibility and stability vis-a-vis nondemocratic political threats. In sum, governments turn to international enforcement when an international commitment effectively enforces the policy preferences of a particular government at a particular point in time against future domestic political alternatives." (Moravcsik. 2000 219f.)

In many legal regimes the key actors refuse to commit to international agreements as in the cases of the USA and the International Criminal Court or USA and China and the Kyoto-Regime. Others commit with no intention of complying as in the cases of autocracies and the human rights (Hafner-Burton/Tsutsui, 2005. Simmons, 2009). Moravcsik (2013, 88) states that international law is the regulation of the interstate relations and preferences that define problem structures and potential for cooperation. Thus, in the view of liberalism, states commit to international law in order to strengthen their democracy and their way of behaving democratically in international relations.

"[A] domestic coalition of social interests that 'benefits' (ideally or materially) directly and indirectly from particular regulation of social interdependence is more powerfully represented in decision-making than the countervailing coalition of losers from cooperation. (...) The greater the potential joint gains and the lower the domestic and transnational distributional concerns, the greater the potential for cooperation." (Moravcsik. 2013 , 87f.)

States commit to international law if this corresponds to their norms and believes. The mobilization of domestic and transnational actors promoting the states' commitment to international law in general and to human rights is also an important argument in the theoretical approaches of social constructivism. Human rights stand in the center of this research, since it regulates the relation between states and civil society and strengthens the rights of the individuals. The window dressing behavior of some states pretending to behave properly while doing otherwise is limited by the fact that there are several local and international non-governmental organizations like Amnesty International that record and report human rights violations and make this information available for the global public. 
With the ever-increasing importance of non-state actors and structures of norms not under the states' control, realistic concepts have become outdated (Deitelhoff/Zürn. 2016 194). Approaches of rational institutionalism and liberalism have been tackled. Social constructivism argues that the 'logic of rationality' and cost and benefit considerations states behavior towards international law cannot be explained. An example of this is the norm of universal membership that can be found in many international legal regimes and leads to such idiosyncrasies such as landlocked states becoming members of the United National Convention on the Law of the Sea (UNCLOS). Accordingly, the starting point for considerations is that actors choose institutional designs in a 'logic of appropriateness' (Wendt, 2006, 408).

Many studies in social constructivism are concerned with the proliferation of norms in international relations. When referring to human rights, we can find explanatory approaches as to why states and even non-democratic states commit to human rights. In social constructivism states commit to international norms such as the human rights because they are conform enough to their own norms and beliefs (Chayes/Chayes, 1993). They are based on or create legitimacy (Franck, 1990, Hurd, 1999). Or, the states became persuaded (Deitelhoff, 2006) or are pressured from transnational advocacy networks (Keck/Sikkink, 1998, Finnemore/Sikkink, 1998, Sikkink, 2017), such as a Non-Governmental Organization like Amnesty International (Clark, 2001) or jurist advocacy networks (Alter et al. 2012) like the International Commission of Jurists (Tolley, 1994). The latest studies on social constructivism argue that the power of discourse and persuasion are pivotal (Hawkins, 2004, Deitelhoff, 2009).

Sikkink (2011) developed the term of 'justice cascade' to take into account that international justice and individual criminal accountability spread around the globe. It reached momentum with the Nuremberg and Tokyo trials, Genocide Convention of 1948, Geneva Conventions of 1949, Convention against Torture of 1985, as well as ICTY and ICTR and the domestic and foreign prosecutions in Greece, Portugal and Argentina, the combination of which reinforced universal norms. This reached its peak with the establishment of the ICC. Although all the theoretical approaches on commitment to international law differ strongly in their assumptions and arguments, they do have in common presuming law as results of expression of power and thus considering treaties as mirrors of politics. 


\subsubsection{Empirical Studies on States' Commitment to International Law}

There are numerous empirical studies on states' commitment to international law. Two kinds of studies can be identified as pivotal in the case of human rights research. There are qualitative case studies examining the overall proliferation of human rights in a certain kind of diffusion. As well, there are several quantitative studies examining why states sign and ratify certain international agreements.

Besides, there are plenty of quantitative studies examining ratification of international agreements. Simmons (2009) who examines the ratification of six core human rights treaties ${ }^{21}$. She argues that legislative and political veto-players as well as domestic judicial institutions play an important role for states' decision to ratify human rights treaties. With the help of history analysis and cox proportionate hazard models she shows that risk factors for ratification are e.g. being a democracy, being Christian or having a common law system. Moreover, there are strong regional patterns.

Neumayer (2007), for example, considers commitment not only ratifications, but examines explanations for states making reservations to human rights treaties. He chooses the same six human rights treaties and examines the amount of reservations, understandings and declarations as a dependent variable. With the help of a negative binominal regression analysis he tests the competing hypotheses that liberal democracies set up either a higher number of reservations or a lower number of reservations, understandings and declarations. He concludes that in fact liberal democracies have more reservations, understandings and declarations. Accordingly, he speaks of 'qualified ratifications' of human rights treaties.

Beyond empirical studies on the commitment of international law in general and human rights in particular, there are studies on the compliance with international law or relation to human rights that focus on the gap between commitment and compliance. The following work attracted widespread attention in the research of IR and IL. Hathaway (2002) shows in a regression analysis with time-series data of five issue areas torture, genocide, civil liberty, political representation of women and fair trials - that human rights obligations in the absence of monitoring and enforcement mechanisms are often not fulfilled. Only in very strong democracies can we observe an improvement in compliance with human rights. This can be explained by the existence of domestic

${ }^{21}$ International Covenant on Civil and Political Rights (CCPR); International Covenant on Economic, Social and Cultural Rights [CESCR; ; International Convention on the Elimination of All Forms of Racial Discrimination (CERD; Convention Against Torture and Other Cruel, Inhuman or Degrading Treatment or Punishment [CAT); Convention on the Elimination of All Forms of Discrimination against Women (CEDAW]; and Convention on the Rights of the Child (CRC). For the 'List of Human Rights Treaties' see p.240 
monitoring mechanisms. However, in autocracies that are the main spoilers of human rights, there is often no change in the level of repression after the ratification of human rights treaties. Not only is there no single treaty that can be associated with better human rights practices, there are even several treaties that can be associated with human rights practices that worsened after ratification. A counterintuitive finding, she explains that this negative effect is due to the high-pressure civil actors place on governments.

\footnotetext{
"External pressure on countries to demonstrate a commitment to human rights norms creates strong incentives for countries to engage in favorable expressive behavior by ratifying human rights treaties. But because human rights treaties are generally only minimally monitored and enforced, there is little incentive for ratifying countries to make the costly exchange in actual policy that would be necessary to meet their treaty commitments." (Hathaway, 2002, 2020)
}

Precisely this puzzle drives the research of Hafner-Burton/Tsutsui (2005). They argue in the same manner that in the absence of enforcement mechanisms human rights treaties provide the incentive to circumvent their human rights obligations. It is very attractive for autocratic states to ratify human rights treaties because they have relatively low costs considering missing enforcement mechanisms while they expect high benefits by increasing their international reputation. Moreover, the ratification of human rights treaties by autocratic states can increase the number of human rights violations. With the help of a pooled time-series cross-section regression analysis for 1978-1999 they test their hypotheses for six treaties [CCPR CESCR [CERD [CAT] CEDAW and CRC). They find out that states with a higher level of ratification are not more likely to comply with human rights, but sometimes even less likely. They describe these phenomenon as 'paradox of empty promises', arguing that the ratification of the human rights treaties raises the attention of international and domestic actors of civil society and those, however, consequently put pressure on the states, which in turn results in more human rights violations than before.

Buneo De Mesquita et al. (2005) take up the aspect that democracies tend to have better human rights practices. With the help of ordered logit regression analyses for 1976-2001 they examine which aspects of democracy improve human rights practices. They conclude that being a democracy increases the probability of better human rights practices. Not all dimensions of democracy contribute in the same manner to an improvement in human rights practices, but competition between parties provides positive effects. Additionally, they show that a simple increase of democratization does not inevitably lead to better human rights practices, but rather that particular 
states with very high levels of democracy have better practices. They consider this as an indicator for the fact that attainment of human rights is a long process for states and their citizens.

Neumayer (2005) examines human rights performance operationalized as civil rights practices and personal integrity practices dependent on the ratification of CCPR and its first optional protocol, CAT as well as opt out provision of article 21 and 22 and moreover on several regional human rights treaties, such as European, American, InterAmerican and African provision for human rights protection in general and torture in special. With the help of both fixed-effects and ordered probit regression analyses he examines the explanatory power of the level of ratification to the international and regional treaties. He concludes that it cannot be identified as a simple relationship between ratification and good performance. He confirms Hathaway (2002) with respect to better practices in democracies as well as the potential for a possible worsening in autocracies. Moreover, he confirms Hafner-Burton/Tsutsui (2005) regarding the positive role of civil society in democracies. However, he makes references to findings later published on the role of reservations (Neumayer, 2007) in which he points out that the democracies that seem to be the most willing to comply with the human rights they committed to, will also have the highest incentives to make reservations to articles they do not want to be bound to. 


\subsection{Delegation of Authority to the International Criminal Court}

\subsubsection{The Problem of Non-Compliance with International Law}

To better understand why states delegate authority to the International Criminal Court we must ask why they are willing to delegate to international courts in general. It will be argued that the motive for delegation is dependent on the problem of non-compliance without those court. As shown above, states commit to international law as cheap talk in order to increase power and security (Waltz, 1979, Koskenniemi, 2004), reduce transaction costs and increase their credibility by becoming either a more trustworthy partner in international trade and politics (Keohane, 1984a Abbott/Snidal, 2000) or signaling reliability towards the domestic and transnational civil society 'locking-in democracy' (Helfer/Slaughter, 1997. Moravcsik, 2000); or as matter of norms and beliefs and sometimes even cosmopolitan conviction (Keck/Sikkink. 1998 Sikkink, 2011, Goodman/Jinks, 2013).

Now the crucial question is: Why do states go one step further and not only commit to international law but allow authority to be delegated to international courts and tribunals although this means a serious intrusion into their sovereignty? This puzzling behavior can only be understood looking at the benefits for complying with the international law they committed to. In relation to compliance with international law we can distinguish the incentives for complying with international law along the two mechanisms of self-enforcement and enforcement. Accordingly, there are several different identified conditions and mechanisms in research literature under which states comply with international law: Those include a broad range spanning from international law being congruent with self-interests of geopolitics (Morgenthau, 1948) or security (Waltz, 1979) up to and including the mechanisms of reciprocity (Keohane, 1984a), domestic interests and preferences (Moravcsik, 1997, Milner, 1997), mobilization of domestic groups (Helfer/Slaughter, 1997, Simmons, 2009), and mobilization of nongovernmental organizations (Finnemore/Sikkink, 1998, Keck/Sikkink, 1998; Sikkink, 2011).

While Henkin (1979) optimistically proclaims that "almost all nations observe almost all principles of international law and almost all of their obligations almost all of the time", up to now empirical studies show that states' commitments to human rights are often only costless expressions (Hathaway, 2002) or empty promises (Hafner-Burton/Tsutsui, 2005). There is only empirical evidence that demonstrates that democracies are more likely to show commitments while still leaving open the possibility of making reservations and interpretative declarations (Neumayer, 2007). 
Thus, international enforcement courts are created to fill in the vacuum of voluntary self-commitment to international law and enforcement of international law (Shelton, 2009). Guzman (2008a) is of the view that there are $3 \mathrm{R}$ 's of compliance - reputation, reciprocity and retaliation - that can lead to compliance with international law without enforcement mechanisms.

\footnotetext{
"Reputation can be defined as judgments about an actor's past behavior used to predict future behavior (...). 'Reciprocity' refers to actions, that, like reputation, will often be taken without the intent to sanction a violator. In response to a violation, states may withdraw their own compliance with an international agreement because once the violation takes place the agreement ceases to serve their interests. (...) 'Retaliation' in contrast, describes actions that are costly to the retaliating state and intended to punish the violating party." (Guzman, 2008a 33)
}

The mechanism of retaliation as the oldest among the three, since it is one legitimate way in international law to react to violations of international law with diplomatic, economic or military sanctions. In particular, the UNSC frequently makes use of it. Though the UNSC has a broad authority using sanctions, there is an emerging debate on the limits of sanctions through the rules of humanitarian law, human rights and the law on unilateral sanctions and especially the principle of proportionality constrains coercion and force (O'Connell, 2002).

According to Philippe (2008) in the area of humanitarian law itself, it is often very hard to use sanctions because they are often ineffective due to overlapping competencies between national and international authorities that are also allowed to punish violations of humanitarian law. The establishment of courts and tribunals supersedes the usage of retaliation or sanctions in response to violations of humanitarian law (Cassese, 1998).

The mechanism of reciprocity refers to the approaches of rational institutionalism mentioned above. The institutional framework leads to a repetition of these situations and the actors themselves are less likely to avoid overplaying their hands knowing that the same negotiation or situation may repeat itself again when the shoe is on the other foot (Axelrod, 1984 Keohane, 1984a). In international law there are several legal regimes functioning consistent with the mechanism of reciprocity, such as the WTO that regulates the reduction of tariffs and non-tariff trade barriers or the Law of the Sea that regulates the use of the oceans (Parisi/Ghei, 2003). Moreover, the law of war can be considered as functioning through reciprocity, be it specific or diffuse, since it is a fine line in the legitimate and illegitimate use of weapons when attacking military objectives (Watts, 2009). 
Closely linked is the mechanism of reputation. It can be found in the literature of rational institutionalism, liberalism and even social constructivism. Reputation can make a state a trustworthy partner for cooperation in the future and thus again contribute to solving cooperation problems (Axelrod, 1984 Keohane, 1984a). Moreover, reputation can also be an important signal towards domestic and international actors locking-in democracy (Simmons, 1998, Moravcsik, 2000). Not the least of which, reputation is often the currency states receive by giving into pressure from transnational advocacy networks promoting human rights (Keck/Sikkink, 1998, Finnemore/Sikkink, 1998). On the part of realists there are serious concerns about the mechanism of reputation.Goldsmith/Posner (2006, 88ff.) argue that if law itself must be the equilibrium in a non-cooperative game, we could ask why we need the law anyway. States only commit to or comply with international law if it meets their interests and preferences. Reputation must be put into perspective since one cannot conclude that non-compliance in certain areas of international law must lead to non-compliance in every area. Moreover, non-compliance with international law can also lead to an enhanced reputation within their own political society or with certain political partners. Non-compliance can demonstrate that a state can even protect against threats to national security or show solidarity with a certain political partner although this leads to a violation of international law (Goldsmith/Posner, 2006) ${ }^{22}$

Bueno de Mesquita (2010,359) is of the opinion that although compliance with international law can be an option for establishing reputation one still has to take into consideration that there are different kinds of reputation. States might have a high reputation in general, but we can also expect them to want to enhance their reputation in certain critical areas and outlive their respective term of office. As well, Downs/Jones (2002) argue that through non-compliance the states' reliability only decreases relating to agreements with similar fluctuating reputation costs.

Locating the mechanisms of compliance within the IR theories, we will find 'retaliation' in approaches of realism and neorealism, 'reciprocity' in approaches of neoliberal insti-

\footnotetext{
22 They explain the difference as follows: "To understand the difference between the reputation story and the retaliation story, consider the case of sovereign dept. Suppose state B borrows money from state A and then defaults on the loan. The retaliation story implies that state B will be punished, if at all, by state A. State A may retaliate by cutting of trade, or taking military action, or simply refusing to lend to state B in the future, even though the loan in the future might seen profitable. No other state will punish state B. The reputation story implies that state A, and all other states, will update their belief about the likelihood that B would repay any future loans, and in the future they will refuse to lend to B (or lend at a higher interest rate) because B is now a higher risk. Lending is no longer attractive because it is too risky and thus less profitable. Indeed, states might conclude that B is untrustworthy in a range of possible cooperative relationships, including military alliances and trade." (Goldsmith/Posner. 2006 101f.)
} 
tutionalism and 'reputation' in both neoliberal institutionalism and (neo-)liberalism. Involving the arguments of social constructivism, we can add 'internalization" (Cohen, 2009) and 'persuasion' as fourth and fifth mechanism of state compliance with international law (see table $12^{23}$

Why is it a vital point to understand why states delegate such authority to international courts and tribunals? In sum, it can be argued that compliance with international law is at its worst when sanctions and self-enforcement mechanisms, such as reciprocity or reputation, are not available (Scott, 2003). Compliance with humanitarian law works reasonably well because of the mechanisms of retaliation and reciprocity (Watts, 2009). Compliance with human rights law is less likely, as it is the area of international law that is affected most by a lack of self-enforcing or self-enforcement mechanisms.

Human rights are fundamentally different than the usual forms of international cooperation or common norms of international law. For example, they are not designed to regulate externalities in the issue area of trade or environment. They are designed to hold states accountable for domestic activities (Moravcsik, 2000) and they do not follow the logic of reciprocity as humanitarian law does, since they mainly affect the relationship between a state and its citizens. This means that other states often have no incentives to intervene until a certain level of human rights violations has been reached. As a result, the violating states have less reason to justify their behavior than they would have in areas of international law that regulate interaction between states. Accordingly, as shown in Figure 3 there is still a huge 'gap between commitment and compliance' (Simmons/Danner. 2010) and many commitments of human rights agreements remain 'empty promises' Hafner-Burton/Tsutsui, 2005).

Both commitment to human rights law and compliance with them are harder to reach than in other legal areas. Human rights suffer from the gap between commitment and compliance. This can be explained by strategic ratification. Autocracies try to perform a form of social camouflage on the global public stage knowing full well there are few possibilities of getting sanctioned for bad human rights practices (Simmons, 2009 ).

23 This overview of compliance mechanisms is neither complete nor exhaustive, but shall provide an orientation in the lines of argumentation in IR-theory. For further explanations of IR-theory see on arguments of neorealism (Steinberg, 2013); rational-choice (Guzman 2008a); liberalism (Slaughter, 1993) or social constructivism (Wendt 2006 Cohen| 2009). 


\begin{tabular}{|c|c|c|c|}
\hline $\begin{array}{l}\text { MECHANISM of } \\
\text { CoMPLIANCE }\end{array}$ & $\begin{array}{l}\text { ProbaBiLITY of } \\
\text { SELF-ENFORCEMENT }\end{array}$ & IR-THEORY & EXPLANATORY APPROACHES (SELECTION) \\
\hline retaliation & high, but conflictual & realism, neorealism & Waltz (1959); Mearsheimer (1995] \\
\hline reciprocity & high, but minilateral & neoliberal institutionalism & Axelrod (1984); Keohane (1984b), \\
\hline reputation & low for humanitarian law and human rights & neoliberal institutionalism & Downs/Jones 2002); Guzman 2008a, \\
\hline reputation & low for humanitarian law and human rights & liberalism & Moravcsik (2000); Slaughter (2000b); Simmons 2009] \\
\hline reputation & low for humanitarian law and human rights & social constructivism & Keck/Sikkink (1998]; Finnemore/Sikkink (1998, \\
\hline persuasion & high, but limited on small group & social constructivism & Hawkins 2004]; Deitelhoff 2009] \\
\hline internalization & high, but limited on few & social constructivism & Koh (1997]; Goodman/Jinks (2013. \\
\hline
\end{tabular}

Table 1: Probability of Self-Enforcement Due to Compliance Mechanisms 


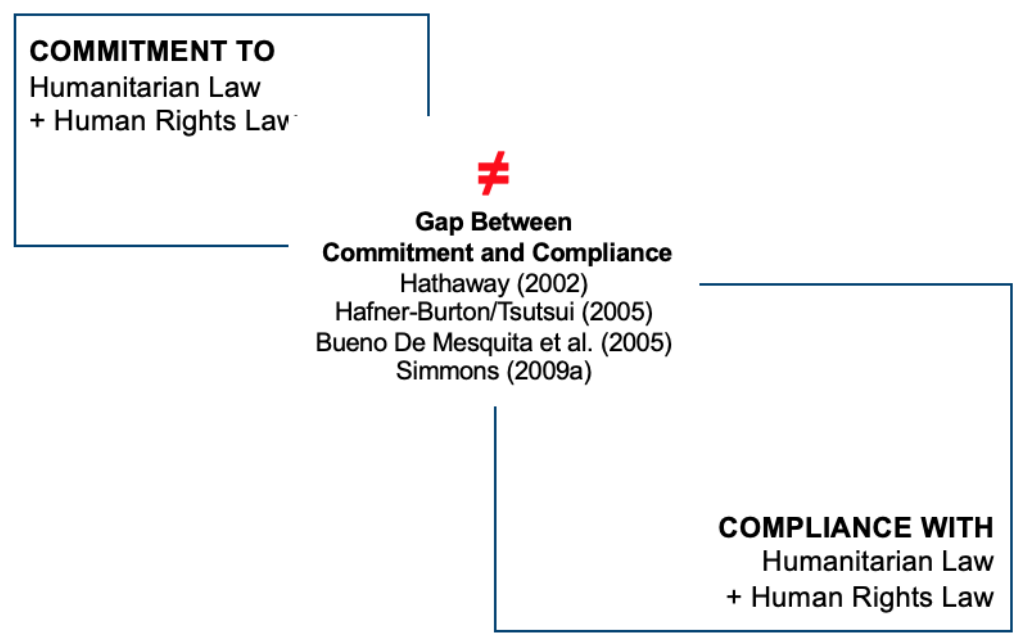

Figure 3: Gap between Commitment and Compliance

The empirical studies on the gap of the states' behavior on commitment and compliance (Hathaway, 2002, Simmons, 2009) show that human rights suffer enormously from spoiling and non-compliance. A higher level of ratification of human rights treaties without monitoring and enforcement mechanisms does not automatically lead to better human rights practices, but rather paradoxically sometimes even leads to an aggravation of human rights practices (Hafner-Burton/Tsutsui, 2005). Therefore, first and foremost human rights needs enforcement mechanisms to fill in the gap between commitment and compliance with humanitarian law and human rights. This is especially important when addressing severe human rights violations in the form of crimes against humanity (see Figure 4).

Guzman (2008a, 49ff.) is of the opinion that even if there are international courts or tribunals, they are not adequate to explain how international law shapes cooperation, since international courts are missing the backing of a state as domestic courts have it. Nevertheless, international courts and tribunals change the game and the three R's of compliance reputation, reciprocity and retaliation. Moreover, he mentions two important aspects that can make courts effective. Firstly, international courts can assist the states to find common understandings relating to international law and thus assist the states in legal dispute settlement. Secondly, international courts provide information on which states or individuals have violated international law. Both can help the states to find an appropriate response on norm violation. 


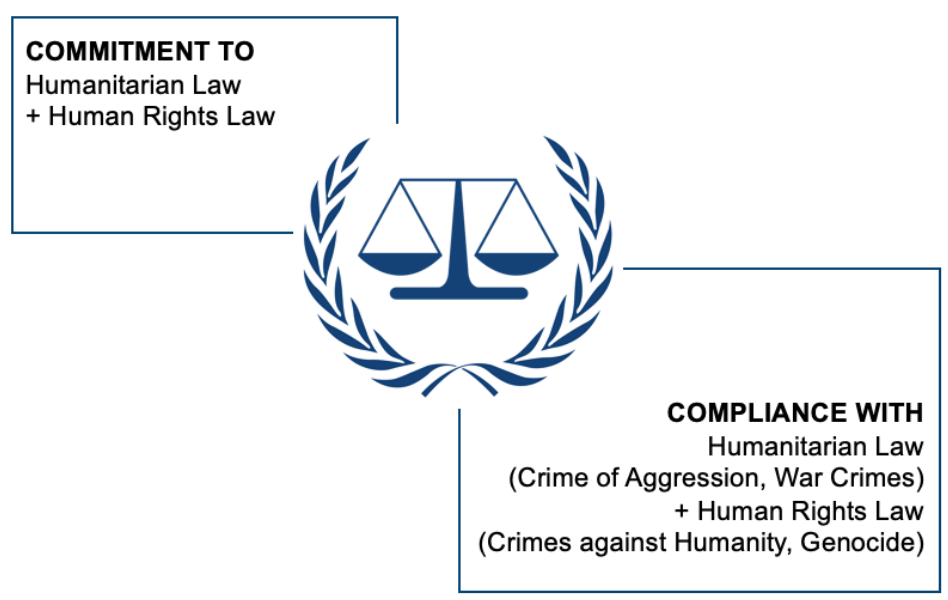

Figure 4: Establishing Courts Filling 'Partly' the Gap of Commitment and Compliance

\begin{abstract}
"A court is both an independent body that answers legal questions according to principles and rules of law, and the physical place where judicial proceedings occur. The common design of courtrooms and rituals associated with proceedings reflects the specific nature and importance of the administration of justice, with the normally high ceilings and formal décor reflecting and reinforcing the idea of the majesty of the law. Judges wearing robes sit above and apart from those participating in and observing the proceedings, while the disputing parties are placed in a position of physical equality before the panel. All rise when the judges enter and leave the courtroom." (Shelton, 2009, 2)
\end{abstract}

According to Shelton (2009) the miscellaneous international courts and tribunals can have different functions in international relations, such as dispute settlement, legal advice, monitoring compliance or the enforcement of law. In a similar manner Alter (2012c, 2014) distinguishes between the roles: enforcement, dispute settlement and constitutional/administrative review. Thus, we can observe a proliferation of international courts and tribunals (Romano, 1999, Kingsbury, 1999).

"When future international legal scholars look back at law and organizations at the end of the twentieth century, they probably will refer to the enormous expansion and transformation of the international judiciary as the single most important development of the post-Cold War age." (Romano 1999, 709)

According to Romano (1999) an international judicial body is characterized as follows:

"an international judicial body (...) must meet five criteria: First, it must be permanent

(...). Second, it must have been established by an international legal instrument (...). 
Third, in deciding the cases submitted to them, they must resort to international law. Fourth, they must decide those cases on the basis of rules and procedures, which preexist the case and usually cannot be modified by the parties. Finally the outcome of the process must be legally binding." (Romano, 1999, 713f.)

In this regard there are numerous permanent international and regional courts and furthermore several temporarily, international criminal tribunals (see in Table 2 24 On the international level, there are the International Court of Justice (ICJ), the International Tribunal for the Law of the Sea (ITLOS) and the International Criminal Court ([CC). On the regional level there are several 'courts of justice' monitoring the common law of the regional organizations, such as EU] Common Market for Eastern and Southern Africa (COMESA), Economic Community of West African States (ECOWAS), East African Community (EAC), Andean Community (AC), Caribbean Community (CARICOM. Moreover, there are three regional courts monitoring human rights, the ECHR the Inter-American Court of Human Rights (IACtHR) and the African Court of Human and Peoples' Rights (AfCtHPR).

Finally, several temporary criminal courts and tribunals dealing with a violent past of armed conflicts or state repression investigating and prosecuting international crimes, such as the crime of genocide or crimes against humanity. Those can be distinguished between Ad-hoc tribunals, hybrid tribunals and the ICC (Ambos, 2011, 131ff.). Adhoc Tribunals are constructed as subsidiary body of the UN-Security Council: the ICTY and ICTR. International tribunals based on a mixed hybrid statutory source bring together national elements of a crime and those of International Law. These include the Kosovo War Crimes Tribunal (KWCT) respectively the Kosovo Specialist Chambers (KSC), the Special Court for Sierra Leone (SCSL), the Special Panels for serious Crimes in Timor-Leste (SPSC), the Extraordinary Chambers in the Courts of Cambodia (ECCC), the Special Tribunal for Lebanon (STD) and the Iraqi High Tribunal (IIHT). Both the Ad-hoc Tribunals and the hybrid tribunals are established for a limited time period.

\footnotetext{
${ }^{24}$ For an overview of international courts and tribunals see e.g. the International Justice Resource Center: http://www.ijrcenter.org/courts-monitoring-bodies/(10-12-2018) or the Project on International Courts and Tribunals: http://www.pict-pcti.org(10-12-2018). There are moreover several dispute settlement mechanisms such as the Dispute Settlement Body (DSB) of the WTO They differ from the international courts as the states themselves have the decision making power as to whether to bring cases to the DSB or prematurely end the process and switch to diplomatic actions. The criterion of Romano (1999) that states cannot modify cases is not provided to dispute settlement bodies.
} 


\begin{tabular}{|c|c|c|}
\hline Court/Tribunal & Organization/States & Time Frame \\
\hline \multicolumn{3}{|l|}{ International Courts } \\
\hline International Court of Justice & United Nations Organization & permanent (1945) \\
\hline International Tribunal for the Law of the Sea & stand-alone & permanent (1982) \\
\hline International Criminal Court & stand-alone & permanent (1998) \\
\hline \multicolumn{3}{|l|}{ Regional Courts of Justice (Selection) } \\
\hline European Court of Justice & European Union & permanent (1952) \\
\hline COMESA Court of Justice & Common Market for Eastern and Southern Africa & permanent (1993) \\
\hline ECOWAS Court of Justice & Economic Community of West African States & permanent (1993) \\
\hline EAC Court of Justice & East African Community & permanent (1999) \\
\hline AC Court of Justice & Andean Community & permanent (1979) \\
\hline CARICOM Court of Justice & Caribbean Community & permanent (2001) \\
\hline \multicolumn{3}{|l|}{ Regional Human Rights Courts } \\
\hline European Court of Human Rights & Council of Europe & permanent (1959) \\
\hline Inter-American Court of Human Rights & Organization of American States & permanent (1979) \\
\hline African Court of Human and People's Rights & African Union & permanent (1998) \\
\hline \multicolumn{3}{|l|}{ International Criminal Tribunals } \\
\hline International Military Tribunal & Allies \&Germany & temporary (1945-1949) \\
\hline International Military Tribunal for the Far East & Allies \& Tokyo & temporary (1946-1948) \\
\hline International Criminal Tribunal for the Former Yugoslavia & UN Ad-hoc tribunal & temporary (1993-today) \\
\hline International Criminal Tribunal for Rwanda & UN Ad-hoc tribunal & temporary (1994-today) \\
\hline Kosovo War Crimes Tribunal & hybrid tribunal UN \& Kosovo/Serbia & temporary (2000-today) \\
\hline Special Court for Sierra Leone & hybrid tribunal UN \& Sierra Leone & temporary (2002-today) \\
\hline Special Panels for Serious Crimes in East Timor & hybrid tribunal UN \& Timor-Leste & temporary (2002-today) \\
\hline Extraordinary Chambers in the Courts of Cambodia & hybrid tribunal UN \& Cambodia & temporary (2003-today) \\
\hline Special Tribunal for Lebanon & hybrid tribunal UN \& Lebanon & temporary (2009-today) \\
\hline
\end{tabular}

Table 2: International and Regional Courts and Tribunals 
The landscape of international courts and tribunals can be described as 'judicial globalization' (Slaughter, 2000a):

"Judicial globalization (...) describes a (...) diverse and messy process of judicial interaction across, above and below boarders, exchanging ideas and cooperating in cases involving national as much as international law." (Slaughter, 2000a. 1104)

The judicial globalization is observable in the developing relations of national and international courts and their judicial decisions in the emerging global community of courts. Judges meet each other to exchange knowledge and experiences and give advice. National and International courts often dialogue and cooperate, rather than standing in a hierarchical relation. They cite the interpretations and rulings of one another although they have no formal obligation to do so. In the case of the European Court of Human Rights that is cited frequently by other judicial human rights institutions like the UN Human Rights Committee or the Inter-American-Court of Human Rights and a 'judicial comity' has emerged. Foreign courts and their decision are respected and not just adapted as an institution of a foreign government ${ }^{25}$ Consequently, there is an increasing cross-fertilization and cooperation between national and international courts (Slaughter, 2000a).

If we talk about judicialization we not only refer to the expansion of international courts and tribunals on the international level, but also to the increasing importance of courts in domestic politics like the supremacy of constitutional courts (Vallinder, 1995 Shapiro/Stone Sweet, 2002 Hirschl, 2008). Hirschl (2008, 121ff.) observes three different processes that are identified as judicialization: first, the spread of legal rhetoric into the political sphere, secondly the expansion of courts determining political outcomes, and thirdly, courts dealing with mega-politics.

\footnotetext{
"Over the last two decades, the judicialization of politics has extended well beyond the now 'standard' judicialization of policy-making, to encompass questions of pure politics - electoral processes and outcomes, restorative justice, regime legitimacy, executives prerogatives, collective identity, and nation-building." (Hirschl, 2008, 138)
}

By creating and supporting international courts and tribunals, governments have to give up authority and autonomy that they usually protect resolutely and instead delegate power to third parties that get the final say about "issues that go to the heart of international political debate" (Katzenstein, 2014, 151) such as war crimes or crimes against humanity in the case of the ICC. One can consider it as a real conundrum that

${ }^{25}$ A detailed analysis of the influence of the ECHR on the development of the international law one can be found in Merrills (1993). 
states bind themselves to ICC given the fact that the court leads to a serious intrusion into state sovereignty by dispensing justice to states' nationals (Simmons/Danner. 2010). As mentioned at the beginning, binding themselves to an international court, especially to an international criminal court results in a serious intrusion into the sovereignty of a state. The central question is: why do states delegate authority to international courts and tribunals?

\subsubsection{Theories on States' Delegation to International Courts}

To better understand why states commit to the Rome Statute we gather the most enlightening answers in insight through the research on states motives for delegating authority to international courts. This research is helpful in grasping the particularities of becoming a state party to the ICC.

For a long time the central question of neoliberal institutionalism dealt with how and why states cooperate in the absence of supranational government. The establishment of international and regional organizations, and sometimes even the creation of courts raises the question as to why states delegate authority to international courts although they significantly limit the states' sovereignty. The response we get is that international courts and dispute settlement mechanism solve cooperation problems of international relations.

The conventional assumption of cooperation theory is that a longer shadow of the future makes cooperation more likely. Nevertheless, Fearon (1998) argues that the long shadow of the future can lead to the fact that states bargain harder because they are aware that this shadow may in the future apply to them as well, along with its consequences. Every fundamental solution regarding cooperation problems begins with resolving a practical one. This requires the states to bargain over the content of treaties. That means that states must decide what the contents of agreements are before they can decide on the monitoring or enforcing of international agreements.

A similar argument makes Koremenos (2007) when examining the question as to why states create or delegate dispute resolution authority. She demonstrates that about $50 \%$ of all agreements in the issue areas of economics, environment, human rights and security have dispute resolution mechanisms. She distinguishes 'cooperation problems' between those of interests and those of constraints. Interests can be either enforcement or distribution of preferences. Constraints are either uncertainty about preferences and behavior of the others or uncertainty about the consequences of cooperation in the general relation to the state of the world. She argues that states tend to decide for the 
creation or delegation of dispute resolution authority if they want to address complex cooperation problems, such as enforcement problems, uncertainty about the behavior of the others, uncertainty about the state of the world or commitment problems.

Alter et al. (2012) are of the opinion that international courts can protect states e.g. through the protection against private actors. However, on the other hand, they also are of the opinion that international courts can also undermine the states' ability to interpret the requirements of an international court. This results in the latter becoming rival actors in international relations. As such the delegation of authority to international courts depends on the states' intention to delegate (Alter, 2004). In making this argument she relies on Majone (2001) who introduced the argument relating to the delegation of authority to international organizations in general. He argues that the logic of delegation depends on its rationality and distinguishes between delegating either "to reduce decision making costs (...) or to enhance the credibility of policy commitments" (Majone, 2001, 103).

"[W]here the purpose of delegation is to reduce decision-making costs, the key problem (...) is bureaucratic drift, that is the ability of the agent to enact outcomes different from the policies preferred by those who originally delegated powers. (...) when credibility is the main reason for delegating powers (...) the best strategy (...) is often to choose a delegate whose policy preferences differ systematically from the preferences of the delegating principal. (...) In the first type of delegation the preferences of the principal and the agent should be aligned as much as possible, and the delegation structure so as to minimize bureaucratic drift and slippage. (...) Hence the second type of delegation implies that the delegate should be independent, although the level of independence may vary with the seriousness of the credibility problem." (Majone, 2001 103f.)

Alter (2004) takes up this argument and transfers it to international courts. She distinguishes states as principals on one side and courts as either agents or trustees on the other side. She argues that in the case of delegation of authority to international courts for the purpose of reduce transaction costs a principal takes a trustworthy 'agent' with similar values and norms into consideration hoping that the agent's interpretation of its mandate is similar to that of the principal. To ensure this, the principal will keep the agent under strict control. In the case of delegating authority in order to enhance the credibility of the state a 'trustee' is selected for his reputation with the expectation that the trustee follows the professional norms for which this reputation was earned. Under the above-mentioned circumstances, it becomes unnecessary to try to control the trustee (Alter, 2004, 9ff.).

She makes a similar argument later that there is a systematic difference in delegation as states make a 'self-binding' or 'other-binding' delegation to international courts 
dependent on their expected functions, such as judicial roles dispute adjudication, enforcement (monitoring police and prosecutors), administrative review or constitutional review. 'Self-binding' creates high sovereignty costs because the defendants are probably state actors. 'Other-binding' creates lower sovereignty costs because the defendants are mainly private actors. Thus, criminal enforcement, administrative review and constitutional review only work when the court's jurisdiction is compulsory (Alter, 2008). She concludes that the principals' control of courts are much weaker at the international level than it is at the national level, where governments have more tools limiting courts and judges (Alter, 2006).

\footnotetext{
"The promise of delegation to ICs [i.e. international courts], or perhaps the nightmare of some, is that ICs will create a legal and political space where regular politics and the power disparities in the world do not shape outcomes. If delegation (...) succeeds in creating this space, (...) interpretations of international rules will be more authoritative than states auto-interpreting the rules to suit their interests, bringing with it a loss in state latitude and autonomy." (Alter 2006 337f.)
}

Thereby, she attributes to international courts a high independence from power political influences, since it is very hard for states as political actors to shape the outcomes in the courts. There is a huge debate in the research literature of IR and IL that deals with the question as to how independent international courts are and should be from power political ambitions of states. Important scholars involved are Helfer/Slaughter (1997, 2005) on one side and Posner/Yoo (2005a b) on the other side. The debate can be considered as vital for examining the determinants of states' commitment to international courts and tribunals, such as the ICC. It can be argued that states are afraid of delegating authority to independent courts that are so independent that they are out of their control. Conversely, they are afraid of delegating authority to international courts that are not independent and thus under certain circumstances fall under the control of opposing states.

Helfer/Slaughter (1997) developed a 'checklist' for an effective supranational adjudication that includes the following factors: a) factors within the control of states, such as functional capacity or independent fact-finding procedures, b) factors within the control of the courts, such as autonomy from political interests or judicial crossfertilization and c) factors beyond the control of states or judges, such as the nature of norm violations or a certain cultural and political homogeneity of the states parties. They argue that the success of the European Court of Justice (ECJ) and ECHR is due to these courts' autonomy and independence from power political interests. The checklist itself reflects these values. 
Posner/Yoo (2005a) are strongly opposed to this view. They argue that international courts and tribunals are problem-solving devices that become ineffective if they ignore the interests of the states parties ${ }^{26}$

"[I]ndependent tribunals pose a danger to international cooperation because they can render decisions that conflict with the interest of the state parties. Indeed, states will be reluctant to use international tribunals unless they have control over the judges. On our view, independence prevents international tribunals from being effective." (Posner/Yoo 2005a 7)

In response to this, Helfer/Slaughter (2005) developed the concept of 'constrained independence', arguing that states create independent international courts and tribunals, but afterwards constrain the independence of the courts:

"[S] tates establish independent international tribunals to enhance the credibility of their commitments in specific multilateral settings and then use more fine-grained structural, political, and discursive mechanisms to limit the potential for judicial overreaching." (Helfer/Slaughter, 2005 44)

They criticize Posner and Yoo creating a straw man, as it is the fundamental underpinning of courts that they maintain their judicial independence. In reply to this Posner/Yoo (2005b)warn of assuming international judges would be independent automatically. In their view, states are most likely to create international courts and tribunals for agreements that require an extensive modification of the national law of the states parties that deal with common problems and public goods or that create benefits or rights for private actors (Helfer/Slaughter, 2005, 39f.) ${ }^{27}$

As Helfer/Slaughter (2005) pose the question as to whether international courts and tribunals are dependent or independent; the courts and tribunals are in the center of their analysis. Accordingly, they analyze different cooperation problems and their influences on the creation of the institutional design of an international court or tribunal. In their view courts are constraint independent. They make no claims about variation in states delegation behavior or their influences on the process of constraint. Nevertheless, they see a general motive for delegating authority or rather creating international courts and tribunals in both the reduction of uncertainty about the behavior of the other states and the enhancement of credibility of commitments, since international

26 They also express this view in a study of the $[\mathrm{ICJ}$ arguing that the decisions of the court are influenced by the power political interests of the sending states of the judges (Posner 2004).

${ }^{27}$ In the case of the ICC we could consider all three factors to have been fulfilled. States have to implement norms on cooperation and complementarity. The violation of humanitarian law and human rights is a widespread problem and the Rome Statute affects individuals. 
courts reduce uncertainty through an empowered monitoring and by correctly labeling non-compliance. The costs of non-compliance, given this monitoring function, are twofold: firstly, the probability of sanctions as a penalty for non-compliance increases, not only through the work of the tribunal or court itself but also by a multilateral political process or even unilateral politics. Secondly, because of the correct identification of non-compliance, the probability of loss of reputation increases (Helfer/Slaughter. 2005 , 35f.).

Furthermore, committing to international courts and tribunals enhances the credibility of states. Here they take up the argument already discussed in the subsection of motives for states committing to international law Commitment to International Law (chapter 2.1). The basic idea of enhancing credibility is the same, but the argument why it functions is even stronger. They refer to the argument Alter (2004) made saying that an international court as independent institution acts rather as trustee than as agent because it is oriented towards professional norms and it is hard to be controlled by the states as principals (Alter, 2008, 38ff.). Helfer/Slaughter (2005, 42ff.) assume that states will choose dependent dispute settlement mechanisms if the cooperation problem that should be solved is bilateral. Delegation to an independent tribunal is not necessary in those cases. Showing the will to solve the problem is already a credible indication when the mode of bilateral solution is chosen. Dependent dispute settlement can be more effective when relying on diplomatic non-legal mechanisms. However, if the cooperation problem to be solved is multilateral, states create independent courts and tribunals because they act as trustees according to Alter (2004) and enhance the credibility of states.

Delegating authority to an international court as Helfer/Slaughter (2005) examine it, refers to the question of which kind of court they choose and is less targeted at the question why a state as a single actor decides to delegate authority. On the contrary, Posner/Yoo (2005a) argue that the motive for delegation is the appropriate solution for certain problems and simultaneously states are able to maintain and maximize their own interests. GGuzman (2008b, 208ff.) is of the opinion that although independence reduces compliance as the empirical reality show, this is not due to a higher effectiveness, but with changed incentive structures and lower costs for states to comply. If the aim is making commitments to international law more credible then international tribunals should be independent.

Moreover, there are several explanatory approaches making statements on the states' delegation of authority to the ICC. Sikkink (2011, 119ff.) considers the creation of the ICC as pivotal example of the spread of human rights prosecutions as part of 
the 'justice cascade' obtained through the engagement of a transnational network of lawyers from Netherlands, Sweden, Norway and Canada influenced by an epistemic community of criminal law lawyers and several human rights NGOs. In the change in the texts between 1994 and 1998 she sees the persuasive discursive power of the like-minded states and NGOs.

With a similar argument Deitelhoff (2009) explains the creation of the ICC and the costly delegation of states' authority with a normative shift in the states' interests. She is of the view that it is not possible to reduce law on cost-benefit calculations. She describes institutional change in the view of social constructivism as a result of persuasion and discourse within the negotiations of the Rome Statute. Those would have reached two central turning points. One pivotal point would have been in 1996 as there was no longer any remaining objection to the creation of the ICC:

" The first can be located in the move from the ad hoc committee in 1995 to the PrepCom in 1996. In contrast to the ad-hoc committee, where especially major powers argued against an ICC, no state publicly objected to the ICC as such in the PrepCom, though the type of court envisaged maintained controversial, partly due to differing legal systems and cultural contexts. At its heart lay a conflict over the normative basis of the court, that is, over a potential obligation to pursue international prosecution including the question of how to instigate proceedings (trigger mechanisms), the role of the Security Council, and the type of jurisdiction." (Deitelhoff, 2009, 49)

The second shift she sees shortly before the Rome Conference:

\footnotetext{
"A second turning point lies between 1997 and 1998, after the PrepCom sessions and before the Rome conference. During this period, positions changed dramatically until the end of 1996, a majority of states pushed for a very conservative ICC model. Led by the P5, this group called for a court under the control of the Security Council. This meant that the council would have to approve each case upon investigation (veto of P5). They also rejected the initial proposals for an ex-officio prosecutor, and they disliked automatic jurisdiction but favored several opt-in/opt-out mechanisms or a state consent regime to establish the court's jurisdiction. In essence, they wanted a kind of permanent ad hoc tribunal. The P5 defended this conservative position by arguing that their particular responsibility for peace and security should justify a special protection from the ICC." (Deitelhoff, 2009, 49f.)
}

According to Deitelhoff (2009) those shifts of positions cannot be explained with rational arguments, since the material power structure remained the same while the discourse and structure of the negotiations had changed. The Rome Statute is not a reflection of rational consensus, but rather of designed compromises affected by persuasion and discourse. International law ensures that the rational for decisions doesn't 
have to be made over and over again, but there is a consistent logic of justifications that arise from negotiated compromises.

\footnotetext{
International law "reflects a framework of legitimacy, defining the range and limits of political debate, which is not easily circumvented. Law generates a particular form of legitimacy that some attribute to the form characteristic of law, though the process through which law is generated seems to be of particular importance. Lawmaking brings into play the legal system as a whole with its greed-upon principles, and procedures of due process. Its specific legal discourse devalues arguments based on power and interests and requires normative justification, based on legal precedent and analogy." (Deitelhoff 2002 , 34f.)
}

Katzenstein (2014) likewise raises the question why states create an international criminal court, such as the ICC, although they have to make a sacrifice of their sovereignty. She argues in the tradition of historical analysis that likelihood of creating an international criminal court depends on two factors. For one thing the international system has to be shaken by crisis before states become willing to cooperate. For another thing states are motivated by the crisis to turn to international legal networks searching for solutions. In the case of the ICC, she shows that World War I and II and the engagement of international lawyers had made decisive contributions to the creation of the core crimes overseen by the court. Diametrically opposed, there is the theoretical argument of Goldsmith (2003). He argues in a realistic manner that an effective punishment of genocide, war crimes or crimes against humanity are unrealistic. One of the most important reasons she sees is the reluctance of the USA to participate in its current formulation. As the ICC depends on the USA's economic, military and political support their participation would be necessary. Moreover, the threat of jurisdictional overlap would hinder the USA engagement in humanitarian intervention resulting in the ICC being set up for failure from the outset.

\footnotetext{
"[C]ommitment to equal justice and the 'rule of law' might have produced perverse effects in several ways. The ICC founders might have assumed that abstract normative principles, once embodied in international law, will influence nations in favorable directions independent of their power and economic political interests." Goldsmith (2003 99)
}

In his eyes moral commitments are difficult or even impossible to match with the political reality of international relations. One solution for the ICC would have been trying human rights abusers in new democracies, while immunizing human rights enforcers, such as the USA. Although the positive and negative considerations repeat many of the old debates of idealism versus realism, we can find some more differentiated approaches in the strand of liberal theory of international relations. Ginsburg 
(2009) developed the theoretical argument of a 'clash of commitment' at the ICC, a commitment to deter mass atrocities is contrary to a commitment not to prosecute atrocities or to grant amnesty in the context of transitional justice. He emphasizes that the ratification of the Rome Statute, while considered as a credible commitment of tying the own hands, must be questioned since becoming a party state to the ICC makes it more likely to prosecute rebels than to prosecute governments.

\subsubsection{Empirical Studies on Delegation to International Courts}

In case of the theoretical approaches on commitment to international law, there are comparatively few empirical studies testing the arguments of states' motivations on delegating authority to international courts and tribunals. Those existing studies pay attention either to the level of the courts themselves and the question why they were established or to the level of states and the question why they delegate authority to international courts and tribunals despite this meaning an intrusion into their state sovereignty.

Koremenos (2007) for instance, who argues in the tradition of neoliberal institutionalism, follows the theoretical approach on states establishing international dispute settlement mechanisms dependent on the complexity of the cooperation problems that ought to be solved. Testing her argument empirically she chooses a random sample of international agreements in the issue area of security, human rights, environment and economics and codes them with 375 questions relating to the cooperation problem to be solved. She develops key dimensions to be able to measure variation in the form of dispute resolution, such as mediation, arbitration or adjudication. Finally, she tests different hypotheses on the influence of complexity of cooperation problem with the help of cross-tabulations and probit regression analyses and comes to the result that states use formal dispute resolutions often when the problem could be eased by such provisions. In that respect the ICC as an international court was created in order to that it must solve the complex cooperation problem enforcing international criminal law.

Katzenstein (2014) gives empirical evidence to support her argument of historical institutionalism that international courts are created dependent on both the willingness of cooperation of the states in times of crises and the activation of international legal networks. She does this by making a historical analysis for the time frame of the second Hague Conference in 1907 up to the establishment of the ICC with the Rome Conference in 1998. For the different stages in the development of the ICC, she exam- 
ines her assumptions on the influence of states, especially hegemonic states, and the engagement of international legal networks.

Deitelhoff (2009) comes to her assumptions on the establishment of the ICC with the help of a content analysis of all press releases and summary minutes of the negotiations on the Rome Statute between 1994-1998. Moreover, she carried out several interviews. Thus, she gives empirical evidence for her argument based on the assumptions of social constructivism that the creation of the ICC cannot be explained through states' interests, but through a change of positions according to a shift of discourse and persuasion.

Some empirical studies on delegation authority to the ICC can be found mainly in studies of neoliberal institutionalism. Simmons/Danner (2010) developed the theory of 'credible commitments' to the ICC. They argue that it is hard for states to convince other states that they are going to behave in a certain way that raises high costs in the short term, although it produces great benefits in the long term. The ICC is one possible solution for the problem of lack of credibility, since it raises the costs of reneging and increases both the international and domestic audiences' attention and thus makes the states' commitments more credible.

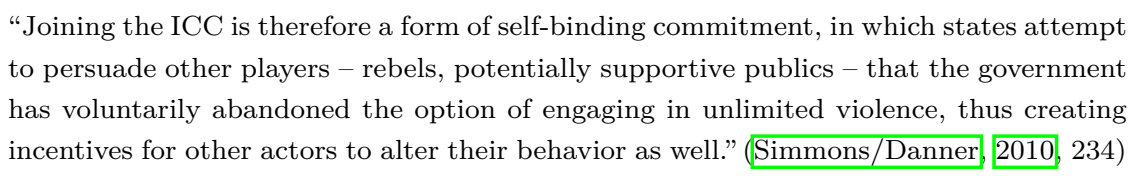

Central explanatory factors for commitment to the ICC are in their view: the state being a democracy or a non-democracy, the rule of law of a state and the existence of armed conflicts in recent years. Accordingly, they develop three hypotheses on the likelihood of states' ratifying the ICC. First, non-democracies with a low rule of law and recent civil wars are likely to ratify the ICC. Second, democracies with a high rule of law and recent civil wars are not likely to ratify the ICC. Third, democracies with a high rule of law and no recent civil wars are not likely to ratify the ICC. In an event history analysis for 1998-2007 they test their hypotheses examining time-varying and constant factors. They come to the results that indeed non-democracies with recent civil wars are much more likely than e.g. non-democracies without recent civil wars. Moreover, they show that democracies without recent civil wars tend towards a ratification of the Rome Statute because they want others to be held accountable for committing atrocities.

Chapman/Chaudoin (2013) question the results of Simmons/Danner (2009) and criticize the operationalization of the variables, the methodical approach and the robust- 
ness of results. Likewise, they focus on the recent history of the states and their legal and political institutions. They show that the states that ratified the Rome Statute differ considerably from those states that did not ratify by relating to their experience in armed conflicts and the strength of domestic legal and political institutions. They contradict Simmons/Danner (2009) and their thesis that non-democracies with recent civil wars and a low rule of law would be more likely to ratify the Rome Statute. Instead they hold the view that democracies without recent civil wars are most likely to ratify the Rome Statute while non-democracies with a weak rule of law and recent civil wars are least likely to ratify the Rome Statute. That they come to different results then Simmons/Danner (2009) in their opinion is reasoned in a different operationalization of the key variables and the fact that it is very hard to interpret both interactive effects and hazard ratios.

Dutton (2011) developed a methodical approach examining the determinants of state commitments to the ICC as well. She argues that states with good human rights practices and strong domestic enforcement mechanisms are most likely to ratify the Rome Statute, since the states are most concerned about high costs of non-compliance and a possible loss of sovereignty. Thereby, she refers to Simmons/Danner (2009) and argues that it is not convincing that non-democracies with a weak rule of law are overwhelmingly willing to submit to the ICC. Referring to Hathaway (2002) she argues that states calculate the costs of commitments to international treaties and would be less likely to commit to an agreement if they anticipate that they will not be able to comply. Accordingly, she develops the theoretical argument of 'credible threats' saying that state with better human rights practices and stronger domestic enforcement mechanisms are more likely to ratify the Rome Statute. Using a history event analysis (1998-2008) and proportional hazard regression she tests her theoretical expectations and comes to the conclusion that particularly good human rights practices are able to explain the likelihood of ratification of the Rome Statute.

An entirely different approach is taken by Goodliffe et al. (2012). They ask why states bind themselves to the ICC. They explain that the decision to ratify the Rome Statute was based on interdependent networks with other states, such as security alliances, trade relations or common memberships in an International Organization (IO). They argue that the exchange partners of a state may be able to control certain goods and therefore a state takes care for good relations to its partners. Therefore, they develop the hypothesis that the higher the dependency the more likely the probability of succeeding in ratifications or non-ratifications. Operationalizing their assumption, they measure formal alliances, financial exchange and membership in multiple IOs. 
In an event history analysis for the time between 1998-2004, they test their argument explaining levels of commitment measured by signature and ratification. They develop an index of dependence and show that there is a relationship between their index position and their level of commitment to the ICC. In their view, this shows a kind of diffusion of commitment to the ICC via the mechanism of coercion.

A further empirical study that deals with issues regarding commitment to the ICC was delivered by Kelley (2007). She is not interested in the explanatory factors for the ratification of the Rome Statute, but in the question as to why some states concluded a Bilateral Immunity Agreement (BIA) with the USA. These agreements also commonly referred to as Art. 98 Agreements shield citizens of the USA from surrender to the ICC ${ }^{28}$ This places in question the states commitments to the ICC. She argues that states refuse to sign a BIA if they believe in the ICC and want to support it. Accordingly, she develops two hypotheses. According to the first hypothesis, likeminded groups, states with good human rights practices, democracies and militarily weak states are more likely to ratify the Rome Statute and to refuse signing a BIA. According to the second hypothesis, states parties with a strong rule of law are less likely to ratify a BIA than non-states with a strong rule of law. Using a logistic regression analysis, she showed that democracies, members of a like-minded group and states with good human rights practices show a higher probability of ratification. Explaining the signing of BIAs the results do not remain robust and it becomes apparent that e.g. states with a low rule of law are more likely to sign an BIA if they are state party to the ICC. In the same manner states with a high rule of law do not necessarily ratify the Rome Statue. For Kelley (2007, 586) these results show that many states do not take their commitments very seriously.

\footnotetext{
28 The negotiation of the non-surrender agreements under the Bush administration can be considered as an expression of the US-American wish to hold 'human rights abusers' accountable while immunizing 'human rights enforcers' as expressed by Goldsmith (2003).
} 


\subsection{Research Gaps and Contributions to the Literature}

\subsubsection{Opening the Black Box of States Parties to the ICC}

When looking at the conceptualization of commitment to international law or international court it becomes visible that commitment is mainly understood as the mere act of ratification - or comparable alternative acts - becoming a state party to the respective law or courts. Looking at the determinants of such a commitment conceptualized as ratification we find empirical evidence for the fact that especially democracies tend to ratify human rights treaties (Simmons, 2009 Hathaway, 2002). There are reasonable grounds to question this narrow conception of commitment. For one thing, particularly in the legal area of human rights there is a common wisdom in literature of IR an IL that the ratification of human rights treaties does not inevitably lead to better human rights practices.

Even in autocracies there is often a worsening of human rights performance, since the pressure of transnational civil-society actors leads to a short-term rise of human rights violations (Hathaway, 2002, Hafner-Burton/Tsutsui, 2005). Positive effects of ratification levels on human rights performance can only be observed in democracies (Buneo De Mesquita et al., 2005). Thus, there is a huge gap between commitment to human rights and compliance with the respective norms. The gap is described as a form of 'costless expressions' (Hathaway, 2002), 'empty promises' (Hafner-Burton/Tsutsui, 2005 ) or 'window dressing' (Simmons, 2009). Additionally, and perhaps more decisive, those studies that conceptualized commitment further reaching than mere ratification came to the result that democracies in particular tend to make reservations and interpretative declarations (Neumayer, 2007) or show other qualitative differences in their commitment behavior (Simmons/Danner, 2009).

It should be put into perspective if it makes sense to measure commitment only in light of ratification of the founding treaties. In this manner we see only two homogeneous groups of states; those that have ratified and those that have not. In the case of international courts and tribunals ratification of the founding treaty can be considered even less a sufficient indicator for comprehensive commitment, since the self-binding to a court requires even more support of the states parties than just recognizing a single agreement. Of course, ratifying the founding treaty of an international court to become a state party is the most pivotal step. In most of the cases there is no regional or even international government. It is the states themselves that oversee the running the of court, be it with financial material or human resources. 
Being merely a state party does not demonstrate enough commitment. Empirical reality shows that there are many cases of non-compliance both with the core norms and with the procedural norms. The frequent problems of non- cooperation with the ICC mentioned in the introduction has shown this. The conception of commitment as mere ratification contributes to a worsening of human rights performance. The states are considered as 'committed' as soon as they have ratified the respective agreements, but do not have to show further indications of commitment. For scientific and political reasons there is a need to conceptualize commitments more comprehensively in order to open the black box of states parties to the ICC. Accordingly, the first research question is:

Research Question 1 - How strong is the commitment of states to the ICC Beyond the Ratification of the Rome Statute?

As a result of conceptualizing comprehensive commitments to the ICC variation is created within the group of states parties. This variation shows that there is a huge difference in the extent of commitment, ranging from a very high level over strongly constrained and customized commitments up to hardly or non-commitment. This empirical variation not only gives a valuable evaluation of states behavior to the ICC, but also makes visible the different kind of states parties to the ICC. This allows for the examination of the determinants for the extent of commitment beyond the mere ratification of the Rome Statute.

\subsubsection{Different Incentives in Delegating Authority to the ICC}

There are several approaches in the literature explaining states' delegating authority to international courts and tribunals. They, however, are fairly close to the narratives of the debates on explaining states' cooperating in international politics or states' decision to commit to international law. Interestingly, there is hardly any distinction in research explaining states' those states commitment to agreements where oversight of the courts is provided for and states' commitment to agreements in which there is no oversight of a court.

Moreover, there are only very few empirical studies testing explanatory factors for states' delegating authority to international courts and tribunals in general and the ICC in particular (Katzenstein, 2014 Deitelhoff, 2009 Koremenos, 2007) that has the consideration inherent that delegation to international institutions is a possibility of achieving interests at the level of international relations. 
In summary, it is remarkable that most of the theoretical arguments focus on which kind of dispute settlement mechanism should be or were created for which kind of cooperation problem. Alter (2004, 9ff.) argues that the extent of delegation depends on the cooperation problem solved. If states want to reduce transaction costs, they choose 'agents' with similar norms and values. If they want to make their commitment more credible then they choose 'trustees' with different norms and values. Helfer/Slaughter (2005, 39f.)are of the opinion that states create courts and tribunals for agreements that deal with common problems and public goods. Those create benefits or rights for private actors or require an extensive modification of the national law of the states parties. Similarly, Koremenos (2007) argues that states choose adjudication if the cooperation problem is particularly complex.

Although their theoretical approaches differ to some extent, they all ascribe the states having the same interests and preferences towards a certain international court or tribunals. It assumes that all states have the need to reduce transaction costs or enhance their credibility. This is very puzzling since the core issue of every court is to settle disputes on a legal basis. This results in the almost paradoxical state that those who must delegate authority - the states themselves - remain static in their incentives. There are no theoretical assumptions on variation in their interests and preferences. However, we can expect the solution of cooperation problems does not lead inevitably to benefits for all states. It might be due to the fact that increasing proliferation of international courts and tribunals is a phenomenon of the 21th century. For both legal and political scholars the search for an institutional design that encompasses an effective court able that is able to settle disputes is always present.

Arguments regarding the delegation to political institutions, such as those of Fearon (1997) or Majone (2001), are often transferred in order to explain delegation to courts. They do not mention differences in delegation to regimes with and without courts. We can expect differences in states commitment to agreements where oversight of the courts is provided for and states' commitment to agreements in which there is no oversight of a court.

Another research gap exists where the issue area of international law is ignored. Scholars of IL or ICL deal with the relationship of the norms on international law that shall receive criminal responsibility through the establishment of an international criminal court (Kreß, 2010, Paulus, 2010; Ambos, 2011). Scholars of IR often mention only aspects of human rights in relation to the ICC while aspects of humanitarian law are often left open. Astonishingly, there are a plethora of theoretical considerations on the proliferation of human rights and the respective states' commitment and compliance 
behavior. There are only a few considerations of states' behavior to humanitarian law in the view of IR. This might be explained by the fact that the area of human rights research emerged in the course of the political promotion of human rights and many studies make the normative claim supporting global proliferation and monitoring of human rights. There are hardly any studies in IR that associate the core crimes of the Rome Statute and the commitment to the ICC with the commitment to human rights law and humanitarian law. However, there are considerable differences in the possibilities of solving cooperation problems.

\footnotetext{
"From the political science side, if law - whether international, transnational or purely domestic - does push the behavior of states toward outcome other than those predicted by power and the pursuit of national interest, then political scientists must revise their models to take account of legal variables." (Slaughter, 1993 206)
}

According to the assumption that states do have different incentives to behave in a certain manner towards international courts the second research question is:

RESEARCH QUESTION 2 - What EXPLAINS THE EXTENT OF COMPREHENSIVE COMMITMENT TO THE ICC?

In order to find explanatory factors for the variation of states' commitment to the ICC, it is important to take the individual levels of commitment into regard. This shows that a comprehensive commitment depends on states' individual costs and benefits due to international norms that are to be enforced by the court. Those are dependent on the commitments to humanitarian law and human rights law that the states have already made. Thus, it is not only pivotal how democratic a state is, but the comprehensive commitment to the court depends on its possibilities to solve cooperation problems of international law. In particular democracies constrain and customize their commitment if they are unable to gain enough benefit from becoming a state party to the ICC. 


\section{Theory of States' Constraining and Customizing Commitments to the ICC}

In the following chapter it will be argued that states constrain and customize their commitments to the ICC due to their possibilities solving cooperation problems of international law. Despite strong incentives to become a state party to the ICC, there are also strong reasons to be cautious because the states' fear the ICC could be too weak and become politicized or even become too strong and thus, overreach its mandate. The states are caught in a delegation dilemma towards the ICC. No ratification would mean to waive support in improving freedom and security. However, ratification poses a high risk of experiencing comparative disadvantages when protecting freedom and security. Constraining and customizing the commitments to the ICC poses a way out of the dilemma.

According to the 'justice cascade' of Sikkink (2011) the universal norm of criminal accountability spread around the globe promoted through some of the core treaties of humanitarian law and human rights, such as Genocide Convention of 1948, Geneva Conventions of 1949 or Convention against Torture of 1987. This reached its peak with the establishment of the ICC. It will be argued, that although monitoring or even the enforcement of human rights is not the explicit task of the ICC, states behavior towards the court is connected with their actual extend of commitment to humanitarian law and human rights law since the core crimes in the Rome Statute are based on those of human rights law and humanitarian law. Becoming a state party to the ICC is thus a possibility of solving cooperation problems of international law such as reducing cost of monitoring and increasing credibility of commitments to human rights law and humanitarian law. Constraining and customizing commitments present the possibility to mitigate the potential risks and to maximize the benefits of becoming a state party to the Rome Statute.

In pursuit of these arguments, it will be illustrated the extent of which the core crimes of the ICC are based on the norms of humanitarian law and human rights law and why the ICC can be considered as their indirect guardian (3.1). Subsequently, the incentives for states of ratifying the Rome Statute and becoming a party to the ICC will be described (3.2), such as privileges of being a state party, receiving support from the ICC and the international community in dealing with a violent past and first and foremost, the possibility of solving cooperation problems of international relations. Afterwards, it will be pointed out how self-binding to the ICC can potentially lead to a certain reduction of room for political maneuver, which could mean a high risk for the 
states (3.3). Since the ICC is a court of complementarity, it misses clear institutional counterparts at the level of international institutions and is not able to protect the states. Thus, they have to retain a certain room for political maneuver, particularly, as the consequences for states of becoming a state party to the ICC are not well foreseeable: What if the ICC turns out to be too weak in confronting the power of the states, thereby becoming a gateway for politicization. Sometimes this situation might even be instrumentalized by those political opponents with whom peace was sought? What if the ICC turns out to be too strong, so that the principle of complementarity is eroded. This could result in the states being in danger of losing more autonomy and self-determination than expected?

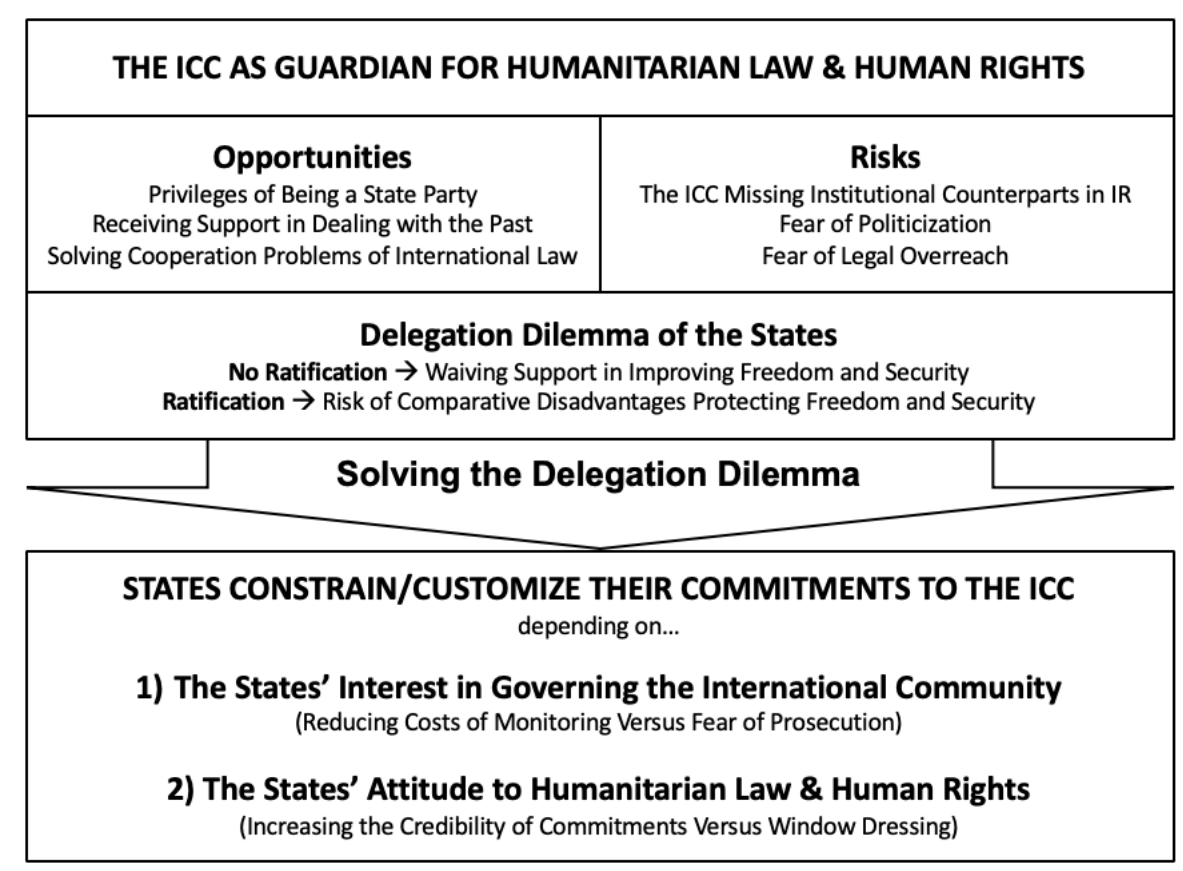

Figure 5: States Constraining and Customizing their Commitments to the ICC

It will be shown that states get caught in a DELEGATION DILEMMA towards the ICC: ratifying the Rome Statute and becoming a state party to the ICC would mean both a serious intrusion into their sovereignty and a high risk towards experiencing comparative disadvantages towards spoiling states. However, not to ratify would mean to waive the benefits of the ICC the states unequivocally need. In order to solve the 
DELEGATION DILEMMA towards the ICC, states constrain and customize their formal commitments to the ICC (3.4). Thereby, the extent depends on their interest in reducing costs of monitoring humanitarian law and human rights through establishing the ICC as well as the commitment to treaties of humanitarian law and human rights law the states have made previously (3.5).

\subsection{Guardian of Humanitarian Law and Human Rights Law}

To understand the behavior of the states and the reasons why they benefit from becoming a state party to the ICC, it is worthwhile to look at the norms that will be enforced and the reasons why the court was established. The ICC has several particular features. However, the arguably most important among them is that the ICC is the first permanent international court in charge of investigating and prosecuting humanitarian law and the most severe violations of human rights and therefore holding individuals accountable at the level of international criminal law. Since the ancient Greeks, war criminals were prosecuted to deal with the worst atrocities of armed conflict. The idea was recognized that even under circumstances of war, there are fundamental values and morals that must be respected. Those war tribunals were mainly national or local and were often ineffective, even if those that were responsible for the war crimes remained in power and prosecuted the political opponent (Schabas, 2011, 1f).

With the Hague Conventions $(\mathbb{H C})$ of 1899 and 1907, including their annex "Regulations concerning the Laws and Customs of War on Land", the first substantial codifications of law of war on the international level were established. These defined the term of combatants, determined permissible means and methods of war and prescribed the behavior towards e.g. ceasefire and prisoners of war. After World War II, the humanitarian law received its core with the Geneva Conventions (GC) 1949, protecting the wounded and sick in armed forces in the field (GCI), the wounded, sick and shipwrecked members of armed forces at sea (GC II), the treatment of prisoners of war (GC III) and the protection of civilian persons in times of war (GC IV).

The codification of the humanitarian law in the shape of the Hague and Geneva Conventions was based on the consideration that in times of armed conflict the possibility of alleviating the suffering of the civilians and prisoners depends on the behavior of the combatants treating them in a humanitarian way (Sandoz, 2001, 110). Meanwhile, at least 25 treaties on the regulation of international and non-international armed con- 
flicts have emerged, including the treaties on the ban of certain types of weapons ${ }^{29}$ However, the most path-breaking step towards international criminal law was the creation of the IMT in 1945 and the [MTFE in 1949 dealing with the atrocities of World War II. This was not only the birth of the modern international criminal courts, but they also established the crime against humanity and the groundwork for the crime against aggression.

Based on the ideas of Raphael Lemkin, a Polish-Jewish legal scholar, in 1946 the United Nations General Assembly (UN-GA) passed Resolution 96, declaring genocide an international crime, which is incommensurable with the aims and goals of the United Nations. In 1948, the "Convention on the Prevention and Punishment of the Crime of Genocide" was adopted.

In the same year, the UDHR was adopted and the concept of human rights was brought to an international public. Although there is no clear hallmark for a right being called a 'human right', there is a widespread consent that human rights shall prevent individuals against arbitrary behavior of states to their civilians. They also require the assistance of governments to protect dignity and freedom against the attack of third parties under the rule of law and the states' authority. Thus, human rights can be considered as a "complex set of norms calling not only for remedies against state interference, but also for proactive state action in favour of indigent members of society" (Tomuschat, 2014, 5).

In the following years, several international human rights agreements were adopted, such as the International Convenant on Civil and Political Rights (ICCPR) or the International Convenant on Economic, Social and Cultural Rights (ICESCR), but also several conventions on certain human rights such as the CAT of 1984 or the CRC of 1989. Up to now there are at least 18 human rights treaties 30 on the international level and numerous human rights treaties $\$ 1$ on the regional level, e.g. the "European Convention on Human Rights" (1950) or the "African Charter on Human and People's Rights" (1981). Therefore, we can distinguish between 'human rights' and 'human rights law', whereby the latter refers to legally binding treaties with the aim to promote the idea of human rights.

${ }^{29}$ For an overview of the treaties on humanitarian law and their ratification status, see https://ihl-databases.icrc.org/ihl (15-03-17).

30 For an overview of the international human rights treaties and their ratification status, see http://indicators.ohchr.org (15-03-17).

31 For an overview of the regional human rights treaties and bodies, see http://www.ijrcenter.org/regional/ (15-03-17). 
The rapid diffusion of human rights is most of all due to the growing activism of "Transnational Advocacy Network (TAN)' 32 in the 1970s and 1980s. This includes non-governmental organizations Non-Governmental Organization (NGO)s like Amnesty International (AI), social movements or research networks (Keck/Sikkink, 1998, 9). With regard to the rise of international human rights prosecutions, Sikkink (2011, 5) speaks of a "justice cascade" meaning "that there has been a shift in the legitimacy of the norm of individual criminal accountability for human rights violations and an increase in criminal prosecutions on behalf of that norm".

Important steps thereby were both the promotion of core treaties of humanitarian law and human rights - such as the Genocide Conventions, the Geneva Conventions or the Convention against Torture - and the establishment of international, domestic and foreign criminal tribunals. Looking at the ratification status of human rights agreements around the globe we can see that some of them have imposing rates of ratification, such as the CRC of 1989 ratified by 196 states or the CEDAW of 1979 ratified by 189 states $\$ 3$ Especially the additional protocols have rather bad rates of ratification. The rates of compliance are bad too notwithstanding this good rate of ratification (Hathaway, 2002, Hafner-Burton/Tsutsui, 2005). This is in large part due to weak monitoring and a lack of enforcement mechanisms to ensure compliance with international law.

Since the end of Cold War, there have been growing numbers of civil wars and wars of independence in connection with the 'third wave' of democratization (Huntington, 1991). This began in Western Europe with the Carnation Revolution in Portugal 1974, continuing in South America and South East Asia and peaked with the collapse of Yugoslavia and the Soviet Union. The establishment of several states and the transition from authoritarian military dictatorships to marked-based democracies created the need for a conscious repossessing of the past to promote peace and reconciliation and, ultimately, democracy (Merkel, 2004). In this political climate, the phenomenon of T.J emerged, based upon the assumption that the transition from conflict to peace and thereby from the perception of threat to the perception of security needs the reappraisal of past atrocities.

The instruments of T.J can adhere to either an offender orientated retribution or victim orientated restoration rationale. There are several domestic and bilateral political instruments, such as places of remembering, apologies, reparations, lustrations or in-

\footnotetext{
32 Keck/Sikkink (1998, 2) define "transnational advocacy networks" as "relevant actors working internationally on an issue, who are bound together by shared values, a common discourse, and dense exchanges of information and services".

33 State as of 20-02-2017, see http://indicators.ohchr.org (13-03-2017).
} 
stitutional reforms ${ }^{34}$ Moreover, there are instruments that use legal tools to cope with the past on the domestic or international level, such as amnesty as an conscious act of collective oblivion (Cobban, 2007; Vinjamuri/Boesenecker, 2007), establishing a Truth and Reconciliation Commission (TRC) (Rowen, 2017, Hayner, 2010) and, first and foremost, the temporary creating of an International Criminal Tribunal (ICT) (Findlay/Henham, 2005, Geiß/Bulinckx, 2006 Cronin-Furman, 2013).

The ICT can be distinguished according to their legal basis into Ad-hoc and hybrid criminal tribunal 35 The Ad-hoc tribunals [CTX and [CTR were established 1993 respective 1994 as subsidiary bodies of the UNO whereas hybrid tribunals, such as the SCSL the ECCC or the KSC have a mixed national-international legal base and have both national and international prosecutors and judges at their disposal (Ambos, 2011).

Although all the international criminal courts and tribunals strengthen the awareness and importance of international criminal law and concurrently humanitarian law and human rights, they struggle with numerous difficulties. Those are e.g. the ambiguous application of law; lack of democratic legitimization; limited financial, personal and material resources; lack of witness protection programs and political forces trying to misuse the courts and tribunals for their own benefit. The ICC as treaty-based permanent international court, with its sophisticated institutional design, working complementary to and in cooperation with its states parties, applies the prior experiences and mistakes of the Ad-hoc and hybrid tribunals and has taken international criminal law to the next level $B 6$

The court speaks to an international audience and raises awareness for the norms of international criminal law and can be used by all states worldwide to cope with past atrocities. The ICC guards well-established, but up to then, toothless norms. In the

${ }^{34}$ Literature on the domestic and foreign political TJ-instruments: Places of remembering, e.g. memorials or museums (Booth 2001 Barsalou/Baxter 2007); apologies by the offenders (Barkan/Karn 2006 Swart 2008); reparations in terms of financial or symbolic compensation (DeGreiff 2006 Lipscomp 2010); institutional reforms e.g. in internal security or military and lustration politics like vetting or disarmament (Boed 1998 David 2003 Horne, 2012).

35 A further possibility of a non-permanent criminal prosecution is the establishment of a non-permanent national war crimes tribunal, such as the "Bangladesh International Crimes Tribunal".

${ }^{36}$ In addition to the ICC, there are both domestic and foreign criminal trials that exist as permanent possibilities in an evolving three-level-system of international criminal justice (Ambos, 2011, 93): Domestic criminal trials are based on the prime responsibility of the states due to the principles of territory and personality, whereas foreign criminal trial are based on the principal of universal jurisdiction. Examples for this are e.g. the sentence of Rwandan citizen Onesphore Rwabukombe at the higher regional court in Frankfurt in 2014 because of aiding and abetting the genocide of the Tutsis in Rwanda in 1994 or the indictments against so called 'foreign fighters'. 
view of Teitel (2003) this somehow leads to a normalization of transitional justice and the ICC became the symbol of this normalization; investigating and prosecuting war crimes, crimes against humanity and genocide as a routine matter in international relations.

\begin{abstract}
"What was historically viewed as a legal phenomenon associated with extraordinary post-conflict conditions now increasingly appears to be a reflection of ordinary times. War in a time of peace, political fragmentation, weak states, small wars, and steady conflict all characterize contemporary political conditions. These contemporary developments have spurred the attempted normalization of transitional justice, leading ultimately to ambivalent consequences. As a jurisprudence associated with political flux, transitional justice is related to a higher politicization of the law and to some degree of compromise in rule-of-law standards." (Teitel 2003, 89f.)
\end{abstract}

This explains why the ICC is accompanied by hopes and expectations and why Kofi Annan speaks of "a gift of hope to future generations, and a giant step forward in the march towards universal human rights and the rule of law' $\sqrt{37}$

Since the ICC is able to investigate and prosecute individuals even in states that are not party to the ICC, it can be considered as the most powerful one among T.J instruments, and perhaps even the most powerful among international courts in general. For those states that have already committed to humanitarian law and human rights, it is especially worthwhile to commit to the ICC.

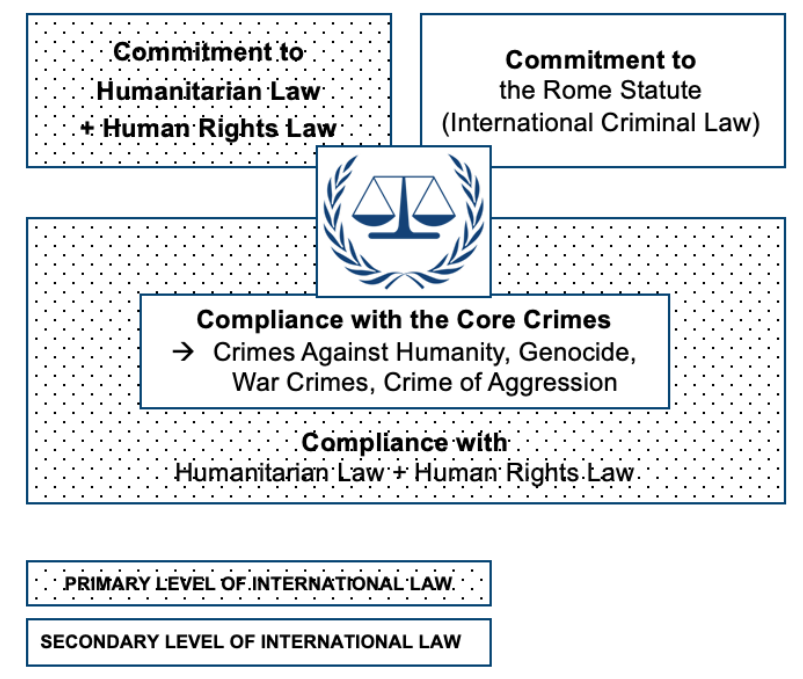

Figure 6: Relationship of First and Secondary Level of International Law

${ }_{37}$ UN Press Release L/2890: http://www .un.org/press/en/1998/19980720.12890.html (08-08-17). 
Although the ICC is not created to improve the enforcement of humanitarian law and human rights (on the primary level of international law) it can have this indirect effect through creating criminal responsibility for the four core crimes genocide, crimes against humanity, war crimes and the crime of aggression (on the secondary level of international law). Thus, there is strong reason to believe that the ICC makes a difference in international relations, increasing compliance and enhancing the credibility of commitments made to the norms of humanitarian law and human rights. Particularly for states that are not willing to improve their human rights practices, the ICC can present a serious opportunity to bring justice and to end impunity of atrocities.

When we analyze the incentives for individual states to behave in a certain way towards the ICC, we have to ask: Qui bono? What are the possible benefits of supporting the ICC? What are the possible costs and risks? Which states would benefit of committing to the ICC and which would have a disadvantage in doing so? In order to answers these questions, in the following subsection, the existing privileges of states being a state party according to the institutional design of the Rome Statute, will be presented. Moreover, the role of international criminal courts in dealing with past atrocities in the context of transitional justice will be explained. Finally, the subsection will drill down on the answers of how the ICC can solve existing cooperation problems in international relations and, as a consequence, why states want to become a state party. 


\subsection{Why States Want the ICC - Incentives to Ratify the Rome Statute}

\subsubsection{Privileges of Being a State Party to the ICC}

Looking at the preamble of the Rome Statute, it is apparent that the ICC is accompanied by the inherent hope of ending global impunity and of strengthening international peace and security. States parties agree that they are:

\footnotetext{
"[c]onscious that all peoples are united by common bonds, their cultures pieced together in a shared heritage, and concerned that this delicate mosaic may be shattered at any time, [m]indful that during this century millions of children, women and men have been victims of unimaginable atrocities that deeply shock the conscience of humanity, [r] ecognizing that such grave crimes threaten the peace, security and well-being of the world, (...) [d]etermined to put an end to impunity for the perpetrators of these crimes and thus to contribute to the prevention of such crimes".
}

The downside of this agreement is that there are certain costs of sovereignty that the states have to pay when becoming a party to the ICC. We can consider sovereignty costs as rather low when states make commitments that constrain their behavior. States tend to accept those commitment, if they expect to get better collective outcomes. On the contrary, sovereignty costs are rather high when the agreements affect the relationship between states and their territories or states and their citizens, as the hallmarks of Westphalian sovereignty (Abbott/Snidal, 2000, 437).

\footnotetext{
"Of course, ordinary restrictions on domestic policies can have such effects in contemporary welfare states, but these are heightened and generalized when, for example, an international human rights regime circumscribe a state's ability to regulate its citizens. Similarly, the United States has correctly been concerned that an International Criminal Court might claim jurisdiction over U.S. soldiers participating in international peacekeeping activities or other foreign endeavors." (Abbott/Snidal, 2000, 437)
}

Seen in this way, we can consider the sovereignty costs towards the ICC as very high for at least three main reasons. Firstly, the ICC is able to investigate and prosecute individual persons. One of many explanations why the USA declines to become a state party to the ICC is because the court would have jurisdiction over soldiers active in foreign assignments. Secondly, the ICC is able to trigger investigations without referral of states, either if the Prosecutor initiates investigations proprio motu, after preliminary examination has been conducted based on information received from states, NGO; or UN organs and has decided that there is a reasonable basis for investigations (art.15), or if there is a referral of a situation by the UN-Security Council (art. 13(b)) according 
to chapter VII of the UN-Charter. Thirdly, the ICC is able to investigate and prosecute individuals of states that are not party to the Rome Statute, if the crimes committed occurred in the territory (i.e. land, vessel or aircraft) of a state party (art.12, para. 2 (a)), in a state that has accepted the jurisdiction of the Court (art.12, para.3) or if the crime is referred to the ICC by the UNSC to the ICC Prosecutor pursuant to chapter VII of the UN charter (art.13(b)). This is one possible explanation why the USA discourages other states from becoming a party to the ICC.

We can regard the costs of sovereignty as rather low if we take into account that the consequences of investigation and prosecution foreseeable because the jurisdiction of the ICC has a restricted mandate. Firstly, the ICC only has jurisdiction over crimes that have been committed by natural persons (jurisdiction ratione personae, art. 25) implying that the ICC is not able to make judgments, which affect a state or a government, as is the case at the International Court of Justice or the European Court of Justice. At this point in time, the Democratic Republic of Congo (ICC-01/04) has the highest number of arrest warrants. There are currently seven warrants of arrest 38 During the work of [CTY and [CTR a trend evolved in which only civilian and military leaders as the 'big fishes' were investigated and prosecuted, while the investigations of lower-ranking perpetrators as 'small fries' remained under the national jurisdiction (O'Brien, 2012). The president of the UN Security Council of 23 July $20022^{39}$ announced that the [CTY should concentrate on the prosecution of the leaders:

"The Council recognizes (...) that the ICTY should concentrate its work on the prosecution and trial of the civilian, military and paramilitary leaders suspected of being responsible for serious violations of international humanitarian law committed in the territory of the former Yugoslavia since 1991, rather than on minor actors."

In Sierra Leone for example, it was laid out in art. 1 of the Statute of the SCSD that:

"The Special Court shall (...) have the power to prosecute persons who bear the greatest responsibility for serious violations of international humanitarian law and Sierra Leonean law committed in the territory of Sierra Leone since 30 November 1996, including those leaders who, in committing such crimes, have threatened the establishment of and implementation of the peace process in Sierra Leone."

In the Rome Statute it is laid out in art.1: "The jurisdiction of the Court shall be limited to the most serious crimes of concern to the international community as a whole."

\footnotetext{
38 See ICC: https://www.icc-cpi.int/drc (08-08-17).

39 See "Statements made by the President of the Security Council in 2002", S/PRST/2002/21, para. 3, UN: https://www.un.org/en/sc/documents/statements/2002.shtml (08-08-17).
} 
Whereas there is no clear limitation on those with the greatest responsibility relating to war crimes, crimes against humanity and genocide (O'Brien, 2012, 528), there is a clear leadership clause for the crime of aggression (Ambos, 2010, 658), that is considered in art. 8bis(1) as crime "by a person in a position effectively to exercise control over or to direct the political or military action of a state, of an act of aggression".

Especially in case of the ICC, there are only investigations and prosecutions against the main responsible persons. Furthermore, the ICC can proceed against both states actors and rebel groups. Empirical data shows that almost half of the indicted persons are rebel leaders. One can argue that its always harder to prosecute rebels since they have no access to information as states officials would have in the cases of being indicted (Simmons/Jo, 2016, 454). This means that being state party to the ICC provides access to information, even if, or especially when, there are investigations and prosecutions against members of the own political group.

Secondly, the ICC is able to investigate states that are not a party to the ICC. This might be considered a serious intrusion into the sovereignty and self determination of the states. It means that the costs of sovereignty in becoming a state party are not much higher than in not becoming a state party, at least when seen in respect to the possibility of becoming a subject of investigation and prosecution. It could be argued that this raises an incentive for states to become a party in order to assert influence of the shape of the rules and procedures of the ICC because, in fact, they anticipate the possibility of coming under scrutiny themselves.

A third incentive in this regard is that the states parties can influence the time frame of jurisdiction. The period of time for which the ICC can investigate and prosecute crimes committed is well-defined and therefore the states whose crimes come under the jurisdiction of the ICC are able to anticipate if and when the investigation and prosecution takes place. The ICC is able to become active only in a situation after the entry into force of the Rome Statute for the respective state party (jurisdiction ratione temporis, art.11, para.1), unless there is already a jurisdiction that a state has accepted by means of a declaration under art.12(3) beforehand 40

An example of this is the ratification the Rome Statute be State of Palestine on 2 January 2015. The Statute entered into force for it on 1 April 2015. Previously, it had

\footnotetext{
40 A second option to change the time period of jurisdiction is to use the transitional provision of art. 124 as opt-out, meaning that the state does not accept the jurisdiction for a time period of seven years. Up to now, this opportunity was taken up only by France and Colombia. France withdrew in 2008 and Colombia's time period of seven years ended in 2009, see Tabak (2009). At the review conference in Kampala, one issue discussed was the deletion of art. 124, However, the Conference decided to retain the article, see Clark (2010).
} 
accepted the Statute under 12(3) since June 2014 41 So it would have been possible to perform preliminary examinations without the state having previously ratified the Rome Statute.

Fourthly, notwithstanding whether a state is party to the ICC or not, the ICC is a court of last resort. The preamble stipulates that:

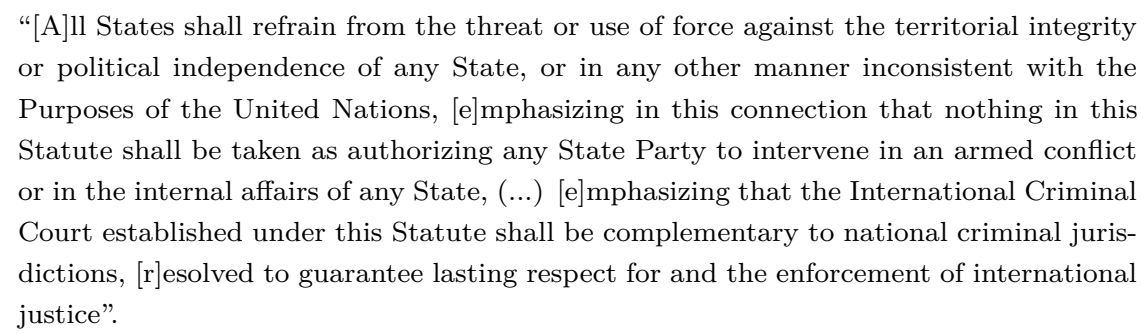

The ICC is complementary to the national jurisdiction of the states, it has to respect the sovereignty and autonomy of states and is only able to become active if a state is "unwilling or unable genuinely to carry out the investigation or prosecution" (art.17, para. 1a).

Fifthly, the ICC has jurisdiction only over the most fatal crimes that can occur in international politics: crime of genocide (art. 5, para. 1a), crimes against humanity (art. 5, para.1b), war crimes (art.5, para.1c) and the crime of aggression (art. 5, para.1d). As mentioned above the norms behind the core crimes, such as human rights or humanitarian law are much older than the ICC and are banned already at the primary level of international law. The Rome Statute brings different primary rules of conduct together and defines individual criminal responsibility. This makes it possible to enforce rules that have long standing in international law. The four core crimes integrate several legal regimes and historical experiences. The oldest among them are the war crimes. Their codification is one central component of the ius in bello (law in war) which attempts to humanize war. The law of war covers the Hague Conventions of 1899 and 1907 on permissible means and methods of warfare as well as the "Annex on Laws and Customs of War on Land", the Geneva Conventions of 1949 on the protection of persons not or no longer taking part in hostilities, such as civilians, injured combatants or prisoner 42 as well as the Protocols I-III additional to the Geneva Conventions and customary law applicable in international armed conflict. In the Rome Statute war crimes are defined as:

\footnotetext{
${ }^{41}$ However, up to 2018 there were only three submissions under article 12(3): Ukraine and both Ivory Coast and the State of Palestine before they became states parties to the ICC.

${ }^{42}$ Up until 2018196 states ratified the Geneva Convention I-IV.
} 
"(a) grave breaches of the Geneva Convention of 12 August 1949 (...), (b) [o]ther serious violations of the laws and customs applicable in international armed conflict, within the established framework of international law, (...) (c) [i]n the case of an armed conflict not of an international character, serious violations of article 3 common to the four Geneva Conventions of 12 August 1949 (...) and (e) [o]ther serious violations of the laws and customs applicable in armed conflict not of an international character, within the established framework of international law." (art. 8 Rome Statute)

Although the list of war crimes in the Rome Statute is long, by far not all of the existing war crimes of humanitarian law were integrated. Only such war crimes were selected that are part of the international customary law and can be derived from the idea of criminal responsibility (Dörmann, 2003). At the first review conference in Kampala 2010 the state parties agreed on a definition of the crime of aggression 43 as follows:

\footnotetext{
"planning, preparation, initiation or execution, by a person in a position effectively to exercise control over or to direct the political or military action of a State, of an act of aggression which, by its character, gravity and scale, constitutes a manifest violation of the Charter of the United Nations."
}

The idea behind the crime of aggression is almost as old as the war crimes themselves. Whereas the war crimes are part of the ius in bello, the crime of aggression draws on the ius ad bellum, the law to war. In the "Protocol for the Pacific Settlement of International Disputes" of 1924 was enshrined that "every State which resorts to war in violation of the undertakings contained in the Covenant or in the present Protocol is an aggressor" 44 In doing so war of aggression was declared to be a crime for the first time 45

What later came to be called 'crime of aggression' was prosecuted for the first time in the Nuremberg Trials as crimes against peace. In the "Charter of the International Military Tribunal - Annex to the Agreement for the prosecution and punishment of the major war criminals of the European Axis (London Agreement)" crimes against peace were defined as:

"planning, preparation, initiation or waging of a war of aggression, or a war in violation of international treaties, agreements or assurances, or participation in a common plan or conspiracy for the accomplishment of any of the foregoing" (art.6(3) London Agreement)

\footnotetext{
43 For further explanations on the compromise of Kampala and both definition and jurisdiction of the crime of aggression, see: (Barriga, 2010 Ambos, 2010 Solera 2010). For the pros and cons of prosecuting acts of aggression in international criminal law, see: (Paulus 2010 Kreß 2010).

44 League of Nations, Protocol for the Pacific Settlement of International Disputes, 2 October 1924.

45 For a detailed discussion on the doctrinal debate on the crime of aggression see Jeßberger (2017).
} 
In the "Report of Robert H. Jackson United States Representative to the International Conference on Military Trials" (Jackson, 1945, 294) the definition of aggression as suggested by the American Delegation is emphasized ${ }^{46}$

"No political, military, economic or other considerations may serve as an excuse or justification for such actions, but exercise of the right of legitimate self-defense, that is to say, resistance to an act of aggression, or action to assist a State which has been subjected to aggression, shall not constitute a war of aggression."

Art. 2(3) UN-Charta says: "All Members shall settle their international disputes by peaceful means in such a manner that international peace and security, and justice, are not endangered." In 1974 the UN-General Assembly adopted the Resolution 3314 and defined an act of aggression as:

\footnotetext{
"the use of armed force by a State against the sovereignty, territorial integrity or political independence of another State, or in any other manner inconsistent with the Charter of the United Nations, as set out in this Definition." (art.1, UN-Res. 3314)

"Clearly, the biggest challenge defying the adoption of a legally sound definition of aggression comes from the political unwillingness of the different actors to accept not only the idea of a workable definition of aggression, but of having a definition of the crime aggression tout court. Some States, both developing and developed, feel uneasy about further limiting their ability to wage war when the circumstances, domestic or international, so require." (Solera, 2010, 823)
}

The crime of aggression is in a certain tension with humanitarian interventions and the responsibility to protect. States that participate in humanitarian intervention are concerned that their intervention could be misinterpreted and seen as acts of aggression (Paulus, 2010). The ius contra bellum and ius in bellum have co-existed on the primary level of international law for a long time. There is hardly any reason why this co-existence should not work on the secondary level of criminal responsibility in international law (Kreß, 2010) therefore this objection to intervention while present is unconvincing.

Another concern about the crime of aggression stems from the fact that it requires an act of aggression as violation of the UN charter and thus requires state responsibility as prerequisite. Insofar that the jurisdiction of the ICC refers to the 'criminal responsibility of individuals' and not the 'responsibility of a state', there is a conflict of dual obligation. If a crime is committed by a state official or a state agent there can be a case of state responsibility (Akande/Tzanakopoulos, 2017, 33).

${ }^{46}$ For further discussion on negotiations of USA, Great Britain, France and Russia at the London Conference 1945, see Clark (2007). 
The crime against humanity, however, is less controversial and even more often the justification for humanitarian intervention. In the Rome Statute in article 7 it is defined as "any of the following acts when committed as part of a widespread or systematic attack directed against any civilian population, with knowledge of the attack":

(a) Murder;

(b) Extermination;

(c) Enslavement;

(d) Deportation or forcible transfer of population;

(e) Imprisonment or other severe deprivation of physical liberty in violation of fundamental rules of international law;

(f) Torture;

(g) Rape, sexual slavery, enforced prostitution, forced pregnancy, enforced sterilization, or any other form of sexual violence of comparable gravity;

(h) Persecution against any identifiable group or collectivity on political, racial, national, ethnic, cultural, religious, gender as defined in paragraph 3 , or other grounds that are universally recognized as impermissible under international law, in connection with any act referred to in this paragraph or any crime within the jurisdiction of the Court;

(i) Enforced disappearance of persons;

(j) The crime of apartheid;

(k) Other inhumane acts of a similar character intentionally causing great suffering, or serious injury to body or to mental or physical health.

The origins of the crimes against humanity can be traced back to the Nuremberg trials. They were designed to cover the atrocities of the German Nazi-Regime. In the London Agreement crimes against humanity were defined in art.6(c) as:

"murder, extermination, enslavement, deportation, and other inhumane acts committed against any civilian population, before or during the war, or persecutions on political, racial or religious grounds in execution of or in connection with any crime within the jurisdiction of the Tribunal, whether or not in violation of the domestic law of the country where perpetrated."

They are distinguished by the fact that they are not only crimes committed against certain people, but so cruel and odious that they can be understood as crimes against humanity as a whole. Hannah Arendt commented on the Eichman Trial in Jerusalem:

\footnotetext{
"Had the court in Jerusalem understood that there were distinctions between discrimination, expulsion, and genocide, it would immediately have become clear that the supreme crime it was confronted with, the physical extermination of the Jewish people, was a crime against humanity, perpetrated upon the body of the Jewish people, and that only the choice of victims, not the nature of the crime, could be derived from the long history of Jew-hatred and anti-Semitism." (Arendt 1963
} 
This view was reinforced in the judgment of the case Prosecutor v. Drazen Erdemovic the Appeal Chamber of the [CTY remarked 47

\begin{abstract}
"Crimes against humanity are especially odious forms of misbehavior and in addition from part of a widespread and systematic practice or policy. Because of their heinousness and magnitude they constitute an egregious attack on human dignity, on the very notion of humaneness. They consequently affect, or should affect, each and every member of mankind, whatever his or her nationality, ethnic group and location."
\end{abstract}

While the humanitarian law benefits from the logic of reciprocity (Watts, 2009), human rights hardly have inherent self-enforcing incentives, beyond the persuasion of being 'morally right' (Deitelhoff, 2006) or increasing one's reputation by committing to them (Moravcsik, 2000) 48 The creation of the crimes against humanity can be regarded as the most important of the ICC's core crimes. Beyond the creation of criminal responsibility for the most severe violation of human rights, it is stated in the Rome Statute that the interpretation and application of law has be consistent with human rights.

"The application and interpretation of law (...) must be consistent with internationally recognized human rights, and be without any adverse distinction founded on grounds such as gender [... ], age, race, colour, language, religion or belief, political or other opinion, national, ethnic or social origin, wealth, birth or other status." (art.21, para 3)

The fourth core crime is the crime of genocide in article 6, defined as:

"any of the following acts committed with intent to destroy, in whole or in part, a national, ethnical, racial or religious group, as such: (a) Killing members of the group;

(b) Causing serious bodily or mental harm to members of the group;

(c) Deliberately inflicting on the group conditions of life calculated to bring about its physical destruction in whole or in part;

(d) Imposing measures intended to prevent births within the group;

(e) Forcibly transferring children of the group to another group."

Whereas crimes against humanity focus on a very cruel killing of a large number of individuals, the crime of genocide focuses on the killing and destruction of a certain group of people. So, while crimes against humanity is intended to protect the individual, the crime of genocide is intended to protect the group. This thought and the conception of the crime of genocide goes back on Raphael Lemkin, a Polish-Jewish legal

47 Prosecutor v. Drazen Erdemovic, Joint Separate Opinion of Judge McDonald and Judge Vohrah 15-07-1999. For further examination see Akhavan (2012).

48 For more details on the different incentives structures to comply with human rights and humanitarian law see 'The Problem of Non-Compliance with International Law' on p. 43 
scholar, who wanted to find a term that describes the atrocities against the Armenians committed by Turkey during World War I as well as those against the Jewish during the Nazi-Regime in World War II (Lemkin, 1944). Based on his considerations, in the 1st session of the United Nations General assembly, which in 1946 passed the Resolution 96, genocide was declared as an international crime, that is in-commensurable with the aims and goals of the United Nations. On 9 December 1948 the "Convention on the Prevention and Punishment of the Crime of Genocide" was adopted. States that are party ${ }^{49}$ to the agreement commit themselves to prevent and to punish acts of genocide according to the collective law of state responsibility (Werle, 2007, Ambos, 2011).

For many years the genocide convention remained without impact on the international politics, since there existed no possibility of enforcement. This changed with the

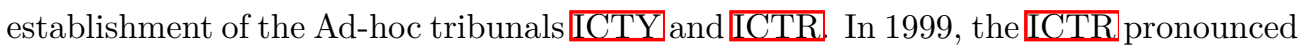
a judgment in accordance with the genocide convention (Schabas, 2000).

In summary, we can say that most of the states worldwide, at the latest after peace and security were restored after World War II, are bound to comply with the norms behind the core crimes; humanitarian law, human rights, prohibition of genocide and prohibition of aggression. Those are part of the ius cogens in international law. Additionally, some of the corresponding core agreements have high ratification rates, such as the Geneva Convention I-IV with 147 or the Genocide Convention with 196 states parties.

Up to the establishment of the Ad-hoc and hybrid tribunals it was difficult to enforce them and even when they were enforced then only to a limited degree in relation to time and place of the criminal prosecution. Combining ius ad bellum and ius in bello with the prohibition of the most severe crimes against humanity as core crimes in an international court and creating individual responsibility making it possible to investigate and prosecute can be considered a stroke of genius. This explains why many consider the establishment of the ICC as one of the biggest civilizing advances of the 20th century.

${ }^{49}$ Up to 2018 , there are 149 states i.e. several more than parties to the ICC. 


\subsubsection{Support in Dealing with the Past}

"All those who truly believe in international justice have pinned their hopes on the ICC." (Cassese 2006, 441)

The establishment of 【CT; is one of many possibilities in the context of transitional justice of coping with a past characterized by war and atrocities .

"Transitional justice can be defined as the conception of justice associated with periods of political change, characterized by legal responses to confront the wrongdoings of repressive predecessor regime." (Teitel 2003, 69)

Teitel (2003) distinguishes three phases in the genealogy of transitional justice: The first 'postwar phase' takes place in the 1940s and 1950s. With the establishment of the [MT at Nuremberg in 1945 and the IMTEE in Tokyo the foundation was laid for a legal repossessing of armed conflicts with an international criminal law.

The second 'post-Cold War phase' accompanies the 'third wave' of democratization (Huntington, 1991) in the 1970s and 1980s. It began in Western Europe with the Carnation Revolution in Portugal 1974, moved to South America and East Asia and peaked with the collapse of Yugoslavia and the Soviet Union. The establishment of several states and the transition from authoritarian military dictatorships to marketbased democracies creates the need for a conscious reevaluation of the past to promote peace and reconciliation and, ultimately, democracy (Merkel, 2004). In this political climate the term of 'Transitional Justice' emerged, based upon the assumption that the transition from conflict to peace and thereby from the perception of threat to the perception of security needs the reappraisal of past atrocities. In this time, several prominent TJ-institutions were established, such as the "National Commission on the Disappearance of Persons" in Argentina in 1983, the "International Criminal Tribunal for the former Yugoslavia" in 1993 or the "Truth and Reconciliation Commission in South Africa" in 1994. While the IMT and the IMTFE had a 'retributive' character aiming to punish crimes (Moore, 1992) the purpose of those newer TJ-instruments was to be 'restorative' by constructing an alternative history (Zehr, 2002).

The third is the 'steady-state phase' with a huge expansion and normalization of transitional justice. In the course of this, the establishment of the ICC can be considered an indicator of normalization of transitional justice by means of the investigation and prosecution of war crimes, crimes against humanity and genocide. It turns into a routine matter in international relations (Teitel, 2003, 90).

Meanwhile, there is a broad spectrum of TJ-instruments that comprise both offender orientated retribution and victim-orientated restoration of the social order pursuing 
to promote reconciliation, nation-building, democratization and peace. Accordingly, in the context of dealing with the violent past of a (post-)conflict there are several hopes and expectations in international criminal tribunals 50 a) ending global impunity and revolutionizing accountability (Sriram, 2003 Drumbl, 2007), b) peaceful conflict resolution (Moore, 1992 Akhavan, 2009), c) restoring of justice and reconciliation (Minow, 1998, Cobban, 2006), d) promoting democratization by strengthening the rule of law (Kritz, 1996, Olsen et al. 2010), d) prevention of future atrocities via deterrence effects (Wippman, 1999, Ku/Nzelibe, 2006, Weiffen, 2012, Dancy, 2017). Those effects are attributed to mechanisms of action like avoiding the apportioning of collective blame through the individualization of guilt, preventing collective myths of victimization, breaking cycles of violence and the positive effects of criminal justice on societal conflict structures (Nitsche, 2007).

The establishment of international criminal tribunals provides financial, technical and material support to states from the international community intended to help them overcome the limitations of their own national jurisdiction in dealing with past atrocities on their own.

\footnotetext{
"Today, many governments are either too weak (unable) or too involved in crimes (unwilling) to investigate and prosecute. Therefore, there is a need for an international tribunal to punish past and deter future crimes. Furthermore, the idea of universal jurisdiction is constantly gaining momentum, and even reluctant states might find that it is in their interest to cooperate with, rather than object to, the ICC." (Popovski 2000 406)
}

Olsen et al. (2010) examine the success of TJ-instruments on human rights and democracy. They argue that certain combinations of instruments, such as trials and instruments, achieve the best effects. Zero-sum solutions, as mostly discussed in the literature, lead to more harm than good.

Independent from the reason or underlying incentives that give the states cause to an international criminal court, the ICC can be considered a powerful tool among the TJ instruments. It is the only instrument that works permanently on a legal basis and can be used by all states worldwide and addresses both international and domestic audiences and raises awareness. The ICC may be regarded an attempt to learn from the mistakes of the ICTs and to create an improved institutional design.

The establishment of the Ad-hoc tribunals [CTY and [CTR was genuine improvements to the Military Tribunals [MT and [MTFE They are neither courts of victor's justice nor created by the conflict parties, but on behalf of the international community by

50 For an overview of the landscape of ICTs see e.g. Geiß/Bulinckx (2006). 
the UNSC Nevertheless, they received a lot of criticism. When the ICTY started its work, there was strong resistance from the Federal Republic of Yugoslavia, a federal state constructed by the republics of Serbia and Montenegro from the former Socialist Federal Republic of Yugoslavia. During the first proceeding: 51 the defense argued several times that the tribunal was unlawful, since an international tribunal could not be independent, if it was established by a political organ, such as the UNSC and respected the primacy of national courts (Aksar, 2005).

According to Jorda (2004, 575) both ICTY and ICTR followed the strategy of delocalization, i.e. bringing to trial the high political and military leaders at an international tribunal and leaving lower level defendants to the domestic courts. It would take too much time to prosecute every violation. This should have the positive side effect that states have to bring their domestic legislation into line with the most important principles of human rights and humanitarian law. The ICTY was blamed in certain cases for "be tempting, as it could enable victors, even well-intentioned ones, to impose 'tailor-made' justice" (Jorda, 2004, 573).

The institution design of the ICC is a result of the experiences and mistakes of the Ad-hoc and hybrid tribunals. An international court that is treaty-based instead of being established by UNSC resolutions to has a higher political legitimization, since the states have the possibility of expressing their sovereign will during the negotiations and the act of ratification (Aksar, 2005). The ICC is a permanent court, and all of its states parties can refer situations to the court any time. Thereby, "the international community attempted to cut the cord that linked international criminal justice to the critique of which previously plagued it" Kreß, 2010, 1143).

Finally, the principal of complementarity provides a greater decision-making scope for the states. The impact of the ICC as a mechanism of deterrence can be regarded as crucial in reaching its intended purpose. The potential prosecution through criminal tribunals can deter further atrocities since it reduces the cost-benefit calculations for both governments and rebel groups. Without the possibility of prosecutions, it is often a tactical decision to extend combat operations on civil population to maximize the possibility of winning an armed conflict. Thus, criminal prosecution makes it less attractive as a tactical instrument (Cronin-Furman, 2013, 443f.).

According to Dancy (2017) both the ratification of the Statute of Rome and the intervention of the ICC during preliminary examinations can lead either to 'compellence' in the sense of a direct action leading to the termination of an ongoing civil war or

${ }^{51}$ See e.g. Decision on the Defense Motion for Interlocutory Appeal on Jurisdiction, The Prosecutor versus Dusko Tadic, Case No. It-94-1-T, decision of 2 October 1995. 
to specific deterrence or general deterrence in the sense of preventing atrocities and war. Although the mandate of the ICC is not linked to an explicitly task of deterring armed conflicts, it could have an impact on armed violence. He sees three reasons for this: firstly, the ICC is permanent and thus can spring into action at every time. Secondly, the ICC often begins its investigations during conflict situations and thus can act as 'first responder'. Thirdly, he assumes that deterrence of atrocity has a positive influence on lasting peace (Dancy, 2017, 629).

Simmons/Jo (2016) see besides 'prosecutorial deterrence' moreover an important factor in 'social deterrence' that is "a consequence of the broader social milieu in which actors operate: it occurs when potential perpetrators calculate the informal consequences of law-breaking" (Simmons/Jo, 2016, 444). Those consequences can be social mobilization of domestic communities or changes in foreign material assistance. Relating to this, Dancy/Montal (2017, 657) consider the ICC as the 'shamer-in-chief', since the court multiplies the impact of media reports or the activism of nongovernmental organizations and thus "brings with it a kind of international opprobrium that is virtually unparalleled". The expected costs attached to the investigations and prosecutions by the ICC can cause states to reevaluate their human rights practice (Appel, 2018, $5)$.

In sum, the ICC brings a range of possibilities for states to receive support in dealing with the past, promoting peace or even encouraging reconciliation. Even if prosecutions fail to deter atrocities, they reinforce international norms and promote a national and international political culture that finds atrocities unacceptable (Akhavan, 1998 Wippman, 1999). Prosecutions trigger changes in the domestic legal structure that promote this (Simmons/Jo, 2016). There are several problems and dilemmas of TJ (Leebaw, 2008) revolving around the debates on 'punish or pardon' or 'peace versus justice'. The ICC provides solutions by remaining a permanent independent institution that promotes international norms that are only complementary to the existing national jurisdiction.

\subsubsection{Solving Cooperation Problems with the ICC}

In the view of $\mathbb{I R}$ theory one of the most important reasons for the commitment to international agreements, the compliance with international law and delegation of sovereignty to international courts and tribunals is the hope to solve political cooperation problems of international relations 52

52 See in the illustration of research literature on p.43 
Cooperation is defined in terms of "actors adjust their behavior to the actual or anticipated preferences of others, through a process of policy coordination" (Keohane, 1984a, 50f.). Cooperation problems appear if states get caught in a prisoner's dilemma that "embodies the tension between individual rationality (reflected in the incentive of both sides to be selfish) and group rationality (reflected in the higher payoff to both sides for mutual cooperation over mutual defection)" (Axelrod, 1980, 4).

The conclusion of legal agreements themselves can be considered as possible solutions of cooperation problems, since they provide legitimacy and enhance mutual confidence. International law can be considered as one possible form of communication and cooperation trying to agree on common norms and making promises about future behavior. International agreements codify common norms and create legitimacy of behavior and states then adhere to international rules even without control and coercion ( $\mathrm{Hurd}$, 1999). In situations that are legally regulated it is difficult to position arguments that are based only on preferences and interests. Thus, enhancing legitimacy leads to a reduction of decision-making costs. Political problems do not have to be negotiated repeatedly. They do not have to be balanced politically since there are argumentative figures and normative justifications (Abbott/Snidal, 2000).

Tying one's own hands towards the audience of domestic and international actors enhances the credibility of a state (Fearon, 1997). Newly formed democracies gain from this strategy by signaling that their political course should be taken seriously (Moravcsik, 2000). States develop a self-interest in complying with international law since the reduction of decision-making costs and the enhancement of credibility makes political situations more predictable, negotiating partners more trustworthy and solves the cooperation problems of anarchy (such as prisoner's dilemma, chicken game, battle of the sexes or tragedy of the commons).

While those mechanisms of self-enforcement via reciprocity and reputation work well in some areas of international law, such as free trade agreements (Parisi/Ghei, 2003) or the law of war (Watts, 2009), some other areas of international law, such as human rights, have weaker incentives for self-enforcement. Because there are often only informal mechanisms of monitoring and a low probability of being sanctioned, there are a lot of violations of human rights (Hathaway, 2002) which illustrates the gap between commitment and compliance (Simmons, 2009).

We can say that international law solves cooperation problems, but it also creates new ones. There are incentives for autocratic states to commit to human rights as 'empty promises' or mere 'window dressing' (Hafner-Burton/Tsutsui, 2005). This creates a 
certain uncertainty about the credibility of commitments to human rights and increases the costs for monitoring norm compliance.

With the establishment of international courts several cooperation problems of international law can be solved. Relating to the ICC as an enforcement court for humanitarian law and human rights, two central mechanisms of solving cooperation problems can be identified: a) reducing costs of monitoring humanitarian law and human rights and b) enhancing the credibility of commitments to humanitarian law and human rights.

\section{Reducing Costs of Monitoring with the ICC (Mechanism 1)}

International courts and tribunals create the opportunity of reducing monitoring costs. According to Helfer/Slaughter (2005, 35f.) international courts and tribunals highlight non-compliance and thereby decrease uncertainty about the conduct of other states. Non-compliance, in turn, creates high costs. Firstly, the probability of sanctions as a penalty for non-compliance rises, not only due to the existence of the tribunal or court itself, but also due to the multilateral political process or even unilateral politics. Secondly, a positive finding of non-compliance increases the probability of a loss of reputation. Thus, the courts create high incentives for compliance. The mere existence of the courts makes an effective monitoring possible. In the past this had been very difficult. Previously, the rules were in place, but there was no effective means of enforcing them.

What are the norms specifically monitored by the ICC and enshrined in the Rome Statute? The ICC is able to exercise jurisdiction over four core crimes that are regarded as "the most serious crimes of concern to the international community as a whole" (art.5):

(a) The crime of genocide;

(b) Crimes against humanity;

(c) War crimes;

(d) The crime of aggression.

Although those four core crime are newly defined as 'crimes' in the Rome Statute, the norms of international law and the crimes themselves are older. The respective norms for which a criminal responsibility was defined are the law to war (ius ad bellum), the law of war (ius in bello) and the prohibition of most serious human rights violations:

(a) The Genocide Convention from 1948;

(b) Prohibition of most serious human rights violations;

(c) (Hague Conventions and) Geneva Convention I-IV from 1949; 


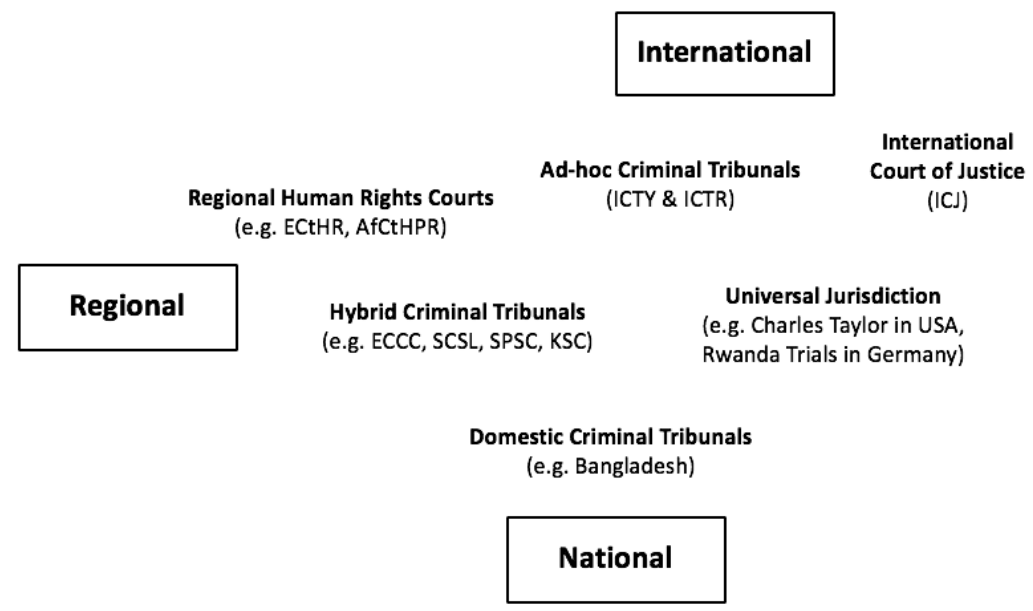

Figure 7: Monitoring Humanitarian Law, Human Rights and Int. Criminal Law

(d) UN-imperative of peaceful settlement of disputes (Ch.IV UN-Charter) and UNimperative to refrain from acts of aggression and use of force (UN-Resolution 3314).

With the establishment of the ICC as the only permanent international court able to investigate and prosecute individuals, the hope for enforcing international criminal law and deterring future violations of humanitarian law and human rights improves. It not only increases norm compliance, but integrates a system of international law that was previously decentralized and unevenly enforced (see Figure 7) 53

The oldest existing institution still monitoring humanitarian law and human rights is the International Court of Justice ICJ that was established in 1945 with the Charter of the United Nations. Its main functions are the legal settlement of disputes between the states parties to the United Nations (jurisdiction in contentious cases) and the legal advisory for the UN as international institutions (advisory jurisdiction). According to art. 36 of the ICJ Statute, the court is able to decide on all cases, which the states parties to the UN refer to it. The states parties can recognize the [C.] as a dispute settlement mechanism either by recognizing its compulsory jurisdiction or by making special provisions in other treaties and conventions.

To that effect, there are many multilateral agreements that submit to the ICJ's jurisdiction, such as the "Convention on the Prevention and Punishment of the Crime

${ }_{53}$ For a list on the several criminal courts and the regional human rights courts see Table 2 on p. 51 
of Genocide" of 1948. Up to 2017 the ICJ had tried about 150 contentious cases and held about 25 advisory proceedings; e.g. in 1993 a trial on the "Application of the Convention on the Prevention and Punishment of the Crime of Genocide (Bosnia and Herzegovina v. Serbia and Montenegro)", in 1999 several trials on the legality on the use of force in connection with the violent break up of the former Yugoslavia or on armed activities on the territory of the Democratic Republic of the Cong 54

As discussed in the subsection above on dealing with the past, Ad-hoc and hybrid criminal tribunals as well as domestic criminal tribunals were established to investigate and to prosecute international criminal law, such as war crimes or crimes against humanity. Therefore, they create criminal responsibility for individuals.

A further possibility of investigating and to prosecuting violations of international criminal law on the domestic level is based on the 'principle of universal jurisdiction' that applies independent of nationality and where the crimes were committed. According to Ambos (2011, 58ff.) the principal of universal jurisdiction can be justified by the fact that crimes such as genocide, war crimes or crimes against humanity affect not only those states in which the crimes occur or to whom victims and offenders belong, but the community of states and humankind as a whole. Their fundamental values are shaken to the core. Those state that investigate and prosecute those crimes become trustees of the community of states as a whole.

Several new emerging possibilities for monitoring human rights violations are offered by the regional human rights courts, of which there are three worldwide: the ECHR the AfCtHPR and the MCtHR Many of the international or regional organizations have internal mechanisms for monitoring compliance with human rights law. We can consider it a step forward that there are so many possibilities to bring violations of humanitarian law and/or human rights to court. However, the ubiquity of monitoring and the concurrency of different judicial bodies able to try violations of humanitarian law and human rights can lead to problems like forum shopping or a clash of legal decisions.

All of the judicial institutions mentioned above struggle with serious problems. The International Court of Justice is repeatedly confronted with harsh criticism because many judgments were never put into practice, such as in the La Grand Case. The judges are accused of not being impartial and deciding instead in favor of their home countries (Posner, 2004). Notwithstanding the empirical evidence supporting those

${ }^{54}$ For detailed information on the list of cases referred ti the ICJ since 1946, see: http://www .icj-cij.org/docket/index.php?p1=3\&p2=2 (12-06-2017). 
criticisms, we can state that the ICJ is in a very difficult position. In principle, it is available to every state for every issue on international law.

The regional human rights courts deal primarily with human rights violations in times of peace. Since they are regional, they are only available for a limited group of states 55 The concurrency of those monitoring mechanisms creates high cost, especially for those states that are involved or particularly active in multiple institutions. Seen in this light, the establishment of the ICC centralizes the previously decentralized monitoring of humanitarian law and human rights. It makes it possible to enforce their norms on a permanent international level. For the states engaged in international relations this leads to a reduction of monitoring costs that occur normally as a consequence of participating in multiple monitoring strategies concurrently. Those states that were politically and financially involved in several of the monitoring institutions can benefit considerably from the ICC. They can save expenses in the long run. Conversely, the ICC as an institution can benefit in the processes of both normative development and institutional learning.

Appel (2018) is of the opinion that we can expect an improvement in human rights practice through the ICC since it poses costs to leaders, such as losing domestic and international support that benefits them militarily and economically. This can be observed empirically. Although states with a good human rights practice are more likely to ratify the Rome Statute, it can be observed that the human rights practice of states parties continue to improve. This is not the case for non-party states to the ICC.

\section{Enhancing Credibility with the ICC (Mechanism 2)}

Apart from the intended purpose of creating an international institution that monitors and enforces the norms behind the core crimes of the ICC, we can expect states to delegate sovereignty to the ICC to enhance the credibility of their commitment to those norms. Therefore, they are able to solve the cooperation problem of a lack of credibility.

"On way legalization enhances credibility is by constraining self-serving auto-interpretation. Precision of individual commitments, coherence between individual commitments and broader legal principles, and accepted modes of legal discourse and argument all help limit such opportunistic behavior. Granting interpretative authority to courts or other legal institutions further constraints auto-interpretation." (Abbott/Snidal 2000, 427)

55 The ECHR has 47 states parties (states of the European Council), the AfCtHPR has 30 states parties and the IACtHR 23 states parties (Organization of American States (OAS)). 
Majone (2001) is of the opinion that "the most important reasons for delegating powers (...) are two: to reduce decision-making costs, for example by taking advantage of executive branch expertise, or to enhance the credibility of policy commitments". He argues that the strategy to delegate to certain agents is dependent on the respective reason for delegation. When reducing decision making costs the problem of bureaucratic drift can arise, i.e. the outcomes of delegation can deviate from the initial reason for delegating power. Therefore, principals should delegate to agents with similar policy preferences. Following the logic of enhancing credibility, principles should delegate to an agent with dissimilar policy preferences (Majone, 2001, 103f).

Astonishingly, the strongest proponents of human rights agreements are often neither great powers nor established liberal democracies, but newly emerged democracies. These have the strongest need and thus the greatest interest in protecting their new political status quo against the threats of autocratic or repressive forces. They commit to human rights agreements to signal their interests and increase their credibility (Moravcsik, 2000, 219f.).

Simmons (2009) builds on this assumption and argues that governments would not gain much benefits from disingenuous commitment to arbitrary international agreements. Even if their monitoring is weak, there are several actors in international relations, like other governments, or international civil actors that care about the compliance of the norms and collect information on the compliance behavior.

\footnotetext{
"[E]xpressive support does not occur in a political vacuum. It triggers political consequences by raising the consciousness of potential stakeholders and giving them a salient moral and legal claim on the realization of that right. In the absence on any intention of of following through, the risks of such position-taking - the demands and expectations it is unlikely to stimulate - are likely to equal or perhaps even to exceed what can only be short-term benefits. It is possible that governments miscalculate the extent to which they will end up being held accountable (...), but they run risk of apolitical backlash in response to blatant inconsistency." (Simmons 2009, 60)
}

In a broad empirical analysis, she tested several influencing factors on the ratification behavior of states towards human rights agreements. Contrary to the conventional wisdom that governments with the closest preferences to the agreement would be most likely to ratify, she demonstrated that newly transitioned democracies are most eager to commit to human rights agreements. She considers this as an indicator for the thesis that not only political preferences are important factors for commitment, but also the historical context.

She describes the same effects for the states' commitment to the Rome Statute. We can observe that many autocratic or transformative states ratified the Rome Statute. 
Simmons/Danner (2010) assume that states are often unable to commit themselves credibly and thus have difficulties in reaching cooperative solutions. Political promises are often not enough to make the political vis-a-vis believe one would behave in the way promised. What is needed is to increase the costs of defection in a cooperative game. If a court is able to prosecute violations of the negotiated norms like the ICC, it becomes possible to show that their own hands are tied. Thus, credibility becomes enhanced both on the international and the domestic level:

\footnotetext{
"What kinds of ex post costs might a government face for reneging? Legally, ratification to the ICC statute is a commitment made formally to the international community. As such it can trigger a potentially costly investigation, prosecution, and punishment of government officials or agents. But ratification also involves domestic audience costs by raising expectations among the general populace weary of violence that the government is committed to diffusing the conflict and seeking peaceful solutions. The frustration of these expectations by the commission of atrocities is likely to cost the government popular support." (Simmons/Danner 2010, 234)
}

Simmons/Danner (2010) see the commitment to the ICC by becoming a state party being dependent on two central determinants: the existence of a recent violent history and a certain weakness of the state's rule of law 56

Beyond the concrete support transformative states get from TJ-activities, the commitment to strong TJ-instruments, such as the ICC, is a possibility of increasing their political commitment. This is a chance to prove themselves as trustworthy in the international system, showing themselves to be a reliable partner for future cooperation in trade and politics. It is a signal towards domestic actors, be it opponents or proponents. Ratifying international agreements influences the political agenda, the litigation of domestic courts and thereby the mobilization of civil society. Simmons $(2009,108)$ draws the conclusion that international law matters, and human rights change politics. They even goes so far to say that governments ratify human rights agreements because they intend to comply with them. And in the case of the ICC the states can use their commitments to step forward making peace by enhancing the credibility of commitments.

\footnotetext{
56 Simmons/Danner (2010) distinguish between three groups of states with different incentive structures: a) States with a violent recent history, but a weak domestic rule of law to come to terms with the past by themselves (e.g. Peru or Afghanistan or) that are likely to ratify the Rome Statute because they need the support of the ICC; b) states with a violent recent history and a strong domestic rule of law coping with it by themselves (e.g. USA or India) that are not likely to ratify the Rome Statute because they are able to come to terms with the past by their own; c) states without a violent recent history and a strong rule of law (e.g. Norway, Sweden or Germany) that are likely to ratify because they do not have to fear negative consequences.
} 
"The ICC is not the obvious place to engage in purely symbolic gestures; governments have plenty of opportunities to make symbolic gestures in international law by ratifying the numerous treaties devoid of external enforcement provisions." (Simmons/Danner 2010 , 254)

In sum, we can regard the ratification of the Rome Statute as a great deal. Almost all states are nevertheless bound to the international law behind the core crimes (UNrequirement of peaceful settlement of disputes, law of war, human rights law and prohibition of genocide). The institutional design of the Rome Statute sets clear limits on the jurisdiction of the ICC and the consequences of being a state party to the ICC are foreseeable 57 The principle of complementarity makes the ICC a solution of last resort and provides that there will only be investigations and prosecutions if the states are unwilling or unable to carry out proceedings on the national level. The costs of sovereignty are rather low, while there can be great benefits of increasing international and national security, such as the privileges of being states parties, getting support in dealing with the past, and above all solving cooperation of international law.

In the worst-case scenario, a state has to surrender a few of its citizens that committed one or more of the worst crimes of humankind, which are neither tolerated politically nor permitted legally. The ICC promises nothing less than protecting peace, security and well-being in international relations, while respecting state sovereignty and national criminal jurisdiction functioning as a last resort.

The costs incurred of a political sovereign delegating power to the ICC seem rather small at first glance, while the benefits seem highly promising. The ICC presents a real opportunity to end global impunity and prevent severe violations of human rights, humanitarian law and acts of aggression. Viewed in this light, it becomes less surprising that states bind themselves to the ICC, in particular those states that need the support of the ICC dealing with a violent past. Put in a nutshell: the establishment of an enforcement court cuts monitoring costs, reduces the probability of future norm violations and increases and reduces the uncertainty of the behavior of other states in international relations. This is most probable if the main function of a court is to enforce international law. However, the extent to which states commit to the ICC varies very widely. This is based on the fact that in spite of all benefits, there are reasons nevertheless why states have to fear the ICC.

\footnotetext{
57 For some legal scholars the narrow definitions of the core crimes, in particular of the crime of aggression, raises the concern that a behavior of states that does not fall within the a criminal responsibility would be automatically legal. Therefore, the primary rules of conduct through international law and secondary rules of criminal responsibility should be clearly distinguished; see e.g. Paulus (2010).
} 


\subsection{Why States Have to Fear the ICC - Obstacles in Ratifying}

\subsubsection{Missing Institutional Counterparts}

In contrast to the previous considerations, the following thesis can be proposed: Since the ICC is not able to protect the states from violations of humanitarian law or human rights, or at least war crimes, genocide, crimes against humanity or the crime of aggression, states do not bind themselves comprehensively to the ICC. Instead, they selectively delegate small parts of their authority to the ICC in order to retain enough power and authority to protect themselves from other states.

Before illustrating this in detail, the question why is the ICC not able to protect the states must be answered. It is the job of the ICC to protect the states from war crimes, genocide, crimes against humanity or aggression. But it is rather a court of last resort according to the principle of complementarity. Another plausible answer is that the ICC would not be able to protect the states, since it stands alone in international relations missing those institutional counterparts a court needs in order to do its work in a system of separation of powers.

On the international level several international and regional bodies are labeled as 'courts', having both their formal characteristics and their symbolic attributes. According to Shelton (2009, 4ff.), international courts have the guarantee of independence and the control of their procedures. Nevertheless, they differ strongly in their functions and their inherent powers compared to national courts.

Those judicial powers are: a) the compétence de la compétence meaning that courts have to decide about the legality of the dispute and thus the exercise of jurisdiction 58 b) courts should have the power to issue interim measures in respect to the subject of the dispute; c) courts should have the capacity to generate and appreciate facts, since a good fact-finding mechanisms enhances the legitimacy and the credibility of a court and many international courts have the power to write their own rules of evidence and procedure 59 d) courts should have the power to raise relevant questions of law to develop international law in the context of the specific cases (deciding the merits); e) the judgments and sentences of international courts should be legally binding for the parties and courts should be able to refer to previous interpretations and judgments (finality and binding nature judgments). The Rome Statute stipulates: "The Court may apply principles and rules of law as interpreted in its previous decisions" (art. 21, para. 2 Rome Statute).

58 An overview of the jurisdiction of international courts is to find in Amerasinghe (2002), esp. ch. 5. 59 In the case of the ICC the power to write the rules of evidence remained at the states themselves. 
The miscellaneous international courts and tribunals can have different functions in international relations. The enforcement of law is only one among them. Others would include dispute settlement (e.g. the Dispute Settlement Body of the WTO), legal advice (e.g. the International Court of Justice) or monitoring compliance (e.g. Regional Human Rights Courts). Although there is an overlap between the functions and some courts fulfill more than one of them, each has one dominant function that influences its mandate. Taking into account what the function of a court is, we can better assess what power it has and which challenges it has to overcome (Shelton, 2009, 8ff.). International Courts that have the function of dispute settlement, such as the [C.] ITLOS or the DSB of the WTO are supposed to inhibit escalation of conflicts and the use of self-help and reprisals to further international peace and security 60

They have to provide fair opportunities for the states parties and give advice for the settlement of the dispute on the basis of the agreed legal rules. At most dispute settlement bodies, the parties can voluntarily end the litigation, provided that they agreed to do so (Shelton, 2009, 9).

International courts that monitor and support compliance, such as the regional human rights courts [ECHR [ACtHR and AfCtHPR, are supposed to interpret and apply particular agreements. They decide cases that are brought before them and safeguard and develop the respective norms and rules. Their aim is to prevent future violations and to raise the protection of human rights rather than to redress single violations. The cases before compliance courts are maintained up to the end, regardless if the parties want to do so.

Most international courts have the competence of giving legal advice. The IC.J is even able to give legal advice to any legal question, since "the jurisdiction of the Court comprises all cases which the parties refer to it and all matters specially provided for in the Charter of the United Nations or in treaties and conventions on force" (art 36, para. 1 ICJ Statute) ${ }^{61}$ The ICJ is supposed to identify, interpret and apply international rules and principles giving assistance to international legal issues (Shelton, 2009 13f).

$\overline{60}$ Establishing an international court is not the only possibility of settling international disputes peacefully. Other forums are e.g. arbitrary tribunals like the 'London Court of International Arbitration' since 1891 or the 'International Chamber of Commerce' since 1919; installing mixed claim commission like the 'Iran-US Claims Tribunal' since 1981; or establishing fact-finding commissions e.g. in the context of human rights like the 'International Commission of Inquiry on the Syrian Arab Republic' since 2011 or the 'South African Truth and Reconciliation Commission' 1996-1998 in the context of transitional justice.

61 According to art. 36 ICJ-Statute states can recognize the jurisdiction of the ICC in general (compulsory jurisdiction) as 72 states have done (state of 01-17), or they can determine its jurisdiction in particular agreements (treaty based jurisdiction). 
Courts with the function of enforcement are supposed to determine innocence or guilt of persons that are accused of having committed certain crimes, such as the ad-hoc Tribunals ICTY and ICTR, the hybrid criminal tribunals like the SCSL or SPSC] or the ICC. This aims to enforce certain norms of international law and prevent future violations by the effect of deterrence. Therefore, crimes deriving from those norms have to be defined in detail and the court has to ensure that the jurisdiction is not frustrated and the judicial character is maintained (Shelton, 2009, 12f).

International law can be regarded as a huge hodgepodge of agreements, charters, conventions, covenants, declarations, protocols and treaties. International law does not inevitably need coercion or the use of force (by means of e.g. retaliation and retorsion) to ensure compliance. Compliance can be achieved through several mechanisms, such as reciprocity (Keohane, 1984a), reputation (Simmons, 1998, Moravcsik, 2000) or persuasion (Deitelhoff 2006). If there is the decision to establish an international court to investigate and prosecute at the level of individual criminal responsibility, we can assume those mechanisms are not sufficient to ensure norm compliance. The law requires a court to make enforcement possible. However, if enforcement is necessary to guarantee the compliance of law, then force is necessary to enable the function of enforcement.

We can consider the ICC as enforcement court. With the definition of the four core crimes - war crimes, genocide, crimes against humanity and the crime of aggression - it creates a criminal responsibility for several already existing norms on the primary level of international law, such as the UN-requirement of peaceful settlement of disputes, the law of war, human rights and the prohibition of genocide. Of course, monitoring norm compliance is also an important function that the ICC fulfills. However, all possible ways of triggering investigation and prosecution require arguments and information about probable core crimes committed. Those are provided - dependent on how jurisdiction is triggered - from the states concerned, the UNSC or the civil society. We could say that the ICC initiates and furthers the monitoring of the norms indirectly, while it fulfills the function of enforcement of the norms directly.

The preamble of the Rome Statute states that the ICC is created "to guarantee lasting respect for and the enforcement of international justice". The enforcement of international law requires not only the judicial power to interpret the legal norms and to decide on penalty in cases of norm violations, but also an executive power that is able to enforce rulings and sentences. This can be considered a transfer of the domestic logic. Criminal courts are part of a democratic system of separation of powers, at the level of international relations. 
That courts function as part of a rule of law in order to end the state of war and achieve peace and security in international relations is borrowed from the thoughts on states and the social contract (Doyle/Carlson, 2008). Thomas Hobbes stressed the links between anarchy and insecurity, and respectively, between state and security. He considered individuals as self-interested actors, driven by 'competition, distrust, and glory', living in a state of nature in which a 'war of all against all' prevails. This state endures even in times of the absence of actual war, since all have to protect their own liberty and safety against possible attacks of the others (Leviathan, Part I, Ch.13). The only way out of this hostile state of nature is the delegation of "power and strength on one (...) so as to turn all their wills into a single will (...) [the] great LEVIATHAN" (Leviathan, Part I, Ch.17) for the purpose of creating security (Leviathan, Part I, Ch.21). He further states: "And covenants without the sword are merely words, with no strength to secure a man at all" (Leviathan, Part I, Chapter 17).

According to Doyle/Carlson (2008, 652ff.) this thought can be transferred on the international level, where states are considered as self-interested actors that are driven by competing for material goods and prestige and the fear that the others may conquer their territory. In a Hobbesian world states seldom experience security, but live with the permanent threat of war. They end in war if one is much stronger than another or if one does not recognize the power and prestige of the other. Compliance with international rules is possible, especially in the shape of the ius ad bellum to protect against war and the ius in bello to regulate war. States comply with it if they have to fear retaliation or they have common interests with other states. However, the greatest problem is that weak states are not protected from strong states in the absence of a global Leviathan.

Due to the liberal thought of John Locke, the father of modern constitutional states, individuals are rational, equal and independent, living in an peaceful state of nature, being determined and restricted only by the natural law (para 4) that requires not "to harm another in his Life, Health, Liberty, or Possessions" (para. 6). Thus, everybody is engaged and obliged to sustain him or herself and the humankind as a whole (para. 6). As long as the individuals comply with the natural law, a peaceful cohabitation is possible even without political rule. However, not everybody complies with that natural law and therefore individuals have the rights to punish violations (para.8). This right to self-defense can lead to a state of war (para.16). A society can only exist, if there is the power to protect the property of individuals and if all individuals have given up their natural power and thus their right to punish crimes by themselves (para. 87). 
"Those who are united into one Body, and have a common establish'd Law and Judicature to appeal to, with Authority to decide Controversies between them, and punish Offenders, are in Civil Society one with another." (para. 87) (Locke, 1967 [1689], 342)

Thus in a society there is legislative, judicial and executive power:

"And herein we have the original of the Legislative and Executive Power of Civil Society, which is to judge by standing Laws, how far Offenses are to be punished, when committed within the Commonwealth; and also to determine, by occasional Judgments founded on the present Circumstances of the Fact, how far Injuries from without are to be vindicated; and in both these to employ all the force of all Members, when there shall be need." (para. 88) Locke 1967 [1689] 343)

Legislative power is defined as follows:

"The Legislative Power is that, which has a right to direct how the Force of the Commonwealth shall be employ'd for preserving the Community and the Members of it." (para. 143) (Locke 1967 [1689], 382)

Furthermore, he stresses the importance of the executive power.

"But because the Laws, that are at once, and in a short time made, have a constant and lasting force, and need a perpetual Execution, or an attendance thereunto; therefore 'tis necessary there should be a Power always in being, which should see to the Execution of the Laws that are made, and remain in force.And thus the Legislative and Executive Power come often to be separated." (para. 144) (Locke, 1967 [1689], 382f.)

The protection requires a functioning system of separation of powers. However, obviously, in international relations, such a separation of powers does not exist. Although an 'international criminal court' - a term that suggests applying to all states worldwide - was established there is no international executive power, in which all states worldwide are represented 62

The need to secure property and freedom seems to have shifted from a an inner-state level to an international level, enhancing the legalization of international relations. Nevertheless, the institutionalization of an international security is still in its infancy. This is reflected in the paradox that especially in institutions that are strongly legalized or judicialized, states tend to fall back into demonstrations of power. This can be rooted in the fact that international courts, such as the ICC, are missing institutional counterparts in international relations. Tomuschat (2010) stresses that the

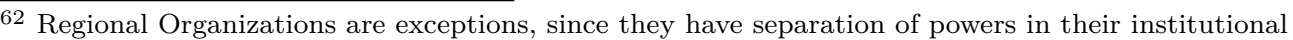
design. The EU e.g. has a separation of legislative (EU-Parliament and Council of the EU), judiciary (European Court of Justice) and executive (European Commission) powers.
} 
absence of such counterparts weakens the institutional structure of international courts and gateways for hijacking for political interests can arise. Whereas the cooperation with the legislative power (making law) and the executive power (enforcing law) is essential for international courts (dispensing law) to fulfill their role, and lastly to act independently they should not engage in politics.

Helfer/Slaughter (2005) for example admit, too, that their argument that delegation enhances credibility is circular, as there is no global authority to enforce a state's promise to cooperate:

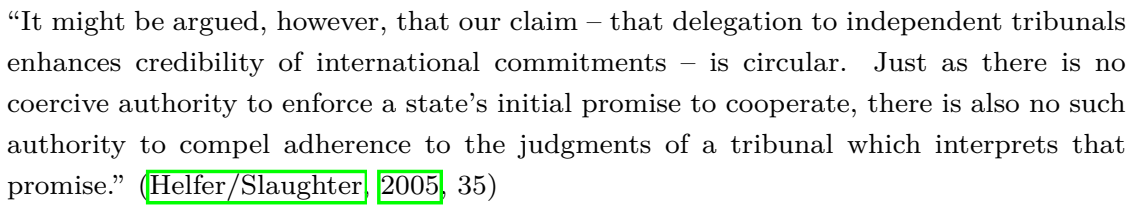

In the case of the ICC, we cannot say, there is no executive power. There are institutional counterparts, such as the Assembly of States Parties and the Security Council of the United Nations. Nevertheless, we can consider the executive power to be distorted to some extent, insofar as it is not always obvious, who the main executive power is. It is decisive, who makes political decisions with respect to the ICC.

According to article 112 of the Statute of Rome the Assembly of the States Parties accompanies and supports the work of the ICC. It is composed of one representative per state, who may be accompanied by advisory staff (art.112 (1) Statute of Rome). The tasks of this board are e.g. deciding the budget for the Court, deciding the number of judges, deciding about cases of non-cooperation and the supervision of the Presidency, the prosecutor and the Registrar of the Court (art.112 (2). The Assembly has its own "Bureau consisting of a President, two Vice-Presidents and 18 members elected by the Assembly for three-year terms" (art.112 (3) a Statute of Rome).

The Assembly of States Parties is the legislative body of the ICC and has moreover the management oversight. According to article 112, the ASP consists of both one representative for every state party and their respective deputies and advisers. States that did not ratify, but signed the Rome Statute, are allowed to send observers to the ASP It has a bureau consisting of a president and two vice presidents as well as 18 elected members.

Its' responsibilities include the management oversight, considering reports and activities of the Bureau, considering and adopting recommendation of the Preparatory Commission, deciding the budget of the court, deciding about the number of judges and considering cases of non-cooperation (art.112 para.2). The ASP meets about 
once a year and each state has one vote. The aim is to reach decision by consensus. If this cannot be reached, decisions require a two-thirds majority of the present states, whereas the quorum is reached with an absolute majority of the states (art.117 para. 7) 63

The relationship of the ICC and the UN-Security Council is much more complex. The UNSC has several privileges and obligations towards the ICC. 64 The preamble of the Rome Statute stipulates that the ICC acts according to the UN-Charter. The states parties are:

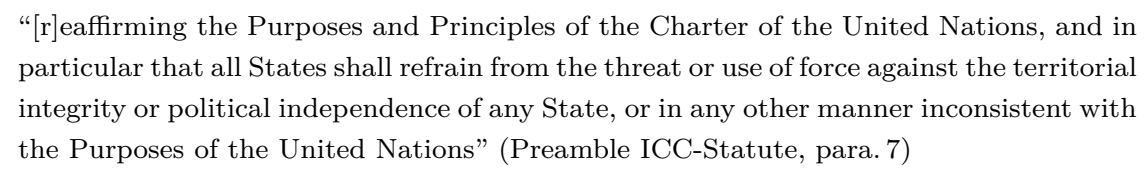

According to article 13 (b) (exercise of jurisdiction) the ASP has the right to refer situations to the ICC and thereby initiate investigations as took place in the situations of Sudan/Darfur (UN-Resolution S/RES/1593 in 2005) and Libya (UN-Resolution S/RES/1970 in 2011). During the process of negotiating the institutional design, it was highly disputed to authorize the UNSC with this possibility (Pinchon, 2011, 8): Proponents of the UNSC's right to refer regarded it as a chance to have an alternative to the establishment of ad-hoc tribunals (Arsanjani 1999), while opponents feared that those rights would undermine the credibility and independence of the ICC (Williams/Schabas, 2008).

According to article 16 (deferral of investigation or prosecution) the UNSC is allowed to request the ICC (under chapter VII UN-Charter) to defer investigations or prosecutions for a period of 12 months. The background of article 16 is the concern of the UNSC that the jurisdiction of the ICC could clash with ongoing conflict resolutions with UN peace-keeping missions. Accordingly, it was discussed to exclude the jurisdiction of the ICC over situations under consideration by the UNSC. Since many states feared this would undermine the ICC, a compromise was reached that provided that the UNSC can adopt a resolution to request a 12 month deferral from the ICC (Arsanjani, 1999. 26f.).

In 2004 the UN-ICC Relationship Agreement (UN-ICC RA) was concluded. Herein, it is emphasized that the ICC acts as an independent institution and both institutions recognize the status and mandate of each other (art.2 UN-ICC RA). They agree

\footnotetext{
63 In the case of payment arrears for at least two years a state has no vote (art. 117 para. 8).

64 The UNSC is composed by the five permanent veto powers (France, Russia, China, USA, Great Britain) as well as ten non-permanent members that are elected for two years.
} 
to cooperate closely and consult each other on matters of common interests (art. 3 UN-ICC RA). If a state party or a non-state party that has entered into an ad-hoc agreement fails to cooperate, the ICC may inform the UNSC, if it has brought the matter to the court, according to article 87 (requests for cooperation). As laid down in article 115 (funds of the court and the ASP), the ICC receives grants from the UNSC subject to the approval of the UN-GA, in those cases that are referred to the ICC by the UNSC Since the adoption of the Kampala Amendment, the rights of the UNSC within the ICC was even broadened to some extent. The crime of aggression is defined as:

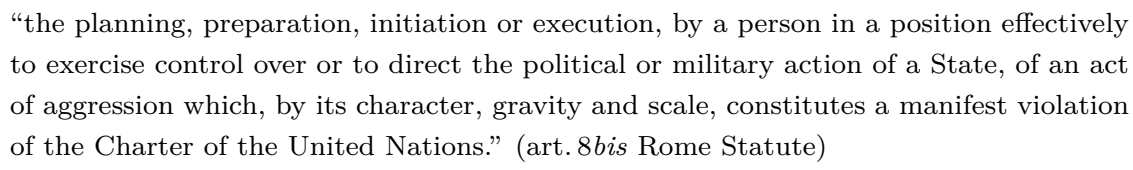

For the exercise of jurisdiction over a crime of aggression referred to the ICC, by state referral or proprio motu, it is laid down that the UNSC can make a determination of an act of aggression.

\footnotetext{
"Where the Prosecutor concludes that there is a reasonable basis to proceed with an investigation in respect of a crime of aggression, he or she shall first ascertain whether the Security Council has made a determination of an act of aggression committed by the State concerned. The Prosecutor shall notify the Secretary-General of the United Nations of the situation before the Court, including any relevant information and documents." (art. 8 bis, para. 6 Rome Statute)
}

If such a determination has been made, the ICC is able to start its investigations (art. 8bis, para. 7). If no determination is made after six month, the ICC can proceed investigation nevertheless (art. 8bis, para. 8) and it is stressed that: "A determination of act of aggression by an organ outside the Court shall be without prejudice to the Court's own findings under this Statute" (art. 8bis, para. 9 Rome Statute). Thus, a crime of aggression has to be in concordance with the UN charter and to some extent one can consider the ICC Chief-Prosecutor to be supervised by the UNSC, which can be considered to be an executive authority.

We can conclude that the legislative power lies in the hand of the ASP. Nevertheless, the behavior of the UNSC in the case of the Resolution 1422 shows that the UNSC snatches legislative decisions, too (Heselhaus, 2002, 914). We can assume that the ASP accepts this because the ICC is dependent of the support of the UN, especially of the UNSC, to enforce legal decisions and to hold states accountable to cooperate with the ICC (art. 87 ICC-Statute). In this sense, the UNSC is to some extent part of 
the executive power of the ICC, too. Particularly insofar as it has to make political decisions to maintain international peace and security in international relations while the ICC itself is bound by legal interpretations of the Rome Statute

A huge part of executive power lies to some extent still in the hand of the states (parties) themselves. This can be explained with several aspects: Firstly, the Rome Statute emphasizes the complementary character of the ICC and thereby recognizes the sovereignty of the states. Secondly, the Rome Statute recognize the principles of the United Nations, particularly the territorial integrity and the political independence of the states. Thirdly, the states play an important role in the enforcement of the sentences and rulings of the ICC, such as the terms of imprisonment in the prisons of the states parties (art.103 of the Rome Statute). In the logic of the law following the Lockean thinking, only the executive power is allowed to use force to sanction violations of law. However, as shown above, we cannot clearly say in which hand the executive power lies, but in a sense it is spread amongst ASP UNSC and the states themselves. The former judge and president of the ICTY Jorda is of the opinion:

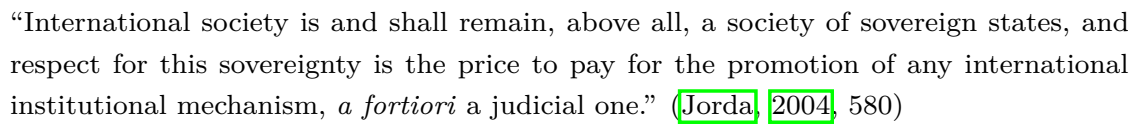

It becomes clearer that states tend to constrain their commitments to the ICC as they try to keep up strategic spaces to react on unforeseen events, especially since every state know, that states parties do have diverging interests towards the ICC, as they have different benefits of becoming state party to the ICC. We can consider the establishment of international courts as an attempt of transferring the international relations into a liberal system, with the striving for peace, security and rule of law. Still, in the sense of Hobbes, we are missing a global Leviathan in international relations. Outside of the EU, a supranational enforcement is non-existent. While there is enforcement to some extent, as in the UNSC, political ambitions and problems of collective action are often so strong that "enforcement [is] late, inadequate, or lacking completely" (Simmons, 2008, 200).

In the Lockean thinking of liberalism we can assume states only commit and obey to international law if the power guarding it is able to respect the states and to protect their autonomy and security.

65 "In order to ensure prompt and effective action by the United Nations, its Members confer on the Security Council primary responsibility for the maintenance of international peace and security, and agree that in carrying out its duties under this responsibility the Security Council acts on their behalf" (art. 24(1) UN Charter). 
"For all Power given with trust for the attaining an end, being limited by that end, whenever that end is manifestly neglected, or opposed, the trust must necessarily be forfeited, and the Power devolve into the hands of those that gave it, who may place it anew where they shall think best: for their safety and security. And thus the Community perpetually retains a Supream Power of saving themselves from the attempts and designs of any Body, even of their Legislators, whenever they shall be so foolish, or so wicked, as to lay and carry on designs against the Liberties and Properties of the Subject." (para. 149) (Locke 1967 [1689] 385)

When becoming a state party to an international court such as the ICC, states have to delegate sovereignty. If the court is not able to protect them, the risk becomes too high and they have to retain a space for political space strategy for self-defense in both domestic and foreign politics. In that respect, the benefits of delegating power to the ICC are limited. Since the ICC is a court of last resort, states cannot expect the ICC to protect their autonomy, safety and property reliably and sufficiently. Most of the states cannot afford to delegate sovereignty to the ICC unreserved, since they need to retain a political space that is big enough to be able to protect themselves for the case that the ICC cannot or will not help them.

We can resume that submission needs democratic incentives or autocratic force. If a political power is not able to protect those it is superior to, the inferior does not have sufficient incentives to submit comprehensively and to obey to the law. For the ICC this means that the court itself is not able to protect the state from war crimes, genocide, crimes against humanity or aggression. Furthermore, it is missing clear institutional counterparts, especially an executive that would be able to ensure such a protection, following instead the principle of complementarity. And exactly because of this, the states do not have enough reasons to submit comprehensively.

This is aggravated by the instable situation of the ICC, which can not only lead to uncertainty of protection on the part of the court, but also the ICC itself can be perceived as a risk of security, if it turns out to be too weak to shield trials of politicization of particular interests of powerful states, or if it turns out to be too strong for the states in order to ensure the complementarity. The court's paradox occurs especially in institutions in which states that have strong judicial institutions fall back into a demonstration of power.

Thus, the states have to fear that the ICC is too weak to cope with those power ambitions and particular interests or becomes too strong towards the sovereignty of the states, acting as an own political player and in the worst case, going out of control of the states (see Figure 8). 


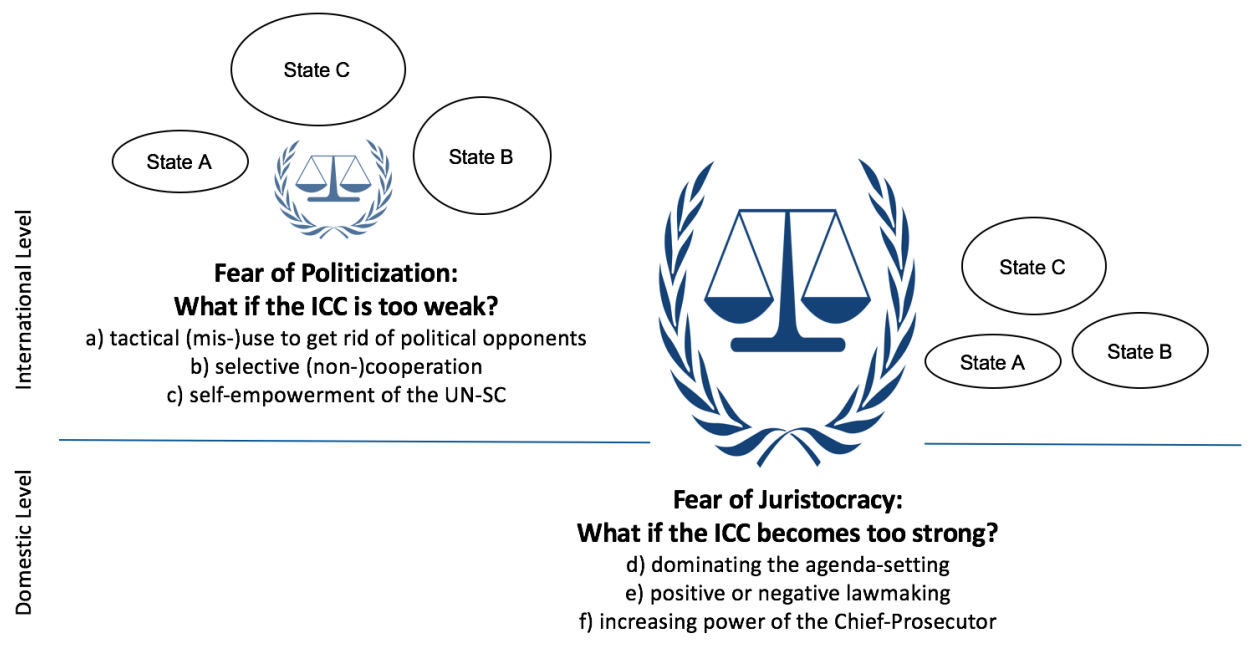

Figure 8: Fear of Politicization and Juristocracy

\subsubsection{What if the ICC is too Weak? Fear of Politicization}

Even though the ICC is a court of high independence, it has to overcome the challenge of cooperating with and concurrently bearing up against the UN-Security Council, against the governments of the ASP and their domestic veto-players and especially against the states that are not party to the ICC. Being aware of this charged relationship, many states worry about the power and performance of the court, and most of all, its ability to protect itself against politicization in the sense of (mis)using its institutional design for political particular interests. What if the ICC is too week to withstand the manifold interests and preferences of political actors in international relations?

Three consequences or at least indicators of the ICC being too weak are broadly debated in the political academic discourse: a) the tactical (mis) use of the ICC to get rid of political opponents, b) the selective (non-)cooperation of the states for own political interests, c) the self-empowerment of the UNSC as gatekeeper of the ICC. Additionally, a subsequent discourse related to the above mentioned tactical (mis)use of the ICC falls under hijacking the argument of politicization shielding oneself against the ICC.

There is fear of politicization of the ICC if there is a case of a) tactical (mis) use to delegitimize the political opposition. This fear, however, is not new. 
Even during the time of the ancient Greeks war criminals were prosecuted. Those war tribunals were mainly national or local and often ineffective, even if those that were responsible for the war crimes remained in power and prosecuted the political opponents (Schabas, 2011, 1f). To this day, a certain fear of 'victor's justice' remains and there are still several political and academic voices that express the concern of exploiting international criminal courts tactically to get rid of political opponents.

Subotic (2009) speaks of the phenomenon of 'hijacking justice', meaning that TJinstruments have become such a popular way of coping with past atrocities, that some states use them to get rid of political opponents or to gain membership in an [10 or Regional Organization (자), such as the $\mathbb{E U}$ She argues that those who truly believe in social change and international norms often have no influence on the political decisions of such (post-)conflict states, while those actors which have influence often act strategically for their own political purpose. As an example, she refers to the ICTY and the Srebrenica massacre. Most of the people in the former Yugoslavia would have considered it as victor's justice to hold international trials against some individuals. Most of the perpetrators still live free. People would have only agreed because this was a condition for EU candidacy ${ }^{66}$

Claude Jorda, former judge at the ICTY said:

"This is the specificity, as well as the ambiguity, of international courts that refuse victors' justice: a delicate balance must be struck between political realism and absolute justice. From this perspective, the truth is evident: international courts must accommodate themselves to the political environment, whether we like it or not." (Jorda, 2004. 579)

However, the concern of victor's justice must be taken into perspective, since there is huge debate on whether only the 'big fish', meaning civilian or military leaders shall be prosecuted or also the 'small fries', meaning the lower-ranking perpetrators. Since the ICTY was in the beginning of its work criticized for prosecuting too many lower ranking perpetrators, both ICTY and ICTR have been urged to concentrate on the 'big fish' (O'Brien, 2012). Thus, we have to take into account that the feelings of being blamed or wronged as a nation arises from the fact that often only the leading military and civilian personnel are accused, due to the development of the principle at all international criminal courts, that not every violation of severe human rights or humanitarian law lead to international criminal responsibility. But rather only the big war-criminals-bosnias-republika-srpska (17-02-2017). 
fishes are prosecuted. Thereby there is a certain clash of the perspectives of the victims and the considerations on the restrictions of feasibility of international criminal law. Although there are good reasons for prosecuting only chiefly responsible persons and limiting the jurisdiction to a certain time frame, according to Jetschke (2011), this can create some unintended incentives for different domestic actors to choose between different instruments of transitional justice. As a consequence it is possible to observe that amnesties are likely if the superior conflict group is in government, while criminal trials are most likely if the former inferior conflict group is in government. In the case of the ad-hoc and hybrid tribunals, we can observe that the probability of establishing criminal trials is highest if the former defeated party is in government, while granting amnesties is probable if the superior party is in government.

During the development of the institutional design of the Rome Statute, one central issue was to try to prevent victor's justice and contain the potential danger of a strategical establishment of a court to get rid of undesirable opponents. This was done by establishing a permanent court and by having different possibilities of triggering investigations and prosecutions. Indeed, if we have a look at those cases that came to the ICC by state-referral (art.14), we can observe a clear pattern.

Cassese (2006) stresses that in all situations that are referred by states, the conflicts concerned are domestic and most of the crimes were committed by rebels, such as in the Democratic Republic of the Congo, Uganda, Central African Republic and Mali. However, in those situations that are referred by the UNSC (e.g. Darfur/Sudan) or initiated proprio motu by the Chief-Prosecutor of the ICC (Kenya, Libya, Ivory Coast) there are investigations even against states officials. He argues that states are unlikely to accuse officials of other states. He refers to Alberico Gentili, a scholar of civil and international law in the 17th century, who said: "diaboulus non vexat", i.e. the devil does not torment the devil, which again refers to Aristotle's "canis caninam non est", i.e. a dog does not eat a dog (Cassese, 2006, 435). Thus, we see a tactical usage by the states to cope with domestic opponents. We must admit that this would speak in favor of the ICC strengthening the position of states, if they must struggle with civil wars or civil commotions, they could not deal with by themselves.

A second concern about politicization (as result of the ICC being too weak) is $\mathbf{b}$ ) selective (non-)cooperation of states for political reasons. In an interview in 2014, the former Chief-Prosecutor of the ICC, Fatou Bensouda said:

"[W]e should at all costs prevent the Court from being politicized. We should continuously and always be guided by the evidence and the Rome Statute legal framework. 
These alone, not any other consideration, guide the Office's actions." (Bensouda, 2014

3)

There, she referred to the fact that since the ICC concentrates on the persons responsible mainly for crimes committed, often heads of state or heads of militia are accused, such as Thomas Lubanga (ICC-01/04-01/06), former leader of the militia UPC (Union des Partrioes Congolaise); Muammar al-Gaddafi, former President of Libya (ICC01/11-01/11); Laurent Gbagbo, former President of Ivory Coast (ICC-02/1101/15) or Uhuru Muigai Kenyatta, President of Kenya (ICC-01/09-02/11). However, because of their position and their political power, those persons are often protected by the army or the state apparatus and it is hard to gather information and evidence. Lastly, it is very difficult to obtain their surrender as in the case of Omar al-Bashir in Darfur (ICC02/05-01/09). We can consider coping with the politically motivated noncooperation of the states concerned as a serious challenge.

A third concern about politicization (as result of the ICC being too weak) is the c) (self)empowerment of the UNSC as gatekeeper of the ICC. As mentioned above, the ICC as the judicial power with the ASP as the legislative power is missing a clear executive counterpart. Unless the states can be considered as the executive power, the UNSC is at least a part of the executive power. It is able to refer situations to the ICC, even if the states are not party to the Rome Statute. Moreover, the UNSC may mobilize the pressure of the UN in cases of noncooperation that are seen in the obstruction of the ICC's investigations and prosecutions or the non-recognition of sentences.

We can say that the UNSC plays a paramount role in the ICC regime. On one hand, the ICC needs the support of the UNSC to increase the legitimization of investigations and prosecutions to put pressure on the enforcement of the rulings. One the other, the ICC is a potential gateway for politicization. Since three (China, Russia and the USA) of the five veto-powers have not ratified the Statute of Rome, it provides a certain wiggle room not only for the world powers, but also for non-party states of the ICC. A possible broadening of the rights of the UNSC as could arise from jurisdictional rules of the crime of aggression, is widely considered as problematic.

Paulus (2010) warns against the expansion of the prerogative of the UNSC within the ICC-regime referring to the jurisdiction of the crime of aggression:

"[D]o we really want to make prosecution of one of the gravest crimes dependent on a political body in which the great powers have veto power to shield themselves and their allies entirely from prosecution? As the brief history of the ICC has shown, the Security Council will not refrain from using its prerogatives under Chapter VII and article 103 of 
the Charter to claim precedence over the ICC, as has already happened when it shielded UN forces from the jurisdiction of the Court." (Paulus 2010 1125)

He refers inter alia to S/Res/1422 from 2002, where the UNSC requested the ICC to defer from investigation and prosecution, if officials or personnel from a non-party state of the ICC act in UN peace-keeping operations.

" 1. Requests, consistent with the provisions of article 16 of the Rome Statute, that the
ICC, if a case arises involving current or former officials or personnel from a contributing
State not a Party to the Rome Statute over acts or omissions relating to a United Nations
established or authorized operation, shall for a twelve-month period starting 1 July 2002
not commence or proceed with investigation or prosecution of any such case, unless the
Security Council decides otherwise;

2. Expresses the intention to renew the request in paragraph 1 under the same conditions each 1 July for further 12-month periods for as long as may be necessary". S/Res/1422

The background of the resolution was the veto of the USA against the prolongation of the UN operation in Bosnia-Herzegovina, with the justification that the USA would not risk a politically motivated prosecution of their military personnel. The Resolution 1422 could be considered as 'blank immunity' for non-party states operating in UN peacekeeping mission, since those do not have to request the ICC in a particular case, but are excluded in any arising case. This is notwithstanding the fact that there is a concrete danger that non-party states would not take part in a certain UN mission. After the enactment of the Resolution 1422, the USA withdrew its signature of the Rome Statute pursuing to not violate the prohibition of obstructing the execution of the agreement (Heselhaus, 2002).

With regard to the jurisdiction of the crime of aggression, there is the concern that the UNSC uses its prerogatives to decide if there will be investigations and prosecutions or not, since it is allowed to determine a crime of aggression. However, this is no condition for exercising jurisdiction (Ambos, 2010, 664ff.), but rather a 'jurisdictional filter' (Barriga/Grover, 2011, 523). The major role of the UNSC concerning triggering investigations and prosecutions Kreß (2010) acknowledges the critique of Paulus (2010):

With the birth of the ICC, the international community attempted to cut the cord that linked international criminal justice to the critique of 'victor's justice' and 'policy in the disguise of law' which previously plagued it. Adherence to the principal of equal application of law must now be considered as a minimum requirement of legitimacy for a system of permanent international justice. To subject the ICC to the veto power of the permanent members of the Security Council falls foul of meeting this basic requirement (Kreß 2010 1143). 
A further discourse, as variation of politicization can be identified that can be described as hijacking the fear of politicization in order to protect themselves against the ICC or even as justifying the narrative to fight the ICC. The aforementioned concerns about politicizing the ICC by unintended effects of the institutional design, such as the tactical usage of investigations, the non-cooperation for political reasons and the gate-keeping of the UNSC must be clearly differentiated from political debates that increase those concerns hyperbolically in order to blame the ICC as a Trojan horse of politicization and, thus, as a danger for international relations.

There are several examples in which, ironically, heads of states that are opposed to the ICC accuse the court of being highly politicized and therefore not worth supporting. However, those accusations did not come up in political fundamental debates, but in certain political situations, in which there is reason to argue that they act like this to undermine the ICC in order to avert negative consequences for the own state or the own political group. Respectively, we can consider those narratives as an instrument to undermine the legitimization of the ICC, justifying their evasive behavior regarding the ICC.

One example is that the USA blames the ICC of being a threat for peacekeeping operations and humanitarian interventions. As discussed above, the USA justified its veto during the debates on a prolongation of the UN peacekeeping operation in Bosnia-Herzegovina (UN-MIBH) with the concern that US-soldiers could be in risk of politically motivated prosecution by the ICC (Heselhaus, 2002, 907). However, at this time (spring 2002), the USA had only one troop deployed for UN peacekeeping and this was stationed in Ethiopia/Eritrea (UNMEE) and not in Bosnia-Herzegovina in $\mathrm{UN}-\mathrm{MIBH} 67$

In general, we can observe that the USA are surely the largest donor for UN peacekeeping operations. For the time frame of June 2016 until July 2017, the USA donated $28.57 \%$ of the $\$ 7,81$ billion budget for peacekeeping operations 68 Interestingly, the number of troops deployed to UN peacekeeping operations is in general relatively small 69

\footnotetext{
67 See country contributions detailed by mission, available under: http:

//www.un.org/en/peacekeeping/resources/statistics/contributors_archive.shtml (26-01-17).

68 Among the main contributors are: 1. United States (28.57\%), 2. China (10.29\%), 3. Japan (9.68\%), 4. Germany (6.39\%), 5. France (6.31\%), 6. United Kingdom (5.80\%), 7. Russian Federation (4.01\%), 8. Italy (3.75\%), 9. Canada (2.92\%), 10. Spain $(2.44 \%)$. See A/70/331/Add. 1, Implementation of General Assembly resolutions 55/235 and 55/23, available under: http://www.un.org/en/ga/search/view_doc.asp?symbol=A/70/331/Add.1 (26-01-17).

69 In the annual statistics of the UN peacekeeping the contributions per country are calculated for military and civilian police. To rank only the troops deployed data has to be garnered directly
} 
In July 2005, the USA contributed 10 troops of 59,329 that were stationed worldwide in UN peacekeeping operations and thereby ranked 53th. In July 2010 it was 16 troops of 83,899 worldwide (rank 64) and in July 2015 it was 28 troops of 91,151 worldwide (rank 74). In the same month in which after all the prolongation of UN-MIBH was decided in S/Res/1423 on 12 July 2002, the Rome Statute entered into force and the ICC started its work. Viewed in this light, the US concern on politicized prosecutions of US soldiers seemed to be a justification narrative blaming the ICC, for whatever the true reasons were.

Another example, that is even harsher, is the accusation from some African states that the ICC is a '(neo-)colonial instrument of imperialism'. This allegation was supported by the fact that all eight situations under investigation between 2002 and 2012 took place in African State: 70 We can put this into a global comparative perspective in that the African continent suffers notably from many armed conflicts.

Further, among the African states many more ratified the Rome Statute than Asian States. Half of the situations were referred by the states themselves. There are indeed several efforts of the ICC outside the African continent, such as in Columbia since 2004, Iraq/UK 2006 or Afghanistan since 2007. In those cases the ICC carries out only preliminary examinations and until now those efforts were less well known to the global public. Perhaps this is why the allegation of the ICC being (neo-)colonial instrument of imperialism attracted widespread attention.

Several states of the African Union have criticized the ICC of being a tool of Western powers. In a speech to the AU on 12 October 2013, Kenya's President Uhuru Kenyatta urged the African states to withdraw from the ICC. He called the ICC a 'tool of Western powers' and emphasized that the true friends of Kenya would be the USA, China, India, Russia, Brazil and South Africa. Most of these states are not parties to the ICC, except for Brazil and South Africa. Kenyatta was supported by several other African leaders, particularly from President Kagame of Rwanda, President Museveni of Uganda, and Prime Minister Desalegn of Ethiopia 7

These heads of states all are autocratic, all have a very violent recent past. Rwanda and Ethiopia States are not even party to the ICC. Thus, we can see that the blaming of the ICC was rather used as a justification narrative for acts of non-cooperation or

from the monthly listed statistics. This is broken down into civilian police, military observers and troops.

70 DR Congo (ICC-01/04), Uganda (ICC-02/04), Darfur/Sudan (ICC-02/05), CAR I (ICC-01/05), Kenya (ICC-01/09), Libya (ICC-01/11), Ivory Coast (ICC-02/11) and Mali (ICC-01/12).

71 See Makau W. Mutua in the New York Times, 5 November 2013: http://www.nytimes.com/2013/11/06/opinion/kenya-tests-international-justice.html (24-01-17). 
even to lay the groundwork for legitimization of a possible future withdrawal from the ICC.

A further example of seeking to avoid the negative consequences of investigations and prosecutions is the allegation from some voices in Israel that the ICC would promote terrorism and be used as a 'tool of legal warfare'. On 1 January 2015, the State of Palestine accepted the jurisdiction of the ICC under art.12(3) over crimes committed in the Palestinian territory including East Jerusalem since June 2014 and then acceded to the Rome Statute, now being a regular state party to the ICC 72

This step was criticized from many sides as a threat to the peace-building process between Israel and Palestine. Israel reacted with outrage and Foreign Minister Liebermann requested several states to cancel the financing of the ICC. According to newspaper reports, he called the ICC a political institution that no longer has a right to exist. Prime Minister Netanjahu described the decision of the ICC initiating preliminary examinations as absurd immediately following the terrorist murder of Jewish civilians in Paris 73

The White House under Obama expressed the opinion that Palestinians would not be eligible to join the ICC because they would not constitute a state. Establishing a permanent state would be a violation of the Oslo Accords 74 In TheTrumpet, an US-magazine of the Philadelphia Church of God the spokesman of the Israeli Foreign Ministry, Emmanuel Nahshon, was cited:

\footnotetext{
"The Palestinians have started a legal warfare, which is not useful to peace, and we call upon the Palestinians and also upon the important members of the international community to make sure that this will not happen. At the end of the day the Palestinians may easily find themselves on the bench of the accused at this international tribunal since the Palestinian Authority is now in a national unity government with a terror organization." Emmanuel Nahshor 75
}

However, we have to take the argument from Nahshon into perspective, because a state referral (be it under art. 14 or under art. 12(3)) is only possible if there is a state.

\footnotetext{
72 Making those two steps in two succeeding days is reasoned with the fact that the declaration under article 12(3) was written yet on 13 June 2014, first day of the third Gaza war.

73 See 'Die ZEIT', 18 January 2015: http:

//www.zeit.de/politik/ausland/2015-01/nahostkonflikt-israel-boykott-strafgerichtshof (25-01-2017).

74 See Palestinians and the International Criminal Court, New York Times, 24 June 2015: https://www.nytimes.com/2015/06/25/world/middleeast/ palestinians-and-the-international-criminal-court-what-you-need-to-know.html (08-08-2017)

75 See the speech of Emmanuel Nahshon available in 'The Trumpet' at: https://www.thetrumpet. com/article/12355.19.0.0/israel-palestinians-started-legal-warfare-by-joining-icc (08-08-2017).
} 
When taking the view that Palestine is not considered a state, then the ICC would not be able to initiate a preliminary examination. In that sense, the referral of Palestine can be considered an instrumentalization of the ICC as it strengthens the narrative of Palestine being a sovereign state. This however leads us to another fear towards the ICC, raising the question: What if the ICC becomes too strong?

\subsubsection{What if the ICC is too Strong? Fear of Juristocracy}

There is fear that the ICC could become a puppet on a string in the hands of political forces. In the worst case scenario, their very own political opposition could act as puppeteer, and thereby instrumentalize the ICC. Conversely, what if the ICC becomes too strong and starts to act as an own political player that makes its own decisions and, in the worst case, goes beyond the control of the Assembly of States Parties?

These considerations must not necessarily contradict the points above, e.g. the misuse of the ICC weakening the opposition. They do have in the first instance another point of departure for their arguments. Rather than worrying that the ICC is too weak, they consider the court an unassailable, powerful actor in international relations. In the last three decades, we find, mainly in the literature on constitutional courts, but increasingly also in the literature on regional and international courts, the concept of a 'judicialization of politics', i.e. more and more courts restrain the scope for action in politics or even make politics (Vallinder, 1995, Stone Sweet, 1999. Shapiro/Stone Sweet, 2002). Already in 1981, Shapiro describes a growth of political jurisprudence, meaning that courts deviate from the prototype of a court. He speaks of 'uncourtlike courts' behaving 'like other political actors' (Shapiro, 1981, 1). Likewise, Vallinder (1995) finds that 'the courts go marching in'.

In the context of the debate on the concept of 'global governance', law becomes one central instrument alongside power, economy and civil society. The increasing importance of law leads to a process of global constitutionalization beyond the state, and thus to an, albeit incomplete, global rule of law (Zangl/Zürn, 2004, Zangl, 2009). Hirschl (2008) is of the opinion that beyond the judicialization of constitutional courts there is an increasing judicialization of mega-politics. He sees three phenomena being described by the concept of judicialization: the spread of legal discourse and jargon into the political sphere, the expansion of judges and courts determining public policy outcomes and the emergence of judges and courts dealing with mega-politics, meaning political debates that influence whole polities. 
"[T]he judicialization of politics is often treated as obvious byproduct of the global convergence toward constitutional supremacy and the prevalence of rights discourse. What is more, the judicialization of politics is often used indiscriminately to refer to what in fact are several distinct phenomena, these range from judicial activism and rights jurisprudence to debates over judicial appointment and the politicization of the judiciary - the inevitable flip side of judizialization." (Hirschl 2008, 120)

In the issue area of transitional or restorative justice for example, he sees the Ad-hoc and hybrid tribunals as well as the ICC as important examples of a judicialization of mega-politics in international relations. Moreover, he refers to domestic institutions as the quasi-judicial truth commissions, e.g. in the post-apartheid era in South Africa or the newly created constitutional courts in in the post-communist era of Europe playing an important role in restorative and transitional justice. In the Czech Republic for example, the constitutional court decided in 1993 that the entire Communist era was illegal (Hirschl, 2008, 127f.). He describes this phenomenon as 'juristocracy', meaning the new global constitutionalism and the judicialization of 'mega-politics' (Hirschl. 2004, 169ff.).

There is a danger, that Guzman (2013) calls the 'Frankenstein Problem'. It means that states create international organizations to promote both international cooperation and own political interests. However, the organization could become too strong and the risk arises of it doing harm that outweighs the potential benefits it offers.

\footnotetext{
"States, then, face what I term the 'Frankenstein problem' when they create IOs. By creating a new entity states hope to address some common problem. Once created, however, the new entity has a life of its own and cannot be fully controlled by individual states. Importantly, there is a direct trade-off between the need to give the IO enough authority to be effective and the desire to guard against the risk that it will become a monster." (Guzman 2013 1000)
}

In case of the ICC, we can identify at least three aspects of a possible 'juristocracy' becoming a Frankenstein: raising the fear of the states (parties) that the ICC could become 'too strong' and thus overstretch its actual tasks: d) international courts dominating the political agenda setting, e) positive or negative lawmaking by international courts, and f) the increase of the power of the ICC-Chief-Prosecutor.

Firstly, there is the concern about d) international courts dominating the agenda setting. In the case of the ICC, this refers to appropriate tools of peace-building, peacekeeping and democratization and the potential use of different instruments of transitional justice. In the field of research of transitional justice, there is a controversial debate on the establishment of courts and tribunals instead of granting amnesties. 
We can expect the ICC to have deterrent effects in stopping ongoing civil wars, preventing the future outbreak of war and atrocities $\sqrt{76}$ as well as providing support in dealing with the past 77 Nevertheless, there are critical voices claiming that the ICC in becoming too strong could displace other ways of building peace or dealing with a violent past. There is a peace-versus-justice-debate on being cautious with too many criminal prosecutions as local needs have to be considered (Hazan 2006) as well as leaving room for tactical concessions during peace negotiations.

Snyder/Vinjamuri (2003) go one step further and argue that the prosecution of atrocities is a risk leading to new atrocities because it pays insufficient attention to local political situations. Since international criminal courts often suffer from the lack of cooperation of both the powerful international key states and the states were the atrocities happened, it is questionable if the strategy of prosecution is successful. They consider amnesties as more effective in facilitating peace-building and political reforms. While the prosecution of past abuses inflame the conflicts, amnesties are an appropriate tool to allow a peaceful negotiation between the conflict groups, making it possible to arrive at justice later. This follows their formula: "Justice does not lead; it follows" (Snyder/Vinjamuri 2003, 6), meaning that a political order must be established upon the bargaining of the political groups and administrative institutions have to be created to enable law enforcement.

Ginsburg (2009) shares the view, emphasizing however, that it is better to make pragmatic decisions to build peace and security, instead of blundering into a trap of moral hazards that occur if states follow the incentive to avoid peace deals because of the fear of being prosecuted: "In a world with 194 sovereigns it may sometimes be preferable to leave the decision to the local actor rather than require blanket prosecution in every available case." (Ginsburg, 2009, 509). Sands (2016, 381) summarized it as follows:

"[It] poses a serious challenge to our system of international law confronted with a tangible tension: on the one hand, people are killed because they happen to be members of a certain group; on the other, the recognition of that fact by the law tends to make more likely the possibility of conflict between groups, by reinforcing the sense of group identity."

In the worst case the ICC encourage leaders to fight harder. This is reasoned in the fact that negotiating a peace agreement can mean a risk of being punished for the atrocity committed and thereby continuing to fight and prolonging the conflict can become a rational alternative (Dancy/Montal, 2017, 656).

\footnotetext{
${ }_{76}$ Interestingly, between 1998 and 2017 there began 79 new armed conflicts in non-party states and only 13 in party states of the ICC (Dancy, 2017, 650ff.).

77 For the benefits of the ICC in dealing with the past see on p. 85
} 
There are scholarly debates as to which TJ-instrument is better for achieving peace and if international criminal tribunals lead to deterrence of future crimes. However, we have to recognize that in the view of the states it can be a problem if the agenda setting of peace-building and transitional justice is dominated by international criminal law. Sometimes other TJ-instruments seem more desirable for either normative reasons or because of rational benefits.

Furthermore, there are concerns about the extent to which courts influence policy outcomes and the legitimization of the judicial power through e) international courts as (negative or positive) lawmakers. In the case of international criminal law, the development of the legal norms took place concurrently starting in Nuremberg and continuing until Rome. Danner (2006) argues that only states have the authority to make law, but with the proliferation of international courts and the growth of their importance, courts and judges tend to make law. She sees one pivotal indicator in the fact that UNSC decides to enforce the law of war as interpreted by temporarily restricted international criminal tribunals.

\footnotetext{
"The interaction between international criminal law and the laws of war suggests the importance of international judicial lawmaking, illustrates the powerful role that temporary institutions can play in the development of international norms, and underscores the importance of theoretical models of international relations that account for changes in states' preferences over time. (...) [S]tates often tacitly delegate lawmaking authority (...), [but] (...) do not acknowledge this delegation, however, in order both to perpetuate the fiction of state hegemony over international norm generation and to provide a shield behind which international courts can make law without suffering paralyzing political pressure that would negate their ability to do so." (Danner, 2006, 3ff.)
}

She holds the view that judicial lawmaking is most likely when the norms behind it are old and the political conditions have changed, and it is less probable that there will be a treaty revision. Between 1945 and 1997 the USA can be considered as a dominant proponent of enforcing international criminal law. In a speech, US President Bill Clinton said:

\footnotetext{
"At Nuremberg, the international community declared that those responsible for crimes against humanity will be held accountable without the usual defenses afforded to people in times of war. (...) In the years since Nuremberg, the hope that convicting those guilty of making aggressive war would deter future wars and prevent future crimes against humanity, including genocide, frankly, has gone unfulfilled too often. (...) No peace will endure for long without justice. (...) Only justice can lift the burden of collective guilt. (...) Only justice can assign responsibility to the guilty and allow everyone else to get on with the hard work of rebuilding and reconciliation." (Clinton, 1996, 10ff.)
} 
However, since the USA was outvoted in 1997, they became one of the hardest opponents to the ICC. Actually, they wanted a court within the legal regime of the United Nations, that is subordinate to the UNSC. Thus, the hostility of the United States to the ICC cannot be explained sufficiently with the argument of protecting their own nationals from prosecutions. After all, [CTY, [CTR and SCSD had jurisdiction over US-nationals. According to Schabas (2004), the reason they reject the ICC is simply that it is not subject to the power of the US as a permanent member of the UNSC. In 2000, Clinton made a statement at the US signing of the Rome Statute, saying:

\footnotetext{
"We do so to reaffirm our strong support for international accountability and for bringing to justice perpetrators of genocide, war crimes, and crimes against humanity. We do so as well because we wish to remain engaged in making the ICC an instrument of impartial and effective justice in the years to come. (...) In signing, however, we are not abandoning our concerns about significant flaws in the Treaty. (...) Signature will enhance our ability to further protect U.S. officials from unfounded charges and to achieve the human rights and accountability objectives of the ICC." (Clinton, 2000)
}

It might be a further explanation for the US objections to the ICC that international courts like the ICC shape international norms and politics on their own and they fear the ICC becoming too strong. It is seen as an institution that could become a danger for the US hegemonic claims, setting the global agenda and deciding over the appropriateness of norms and the admissibility of ways and means, as we can see in the selectivity of humanitarianism and humanitarian intervention (Moyn, 2014, 35ff.). Moreover, there is the problem of 'dual obligation'. Although the ICC has jurisdiction to determine 'criminal responsibility of individuals' and not the 'responsibility of a state' it makes indirectly statements on state responsibility, in particular if a crime is committed by a state official or a state agent (Akande/Tzanakopoulos, 2017, 33):

"[A]ll the 'core crimes' are not addressed merely to individuals but are also related to the same (or substantially similar) obligations imposed on states. The prohibition on genocide is addressed both to individuals and to states; war crimes are serious violations of international humanitarian law, which is clearly binding on states; and crimes against humanity are derived essentially from human rights law."

This means for the states that they have to be cautious that the investigation or prosecution of individual civilians does not lead to major state responsibility and thus to larger consequences.

A further attribute of the independence of international courts is 'compétence de la compétence', i.e. a court is able to decide in case of doubt on the own jurisdiction (Shelton, 2009). In the Rome Statute, the compétence de la compétence is laid down 
in article 18 [Preliminary rulings regarding admissibility] and article 19 [Challenges to the jurisdiction of the Court or the admissibility of a case].

One can consider the 'compétence de la compétence' of the ICC insofar as restricted, as it is not able to determine its own rules and procedures. Usually a court has the right to determine its own rules on procedures rather than writing its own rules of evidence. In the case of the ICC, the states decided that, although the court is able to determine its own rules of evidence, the power to determine the rules of procedure remains with the states themselves. Interestingly, the predecessor ICTY had the right to determine those by itself 78

This could be an indication of minimizing the 'strategical space' of the court (Steinberg, 2004) or of 'constrained independence', according to Helfer/Slaughter (2005). That is reasoned in the fear the ICC could overstretch its mandate. We can consider the development of law even through the courts themselves as necessary for a legal regime.

\footnotetext{
"More generally, the judicial function is to apply existing, recognized rules or principles of law to the questions before it, but these rules and principles have to be developed, adapted, modified, and interpreted in the context of specific cases because all systems of law are incomplete. In the drafting of international agreements, states sometimes decide to reduce the negotiation costs and risk of defection by allowing deliberate ambiguities to remain in the text." (Shelton, 2009, 6f.)
}

There are also concerns on $\mathbf{f}$ ) the expansion of privileges of the chief-prosecutor and the possibility of civil society sending communications. There is a broader debate in the literature on judges of both constitutional courts and international courts becoming too strong. In the context of constitutional courts, many scholar consider "judges as 'players' in the policy game because of the separation of powers" (Shepsle, 2010), being important veto-players (Hönnige/Brouard, 2017). Many scholars see the reason for judicial politics in the behavior of the judges as similar to politicians. Stone Sweet (2002) states for the judges of the US Supreme Court:

"Since the Court generally deals with the 'trouble cases', it is typically called upon to decide precisely those questions for which neither the existing body of law nor the ither agencies of government have been able to provide a solution." (Stone Sweet, 2002, 25)

Shepsle (2010) is of the opinion:

\footnotetext{
78 Article 15 of the ICTY Statute says: "The judges of the International Tribunal shall adopt rules of procedure and evidence for the conduct of the pre-trial phase of the proceedings, trials and appeals, the admission of evidence, the protection of victims and witnesses and other appropriate matters." (Shelton, 2009, 6).
} 
"As central players in important political institutions, judges are politicians; yet their links to 'constituencies' are attenuated by the fact that, through lifetime tenure, they don't need to have their contracts renewed by those constituencies at regular intervals." (Shepsle 2010,474)

Although the term of office at international courts is usually limited, judges are often accused of pursuing a political agenda, mostly those of their home states, at the international level. Posner/Figueiredo (2005) are of the opinion that despite of the rise of states parties and possibilities of legal action, the usage of the ICJ became increasingly rare. They argue that this is caused by the fact that the [C.] is strongly influenced by the political interests of those states which dispatch the judges:

"[I]f judges identify with their countries, they may find it difficult to maintain impartiality. International Courts of Justice judges are not only nationals who would normally have strong emotional ties with their countries; they also have sent their careers in national service as diplomats, legal advisors, administrators, and politicians." (Posner/Figueiredo, 2005 608)

In the contrary reading, we could argue that it would be very hard for the judges of the ICC to act according to their nations of origin own interest, not to mention that there are hardly any arguments for why they should want to do so. We can expect them to be acting as servants of the international law itself. Particularly, lawyers that work at international courts as judges or even as chief prosecutors usually look back on a long career at different international courts. Nevertheless, we cannot deny that there are some decision-makers at the governments of the states (parties) that have concern that particular judges gain to much influence.

\footnotetext{
"International judges clearly do face political limitations, but the biggest constraint is neither the lack of a world state, nor the lack of string coercive tools. Indeed, it really is not clear that adding either of these features would change the reality that international judges, like all judges, are legally and politically constrained." (Alter 2014, 8)
}

If there is any gateway for legal overstretch through judges in the case of the ICC, it is the possibility of triggering investigations proprio motu (art.15) or according of an UNSC referral (art.13b). Of course, we can argue that the initiation of investigations by the Prosecutor is no legal overstretch, since this capability is set out clearly in the Rome Statute. An UNSC referral is more problematic. This should only occur if there is a grave breach of international peace. However, notwithstanding the question of how far a legal overstretch of the ICC takes place or could take place, we can expect states being concerned about this potential danger. 
In his statement on the US signature of the Rome Statute President Clinton explained the objections of the USA indirectly with the strength of the Chief-Prosecutor:

"In particular, we are concerned that when the Court comes into existence, it will not only exercise authority over personnel of states that have ratified the Treaty, but also claim jurisdiction over personnel of states that have not. With signature, however, we will be in signature, we will not." (Clinton, 2000)

According to Schabas (2004) the USA is opposed to this because the Rome negotiations did not result in the level of control that they wanted, especially more control through the UNSC. This is one of the reasons that states fear that the ICC would become too strong.

"Though the Court must not appear to be a paper tiger, as it takes its first steps, the Prosecutor's criminal justice policy must be tactfully made clear, such that the Court seems neither the zealous guardian of a political balance not of its jurisdiction, nor the intransigent censor of an as-yet unspecified world order." (Jorda 2004 580)

The fear of the ICC becoming to strong through the role of the Chief-Prosecutor is to some extent aggravated by the fact that the Chief Prosecutor is only possible to trigger investigations proprio motu "on the basis of information on crimes within the jurisdiction of the Court" (art.15 para.1).

After examining the information he or she received "from States, organs of the United Nations, intergovernmental or non-governmental organizations, or other reliable sources that he or she deems appropriate, and may receive written or oral testimony at the seat of the Court" (art.15 para. 2). It can be argued that political costs of committing to international agreements can be considered as especially high if the agreement empowers the citizens of the state to mobilize against their own state, either through implications for the national legal system or by having established a channel for raising audience (Simmons, 2009, 67f.). The threshold condition of receiving 'communications' from i.a. non-governmental organization makes the ICC even more powerful towards the states and the principle of complementarity is undermined to some extent. 


\subsection{States Constrain and Customize their Commitments to the ICC}

\subsubsection{The Delegation Dilemma of States: Ratification or Not?}

The considerations above have shown that there are both strong opportunities and high risks when ratifying the Rome Statute and becoming a state party to the ICC. There are several strong incentives for different kinds of states to become a state party to the ICC. The first permanent criminal court can be considered a milestone in international relations. It strengthened the monitoring and enforcement of humanitarian law and human rights law by creating criminal responsibility for their most serious violations by determining innocence or guilt of the individuals accused and in preventing future violations by the effect of deterrence (Shelton, 2009) for those crimes that "threaten the peace, security and well-being in international relations" (Preamble Rome Statute).

The states which are usually already bound by large parts of humanitarian law and human rights, receive several privileges when becoming a state party to the ICC, such as the participation in the development and running of the court. For (post-)conflict states the ICC is a chance to receive help and support in dealing with past atrocities to establish or strengthen peace and democratization (Hughes/Thakur, 2007).

International criminal courts and tribunals are created to increase the enforcement of humanitarian law and human rights (Schabas, 2011) and thereby cut-down monitoring costs for the compliance with international law (Alter, 2004, Helfer/Slaughter, 2005) that were previously monitored by the ICJ or the Ad-hoc and hybrid criminal courts and tribunals. Democratic states can gain from this development since they often have a higher general interest in the improvement of international peace and security and they often are important financing states of international monitoring institutions. But also for autocratic states and, even more so, states that are transforming from autocracy to democracy, it would be a chance to increase the credibility of the states' commitments to (re-)build peace and security and deal with past atrocities (Moravcsik. 2000 Simmons, 2009). Therefore, the ICC is able to increase international and national security.

These strong opportunities might explain why most of the states have ratified the Rome Statute and are states parties to the ICC, among them even many non-democratic states, such as Afghanistan, Tunisia, Cambodia or the Republic of Congo. Nonetheless, there are several reasons to be cautious towards the ICC. Becoming a state party to the ICC brings with it some serious risks.

The ICC is the only international court in international relations that does not belong to an established international organization. Since it is an enforcement court and not 
an institution for mere dispute settlement or monitoring, it needs a strong executive power to enforce its rulings and decisions. Even though the Assembly of States Parties is the legislative power to the ICC and to some extent also takes over executive functions, the ICC is still missing clear institutional counterparts (Tomuschat, 2010). This leads to a certain instability in international relations and even more to a high uncertainty for the states assessing the consequences of becoming a state party to the ICC.

What if the ICC is too weak to withstand the manifold interests and preferences of political actors in international relations and becomes a gateway for politicization? There is a certain danger of a tactical misuse of the ICC's jurisdiction in order to get rid of political opponents. Many states choose a selective cooperation or noncooperation depending on their own political interests. Moreover, there is a certain danger of the UNSC (with 3 of 5 non-party states) becoming a gatekeeper of the ICC. What if the ICC becomes too strong, so that the principle of complementarity is eroded, and the states become in danger of losing more autonomy and self-determination that expected? The ICC can be considered as part of a larger growing judicialization (Stone Sweet, 1999, Shapiro/Stone Sweet, 2002) or even 'juristocracy' (Hirschl, 2004) in international relations.

In the context of transitional justice and international security [CT; and the ICC are decisive in shaping the agenda-setting of dealing with a violent past. Alternative instruments like reprieves and pardons or even amnesties lose their relevancy. Criminal courts play an important role in the development of international criminal law and in some way are even contributing to negative or positive lawmaking (Danner, 2006) and, sooner or later, the power of the ICC-Chief-Prosecutor has to be increased to balance the difficult position of the court in international relations.

The ratification of the Rome Statute is related to certain risks for the states, which raises concerns about unforeseen consequences in the long run. It might be true that 'hands-tying' by becoming a state party to the ICC enhances the credibility of commitments of (post-)conflict states willing to strengthen peace and democracy (Moravcsik. 2000 Simmons, 2009). This sends positive signals to domestic and international actors. At the same time, many states suffer from political instability and are in danger of becoming even more vulnerable by delegating sovereignty to the ICC when tying their own hands. In the worst case, they expose themselves to comparative disadvantages towards their political opponents that did not bind themselves to the ICC.

The situation is aggravated by the fact that the states know that each state must cope with those trade-offs. It is unclear how the other states will behave towards the ICC 


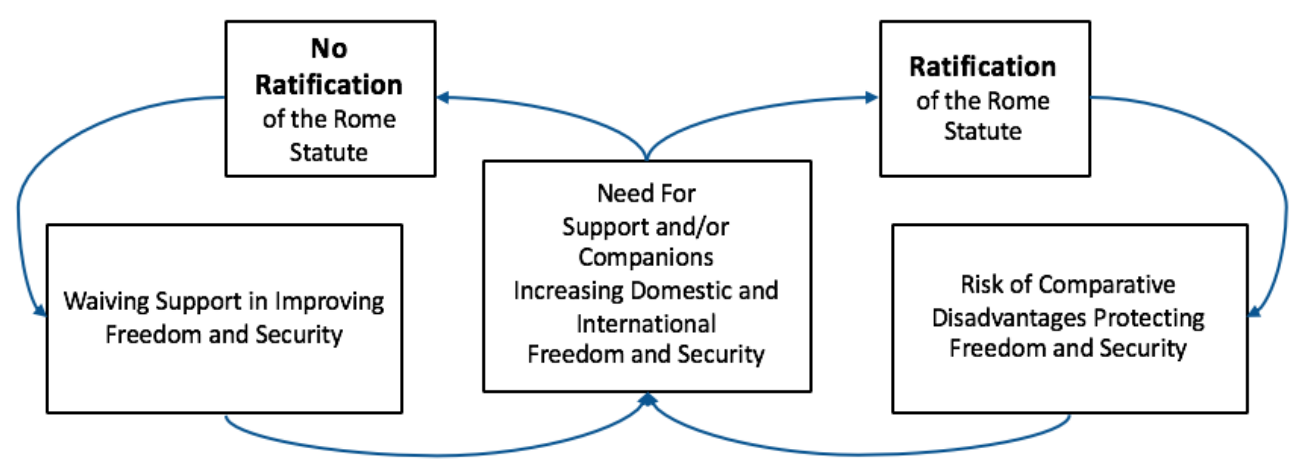

Figure 9: Delegation Dilemma of States towards the ICC

and how far the court is able to withstand the strategical and tactical behavior of the states. Thus, there is a certain mistrust of the other states as well as uncertainty towards the ICC itself. This might explain why some states did not ratify the Rome Statute or why many states at least selectively refuse to cooperate with the ICC.

As a result of the concurrency of strong opportunities and high risks, states get caught in the DELEGATION DILEMma TOWARDS THE ICC. Not ratifying would result in wavering of the privileges of being a state party and perhaps forfeiting support in dealing with the past, which is needed to strengthen freedom and security. However, ratification could mean a high risk of comparative disadvantages and a loss of room for strategical maneuver that is strongly needed to protect freedom and security and to fix the broken window of impunity. This is aggravated by the fact that the more the states need help and support of the ICC, the more they are exposed to the risk of making themselves vulnerable towards political opponents. In the end, it comes down to the classic balancing act between freedom and security.

\subsubsection{Constraining Courts Solving the Delegation Dilemma}

Solving the dilemma of delegating sovereignty to the ICC, states ratify the Rome Statute to become a state party to the ICC (improving their freedom and security), but constrain and customize their commitments to retain a certain room for political maneuver (protecting the own freedom and security). 
Although it would be very worthwhile to delegate sovereignty to an international institution increasing peace and security, the states have to maintain some extent of freedom to be able to protect themselves, since the ICC would not be able to comprehensively protect their security. We could say, since the benefits of delegating power to the ICC are limited, the states respond in kind by limiting their delegation, too.

From the cradle to the grave, states are involved in creating and running international courts. Often law and power are seen as two ends of a spectrum embodied in states and courts as antagonists in international relations. It is the states that decide about the creation of a court and its institutional design. It is the states that have to submit to the courts voluntarily and that decide about the national implementation. It is the states that finance the courts. It is the states that have to cooperate with the courts that carry out investigations and prosecutions. Finally, it is the states that decide how they handle the rulings of the court.

In several studies there can be found indication of the thesis that states constrain and customize their commitments to international courts and tribunals. Alter (2004, 38) argues that because of the fact that states cannot control the decision making of independent international courts they may use "tactics to avoid unwanted (...) rulings". Helfer/Slaughter (2005) who established the concept of "constrained independence" developed a model of how states limit the scope of action of international courts and tribunals. Correspondingly, states create independent international tribunals in order to solve international cooperation problems and to enhance the credibility of the states themselves. However, there is the danger of legal overstretching by the independent decision makers at those courts. Hence, states try to minimize their cost and to maximize their benefits by using mechanisms "to limit the potential for judicial excesses" (Helfer/Slaughter, 2005, 7).

"A tribunal that (...) [is] highly independent on the basis of its formal attributes may, in practice, be subject to political and discursive constraints that limit its potential for overreaching". (Helfer/Slaughter, 2005, 32)

They rely on the concept of 'strategic space' of Steinberg (2004). He shows in the example of the WTO Dispute Settlement Body that lawmaking is only possibly within certain discursive, constitutional and political constraints.79

According to Helfer/Slaughter (2005), on the one hand, there are states constraining international courts and tribunals via political and structural mechanisms and, on the other hand, there is the global community constraining international courts and

${ }^{79}$ Further studies on political constraints of international legal institutions are e.g. Alter (2000); Carruba et al. (2008); Carruba (2012). 
tribunals via discursive mechanisms. The mechanisms for state regulation can be distinguished between ex-ante and ex-post-mechanisms. Structural mechanisms ex ante are e.g. reservations to substantive rules or rules to regulate access and procedure. Structural mechanisms ex post are e.g. reinterpretation of substantive rules or the delay in implementing a decision. Political mechanisms ex ante are e.g. inadequate funding or resources and political mechanisms ex post are e.g. non-compliance or forum shopping. Discursive mechanisms are e.g. interpretative methodologies (Helfer/Slaughter, 2005. 46ff.).

In a similar manner, Simmons (2009, 89) takes into account that states are able to 'customize' their commitments by making reservations and interpretative declarations and argues: "Treaty ratification is not the end of the commitment story. Governments have options to "customize' their commitments through the use of reservations and declarations".

Systematizing those arguments, we can distinguish between collective constraints of international courts. States limit the scope of action for the respective court as a whole and they make individual constraints of commitments to international courts by limiting their own individual degree of binding to the respective court. There are at least the following COLLECTIVE CONSTRAINTS ON THE INDEPENDENCE OF AN INTERNATIONAL COURT:

- creating an international court

- influencing the institutional design

- cooperating with the court

- supporting the court on the political level

From the first beginning, states are involved in writing and negotiating the institutional design of the court (Koremenos, 2007). Although this process takes a lot of time, as in the case of the ICC, which was first discussed after World War II, one can retrace the institutional imprints of single powerful states (Katzenstein, 2014). A prominent example for this is the USA, which advocated e.g. for the principle of complementarity or the checks and balances of the Prosecutor's power (Brown, 1999, 861) and later withdrew their signature of the Rome Statute, as they did not succeed in making the role of the UNSC more powerful within the ICC-regime (Schabas, 2004) 80

${ }^{80}$ John Boltan, a conservative republican and former US-American embassy at the UNO putted in a nutshell saying: "[N]ever before has the United States been asked to place [the power of law enforcement] outside the complete control of our government without our consent", quoted from (Schabas 2004, 719). 
Once an institutional design is negotiated and founding treaties are adopted, states have to submit to the courts voluntarily and can decide on the national implementation of the respective legal norms. It is the states that finance the courts and, finally, it is the states that have to cooperate with the courts, so that those are able to carry out investigations and prosecutions.

How do states react towards independent international courts? States are used to choose international agreements selectively and customize their commitment to international law. Although international courts and tribunals need the assistance of expert and advocacy networks, too - maybe even more than ever - it is the states that decide on the creation of a court. If we compare successful and failed trials of establishing a court, we can see that the success or failure is often dependent on the existence of a crisis and the action of hegemonic states in overcoming the crisis (Katzenstein, 2014).

\footnotetext{
" Crises unsettle the international legal order. Eager to restore it, governments become more willing to cooperate with one another and to overcome their prior reluctance about creating an international court. Crises also provide new opportunities for legal networks to advocate for the creation of international courts." (Katzenstein, 2014 151)
}

As mentioned above, states create courts because they need them for solving problems. But as they are the creators of the courts, they decide about their shape. In the case of the ICC, we could ask why the creation of the court was successful in 1998, although the USA was strongly opposed to the court. Helfer/Slaughter (2005) consider certain possibilities of designing international courts and tribunals to constrain their independence. In the following, the institutional design of the ICC emphasizes the possibilities for states to use the flexibility of customizing commitment for their own benefit.

When establishing an international ad-hoc or permanent tribunal according to (Aksar 2005 18) there are four conceivably possible ways: a) concluding an international agreement, b) adopting a resolution in the General Assembly of the UN, c) adopting a resolution in the Security Council of the UN under Chapter VII ("Action with Respect to Threats to the Peace, Breaches of the Peace, and acts of Aggression") or d) amending the UN Charter.

While the ad-hoc tribunals [CTY and [CTR were created through resolutions of the Security Council of the UN 81 the ICC was established by means of an international agreement, namely the Rome Statute of the ICC. A treaty-based establishment has the advantage that states can exercise their sovereign will in the negotiation and the

81 The ICTY was established by UN Security Council Resolution 827 of May 1993 and the ICTR by Security Council Resolution 955 of November 1994. 
conclusion of the agreement. Moreover, the sovereignty of states is taken into account by the fact that the court or tribunal has only jurisdiction over states that willingly became party to the statute.

In the case of the Rome Statute, we can see that the USA were quite involved in the development process. Hence, the institutional design is markedly shaped by the USA.

"The U.S. imprint is, in fact, all over the statute: in ensuring due process in trials, in the priority given to national courts, in the checks and balances on the powers of the prosecutor. These are some of the remarkable achievements of the U.S. delegation to Rome, ably lead by Ambassador David Scheffer." (Brown 1999, 861)

"While awaiting instructions on sensitive political issues such as the jurisdictional regime, U.S. delegates in Rome nonetheless worked tireless on the technical details of the Statute. These delegates, especially those from the Justice Department, identified and helped find solutions for a number of problems in the text of the draft ICC Statute. As a result of their efforts, and the consensus they built with delegates from other States sharing the same fundamental values and perspectives, the Rome Statute bears the strong imprint of the U.S. legal system." (Brown, 1999, 861)

Besides those collective constraints on international courts, every state has the possibility of constraining or customize its formal commitment to an international court with regard to e.g. making reservations or interpretative declarations or the non-ratification of additional and amending agreements. As the present work is driven by the question as to why states behave contradictorily towards the ICC, the focus will be on the individual constraints of commitments aimed at retaining room for political maneuver.

\subsubsection{States Customizing and Constraining their Commitments}

As shown above, the trade-off between freedom and security on the domestic and the international level can grow into a dilemma, which states try to solve by constraining and customizing their commitment to the ICC. From contract theory we know that each party to a contract wants the others to commit, while preserving flexibility, leaving room for maneuver for itself to cope with unforeseen consequences. This creates an irreducible tension between two objectives:

"In order to motivate (and protect) investments in the cooperative enterprise, each investing party would like to ensure the commitment of the others. But subsequent events may render inflexible commitments inconsistent with the contractual objective maximizing the joint surplus." (Scott, 2003, 61)

Each contract is a promise for a certain future behavior, although the future is unknown. Thus, every commitment to a contract entails risks, since the consequences 
might be much more costly than expected. One conceivable solution would be to wait until the parties know more about the future and the acquired benefits of entering into the contract. However, a promise that is without costs would lose its value (Scott), $2003,63 f f$.$) .$

Transferring this to the ICC we can say that states want the others to bind themselves honestly and completely to the Rome Statute, while retaining their flexibility and independent, since it is unclear what the consequences of tying their own hands could be. Claude Jorda, former judge and president of the [CTY said as early as 2004:

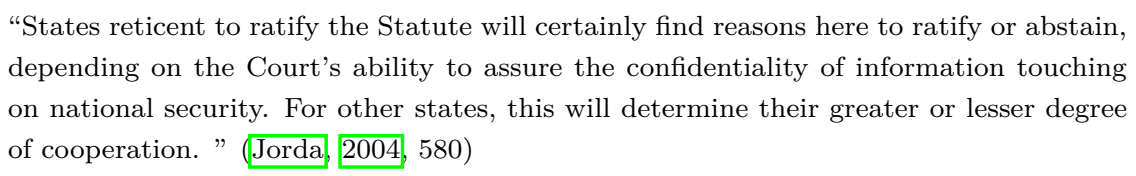

Further he predicted:

"But, a close reading of the Statute and the Rules of Procedure indicates the extent to which the States Parties - in the end, many fewer than there are signatories - wished to protect themselves from any unpleasant surprises, not to mention the avoidance schemes of certain states not party to the Treaty." (Jorda, 2004, 584)

The states use all possible means at their disposal to constrain and customize their commitments to solve the delegation dilemma to the ICC. In doing so they are able to ratify the Rome Statute and become a state party to the ICC and still retain room for political maneuver.

An actor-centered perspective on the states will be chosen for the present work in order to analyze political constraints of the ICC and to measure variation in states behavior. This includes but is not limited to the following INDIVIDUAL CONSTRAINTS OF STATES' COMMITMENTS TO INTERNATIONAL COURTS:

- becoming a state party

- making declarations and reservations

- joining additional and amending agreements

- implementing into national law

- complying to the guarded norms

- triggering investigations 
We can expect the states to vary strongly in their behavior on the DIMENSIONS OF commitment to the ICC. Although states ratify the Rome Statute (Dim1), they can make (interpretative) declarations regarding certain articles of the Rome Statute (Dim2), they can refuse to ratify additional or amending agreements, such as the Agreement on the Privileges and Immunities of the ICC (APIC) or the amendment to the crime of aggression (Dim3). They can delay the implementation of legislation on complementarity or cooperation (Dim4) and they can refrain from triggering investigations and prosecutions (Dim5) ${ }^{82}$

As a matter of course, the degree of formal commitment to the ICC does not necessarily tell something about the actual compliance behavior of the state, be it future violations of the core crimes or the state's willingness to cooperate with the ICC. Both the states' real interest in binding themselves to the Rome Statute as well as the mere 'window dressing' are able to coexist with one another and are not necessarily contradictory. There are several further possibilities of influencing the work of the ICC and to support or undermine the ICC, such as delaying support or selective non-cooperation (Wartanian, 2005, Hillebrecht/Straus, 2017), refusal to pay fees (Romano, 1998) or political undermining, such as the negotiation of bilateral non-surrender agreements (Kelley, 2007).

In a political view, we can understand the different levels of formal commitment to the ICC as an attempt to retain room to maneuver that is available for all states, whether this will be factually needed or not, since there is reason to retain a certain room for maneuver for most of the states, be they democracies or non-democracies 83

The most visible and still most important act of commitment to a court is JOINING THE FOUNDING TREATY and becoming a state party to the international court. In accordance with the $\overline{\mathrm{VCLT}}$ which rules the law of treaties between states, there are several possibilities of expressing consent to be bound by a treaty:

\footnotetext{
"The consent of a State to be bound by a treaty may be expressed by signature, exchange of instruments constituting a treaty, ratification, acceptance, approval or accession, or by any other means if so agreed." (art.11 VCLT)
}

In the political science literature on international law, those acts of self-binding are referred to as commitment to international law, which is often researched in relation to

\footnotetext{
82 According to the model of Helfer/Slaughter 2005 the individual constraints on the commitment of the state would be appropriate to the formal/structural mechanisms ex ante (ratification of Rome Statute and the amending agreements, declarations and reservations) and ex post (triggering jurisdiction).

${ }^{83}$ In order to improve readability henceforth the 'level of formal commitment' will be termed as 'level of commitment'.
} 
compliance with the law compliance with the law (Simmons, 2009; Shelton, 2000, Risse et al. 2013). The phenomenon that states often do not comply with the norms they voluntarily bind themselves to, if often designated as a "gap between commitment and compliance" (Simmons, 2009), as a form of window dressing (Hafner-Burton/Tsutsui, 2005 in that the states adorn themselves with the borrowed plumes of human rights without the real intend to follow through.

The underlying puzzle of the present work outlined at the beginning shows for the case of the ICC, as in many other law regimes, this problem is persistent, too, despite the existence of a court. Therefore, the concept of commitment to international law that is monitored or even enforced by a court has to be broadened by the following aspects. A further important aspect of commitment to the law of a court is the consent to be bound by the ADditional and amending agreEments. According to the VCLT "[a] treaty may be amended by agreement between the parties" (art.39 VCLT). Such amendments must be effected with the same formalities applied to the original formation of the treaty. Every state party to the treaties being amended has the entitlement to be party by the amendment and every state that does not accept the amendment is not bound to it (art. 40 VCLT).

This means, the states parties of an international agreement are possibly not all bound to the same scope of norms. However, controversial norms can be often found in amendments rather than in the constitutional treaty itself 84

There is the possibility of MODIFYING THROUGH MAKING RESERVATIONS AND INTERPRETATIVE DECLARATIONS 85

According to the $\mathbb{V C L T}$ it is possible to express reservations to an international agreement, i.e. "a unilateral statement, however, phrased or named, made by a state, when signing, ratifying, accepting, approving or acceding to a treaty, whereby it purports

\footnotetext{
$\overline{84}$ An example for this are the Protocols I and II Additional to the Geneva Conventions of 12 August 1949 that added rules on permitted methods and means in warfare and on protection of human rights in international and non-international armed conflicts. There are only 41 of 195 states that have bound themselves both to the Geneva Convention and all its additional protocols. The USA for example ratified only the Geneva Conventions I-IV and the Additional Protocol III on the "Adoption of an Additional Distinctive Emblem", but not AP I on the "Protection of Victims of International Armed Conflicts" or APII on the "Protection of Victims of Non-International Armed Conflicts", what could be considered as reason for a legality of the detention camps in Guantanamo Bay. For a discussion on this see the debate between (Vöneky et al. 2004 Bellinger 2006 Vöneky 2007 Bellinger/Padmanabhan, 2011).

85 Definitions and rules of the use of reservations are laid down in the vienna Convention on the Law of Treaties 1969 (VCLT) and the "Guide to Practice on Reservations to Treaties" of the International Law Commission from 1993. The Guide to Practice on Reservations to Treaties from the ICC was initiated in 1993 to fill the gaps and lacks of the VCLT, for detailed explanations see Fitzmaurice (2006).
} 
to exclude or to modify the legal effect of certain provisions of the treaty in their application to that state" (art.2(1)(d) VCLT) 86

Simmons (2009, 98) states that "[t]he nature of reservations they [i.e. states] make can have significant impact on the precise nature of the legal obligation each government commits to undertake" 87 States try to exclude themselves from certain legal effects of the agreements. Especially in human rights treaties it is a widespread practice to make reservations. Human rights treaties can be considered a global public good that impose duties on states without granting direct expressed benefits.

Reservations have to be distinguished from mere political statements, so called interpretative declarations that are defined as "unilateral statement $[\mathrm{s}]$, however phrased or named, made by a State or an international organization, whereby that State or that organization purports to specify or clarify the meaning or scope of a treaty or of certain of its provisions" (International Law Commission, 2011). A declaration can be considered as a reservation, too, if the state party thereby recognizably wants to be bound only in the sense of the stated declarations. Often it is very difficult to distinguish clearly between mere interpretative declarations and conditional interpretative declaration (Herdegen, 2013).

Reservations to multilateral agreements cause two major problems: there is a need to clarify the permissibility of a reservation regarding the pursued limitation of obligation and, moreover, there is a need to clarify the legal consequences if some states accept the reservation and others do not. The effects of an indispensable reservation are disputed. The UN Human Rights Committee and the ECHR are of the opinion that inadmissible reservations to human rights treaties mean that the state concerned is basically bound to the full extent. The USA, Great Britain and France criticized this harshly, arguing that full contractual obligation would not be covered by the reserving state any longer (Herdegen, 2013, 127f.).

$\overline{86}$ Reservations can be differentiated in reservations ratione materiae, ratione temporis and ratione loci. Contend-related reservations shall diminish the legal obligation or exclude the State from legal obligation. Time-related reservations shall limit the obligation temporarily and thereby cutting past events. Territorial reservations shall exclude certain territories from application of the human rights treaty (Giegerich 1995, 718ff.).

87 However, the possibility making reservations is limited by the fact that all other state parties have to agree to them the special conditions. According to the International Law Commission $(2011,235)$ objection "means a unilateral statement, however, phrased or named, made by a State or an international organization in response to a reservation formulated by another State or international organization, whereby the former State or organization purports to preclude the reservation from having its intended effects or otherwise opposes the reservation". 
States that make reservations, declarations and objections to human rights treaties shows very well the dilemma in which states find themselves in relationship to international courts. This argument is even to be found in the legal literature:

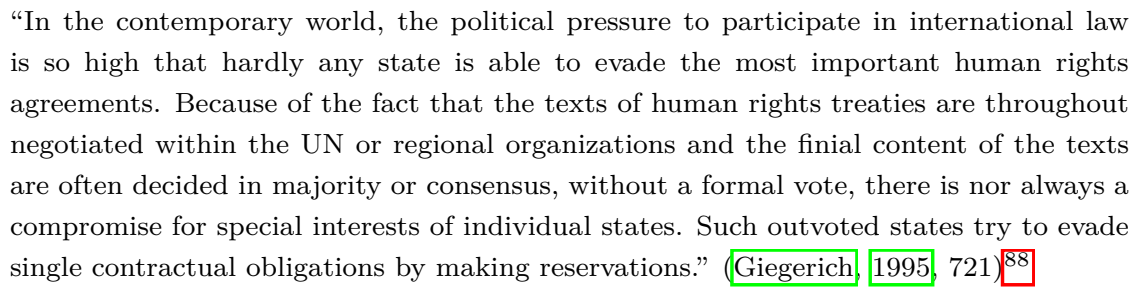

Furthermore, the IMPLEMENTATION OF NORMS OF INTERNATIONAL AGREEMENTS INTO NATIONAL LAW can be considered as an important success and as a fundamental aspect of committing to the agreements concerned. The implementation of international agreements into national law opens the technical way of applying and adjudicating in national courts and increases the political legitimization of the norms in domestic affairs. There is a qualitative difference between the necessity of implementation due to the legal system. States with a civil law system tend to be monistic. States with common law systems tend to be dualistic. The latter often need the act of implementation into national law to ensure the binding force of international law, while the former do not need implementation. Nevertheless, or even because of this, an act of implementation, especially in states with a civil law system, can be considered as an important aspect of commitment to an international court.

BRINGING CASES TO A COURT OR TRIGGERING INVESTIGATIONS ACTIVELY is a further strong indicator of commitment to a court. At international courts and tribunals there is often no compulsory investigations or even prosecutions, since it is a principal idea that they are - due to their institutional design - mere dispute settlement mechanisms or institutions of last resort. One the one hand, this is due to the limitations of material and personal resources of international judicial institutions. On the other hand, we can expect states that bring their cases proactively to an international court to be more willed to accept the decisions and rulings of a court. Thus, the court can reach a higher political legitimization and higher chances for success.

Accordingly, COMPREhensive COMmitments to the ICC can be defined as acts of states expressing approval and support for the International Criminal Court. This includes but is not limited to the ratification of the corresponding agreements on ma-

88 Own translation. 
terial and procedural norms without reservations, the implementation of these norms into national law and the proactive initiation of investigations and prosecutions.

Constraining and customizing those commitments means limiting or shaping such a comprehensive commitment. According to the DELEGATIOn DiLEMma of the states, we can expect those states that in principal need the ICC the most since they suffered from a violent history and want to deal with the past, (re-)build peace and democracy, and thus improve their freedom and security, to constrain and customize their commitments the most, since they also have the greatest cause for concern from negative consequences and thus have to protect their freedom and sovereignty. We can expect that among the non-party states, there will be mainly a very low level of commitment to the ICC. However, even among the parties, there will be only a few states with a high level of commitment, while most of them will have strongly constrained and customized commitments. 


\subsection{Solving Cooperation Problems with the ICC}

\subsubsection{Cooperation Problems of International Law}

The yet open question is: What explains the extent to which states constrain and customize their commitment to the ICC? Which states will bind themselves comprehensively to the ICC and which will protect themselves vigorously.

Although there are undoubtedly both strong opportunities and high risks in ratifying the Rome Statute and becoming a state party to the ICC, those will not lead to benefits and costs for every kind of state to the same extent. Self-binding to the ICC can be hazardous for states. In principal, we can expect those states need the ICC the most that have the highest incentives to protect themselves against possible attacks of their political opponents.

Sikkink (2011) with her concept of the 'justice cascade' holds the view that the universal norm of criminal accountability spread around the globe in a cascade from Nuremberg and Tokyo trials over some of the core treaties of humanitarian law and human rights, such as Genocide Convention, Geneva Conventions or Convention against Torture up to the establishment of the ICC. Conversely, it can be argued that the states behavior towards the ICC is connected with their position towards humanitarian law and human rights.

The basic assumption behind is that the ICC presents a strong opportunity to solve cooperation problems of international law. As shown in the subsection on states' commitment to international law ${ }^{89}$ under the conditions of anarchy in international relations, states suffer from a lack of cooperation, since there is mistrust and uncertainty between the states and they are caught in prisoner's dilemma (Axelrod, 1980 Keohane, 1984a).

Concluding international agreements is one possible solution of the dilemma, since it reduces negotiation costs and creates legitimacy (Abbott, 1989) in addition to reducing uncertainty on the behavior of the other and creating predictability in the shadow of the future (Keohane, 1984a). In an ideal situation "the law itself must be an equilibrium in an non-cooperative game" (Koremenos, 2007, 191) and thus becomes self-enforcing over the mechanisms of reciprocity (Keohane, 1984a) or retaliation (Mearsheimer, 1995), reputation (Guzman, 2008a), persuasion (Hawkins, 2004, Deitelhoff, 2009) or socialization (Koh, 1997, Goodman/Jinks, 2013).

In the case of humanitarian law the mechanisms of retaliation or reciprocity can work (Watts, 2009). However, in the case of human rights there are hardly any self-enforcing

89 See Commitment to International Law p. 30 
mechanisms, since their violations mostly occur within states and not among states (Tomuschat, 2014). It can be argued that compliance with international law is worst, if there are neither or hardly any options of sanctioning nor self-enforcing mechanisms (Scott, 2003), such as in the case of human rights.

Thus, under the conditions of international law, there is an enforcement problem as the states often commit to human rights but afterwards do not comply with them (Hathaway, 2002). The human rights performance of autocracies sometimes becomes even worse after ratifying (Hafner-Burton/Tsutsui, 2005) and a huge gap between commitment and compliance remains (Simmons, 2009). This means that there are appropriate norms and respective treaties that often even have good rates of ratification. States cannot be sure if other states comply with humanitarian law and especially human rights. If they want to make sure which states comply, they must invest in monitoring mechanisms for observation of human rights practices.

There is a reputation problem, since it is unclear, which commitments lead to compliance (Moravcsik 2000). If states do have a good compliance behavior, they have to find ways signaling this to other states, since the ratification alone is no warranty for a good compliance. Confronted with the reasons for being cautious towards the ICC such as being too weak or becoming too strong the states are caught in a prisoner's dilemma and have a high uncertainty as to the behavior of the others. Therefore, states that have an interest in the compliance and need information on cases of non-compliance have high costs for monitoring humanitarian law and human rights.

Creating international courts and tribunals such as the ICC with the task of enforcing humanitarian law and human rights and delegating authority to them is thus an important opportunity for the states to solve those cooperation problems, reduce costs of monitoring and enhance credibility of commitments. However, we cannot expect the possibility of solving cooperation problems to be the same for all states. Dependent on their political interests and preferences, different incentive structures arise for the states. Although enhancing monitoring and credibility are plausible ways to solve cooperation problems according to the group rationality of the community of states, they do not inevitably lead to advantages for every single state in its individual rationality. In light of these considerations, the central thesis of the study is: The extent of commitment to the ICC depends on both the states' interests in governing the international community and the states' general attitude towards humanitarian law and human rights. 
Law Solving Cooperation Problems

of International Anarchy

Negotiating International Agreements

$\rightarrow$ Reducing Negotiation Costs and Uncertainty

$\rightarrow$ Creating Legitimacy and Predictability

$\rightarrow$ Promoting Cooperation
Courts Solving Cooperation Problems

of International Law

Establishing International Courts

$\rightarrow$ Reducing Costs of Monitoring

$\rightarrow$ Enhancing Credibility of Commitments

$\rightarrow$ Promoting Cooperation
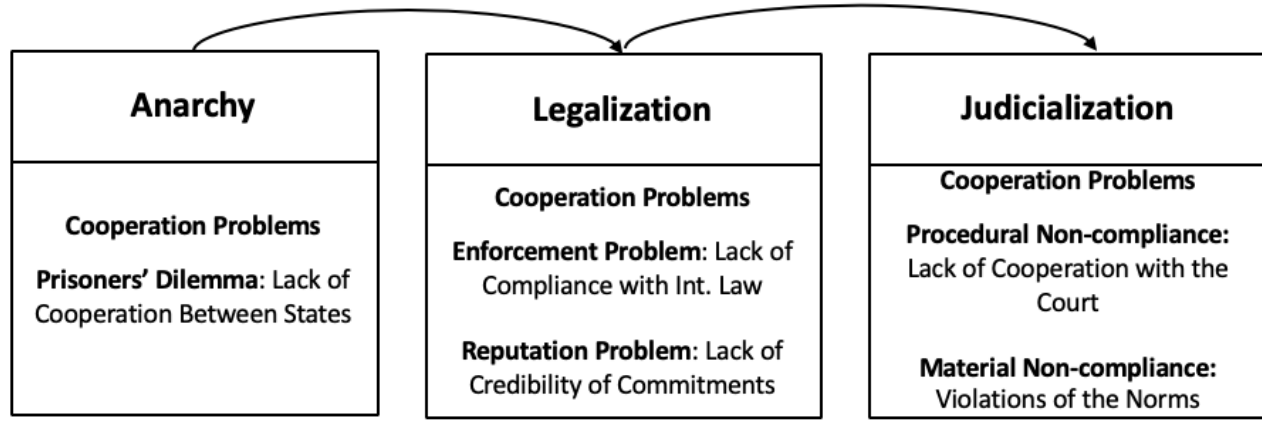

Figure 10: Solving Cooperation Problems with the ICC

\subsubsection{Reducing Costs of Monitoring versus Fear of Monitoring}

The first decisive factor for the states behavior towards the ICC is the states' interest in governing the international community. As mentioned above, the ICC provides a window of opportunity to integrate several mechanisms in international relations which enables the monitoring of compliance with humanitarian law and human rights law. This raises the possibility that at some point in the future the groundwork will have been laid to establish one permanent international court. This court is not only able to monitor, but even creates criminal responsibility and thus makes it possible to investigate and prosecute individual perpetrators immediately.

The following question arises as to which states benefit the most from the enforcement of international criminal law through the ICC? We can expect those states to take full advantage of the ICC that were politically and financially highly engaged in the creation and running of the several mechanisms to monitor humanitarian law and human rights be they on the international, regional or national level. For those states, the establishment and the success of the ICC results in a considerable reduction of monitoring costs. Despite the lack of a mandate to monitor the compliance of severe human rights violations the highly centralized institutions indirectly undertakes the 
tasks of monitoring thereby reducing costs for the states. An additional benefit is that the ICC then provides a devices to label violations and to name perpetrators.

This is especially true for states that have a high level of political freedom and that recognized the 【CJ for compulsory jurisdiction and states with a high level of political freedom have a high interest in governing the international community and in increasing international peace and security.

For one thing, this is based on the Kantian thesis of democratic peace, that says that states with a high level of democracy are more peaceful and more interested in international law. Democracies have domestic institutions that make it possible to find peaceful conflict solutions. Democracies are inter alia characterized by a strong rule of law. The stronger the rule of law, the more likely it is that states support legalization of international politics. Immanuel Kant described in his famous work 'Perpetual Peace' individuals as self-interested actors driven by reason, living in a state of nature independent of external laws, striving for security by adopting laws (Vorländer/Kant, $1795 / 1973,130 f$.$) .$

To reach global peace, all people have to belong to any civil constitution and three areas of law have to exist: citizen rights (ius civitas), international law of the nations (ius gentium) and cosmopolitan law (ius cosmopoliticum): Firstly, in every state the form of governing should be republican. Kant considers representation and the separation of powers as essential. He points out that legislative power and executive power must not be united in the same person or institution 90

Secondly, international law should be based on federalism of free states. They, however, differ insofar from individuals in a state of nature as they have a domestic constitution that constrains their behavior. Nevertheless, those free states are able to enter into contract with each other by establishing a confederation or a league of states, rather than a federation of a world state. The problem arises that in every state the government is a superior power in relation to the people as an inferior power. He emphasizes that the only way for states to get rid of the hostile state of nature is to give up autonomy and enter into an international public law. Thirdly, the law of world citizenship should be limited to universal hospitality. This means that everyone should have a right to visit the others under peaceable conditions (Vorländer/Kant, $1795 / 1973,117-169)$.

\footnotetext{
90 Interestingly, Kant uses this assumption to argue that a democracy actually is a form of despotism because everyone claims to be the master and thus there is no representation, see Vorländer/Kant (1795/1973, 129f.).
} 
In a Kantian world, ensuring compliance with international law is very expensive. States comply particularly if they are liberal republican states and the others are, too. States that are not liberal have to be monitored closely to ensure their compliance.

"[It] is often difficult for a state to monitor the conduct of its treaty partners and to evaluate whether that conduct violates the treaty. These monitoring and evaluation costs reduce the risk that arguable nonconforming conduct will be detected or, if detected, will be accurately labeled as a breach. International tribunals reduce these monitoring and evaluation costs. The create a mandatory process by which plausible rule violations are investigated and, at the conclusion of the case, they publicly identify the probability that violations of international obligations will be detected and correctly labeled as non-compliance." (Helfer/Slaughter, 2005, 36)

It is to be assumed that the higher the level of political freedom of the citizens on the domestic level, the higher the interest of political freedom of the states on the international level. Democracy at the domestic level corresponds in some way to a 'polycracy' of the states at the international level, meaning that not only the citizens of a state shall have the same rights and duties, but also the different states at the international level.

\section{Hypothesis 1: The higher the level of democracy, the higher the level of} commitment to the ICC.

Additionally, states with a high level of political freedom are often closely involved in the running and financing of international and regional organizations. Those organizations in turn are composed of mainly democracies and often have mechanisms of monitoring the compliance with humanitarian law and human rights. Beyond a high level of political freedom, we can expect those states that have recognized the IC.] for compulsory jurisdiction benefit strongly from an enforcement of international criminal law through the ICC. According to article 36 of the ICJ Statute, states parties to the court:

\footnotetext{
"may at any time declare that they recognize as compulsory ipso facto and without special agreement, in relation to any other state accepting the same obligation, the jurisdiction of the Court in all legal disputes concerning: a. the interpretation of a treaty; b. any question of international law; c. the existence of any fact which, if established, would constitute a breach of an international obligation; d. the nature or extent of the reparation to be made for the breach of an international obligation."
}

For the states that recognized compulsory jurisdiction, this means that they can bring any issue of international law to the court. This means that the [C] has to decide on manifold different areas of international law. The establishment of the ICC with 
its narrow jurisdiction has created a specialized permanent court with its privileges individuals. This promises to increase considerably the efficiency of the enforcement of humanitarian law and human rights. Correspondingly, the second hypothesis is:

Hypothesis 2: States that have acknowledged the ICJ for compulsory jurisdiction tend to have a higher level of commitment to the ICC.

It can be concluded that up until the creation of the ICC the monitoring of humanitarian law was unclear, politically complex, expensive, and most of all, unreliable. The establishment of the ICC can be considered a window of opportunity to improve international monitoring of humanitarian law and human rights as a permanent international court through enforcement of international criminal law. Those states benefit the most from this that have a high level of political freedom and perhaps have recognized the [C.] for compulsory jurisdiction. Those are already highly involved in the running and financing of several international monitoring mechanisms. For them, the ICC brings with it a considerable reduction in monitoring costs. It offers these state parties an opportunity to consolidate their investment in several international monitoring mechanism into one.

\subsubsection{Enhancing Credibility versus Window Dressing}

The second decisive factor for the states' level of commitment to the ICC is the states' fundamental interest in governing the international community. Beyond the reduction of costs for monitoring humanitarian law and human rights, a comprehensive support of the ICC offers a chance for the states to make the commitments they have made to humanitarian law and human rights more credible. As stated above, a public tying of the own hands can increase the credibility of states considerably.

The question arises: which states benefit the most by enhancing the credibility of commitment to humanitarian law and human rights? Firstly, states that need this credibility the most are new democracies, as Moravcsik (2000) and Simmons (2009) argue. It offers a chance to signal to domestic and foreign actors that they are seriously willing to cope with the past and promote the development of democracy.

Secondly, it is the states that have a high level of commitment to humanitarian law and human rights, since these can be considered to be an indicator of the general attitude towards international legalization in the area of peace and security. Moreover, those states that have ratified only a few of the respective international agreements would be subjected to a higher risk of unintended consequences than states that are bound tightly to humanitarian law and human rights. 
Hypothesis 3: The higher the level of commitment to human rights, the higher the level of commitment to the ICC.

Hypothesis 4: The higher the level of commitment to humanitarian law, the higher the level of commitment to the ICC.

This is based on the fact that international law is pluralistic (Berman, 2007), highly fragmented (Fischer-Lescano/Teubner, 2007) and states can often decide on a case-bycase basis, which agreements they ratify.

The complex of humanitarian law consists of at least 25 treaties. The most important among them are the four Geneva Conventions - on the protection wounded and sick in the field (GCI) and at sea (GCII), of prisoners of war (GCIII) and of civilian persons (GCIV) in times of international and non-international armed conflicts - as well as the three additional protocols relating to the protection of victims of international (PI) and non-international (PII) armed conflicts and distinctive emblems (PIII). Moreover, there are treaties on the protection of culture and environment in armed conflicts and the numerous treaties on the use of weapons in armed conflict, e.g. the "Convention on the Prohibition of the Development, Production, Stockpiling and Use of Chemical Weapons and on their Destruction" of 1993 or the "Convention on Cluster Munitions of 2008"; as well as the "Convention on the Prevention and Punishment of the Crime of Genocide" (1948) or the "Convention on the Non-Applicability of Statutory Limitations to War Crimes and Crimes against Humanity" of 1968.91

In the legal area of human rights meanwhile over 20 agreements and additional protocols on human right law were concluded. The Office of the United Nations High Commissioner for Human Rights (OHCHR) collects the data on ratification of the 18 most important agreements ${ }^{22}$

Among them are the aspects mentioned in the Rome Statute concerning severe violations of human rights, such as the "Convention against Torture and Other Cruel, Inhuman or Degrading Treatment or Punishment" of 1984 or the "International Convention for the Protection of All Persons from Enforced Disappearance" of 2006. However, states that have a low level of commitment to human rights and humanitarian law are not persuasive in enhancing credibility and rather use the commitment to the ICC as window dressing. In that regard, Moyn (2014 84) raises the question:

"[W]hy persist in upholding the fiction that human rights name an inviolable consensus everyone shares? Like all universalist projects, human rights are violated every time

91 A full list of the 25 counted treaties of humanitarian law is to find in the annex on p. 239

92 A full list of the 18 counted treaties of human rights law is to find in the annex on p. 240 
they are interpreted and transformed into a specific program. Because they promise everything to everyone, they can end up meaning anything to anyone."

We can measure the scope of commitment to humanitarian law and human rights in respect of the number of treaties ratified and the depth of commitment in respect to the lack of reservations to the treaties. Up to date of measurement, only Uruguay has ratified all 43 agreements (including their additional and optional protocols) of human rights and humanitarian law. In second place are Argentina and Costa Rica with 42 ratified treaties, in third place Slovakia, Spain and Italy with 41 treaties and in the forth place Albania, Belgium, Germany and Finland with 40 ratified treaties.

As we know that ratifying human rights treaties is no guarantee for compliance, we have to put the information value of such counts into perspective. But even at states with high levels of commitment to humanitarian law and human rights it is worth looking at which treaties are not ratified.

Germany for example did not ratify the "Convention on the Non-Applicability of Statutory Limitations to War Crimes and Crimes against Humanity from 1968", the "International Convention on the Protection of the Rights of All Migrant Workers and Members of their Families from 1990" and the "Optional Protocol to the International Covenant on Economic, Social and Cultural Rights from 2013".

Belgium did not ratify the "Convention on the Non-Applicability of Statutory Limitations to War Crimes and Crimes against Humanity from 1968", the "Optional Protocol to the Convention against Torture and Other Cruel, Inhuman or Degrading Treatment or Punishment from 2006" and the "International Convention on the Protection of the Rights of All Migrant Workers and Members of their Families from 1990".

The universality of human rights along with the absence of enforcement mechanisms leads to the fact that particularly autocratic states do not take their commitment very serious. However, establishing an international court such as the ICC increases the probability of consequences of norm violations considerably. Thus, particularly for states with a low level of commitment to humanitarian law and human rights, the ICC poses a high risk.

There are democracies that have a very high level of commitment to humanitarian law and human rights and there are others whose commitment is very low. Democracies that ratified all 25 treaties of humanitarian law ${ }^{93}$ are Slovenia, Hungary, Czech Republic, Slovakia, Bulgaria, Uruguay, Costa Rica and Panama. Those that ratified 24 treaties are Finland, Belgium, Netherlands, Germany, Austria, Switzerland, Spain,

93 As of 2016. 


\begin{tabular}{cccc}
\hline & & NON-DEMOCRACIES & DEMOCRACIES \\
\hline \hline Min & 3 & 0 & 2 \\
& 4 & 3 & 2 \\
\hline \multirow{3}{*}{$\operatorname{Max}$} & 24 & 1 & 14 \\
\hline
\end{tabular}

Table 3: Minimum and Maximum Scores - Ratification of Humanitarian Law

\begin{tabular}{cccc}
\hline & & NON-DEMOCRACIES & DEMOCRACIES \\
\hline \hline Min & 2 & 0 & 1 \\
& 3 & 0 & 4 \\
\hline \multirow{3}{*}{ Max } & 17 & 3 & 6 \\
\hline
\end{tabular}

Table 4: Minimum and Maximum Scores - Ratification of Human Rights Law

Italy, Poland, Lithuania, Romania, Croatia, New Zealand and Argentina. Excluding small city and island states, the democracies with the lowest number of ratified HL treaties are Suriname (7), Namibia (7), Botswana (8), Belize (10), Israel (11), South Korea (14), Ghana (14), Benin (14), Senegal (16) and the USA (16).

Democracies that ratified all 18 treaties of human rights are Uruguay and Argentina. Those that ratified 17 human rights treaties are Mongolia, France, Portugal, Costa Rica, Spain and Italy. Excluding small city and island states, democracies with the lowest number of ratified human rights treaties are Suriname (7), Botswana (8), India (8) and Israel (9).

The non-democracies that unexpectedly ratified a very high number of humanitarian law treaties include the following: Paraguay (24), Macedonia (23), Guatemala (23), Nicaragua (22), Bosnia and Herzegovina (22), Montenegro (22), Moldova (22) and Albania (22). Non-democracies that ratified a very high number of human rights treaties include: Bolivia (18), Albania (18), Bosnia and Herzegovina (17), Ecuador (17) and Montenegro (17).

Thus, whether a state is a democracy or not is not a sufficient condition for commitment to humanitarian law and human rights and, respectively, to the ICC. The general attitude to international law and international integration in general plays an important role, too.

The ICC provides a chance for all states to make themselves more attractive as partners in international trade and politics. And, it is in particular a possibility for new 
democracies to demonstrate an enhanced credibility towards international and domestic actors and to show the willingness to strengthen peace and democracy (Moravcsik. 2000 Simmons/Danner, 2010). However, the level of ratification a state has already made matters the most, since a strong ICC would mean a high risk for states that have comparatively low levels of commitment to humanitarian law and human rights such as USA, India or Indonesia.

Seen in this way, the USA is not necessarily an outlier in its behavior towards the ICC. Although it is a democracy it has very bad rates of ratification to human rights (5 of 18) and humanitarian law (16 of 24). It can be argued that due to the states' domestic interests and preferences, different incentive structures to the ICC arise and thus different needs for committing to the ICC.

Strong democracies with a high level of commitment to humanitarian law and human rights, such as Germany, Belgium or the Netherlands, benefit considerably from the improvement in international peace and security through increased monitoring and enforcement of international criminal law. States that have a lower level of political freedom, such as Afghanistan, Ivory Cost or Cambodia; or states that have a high level of political freedom, but a comparatively low level of commitment to humanitarian law and human rights, such as the USA or India, are not necessarily interested in the international strengthening of monitoring humanitarian law and human rights or even in permanently enforcing international criminal law.

States that have both a low level of political freedom and low commitment to humanitarian law and human rights, such as Iran, Syria, North Korea, obviously have no incentives for increasing the monitoring and enforcement of international criminal law 94

For some the delegation dilemma that the ICC creates is very real issue because they are struggling with conflicting interests and have to protect themselves. Other states either have no interest or weak interest in increasing the monitoring and enforcement of humanitarian law and human rights. Or, their interest is so strong that they have hardly any need to constrain and customize their commitments.

Most of the states find themselves caught between the two poles of complete rejection and complete submission. There is high variation in the extent of self-binding among those states that are party to the ICC. The vast majority of states are torn between

$94[$ Sikkink (2011 189ff.) considers the dismissive attitude of the USA towards the ICC as impact of the 'justice cascade' insofar that the USA has reason to fear the new universal norms regarding the potential prosecution US-soldiers in international conflicts and relating to consideration and practices of torture and death penalty. 
contradictory interests. Since states have diverging political structures and positions, the actual incentives for the individual state vary widely.

Every state has to weigh freedom and security on the domestic and international level. They have to struggle with balancing their own interests and preferences against the potential costs and risks of becoming a state party to the ICC. Even if, we accept that the ICC is the peak of a long process in ending global impunity, we must consider that states' behavior to the ICC depend on their position to humanitarian law and human rights law and their chance in solving cooperation problems of international law. 


\section{An Index as Summary Measurement for Comprehensive Commitment}

In the following chapter, the Index of Commitment to the ICC will be conceptualized. It is intended to serve as a measuring device for the states' comprehensiveness of commitments to the court beyond the ratification of the Rome Statute. It provides evidence on the variation of the states' extent of commitment within the group of states parties to the ICC, and thus supports the theoretical argument of states constraining and customizing their commitments to the court.

In order to build the index of comprehensive commitment, different ways of customizing and constraining commitments to the ICC will initially be modeled 4.1). Afterwards, the case selection and data will be presented, and the methods of data collection and analysis will be set out (4.2). Finally, the results of building the INDEx of Commitment то тне ICC will be presented 4.3 and some notable patterns of commitment will be highlighted.

\subsection{Modeling Ways of Constraining and Customizing Commitments}

States can be expected to use all possibilities of constraint and customization of their commitments to the ICC when attempting to protect their sovereignty for the purpose of forestalling politicization and legal overreach of the court and retaining a certain room for maneuver towards the other states 95 By focusing on those possibilities of constraining and customizing commitments that are available for all states, the following possibilities can be identified (see Table 5): JOINING (DIM1) refers to the signature and ratification of the founding treaty; AMENDING (Dim2) means the signature and ratification of the additional and amending agreements; MODIFYING (Dim3) signifies making declarations and reservations of the agreements; IMPLEMENTING (Dim4) refers to the integration of norms into national law; and TRIGGERING (DIM5) means initiating the court's investigations. By measuring this it becomes possible to show that states concurrently move closer to the court and protect their sovereignty.

In principle, this model can be applied to all international courts that are permanent and go beyond mere dispute settlement, such as the the regional human rights courts or the courts of justice of the regional organizations 96

95 For a detailed illustration of the theoretical argument and the conceptualization of constrained and customized commitments to the ICC see subsection 3.4 on p. 123

96 Actually we can expect those indicator being true for international dispute settlement mechanisms, such as the WTO-DSB or the International Center for Settlement of Investment 
JOINING (Dim1)

AmENDing (Dim2)

MODIFYING (Dim3)

IMPLEMENTING (Dim4)

Triggering (Dim5)
Did a state ratify the founding treaty becoming a party state? Did a state ratify the additional and amending agreements? Did a state make reservations or interpretative declarations? Did a state implement material/formal norms into national law? Did a state trigger investigations and/or proceedings?

Table 5: Modeling Comprehensive Commitments to International Courts

In the case of the ICC, the following indicators (as shown in Table 6 measure the dimensions of commitment to the ICC: joining the Statute of Rome (DIM1); joining the APIC as well as the amendments on article 8 and the crime of aggression (DIM2), making reservations or interpretative declarations to the mentioned agreements (DIM3), implementing norms on cooperation and complementarity (DIM4) and triggering investigations and prosecutions (Dim5).

\subsubsection{Joining the Rome Statute (Dim 1)}

In the case of the ICC, it is the Rome Statute ${ }^{97}$ that establishes the ICC as "a permanent institution (...) [that] shall have the power to exercise its jurisdictions over persons for the most serious crimes of international concern (...) complementary to national jurisdiction" (art. 1). In order to become a state party to the ICC, states have to sign and ratify the Rome Statute 98 According to article 125, the Rome Statute is "open to accession by all States".

Disputes (ICSID), too. However, because of their ad-hoc character and the high level of flexibility of dispute settlement mechanisms, the indicators would probably not be sufficient measuring commitment.

97 The Statute of Rome of the ICC is composed by the following parts: Establishment of the Court (Part I); Jurisdiction, Admissibility and Applicable Law (Part II); General Principles of Criminal Law (Part III); Composition and Administration of the Court (Part IV), Investigation and Prosecution (Part V); The trial (Part VI); Penalties (Part VII); Appeal and Revision (Part VIII); International Cooperation and Judicial Assistance (Part IX); Enforcement (Part X); Assembly of States Parties (Part XI); Financing (Part XII) and Final Clauses (Part XIII)

98 To become a state party to the Rome Statute of the ICC it is not necessary to sign and later ratify. It is also possible to approve, accept, accede or succeed instead, which does not require the act of signature. For reasons of clarity, in the following, all of these actions are labeled as ratification. 


\begin{tabular}{|c|c|}
\hline Dimension & $\mathrm{ICC}$ \\
\hline JoINING (DIM 1) & Rome Statute of the ICC, Rome 1998 \\
\hline AMENDING (DIM 2) & $\begin{array}{l}\text { Agreement on Privileges and Immunities of the ICC, New York } 2002 \\
\text { Amendment to Article } 8 \text { of the Rome Statute, Kampala } 2010 \\
\text { Amendments on the Crime of Aggression to the Rome Statute, Kampala } 2010\end{array}$ \\
\hline MODIFYING (DIM 3) & $\begin{array}{l}\text { Rome Statute of the ICC, Rome } 1998 \\
\text { Agreement on Privileges and Immunities of the ICC, New York } 2002 \\
\text { Amendment to Article } 8 \text { of the Rome Statute, Kampala 2010 } \\
\text { Amendments on the Crime of Aggression to the Rome Statute, Kampala } 2010\end{array}$ \\
\hline IMPLEMENTING (DIM 4) & $\begin{array}{l}\text { Norms on Cooperation } \\
\text { Norms on Complementarity }\end{array}$ \\
\hline Triggering (Dim 5) & $\begin{array}{l}\text { State Referral of Party States (art. } 14 \text { Rome Statute) } \\
\text { Temporarily Submission of Non-Party States (art.12(a) Rome Statute) }\end{array}$ \\
\hline
\end{tabular}

Table 6: Modeling Customized and Constrained Commitments to the ICC

On the evening of July 18, 1998 at the Conference of Rome, 26 states became signatories to the Rome Statute 99 As of October 1998, there were 53 signatories. Four years later, on April 11 in 2002 the UN held a special treaty ceremony where several states (Democratic Republic of Congo, Niger, Cambodia, Jordan, Mongolia, Bosnia and Herzegovina, Bulgaria, Romania, Slovakia and Ireland) ratified the Rome Statue and thereby crossing the threshold of 60 ratifications. On July 1, 2002, the Rome Statute of the ICC entered into force. In 2016 there were 124 states parties to the Rome Statute.

\subsubsection{Amending APIC, Art. 8 and Crime of Aggression (Dim 2)}

There are three additional and amending agreements to the Rome Statute that are included in the Index of Commitment to the ICC: "the Agreement on the Privileges and Immunities of the International Criminal Court", "the Amendment to article 8 of the Rome Statute" and "the Amendments on the Crime of Aggression to the Rome Statute".

On 9 September 2002, the Assembly of State Parties adopted the Agreement on the Privileges and Immunities of the International Criminal Court. After ten

99 States that have signed immediately on July 17/18 1998 are: Albania, Bolivia, Cameroon, Congo, France, Georgia, Ghana, Greece, Italy, Liberia, Liechtenstein, Madagascar, Mali, Malta, Monaco, Netherlands, Niger, Panama, Samoa, San Marino, Senegal, South Africa, Spain, Switzerland, Zambia, Zimbabwe. 
states had ratified the agreement, it entered into force on 22 July 2004. The APIC is laid out in article 48 of the ICC-Statute [Privileges and immunities]: "The Court shall enjoy in the territory of each State Party such privileges and immunities as are necessary for the fulfillment of its purposes" (art.48(1) ICC-Statute). In addition to article 48 of the Rome Statute it covers certain privileges and immunities for staff and officials, as well as experts and witnesses.

Why are additional agreements to the Statute of Rome necessary? The ability to carry out investigations and prosecutions is dependent on the possibility of operating unhampered within the states and to receive assistance from the governments concerned. Usually privileges and immunities are embedded in the constitutive agreement of an international or regional organization. According to Mochochoko (2001), the main reason for codifying those rules in an additional agreement is that the ICC is (unlike the ICTY and the ICTR) independent from the UNO and cannot benefit from the privileges and immunity of the UNO, such as free communication via secure information channels or facilitated traveling through laissez-passer documents or sealed bags. However, punishing those responsible for war crimes, genocide or crimes against humanities outs staff members, experts or witnesses in very precarious situations. They need protection through certain privileges and immunities (Mochochoko, 2001, 639ff.). While article 48 of the ICC-Statute addresses the issue of privileges and immunities in general, the amendment agreement defines related obligations in detail.

The agreement grants the ICC special privileges during its investigations of the territories of the states parties, such as exemption from taxes, customs duties and import and export restrictions (art.8); reimbursement of duties and/or taxes (art.9); funds and freedom from currency restrictions (art.10); facilities in respect to communications (art.11); exercise of the functions of the Court outside its headquarters (art.12).

Property and possession with special protection are e.g. premises of the Court (art. 4); flag, emblem and markings (art.5); and property, funds and assets (art.16). Persons that enjoy privileges and immunities are e.g. representatives of states participating in the assembly and its subsidiary organs and representatives of intergovernmental organizations (art.13) or persons participating in the proceedings of the Court (art.14); judges, prosecutor, deputy prosecutor and registrar (art.15) or witnesses (art.19) and victims (art. 20).

"The Agreement should thus be seen as yet another milestone in the codification of international law of criminal tribunals and as yet another step in defining the privileges and immunities that are necessary for a permanent Criminal Court as well as for persons connected with it to carry out their functions effectively and without interference. (...) 
Universal ratification and early entry into force of the agreement will be as important as ratification to the Statute itself." (Mochochoko, 2001 663f.)

The APIC is open for signature and ratification to all states worldwide, not only to States Parties to the ICC. Thus, we can consider the states decision to be bound to the APIC as an important indicator for the commitment to the ICC in general.

"Whilst it is hoped that all States Parties to the Statute will ratify the Agreement, difficulties could arise if one or more States Parties do not ratify the Agreement. It can, however, be safely argued that the Statute sets out the basic parameters for the application of the Agreement and determines the legal status and privileges and immunities the Court needs to function effectively." (Mochochoko 2001 641)

Moreover, there are three amendments to the Rome Statute of the ICC: the amendment to article 8 (Kampala 2010), the amendments on the crime of aggression (Kampala 2010) and amendment to article 124 (The Hague 2015). Article 123(1) of the Statute of Rome says:

"Sven years after the entry into force of this Statute the Secretary-General of the United Nations shall convene a Review Conference to consider any amendments to this Statute. Such review may include, but is not limited to, the list of crimes contained in article 5 . The Conference shall be open to those participating in the Assembly of States Parties and on the same conditions."

In the Rome Statute, it is required that "an amendment shall enter into force for all States Parties one year after instruments of ratification or acceptance have been deposited with the Secretary-General of the United Nation by seven-eighths of them" (art.121(4) Rome Statute). Every state is allowed to propose amendments. The ASP decides if the proposal shall proceed and with a two-third-majority if the proposal shall be accepted. Article 121(5) (Rome Statute) says: "In respect of a State Party which has not accepted the amendment, the Court shall not exercise its jurisdiction regarding a crime covered by the amendment when committed by that State Party's nationals or on its territory."

In accordance with the VCLT every state party to the Rome Statute is entitled to become a state party to its amending agreements (art. 4 VCLT) and they are not bound by them once they have agreed to become a state party via the assigned requirements (art. 5 VCLT). It is required that every state joins the amendments having followed the same formalities as they did upon joining the Rome Statute.

The amendment to article 8 was adopted at the first Review Conference of the Rome Statute in Kampala 2010 and entered into force in 2012. It extends the definition of war crimes according to article 8 (2) (b) on non-international armed conflicts. 
Add to article 8 (para. (2) (e) (xiii)):

"(xiii) Employing poison or poisoned weapons;

(xiv) Employing asphyxiating, poisonous or other gases, and all analogous liquids, materials or devices;

(xv) Employing bullets which expand or flatten easily in the human body, such as bullets with a hard envelope which does not entirely cover the core or is pierced with incisions."

Moreover, there are additions to the elements of crimes with respect to the war crime of employing poison or poisoned weapons (art. 8 (2) (e) (xiii)), the war crime of employing prohibited gases, liquids, materials or devices (art.8 (2) (e) (xiv)), and the war crime of employing prohibited bullets (art. 8 (2) (e) (xv)).

The amendments on the crime of aggression, also adopted in Kampala 2010, defines the crime of aggression (art. 8 bis) and covers the exercise of jurisdiction over the crime of aggression (art.15 bis, art. 15 ter). Already at the Rome Conference in 1998, it had been stated that the ICC has jurisdiction over the crime of aggression (art. 5(1) ICC-Statute). Both the definition of the crime of aggression and conditions of jurisdiction were postponed, and art. 5 (2) says: "The Court shall exercise jurisdiction over the crime of aggression once a provision is adopted in accordance with articles 121 and 123 defining the crime and setting out the conditions under which the Court shall exercise jurisdiction with respect to this crime. Such a provision shall be consistent with the relevant provisions of the Charter of the United Nations."

At the first review conference in Kampala 2010, this challenge was mastered, and the crime of aggression was defined. Further, the conditions of jurisdiction were specified. The foundation of the definition of the crime of aggression as described in the UN General Assembly Resolution 3314 states:

\footnotetext{
"Aggression is the use of armed force by a State against the sovereignty, territorial integrity or political independence of another State, or in any other manner inconsistent with the Charter of the United Nations, as set out in this Definition." (Art.1 A/RES/3314)
}

Thus, the definition of aggression in the Rome Statute is fundamentally equal to the UN-Resolution (Barriga, 2010) when it says:

\footnotetext{
The 'crime of aggression' means "the planning, preparation, initiation or execution by a person in a position effectively to exercise control over or to direct the political or military action of a State, of an act of aggression which, by its character, gravity and scale, constitutes a manifest violation of the Charter of the United Nations." (Art. 8bis (1), amendment to the ICC-Statute)
}

To be differentiated from this is the 'act of aggression', meaning: 
"the use of armed force by a State against the sovereignty, territorial integrity or political independence of another State, or in any other manner inconsistent with the Charter of the United Nations." (art. 8bis (2), amendment to the ICC-Statute)

Such 'acts of aggression' include but are not limited to the following: invasion, attacks or bombardments by armed forces on land, sea or air both as military occupation or blockades of ports or coasts. According to Ambos $(2010,654)$ the crime of aggression has a twofold nature that covers a collective act of aggression by a state of the macro-level on one hand and an individual crime of aggression on the other. Thus, the existence of an illegal act of aggression according to art. 8bis Rome Statute on the basis of UN resolution 3314 does not lead automatically to criminal responsibility. The wording "act of aggression which, by its character, gravity and scale, constitutes a manifest violation of the Charter of the United Nations" establishes threshold provisions ensuring that not every act of aggression leads to a crime of aggression. This is meant to avoid the criminalization of minor incidents like border skirmishes or controversial cases like humanitarian interventions (Ambos, 2010, 655).

Besides the definition of the crime of aggression, the exercise of jurisdiction over the crime of aggression by state referral and proprio motu proprio motu (art. 15bis of the amendment to the ICC-Statute) and by Security Council referral (art. 15ter, amendment to the ICC-Statute) is established. The decoupling of the jurisdiction from the definition of the crime of aggression is due to the fact that otherwise the result would have been that the UNSC would have been able to trigger the investigation and prosecution of a crime of aggression. Thus, avoiding the risk of politicization, the definition of the crime of aggression and the jurisdiction over it was separated in different amending articles (Ambos, 2010, 663).

On the basis of UNSC referral, it is possible to investigate and prosecute crimes of aggression as well as the other three core crimes genocides, crimes against humanity and war crimes in states parties. Without an UNSC referral, the jurisdiction over the crime of aggression is based on the principle of consensus, whereby party states can opt out via declaration. States not parties are generally not subject to the jurisdiction of the court. Whether being offender or offended state, it is not possible to refer a situation ex post facto according to art. 12. This is in contrast to the other three core crimes. Moreover, the states agreed to activate both forms of jurisdiction (15bis and 15ter) in 2017 via a 2/3 majority (Barriga, 2010, 647).

In sum, we can say that the requirements for the jurisdiction are very high: A crime of aggression has to be of exceptional gravity and scale (threshold clause), it has to be in accordance with the UN Charter (A/Res/3314); it has to be committed 'by a 
person in a position effectively to exercise control' (limitation on political leaders); its jurisdiction is only possible over states that are parties to the Rome Statute and that have not withdrawn by way of declaration, and it needs a UNSC referral or a consensus of the states parties to trigger investigations and prosecutions 100

Although the requirements for the existence of a crime of aggression are very high, we can expect states being very restrained in the ratification of the amendment on the crime of aggression. This is due to the conditions for investigation and prosecution of a crime of aggression being so hard. We can consider this as an indicator that states are very restrained towards the amendment on the crime of aggression. Either way, we can interpret the ratification as very strong commitment to the ICC.

\subsubsection{Modifying APIC, Art. 8 and Crime of Aggression (Dim 3)}

Article 120 of Rome Statute says: "No reservations may be made to this Statute". Irrespective of their legal validity, we can nevertheless find several declarations and reservations to the Rome Statute.

As official exception we can consider article 124 [transitional provision ${ }^{101}$ that says:

\footnotetext{
"[O]n becoming a party to this Statute, [a state party] may declare that, for a period of seven years after the entry into force of this Statute for the State concerned, it does not accept the jurisdiction of the Court with respect to the category of crimes referred to in article 8 when a crime is alleged to have been committed by its nationals or on its territory. A declaration under this article may be withdrawn at any time."
}

Human rights agreements, agreements on the law of war and thus agreements of international criminal courts and tribunals share a civilizing and humanitarian purpose. The states parties to those agreements do not have particular interests that shall be balanced against each other, but they have one common interest. There is a broad consensus that reservations are not allowed to affect the purpose of an international agreement. So it is not in the sense of the raison d'être of human rights and humanitarian law to make reservations on their treaties.

\footnotetext{
100 For details and comprehensive discussion on the crime of aggression see Kreß (2010); Paulus (2010); Ambos (2010); Barriga (2010); Clark (2010).

101 Use of article 124 was only made by Colombia and France, whereby France, however, withdrew its declaration under article 124 that made upon ratification on 13 August 2008. With the 'amendment to article 124' (The Hague 2015), that is not yet in force, article 124 shall be deleted. However, since the amendment to article 124 was adopted in 2015 while the time of measurement of the dependent variable is 2016 and of the independent variables is 2015, it is not included in the dimension of amending of the Index of Commitment to the ICC.
} 
This explains why the article 120 [Reservations] of the Rome Statute comprises only one sentences that says: "No reservations may be made to this Statute"

Nevertheless, there are several states parties that made interpretative declarations to the Rome Statute that border on reservations according to Newman (2005, 325ff.). He refers especially to the declarations of Columbia that declared upon ratification:

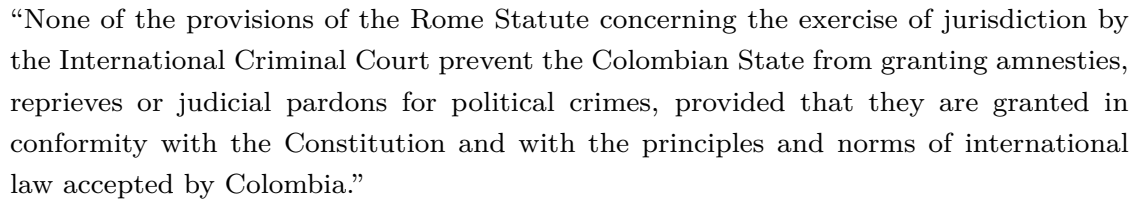

He argues that although reservations are prohibited and they are automatically invalid according to the Rome Statute article 120 and the VCLT article 19, interpretative declarations can become problematic.

\begin{abstract}
"An accumulation of interpretative declarations could subtle promote certain interpretations of the Rome Statute differing from those one might otherwise expect. (...) On standard principles of treaty interpretation, subsequent practice by parties to a treaty can affect the appropriate interpretation of treaty provisions. Consequently, the possibility of shifts in meaning must be presumed very real, simply under a slightly more nuanced legal doctrine. Of course there are also political maneuvers underway simultaneously, as states attempt politically to capture favored interpretations." (Newman 2005 ,332f.)
\end{abstract}

Fitzmaurice (2006, 170) believes that the ICC would be a real treaty sui generis, which its rules on reservations reflect. However, it is the same rule that generated a high number of interpretative declarations, of which some could be considered as reservations:

"This is a new phenomenon principally in relation to human rights (humanitarian) treaties, whereby the prohibition on reservations (...) compels States to make interpretative declarations, which are in fact disguised reservations."

Thus, notwithstanding the legal consequences of those interpretative declarations it is interesting to look at the interpretative declarations, since they can be considered as indicators for the fundamental attitude of the states towards the Rome Statute in that they are trying to protect their sovereignty against the ICC and thus reflecting the relative strength or weakness of their respective commitment to the ICC.

102 There are voices arguing that the prohibition of reservations is one reason that the USA refused to ratify the Rome Statute, see e.g. Schabas (2004 711). 


\subsubsection{Implementing Norms on Complementarity \& Cooperation (Dim 4)}

A further essential indicator for the comprehensiveness of commitment to the ICC is the implementation of norms into national law. The principle of complementarity plays an important role in the institutional design. Up until the creation of the ICC, international criminal tribunals were created ex post facto, thus after crimes committed in international armed conflicts. They had precedence over national jurisdiction. This was interalia justified by the fact that national and international jurisdiction are concurrent and international jurisdiction prevents national jurisdiction (Olásolo 2005). The ICC is consciously created to be complementary. This is meant to express that it respects state consent and the principle of sovereignty (Broomhall, 1999, 47). The implementation of the Rome Statute in national law can be considered as a very important condition for a good cooperation between the States Parties and the ICC (Broomhall, 1999, 79). Here we can distinguish between implementation of legislation on complementary and implementation of legislation on cooperation.

The Rome Statute itself requires no obligatory implementation of the norms of the ICC. It is solely intended in article 70(4) that the member states may add the protection of the court in their national rulings:

Art. 70 [Offences against the administration of justice] (4)a says: "Each State Party shall extend its criminal laws penalizing offences against the integrity of its own investigative or judicial process to offences against the administration of justice referred to in this article, committed on its territory, or by one of its nationals"

States have to make national arrangements, if they want to fulfill their commitment to the ICC (Broomhall, 1999; Ambos, 2011). Broomhall (1999) justifies the high importance of implementation with the ICC depending on state cooperation. He describes two main issues in the relationship of the ICC and state parties: "complementarity and cooperation, or investigation and prosecution by national justice systems of crimes within the jurisdiction of the Court, and cooperation by States in the Court's exercise of jurisdiction" (Broomhall, 1999, 79).

The complementarity of the ICC results inter alia of art. 1 that says: "[The ICC] shall be a permanent institution and shall have the power to exercise its jurisdiction over persons for the most serious crimes of international concern, as referred to in this Statute, and shall be complementary to national criminal jurisdictions." Further in art. 17(3) it says:

\footnotetext{
"In order to determine inability in a particular case, the Court shall consider whether, due to a total or substantial collapse or unavailability of its national judicial system,
} 
the State is unable to obtain the accused or the necessary evidence and testimony or otherwise unable to carry out its proceedings."

The obligation to cooperate results from article 86, Rome Statute: "States Parties shall, in accordance with the provisions of this Statute, cooperate fully with the Court in its investigation and prosecution of crimes within the jurisdiction of the Court.". Furthermore, there is the obligation to establish national procedures for this cooperation (art. 88 ICC): "States Parties shall ensure that there are procedures available under their national law for all of the forms of cooperation which are specified under this Part.", and the obligations of implementation in the sense of the principle of complementary (art. 17 ICC).

Thus, implementation in national law have to be made mainly as legislation on complementarity and cooperation. Broomhall (1999) sees the changes one state has to make being dependent on its constitutional and legal structure. While some states would have to make none or hardly any changes, others would have to override to some extent their own national legislation. Ambos (2011, 126ff.) stresses that these de facto obligations lead to a zero-solution in the form of a non-implementation being improbable, but he sees herein considerable room for maneuver. A limited implementation would be in the form of the introduction of procedural and administrative requirements. The maximal solution would be the complete implementation in form of an explicit reference to the Rome Statute or a codification.

The NGO Coalition for the International Criminal Court (CICC) also points out the relation between implementation and a successful cooperation:

\footnotetext{
"Given that the Court has no police force or prison, it will rely heavily on state cooperation in this regard. Specifically, States must adopt legislation which provides for the following: the Court to sit in the territory of a State Party; the criminalization of offenses against the ICC's administration of justice; the taking of evidence; the execution of searches and seizures; the arrest and surrender of persons; certain immunities for ICC officials; and provisions for penalties and enforcement." (CICC 2016
}

\subsubsection{Triggering Investigations and Prosecutions (Dim 5)}

The triggering of an investigation and prosecution by referral of a situation by a State Party (art.14) or by temporary submission to the Rome Statute by a Non-State Party can be considered as a further indicator for a comprehensive commitment to the ICC, since it reflects a credible willingness to deal with the past.

\footnotetext{
103 See CICC Fact Sheet on Implementation: http://www.iccnow.org/documents/FS_CICC_Implementation_Legislation_en.pdf (27-04-2016).
} 
The dimension measures both in which states the ICC carries out investigations and preliminary examinations and which party triggered them. There are four ways to trigger investigations and prosecutions of committed crimes against humanity, war crimes and genocide

- Referral of a situation by a State Party (art.14)

- Initiation of investigation by the Chief-Prosecutor proprio motu (art.15)

- Referral of a situation by the UNSC pursuant to ch. VII of the UN charter (art. 13(b))

- Temporarily submission of a non-Party State (art.12, para. 3)

1) Referral of a situation by a State Party (art.13(a) and art.14 ):

"The Court may exercise its jurisdiction (...) if: (a) A situation in which one or more of such crimes appears to have been committed is referred to the Prosecutor by a State Party in accordance with article 14". (art.13(a))

Article 14 [Referral of a situation by a State Party] says:

"1. A State Party may refer to the Prosecutor a situation in which one or more crimes within the jurisdiction of the Court appear to have been committed requesting the Prosecutor to investigate the situation for the purpose of determining whether one or more specific persons should be charged with the commission of such crimes.

2. As far as possible, a referral shall specify the relevant circumstances and be accompanied by such supporting documentation as is available to the State referring the situation."

\section{2) Referral of a situation by the UN-Security Council (art. 13(b)):}

"The Court may exercise its jurisdiction (...) if: (b) A situation in which one or more of such crimes appears to have been committed is referred to the Prosecutor by the Security Council acting under Chapter VII of the Charter of the United Nations(...).(art. 13(b))"

In article 39, chapter VII of the UN-Charter it says :

"The Security Council shall determine the existence of any threat to the peace, breach of the peace, or act of aggression and shall make recommendations, or decide what measures shall be taken in accordance with articles 41 and 42 , to maintain or restore international peace and security"

104 Triggering investigation of the crime of aggression has not been fully resolved. In the Kampala compromise it was decided that for state referral and triggering proprio motu the UNSC first shall decide if there is a act of aggression (art.15bis(6)). If there is no such determination of aggression by the $\overline{\text { UNSC }}$ within six month the proceedings may continue (art. 15bis(8)). 


\section{3) Initiation of investigations proprio motu by the Prosecutor:}

"The Court may exercise its jurisdiction (...) if: (c) The Prosecutor has initiated an investigation in respect of such a crime in accordance with article 15." (art.13(c))

Article 15 [Referral of a situation by the Prosecutor] says in paragraph 1 and 2:

"1. The Prosecutor may initiate investigations proprio motu on the basis of information on crimes within the jurisdiction of the Court.

2. The Prosecutor shall analyze the seriousness of the information received. For this purpose, he or she may seek additional information from States, organs of the United Nations, intergovernmental or non-governmental organizations, or other reliable sources that he or she deems appropriate, and may receive written or oral testimony at the seat of the Court."

Additionally, there is a further indirect option triggering investigations via 'submission of a situation by non-party states' according to article 12, para. 3:

"If the acceptance of a State which is not a Party to this Statute is required under paragraph 2, that State may, by declaration (...), accept the exercise of jurisdiction by the Court with respect to the crime in question. The accepting State shall cooperate with the Court without any delay or exception in accordance with Part 9."

Opening investigations prorio motu empowers the ICC and makes it more independent. The option of UN-Security Council referrals provides the opportunity to intervene in particularly serious armed conflicts although or even when the state is not willing by itself to stop the violence. But if states refer situations voluntarily, this can be considered as very strong signal of commitment to the court. Even more if the state concerned is not even party to the ICC.

Nevertheless, it is counter-factual to some extent to ask who did not use the courts' investigatory power although it was possible. One of the main tasks of the ICC is to examine if there were violations of the Statute of Rome or not. So, it is hardly possible to decide which violations weren't examined without them being examined. The ICC is intended as complementary to national criminal jurisdictions. So even if there are violations of international criminal law, a state still has the possibility of national prosecutions. So, the following operationalization must be seen in this light. What shall be measured is: In which states would it have been possible to appeal the ICC? In which states did investigation occur and who initiated the investigation.

In sum, we can say that in all dimensions of commitment to the ICC, states have the possibility of deciding to behave along a continuum between full commitment and zero commitment. To become a state party still can be considered as the most important 
dimension of commitment, but all the other ways offer windows of opportunity of strengthening or weakening this commitment.

Interestingly, there is very little path dependency in the possibilities of protecting sovereignty among themselves. The possibility of modifying by making reservations, declarations and objections is only possible if a state has ratified the Statute of Rome or the amending agreements. All the other options are in principle open to all states - regardless if they are parties to the ICC or not. This is due to the demand of universality and the manifold creation of incentives participating the ICC-regime unless a state is party to the Rome Statute or not. It is thus possible for example to trigger investigations in the own country by the acceptance of the ICC's jurisdiction with respect to a certain crime in question (art.12(3) ICC-Statute). States that used this possibility are e.g. Palestine concerning the occupation of Palestinian territory in East Jerusalem or Ukraine concerning the suppression of the protest on the Maidan between 2013-2014.

According to the theoretical considerations on the states behavior customizing and constraining their commitments to the ICC, the following PrEsumptions on EXPECTED Levels of Commitment can be made:

Presumption A: Among the states-parties there are only a few states with a high or very high level of commitment to the ICC.

Presumption B: Among the states-parties, most states will have (strongly) customized and constraint commitments.

Presumption C: The non-party states to the ICC tend to have a low or very low level of commitment to the ICC and only few states show approximation to the ICC. 


\subsection{Data and Methods I - Dimension Reduction and Index Building}

\subsubsection{Case Selection and Data Set I}

In order to measure the level of commitment to the ICC as independent variable, a data set is created that comprises data on the five dimensions of comprehensive commitment for 195 states. Those include the 193 member states of the UN as well as the State of Palestine and Cook Islands 105

For purpose of this empirical study time of measurement is August 2016. Up to that point, the ICC had 124 states parties with the Ivory Coast (2013), Palestine (2015) and El Salvador (2016) being the last states parties to ratify in this time frame. The five dimensions on comprehensive and customized commitments to the ICC are operationalized along their different indicators and elements by coding treaty documents of the United Nations Treaty Series (UNTS) and reports of the CICC on states' behavior towards the ICC 106

The variables that measure the dimensions of JoIning (DIm1) and AMENDING (Dim2) are found in the database of the United Nations Treaty Series (UNTS). Those are states parties to the Rome Statute (Rome 1998), the Agreement on Privileges and Immunities of the ICC (New York 2002), the Amendment to Article 8 of the Rome Statute (Kampala 2010), and the Amendment on the Crime of Aggression (Kampala 2002).

The data on the indicators measuring Modifying (DIM3) via reservations and interpretative declarations to the Rome Statute as well as the additional and amending agreements is as well based on the UNTS Only those declarations are considered as relevant for the customization of commitments to the ICC that shield or try to shield the states from the ICC. Declarations that express additional assent to the ICC are excluded as e.g. Jordan, that declared "The Government of the Hashemite Kingdom of Jordan hereby declares that nothing under its national law including the Constitution, is inconsistent with the Rome Statute of the International Criminal Court". Also not captured are declarations according to article 103 "On the Role of the States in the enforcement of sentences of imprisonment" of the Rome Statute.

Those declarations considered protective are: the transitional provision (art.124); maintaining reprieves, amnesties and pardons; interpreting humanitarian law or core crimes; stressing the fight of terrorism; stressing the right of self-defense and the prin-

\footnotetext{
105 States that are not included because of a lack of data due to their controversial political recognition are e.g. Kosovo and Taiwan.

106 An overview on variables, coding and sources can is found in 'Database \& Codebook I: Index of Commitment (DV)' on p.248.
} 
ciple of complementarity; or, in the case of the APIC, constrain the immunity of ICC staff. However, it is not taken into account which of the declarations are legally tenable, since it is the purpose of the study to examine the commitment of states regardless of the actual legal and political consequences.

The data on Implementing (Dim4) is taken from the country reports of the CICC The CICC is TAN of about 2,500 $\mathbb{N G O}$; from 150 countries. The network tries to encourage non-party states to join the ICC and motivate party states to deepen legal integration and political support. They describe themselves working in partnership in order to:

"[a]dvocate for all states to become party the Rome Statute of the International Criminal Court; [a]dvance stronger national laws that deliver justice to victims of war crimes, crimes against humanity and genocide; [s]trengthen state support for and cooperation with the ICC; [e]nsure that the Court is fair, effective and independent; [m]ake justice visible; [p]romote global civil society voices on international justice; Build a global movement of justice advocates.'107

Monitoring the ICC and its states parties, the CICC gathers information and reports, such as official documents and reports of the ICC, governments, IOs and ROs; or reports and media statements on the behavior of states towards the ICC from NGOs like $\mathbf{A D}$ or Human Rights Watch (BRW). The coding of which states have implemented or are in the process of implementation of norms on cooperation or complementarity is based on the CICC's country reports.

It would have been even more scientifically valuable to measure the data on the dimensions of customized/constrained commitments on an annual basis. There is only rare information on the state of implementation of norms on cooperation and complementarity into national law. For many states there is hardly any information on their status of implementation. Hence, it is not possible to measure the level of customized/constrained commitments on an annual basis. It would have been possible to explain it with a 'time-series cross-section analysis' showing changes in the states' commitment behavior towards the ICC. Therefore, a summary of the years since the adoption of the Rome Statute has been chosen and the level of customized/constrained commitment is measured for one summarized time frame (July 1998 until August 2016).

"Uncertainty and limited data should not cause us to abandon scientific research. One the contrary: the biggest payoff for using the rules of scientific inference occurs precisely when data are limited, observation tools are flawed, measurements are unclear, and relationships are uncertain." (King et al. 1994, 10)

107 See CICC http://www . coalitionfortheicc .org/?mod=coalition (04-11-2017). 
Thus, the focus lies mainly in the differences between the individual pattern of commitment behavior towards the ICC for each of the 195 states.

The dimension of TRIGgerING (DIM5) is measured by looking at which states have initiated investigations and prosecutions of the ICC via state-referral (art.14) or via temporary submission (art.12(3)). The data is derived directly from the database of the ICC itself 108 However, since we can expect states only trigger investigations and prosecutions when they are involved in a probable violation of the core crimes, only states that have experienced an armed conflict after 2002 according to the BattleRelated Deaths Dataset of the UCDP are considered ${ }^{109}$ However, since we can expect states only trigger investigations and prosecutions when they are involved in a probable violation of the core crimes, only states that have experienced an armed conflict after 2002 according to the Battle-Related Deaths Dataset of the UCDP are considered.104

\subsubsection{Methods of Data Collection and Data Analysis I}

The data on Joining (Dim1) and Amending (Dim2) is gained by counting the numbers of signature and ratification. For the data on Modifying (Dim3), ImplementING (Dim4) and TRIGGERING (Dim5) a content analysis was made via hand-coding along the basis of the criteria mentioned above. In this way, for each state an individual pattern of commitment to the ICC becomes visible in a range from no commitment to low commitment ranging up to a high commitment. To make these patterns of commitment behavior comparable, the data is mapped in the Index of Commitment TO THE ICC as summary measurement.

Therefore, the different dimensions are weighted on the basis their importance for the court. This makes it possible to show the commitment behavior of states in an order from no commitment (0 points) up to full commitment (12 points). On an empirical level, this allows for comparison of the commitment behavior of the different states, and moreover helps to assess the level of commitment to the ICC as a whole 110

The concept of constrained and customized commitments to the ICC can be illustrated empirically. It is possible to deconstruct the dichotomy of states parties and non-states parties into different groups on the basis of their respective commitment levels. It provides a more fine-grained measurement of the extent of states' commitment to the

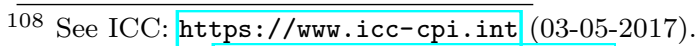

109 See UCDP http://ucdp.uu.se/downloads (26-09-2016).

110 All calculations and figures building and illustrating the Index of Commitment to the ICC are made with Microsoft Excel 15 and Stata IC/14.
} 


\begin{tabular}{|c|c|c|c|}
\hline Variable & $\mathbf{N}$ & Min & $\operatorname{Max}$ \\
\hline \multicolumn{4}{|l|}{ Joining (Dim 1) } \\
\hline SIgnature Rome Statute & 195 & 0 & 1 \\
\hline RATification Rome Statute & 195 & 0 & 1 \\
\hline \multicolumn{4}{|l|}{ Amending (Dim 2) } \\
\hline SIGNATURE APIC & 195 & 0 & 1 \\
\hline RATIFICATION APIC & 195 & 0 & 1 \\
\hline RATIFICATION ART8 & 195 & 0 & 1 \\
\hline RAtification Crime of Aggression & 195 & 0 & 1 \\
\hline \multicolumn{4}{|l|}{ Modifying (Dim 3) } \\
\hline mod. RomeStatute & 195 & 0 & 1 \\
\hline MOD. APIC & 195 & 0 & 1 \\
\hline MOD. ART8 & 195 & 0 & 1 \\
\hline \multicolumn{4}{|l|}{ Implementing (Dim 4) } \\
\hline COMPLEMENTARITY (PROGRESS) & 195 & 0 & 1 \\
\hline COMPLEMENTARITY (ISSUED) & 195 & 0 & 1 \\
\hline COOPERATION (PROGRESS) & 195 & 0 & 1 \\
\hline COOPERATION (ISSUED) & 195 & 0 & 1 \\
\hline \multicolumn{4}{|l|}{ Triggering (Dim 5) } \\
\hline STATE REFERRAL ART. $14 / 12($ A) & 195 & 0 & 1 \\
\hline
\end{tabular}

Table 7: Overview on Dimensions and Variables 
ICC. It shows that there are many ways of constraining and customizing commitments in order to protect sovereignty and still remain a state party.

The Index of Commitment to the ICC forms the Dependent variable, that can later be set in relation to different explanatory variables. That shows that the extent of commitment to the ICC depends on the earlier level of commitment to humanitarian law and human rights and the possibilities for states to reduce costs of monitoring humanitarian law and human rights and at the level of commitment. The methodological approach of building an index was chosen to create one single value for each state that reflects the states' level of COMPREHENSIVE COMMITMENT то тнE ICC. Thus, the latent variable of customized/constrained commitment can be operationalized by summarizing different dimensions and indicators of commitment to international courts. It is possible to compare the different levels of commitment of the states and it is possible to compare the different levels of commitment of the states.

The results of the index values can be taken as the basis for building a typology of commitment behavior towards the ICC. The choice of the dimensions follows the considerations above, namely that the five dimensions illustrate those ways of constraining and customizing commitments that are directly available to all states. They do not depend necessarily on the states' power capacity in international negotiations or their effort in political negotiations. This would be the case if states wanted to influence the institutional design of a court or the political standing towards the UNSC or other [Os or [ROs. According to this, the determination of the dimensions that enter into the index is a theoretical argument-based decision. Although there are other possible ways of choosing dimensions for an index, we can say that there are no objective quality criteria making it possible to assess if all relevant dimensions are taken into account or if those that are chosen are really relevant (Schnell et al. 2013, 158f.). The combination of indicators summarized to one dimension as well as the relation of the different dimension to each other, follows an arbitrary numerical reduction building an argument-based, weighted, additive index 111 A robustness check for this way of calculating the index points is provided in subsection $7.5^{112}$

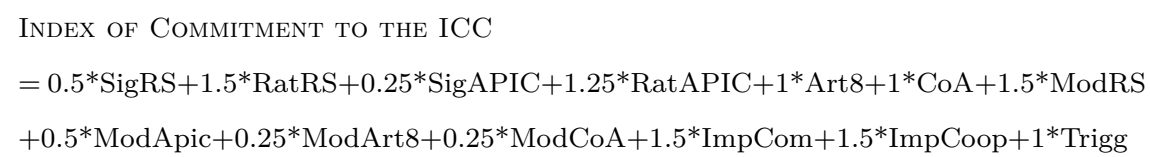

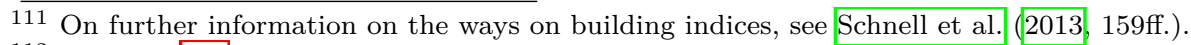
112 See on p. 241 
Joining the Rome Statute (Dim1) at the onset is scored with 2 points. Signing and ratifying the additional and amending agreements (Dim2) is scored much higher with 3.5 point due to the consideration that the full support of all agreements is a highly important indicator for the willingness of states to commit fully. The modification of commitments (Dim3) is scored with 2.5 points because having made no modifications demonstrates a high willingness to commit. Implementing (Dim4) is scored even higher as it can be considered as highly significant if the states even bind themselves legally by harmonizing their national laws to conform to the norms. Triggering (Dim5) is only scored with one point, since it is harder to initiate a legal process in times of political instability. Even more so because the ICC allows for two other ways of referral to trigger investigation. For the same reason, this dimension is not excluded but instead it is recognized if a state (that maybe is not even party to the ICC) triggers investigation. As a further condition, this dimension is adjusted by valuing states with 0 points that experienced an actual armed conflict since 2000 .

\begin{tabular}{|c|c|c|c|}
\hline Dimension & Variables & Scores/Variable & Scores/Dimension \\
\hline JOINING (DIM 1) & $\begin{array}{l}\text { signature Rome Statute } \\
\text { ratification Rome Statute }\end{array}$ & $\begin{array}{l}0.50 \\
1.50\end{array}$ & 2.00 \\
\hline AmENDING (Dim 2) & $\begin{array}{l}\text { signature APIC } \\
\text { ratification APIC } \\
\text { amendment to art. } 8 \\
\text { crime of Aggression }\end{array}$ & $\begin{array}{l}0.25 \\
1.25 \\
1.00 \\
1.00\end{array}$ & 3.50 \\
\hline MODIFYING (DIM 3) & $\begin{array}{l}\text { Rome Statute of the ICC } \\
\text { APIC } \\
\text { amendment to art. } 8 \\
\text { amendment to CoA }\end{array}$ & $\begin{array}{l}1.50 \\
0.50 \\
0.25 \\
0.25\end{array}$ & 2.50 \\
\hline IMPLEMENTING (DIM 4) & $\begin{array}{l}\text { cooperation (in progress/issued) } \\
\text { complementarity (in progress/issued) }\end{array}$ & $\begin{array}{l}(0.50 / 1.50) \\
(0.50 / 1.50)\end{array}$ & 3.00 \\
\hline TRIGGERING (DIM 5) & art. 14/art. 12(a) Rome Statute & 1.00 & 1.00 \\
\hline
\end{tabular}

Table 8: Scores of the Dimensions of the Index of Commitment to the ICC 


\subsection{Results I - The Index of Commitment to the ICC}

\subsubsection{Variation in the Different Dimensions of Commitment}

The basis of the Index of Commitment TO THE ICC are the states' achievements in the different dimensions of commitment. An overview of the frequencies of the states' results can be found in Table 9

\begin{tabular}{|c|c|c|c|}
\hline Variables & $\mathbf{N}$ & No & Yes \\
\hline \multicolumn{4}{|l|}{ Joining (Dim 1) } \\
\hline Sig. Rome Statute & 195 & $43(22.50 \%)$ & $152(77.95 \%)$ \\
\hline Rat. Rome Statute & 195 & $71(36.41 \%)$ & $124(63.59 \%)$ \\
\hline \multicolumn{4}{|l|}{ Amending (Dim 2) } \\
\hline SIG./ACC. APIC & 195 & $109(55.90 \%)$ & $86(44.10 \%)$ \\
\hline RAT./ACC. APIC & 195 & $120(38.46 \%)$ & $75(61.54 \%)$ \\
\hline RAT. ART 8 & 195 & $163(83.59 \%)$ & $32(16.41 \%)$ \\
\hline RAT. COA & 195 & $163(83.59 \%)$ & $32(16.41 \%)$ \\
\hline \multicolumn{4}{|l|}{ Modifying (Dim 3) } \\
\hline MOD. RomeStatute & 152 & $134(88.16 \%)$ & $18(11.84 \%)$ \\
\hline MOD. APIC & 86 & $62(72.09 \%)$ & $24(27.91 \%)$ \\
\hline MOD. ART8 & 32 & $32(100 \%)$ & $0(0 \%)$ \\
\hline MOD. COA & 32 & $32(100 \%)$ & $0(0 \%)$ \\
\hline \multicolumn{4}{|l|}{ Implementing (Dim 4) } \\
\hline LAW ON COMPLEMENTARITY & 195 & $91(46.67 \%)$ & $66(33.85 \%)$ \\
\hline ISSUED & & & $+38(19.49 \%)$ \\
\hline LAW ON COOPERATION & 195 & $117(60.00 \%)$ & $48(24.62 \%)$ \\
\hline ISSUED & & & $+30(15.38 \%)$ \\
\hline \multicolumn{4}{|l|}{ Triggering (Dim 5) } \\
\hline STATE REFERRAL ART. 14 / 12(A) & 67 & $60(\%)$ & $7(\%)$ \\
\hline
\end{tabular}

Table 9: Frequencies - Dimensions of Commitment 


\begin{tabular}{|c|c|}
\hline States Parties to the Rome Statute (124) & Non-Party States to the Rome Statute (71) \\
\hline $\begin{array}{l}\text { Afghanistan, Albania, Andorra, Antigua a. Barbuda, } \\
\text { Argentina, Australia, Austria, Bangladesh, Barbados, } \\
\text { Belarus, Belgium, Belize, Benin, Bolivia, Bosnia-Herz. } \\
\text { Botswana, Brazil, Bulgaria, Burkina Faso, Burundi, } \\
\text { CAfRep., Cambodia, Canada, Cape Verde, Chad, } \\
\text { Chile, Colombia, Comoros, Congo, Cook Islands } \\
\text { Costa Rica, Croatia, Cyprus, Czechia, DR Congo, } \\
\text { Denmark, Djibouti, Dominica, Dominican Republic, } \\
\text { Ecuador, El Salvador, Estonia, Ethiopia, Fiji, Finland, } \\
\text { France, Gabon, Gambia, Georgia, Germany, Ghana, } \\
\text { Greece, Grenada, Guatemala, Guinea, Honduras, } \\
\text { Hungary, Iceland, Ireland, Italy, Ivory Coast, Japan, } \\
\text { Jordan, Kenya, Republic of Korea, Latvia, Lesotho, } \\
\text { Liberia, Liechtenstein, Lithuania, Luxembourg, } \\
\text { Macedonia, Madagascar, Malawi, Maldives, Mali, } \\
\text { Malta, Marshall Islands, Mauritius, Mexico, Moldova, } \\
\text { Mongolia, Montenegro, Namibia, Nauru, Netherlands, } \\
\text { New Zealand, Niger, Nigeria, Norway, Palestine, } \\
\text { Panama, Paraguay, Peru, Philippines, Poland, } \\
\text { Portugal, Romania, Samoa, San Marino, } \\
\text { St.Kitts a. Nevis, St.Lucia, St.Vin. a. Grenadines, } \\
\text { Senegal, Serbia, Seychelles, Sierra Leone, Slovakia, } \\
\text { Slovenia, South Africa, Spain, Suriname, Sweden, } \\
\text { Switzerland, Tajikistan, Tanzania, Timor-Leste, } \\
\text { Trinidad a. Tobago, Tunisia, Uganda, Unit. Kingdom, } \\
\text { Uruguay, Vanuatu, Venezuela, Zambia }\end{array}$ & $\begin{array}{l}\text { signed, but not ratified (28) } \\
\text { Algeria, Angola, Armenia, Bahamas, Bahrain, } \\
\text { Cameroon, Egypt, Eritrea, Guinea-Bissau, Haiti, } \\
\text { Islamic Rep. of Iran, Jamaica, Kuwait, Kyrgyzstan, } \\
\text { Monaco, Morocco, Mozambique, Oman, Russia, } \\
\text { Sao Tome a. Principe, Solomon Islands, Syria, } \\
\text { Thailand, Ukraine, Arab Emirates, Uzbekistan, } \\
\text { Yemen, Zimbabwe } \\
\text { not signed (43) } \\
\text { Azerbaijan, Belarus, Bhutan, Brunei, China, Cuba, } \\
\text { Equatorial Guinea, Guyana, India, Indonesia, Iraq, } \\
\text { Israel, Kazakhstan, DPR Korea, Kiribati, Laos, } \\
\text { Lebanon, Libya, Malaysia, Mauritania, Micronesia, } \\
\text { Myanmar, Nepal, Nicaragua, Pakistan, Palau, } \\
\text { Papua New Guinea, Qatar, Rwanda, Saudi Arabia, } \\
\text { Singapore, Somalia, South Sudan, Sudan, } \\
\text { Sri Lanka, Swaziland, Togo, Tonga, Turkey, } \\
\text { Turkmenistan, Tuvalu, United States of America, } \\
\text { Vietnam }\end{array}$ \\
\hline
\end{tabular}

Table 10: States Parties and Non-Party States to the Rome Statute

JoINing THE ICC (Dimension 1): As pointed out at the beginning of the work, in 2016, 124 states had ratified the Rome Statute, while 71 states did not. Moreover, with the addition of those states that signed the Rome Statute we have 152 states as opposed to 43 states that did not sign. ${ }^{113}{ }^{114}$

Amending (Dimension 2): The Agreement on the Privileges and Immunities of the ICC of 2002 was ratified by 75 states. It is 86 states including those that have at least signed. The APIC is open for ratification by all states. The Ukraine as non-party state has ratified the agreement. As will later become apparent, the Ukraine shows further

113 In order to distinguish those that signed from those that did not, the variable of signature includes those that became party to the ICC via approval, acceptance, accession or succession, although these ways formally do not need the act of signature.

114 The time of measurement for the comprehensive and customized commitments is September 2016. On 30 November 2016 the Government of the Russian Federation notified that the would not become a state party to the ICC. In the present model it is still counted as a signature. Likewise Burundi is still considered as a state party although it declared on 26 October 2016 that it has decided to withdraw from the Rome Statute what took effect in October 2017. The same is true for the Philippines that withdrawal took effect in March 2019. South Africa (19 October 2016) and Gambia (10 November 2016) announced a withdrawal; both of them rescinded this decision in the beginning of 2017, see: https://treaties.un.org/pages/ ViewDetails . aspx?src=TREATY\&mtdsg_no=XVIII-10\&chapter=18\&clang=_en (05-05-2017). 


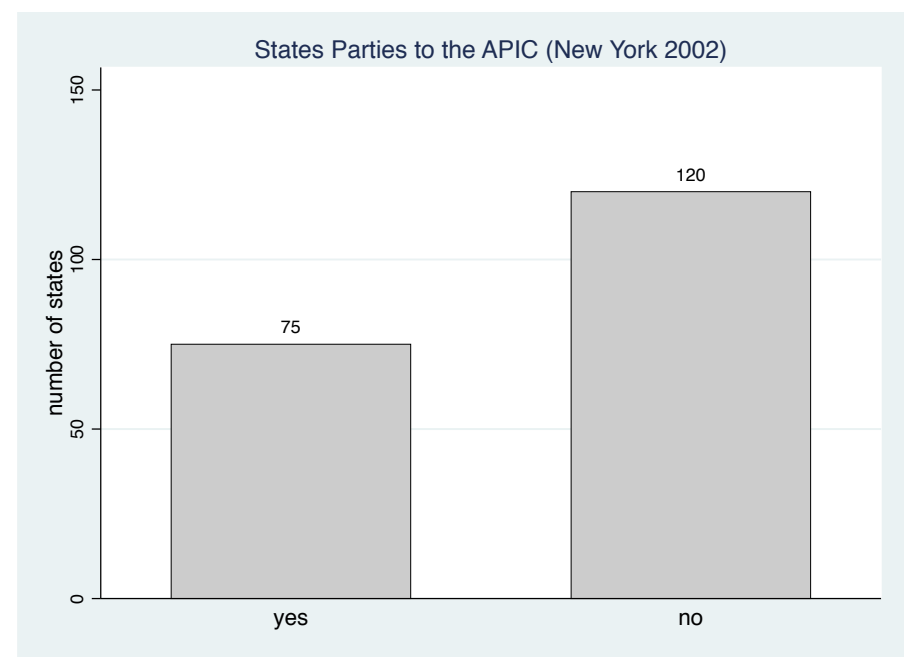

Figure 11: States Parties to the APIC

steps of rapprochement to the ICC despite being no party state. The Bahamas have signed the APIC although the state is also not party to the Rome Statute.

The amendment to article 8 and the amendment on the crime of aggression have (up to 2016) 32 states parties 115 However, it is not exactly the same 32 states in each case. Norway and Mauritius are states parties to the amendment to article 8, but not to the amendments on the crime of aggression. Conversely, the State of Palestine and Iceland are states parties to the amendments on the crime of aggression, but not to article 8 . Furthermore, we can see that both amendments are mainly ratified by democratic states. As Table 14 shows, among the states parties to the amendment to article 8 there are 2 non-democratic and 30 democratic states. Likewise, among the states that are party to the amendments on the crime of aggression there are 3 non-democratic and 29 democratic states (see Table 15).

Modifying (Dimension 3): There are several states that have made reservations, declarations and notifications upon signature or ratification of the Rome Statute. Among those, 18 modifications can be deemed indicators for the protection of sovereignty towards the ICC. In most of these modifications the states intention is to retain the privileges given through humanitarian law and still, e.g. to have the right to attack military targets or stress the national sovereignty.

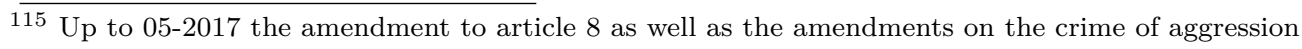
has with Argentina and Portugal 34 states parties. 


\begin{tabular}{|c|c|}
\hline States Parties to the APIC (75) & Non-Party States to the APIC (120) \\
\hline $\begin{array}{l}\text { Albania, Andorra, Argentina, Austria, Belgium, } \\
\text { Belize, Benin, Bolivia, Bosnia and Herzegovina, } \\
\text { Brazil, Botswana, Bulgaria, Burkina Faso, Canada, } \\
\text { CAfRep., Chile, Colombia, Congo, Costa Rica, } \\
\text { Croatia, Cyprus, Czech Republic, DR Congo, } \\
\text { Denmark, Dom. Rep., Ecuador, Estonia, Finland, } \\
\text { France, Gabon, Georgia, Germany, Greece, } \\
\text { Guyana, Honduras, Hungary, Iceland, Ireland, } \\
\text { Italy, Jamaica, Jordan, Latvia, Lesotho, Liberia, } \\
\text { Liechtenstein, Lithuania, Luxembourg, Macedonia, } \\
\text { Malawi, Mali, Malta, Mexico, Montenegro, } \\
\text { Namibia, Netherlands, New Zealand, Norway, } \\
\text { Palestine, Panama, Paraguay, Poland, Portugal, } \\
\text { Republic of Korea, Romania, Samoa, Senegal, } \\
\text { Serbia, Slovakia, Slovenia, Spain, Sweden, } \\
\text { Switzerland, Trinidad and Tobago, Tunisia, } \\
\text { Uganda, Ukraine, UK of Great Britain, Uruguay }\end{array}$ & $\begin{array}{l}\text { signed, but not ratified (11) } \\
\text { Bahamas, Ghana, Guinea, Jamaica, Jordan, } \\
\text { Madagascar, Mongolia, Peru, Sierra Leone, Tanzania } \\
\text { not signed (109) } \\
\text { Afghanistan, Algeria, Angola, Antigua and Barbuda, } \\
\text { Armenia, Australia, Azerbaijan, Bahrain, Bangladesh, } \\
\text { Barbados, Belarus, Bhutan, Brunei, Burundi, Cambodia, } \\
\text { Cameroon, Cape Verde, Chad, China, Comoros, Congo, } \\
\text { Cook Is., Cuba, Djibouti, Dominica, Egypt, El Salvador, } \\
\text { Equatorial Guinea, Eritrea, Ethiopia, Fiji, Gambia, } \\
\text { Grenada, Guatemala, Guinea-Bissau, Haiti, India, } \\
\text { Indonesia, Iran, Iraq, Israel, Ivory Coast, Japan, } \\
\text { Kazakhstan, Kenya, DR of Korea, Kiribati, Kuwait, } \\
\text { Kyrgyzstan, Lao PDR, Lebanon, Libya, Malaysia, } \\
\text { Maldives, Marshall Islands, Mauritania, Mauritius, } \\
\text { Micronesia, Moldova, Monaco, Morocco, Mozambique, } \\
\text { Myanmar, Nauru, Nepal, Nicaragua, Niger, Nigeria, } \\
\text { Oman, Pakistan, Palau, Papua New Guinea, Philippines, } \\
\text { Qatar, Russia, Rwanda, St. Kitts and Nevis, St.Lucia, } \\
\text { St. Vincent and the Grenadines, San Marino, } \\
\text { Sao Tome and Principe, Saudi Arabia, Seychelles, } \\
\text { Singapore, Solomon Islands, Somalia, South Africa, } \\
\text { South Sudan, Sri Lanka, Sudan, Suriname, Swaziland, } \\
\text { Syria, Tajikistan, Thailand, Timor Leste, Togo, } \\
\text { Tonga, Turkey, Turkmenistan, Tuvalu, UA Emirates, } \\
\text { United States of America, Uzbekistan, Vanuatu, } \\
\text { Vietnam, Yemen, Zambia, Zimbabwe }\end{array}$ \\
\hline
\end{tabular}

Table 11: States Parties and Non-Party States to the APIC

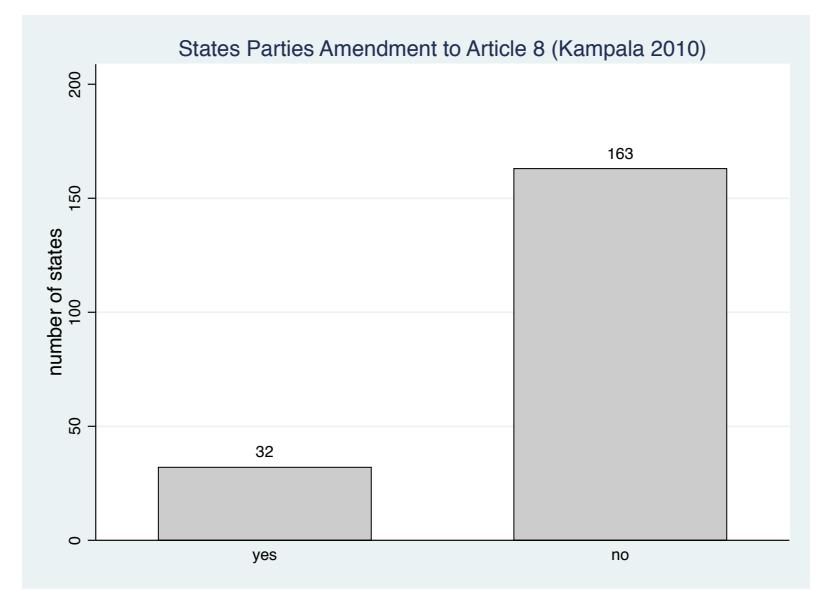

Figure 12: States Parties to the Amendment to Article 8 
States Parties to the Amendment to Article 8 of the Rome Statute (32)

Andorra, Austria, Belgium, Botswana, Chile, Costa Rica, Croatia, Cyprus, Czech Republic, El Salvador, Estonia, Finland, Georgia, Germany, Latvia, Liechtenstein, Lithuania, Luxembourg, Malta, Mauritius, Netherlands, Norway, Poland, Samoa, San Marino, Slovakia, Slovenia, Spain, Switzerland, Macedonia, Trinidad and Tobago, Uruguay

Table 12: States Parties to the Amendment to Article 8

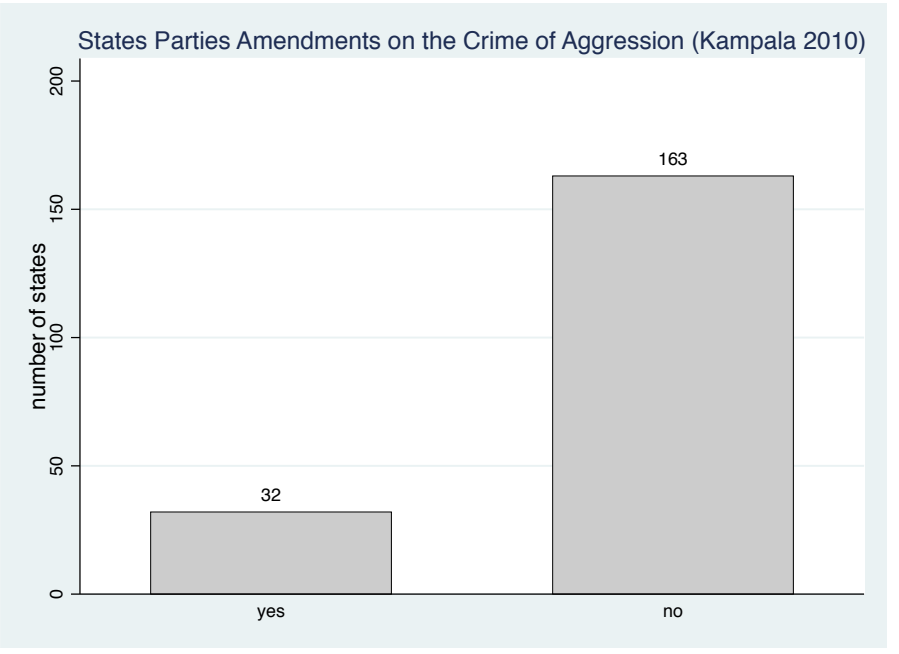

Figure 13: States Parties to the Amendment on the Crime of Aggression

States Parties to the Amendments on the Crime of Aggression (32)

Andorra, Austria, Belgium, Botswana, Chile, Costa Rica, Croatia, Cyprus, Czech Republic, El Salvador, Estonia, Finland, Georgia, Germany, Iceland, Latvia, Liechtenstein, Lithuania, Luxembourg, Malta, Netherlands, Palestine, Poland, Samoa, San Marino, Slovakia, Slovenia, Spain, Switzerland, Macedonia, Trinidad and Tobago, Uruguay

Table 13: States Parties to the Amendments on the Crime of Aggression

\begin{tabular}{c|cc|c} 
States Parties art. 8 & \multicolumn{2}{|c|}{ Democracy } & total \\
& no & yes & \\
\hline no & 107 & 56 & 163 \\
yes & 2 & 30 & 32
\end{tabular}

Table 14: States Parties Article 8 \& Democracy Dummy 2015 


\begin{tabular}{c|cc|c} 
States Parties CoA & \multicolumn{2}{|c|}{ Democracy } & total \\
& no & yes & \\
\hline no & 106 & 57 & 163 \\
yes & 3 & 29 & 32
\end{tabular}

Table 15: States Parties Crime of Aggression \& Democracy Dummy

Australia has declared:

"no person can be surrendered to the Court unless the Australian Attorney-General issues a certificate allowing surrender. Australian law also provides that no person can be arrested pursuant to an arrest warrant issued by the Court without a certificate from the Attorney-General."

Columbia has declared:

"None of the provisions of the Rome Statute concerning the exercise of jurisdiction by the International Criminal Court prevent the Colombian State from granting amnesties, reprieves or judicial pardons for political crimes, provided that they are granted in conformity with the Constitution and with the principles and norms of international law accepted by Colombia."

France has declared interalia:

"The provisions of article 8 of the Statute (...) relate solely to conventional weapons and can neither regulate nor prohibit the possible use of nuclear weapons nor impair the other rules of international law applicable to other weapons necessary to the exercise by France of its inherent right of self-defense".

With regard to the APIC there are 24 reservations, declarations and notifications that are made upon signature, ratification, acceptance, approval, accession or succession of agreement. Those entail mainly constraints on certain formalized privileges and immunities for citizens of their own state.

Implementing (Dimension 4): According to the data of the CICC, there are 66 states that have implemented national law on complementarity to the ICC and at least 38 that are in a process of preparing implementation (see Figure 14). There are 48 states that have implemented national law on cooperation with the ICC. At least 30 states are in the process of preparing implementation of norms on cooperation (see Figure 15). 


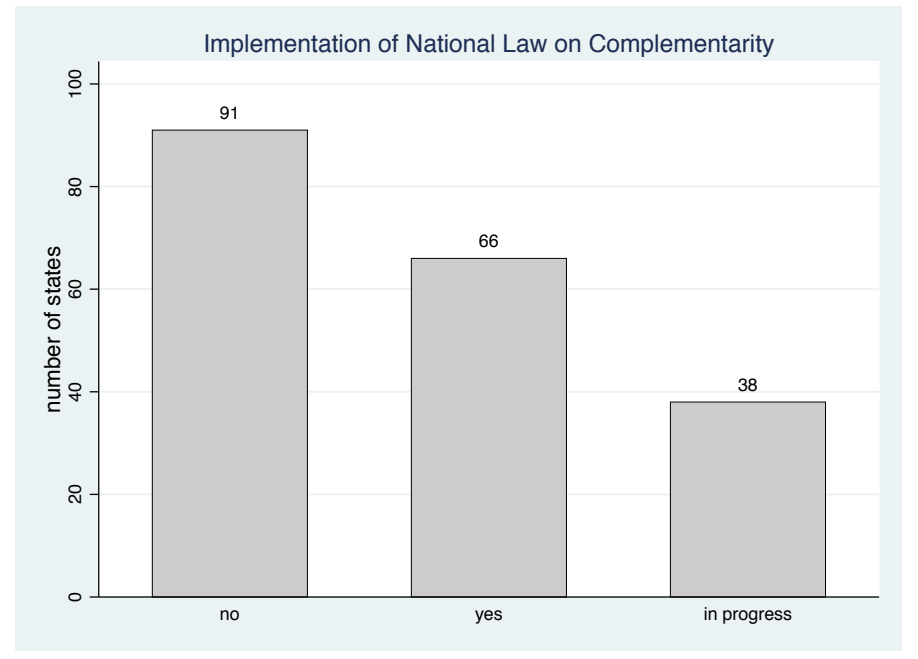

Figure 14: Implementation of Law on Complementarity to the ICC

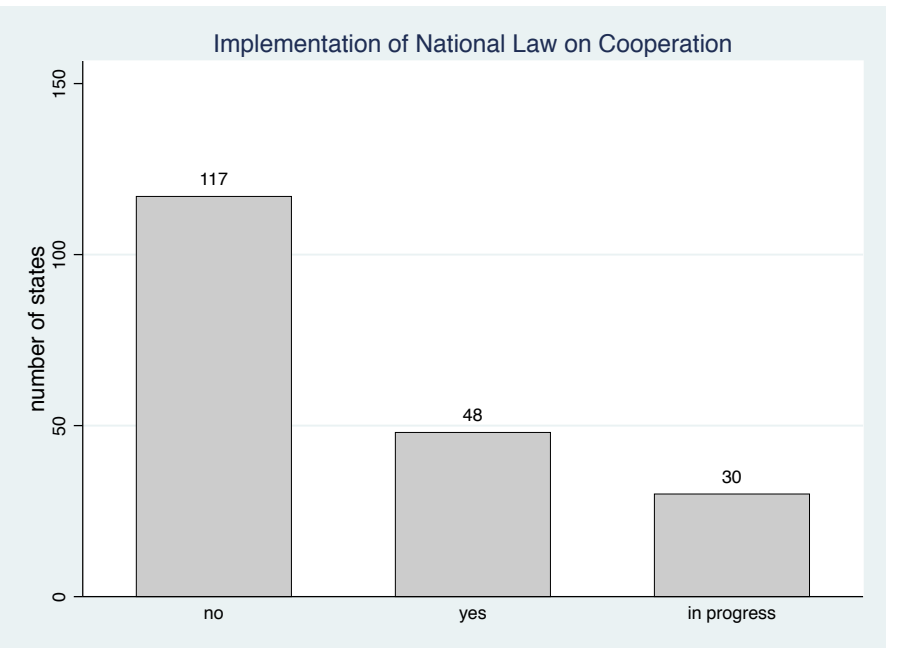

Figure 15: Implementation of Law on Cooperation with the ICC 
Triggering (Dimension 5): There are 7 states that have triggered investigations and prosecutions of the ICC on their own initiative, either pursuant to article 14 as state-referral (Democratic Republic of the Congo, Uganda, Central African Republic, Mali) or in accordance with article 12(3) by respecting the jurisdiction of the ICC as non-party state (Palestine, Ivory Coast, Ukraine)

States Parties Involved in Armed Conflicts 2000-2015 (28)

Burundi, Ivory Coast, Chad, Cambodia, Senegal, Djibouti, Bangladesh, Niger, Peru, Liberia, Afghanistan, Nigeria, Sierra Leone, Central African Republic, Republic Congo, Democratic Republic of Congo, Uganda, Palestine, Georgia, Philippines, Guinea, United Kingdom of Great Britain, Kenya, Tadjikistan, Mali, Colombia, Macdonia, Australia

Non-Party States Involved in Armed Conflicts 2000-2015 (35)

Pakistan, Iran, Turkey, Malaysia, Indonesia, Azerbaijan, Somalia, Sri Lanka, Eritrea, India, Thailand, Myanmar, Nepal, Angola, Syria, Israel, United States of America, Iraq, Ethiopia, Haiti, Lebanon, Libya, China, Egypt, Cameroon, Mozambique, Sudan, Mauritania, Yemen, Uzbekistan,

Russia, Rwanda, Algeria, South Sudan, Ukraine

Table 16: States Involved in Armed Conflicts 2000-2015 by Ratification Status

According to UCDP there have been armed conflicts since 2000 in at least 63 states worldwide (see Table 16). There are 56 states that have experienced an armed conflict have triggered no investigations on their own. However, this consideration has to be relativized insofar as the mere existence of an armed conflict does not mean there occurred one or more of the core crimes according to the Rome Statute. Nor can we conclude that such crimes have happened in those states that have triggered investigations by themselves according to article 14 and 12(3), since it is one central task of the ICC to examine if there were. Accordingly, the variable is only measures which states have used the possibility of investigations and prosecutions as one dimension of commitment to the ICC.

$\overline{116}$ Later on both Ivory Coast (in 2013) and the State of Palestine (in 2016) ratified the Rome Statute and became states parties to the ICC. 


\subsubsection{The Index of Commitment to the ICC}

Building the Index of Commitment to The ICC makes it possible to illustrate the states' results in the different dimensions of commitment as one central summary measurement. The states can receive values between 0 and 12 on a scale with 0.25 incremental steps (see Figure 16). As shown in Figure 17 there are 60 states that have 0 points and 135 states with index points between 0.25 and 12 points.

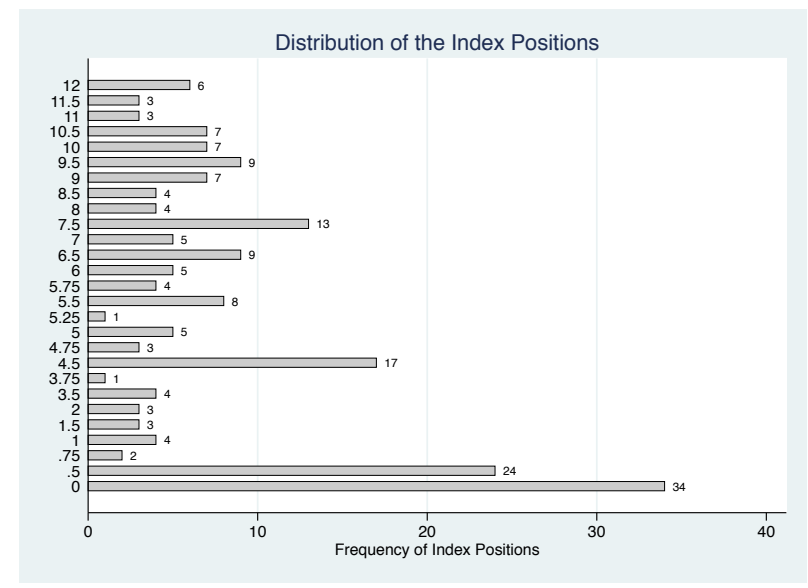

Figure 16: Frequency Distribution of the States' Index Positions

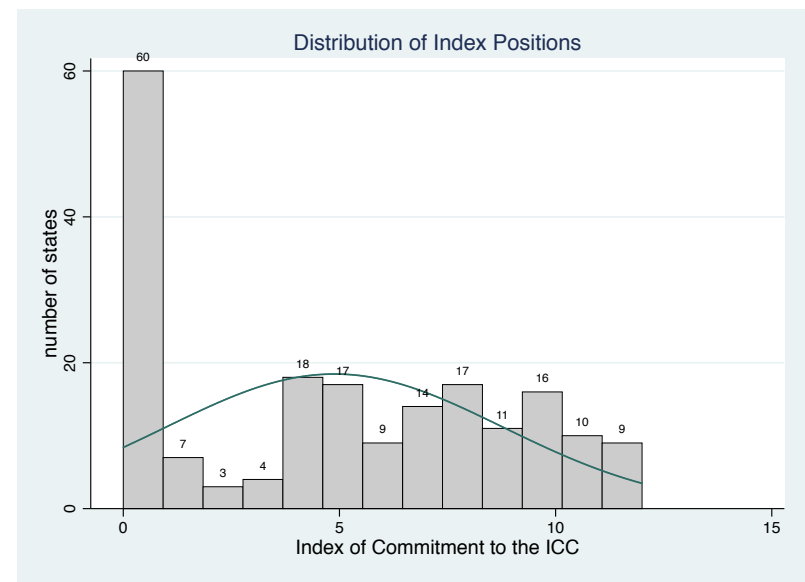

Figure 17: Streamlined Frequency Distribution of the States' Index Positions 


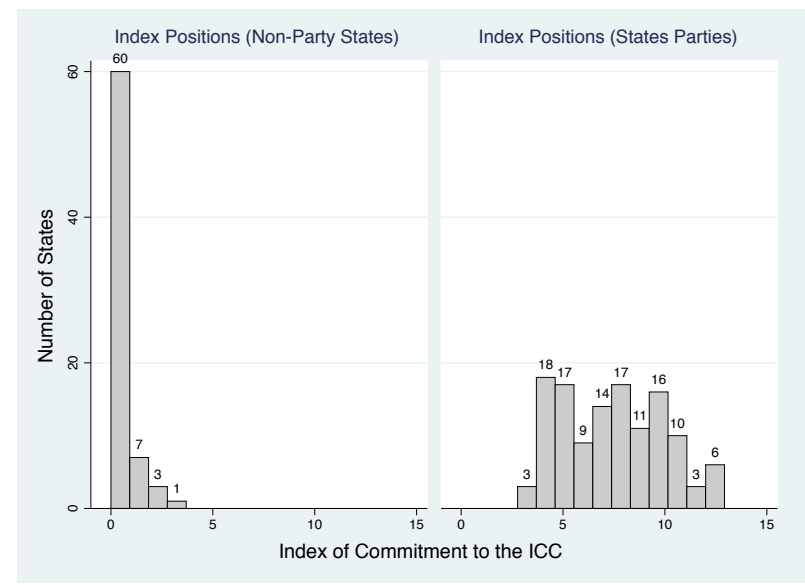

Figure 18: Frequency Distribution of the States' Index Positions by Ratification

If those states that have ratified are separated from those that have not (see Figure 18), it becomes apparent that there is a strong variation of the level of commitment to the ICC within the group of states parties. The states can be categorized into six groups (see Figure 19) giving a typology of commitment to the ICC:

Group 1 (Comprehensive Commitments) comprises those states that have reached 10.00-12.00 points and thus have bound themselves very closely to the ICC.

In Group 2 (Slightly Customized Commitment) are those that have reached 8.00-9.75 points. Although they have bound themselves very strongly to the ICC, they have slightly customized their commitments.

Group 3 (Moderately Customized Commitment) comprises those that have reached 6.00-7.75 points. Their commitments are strongly customized, and they have only reached the half of the possible index points.

Group 4 (Strongly Customized Commitment) consists of those that reached 4.00-5.75 points. They have massively customized their commitments and reached not even half of the possible index points. It is the biggest group within the states parties and the second biggest within all states. 


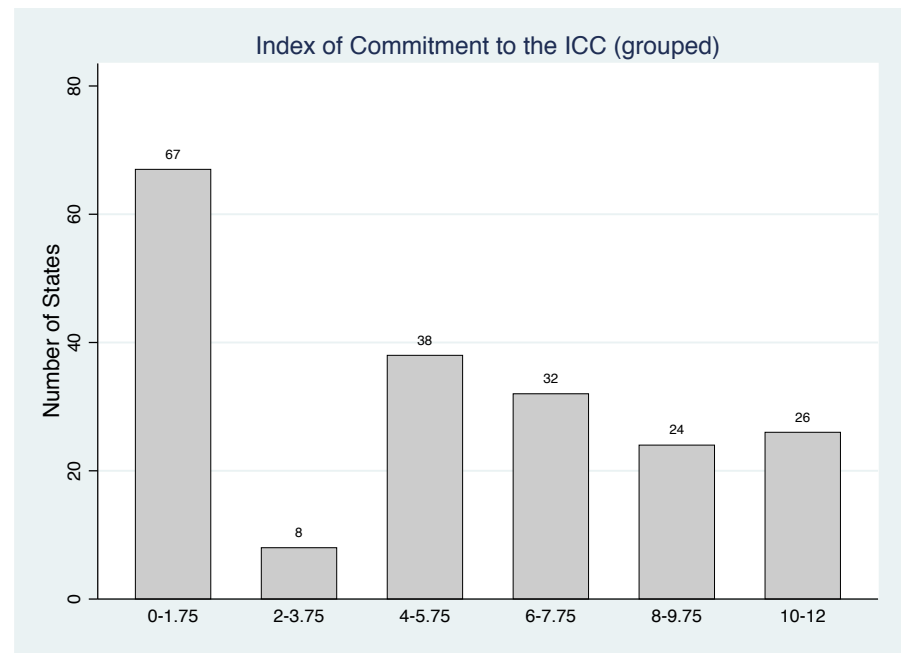

Figure 19: Grouped Frequency Distribution of the States' Index Positions

In Group 5 (Weak Commitment) are those that have reached 2.00-3.75 points. Their commitment is very weak.

Group 6 (Very Weak or No Commitment) consists of those states that have reached $0-17.5$ points and thus show hardly any or no commitment to the ICC. With 67 states, it is the biggest group within the typology of commitment to the ICC.

Thus, it can be stated that the presumptions on the levels of commitments have proven to be true: Among the states parties there are only a few states that show a very high (26 states) level of commitment, such as the Netherlands (12.0), Germany (11.5) or Belgium (10.5). Most of the states among the parties to the ICC have constraint and customized commitments, be it slightly (24 states), such as Bosnia-Herzegovina (9.5), South Korea (9.0) or the United Kingdom of Great Britain (8.0); moderately (32 states), such as the Democratic Republic of the Congo (7.5), Canada (6.5) or Portugal (6.0); or, strongly customized commitments as in the case of Burundi (5.0) and Gambia (4.5) which had both threatened to withdraw from the ICC in 2016.

As expected, among the non-party states, there are only a few which have shown rapprochement to the ICC, such as Armenia and Nicaragua with 2 points and Ukraine with 3.5 points. Most of the non-party states have no or very weak commitment (67 
states), such as Indonesia and Rwanda with 1.5 points, Russia, Turkey and Syria with 0.5 points, or China, India, Israel, Libya and the United States of America.

\subsubsection{Patterns of Commitment to the ICC}

We can observe that states often ratify the Rome Statute of the ICC, but thereafter constrain/customize their commitments. This phenomenon becomes even more apparent when comparing the status of ratification with the level of commitment to the ICC along different $\mathbb{R O} ; 117$ The whole community of the member states of the EU have ratified the Rome Statue of the ICC (see Table 18) and all of them have an index position of at least 6 points (see Table 19).

\begin{tabular}{|c|c|c|c|}
\hline \multirow[t]{2}{*}{ States Parties ICC } & \multicolumn{2}{|c|}{ States Parties EU } & \multirow[t]{2}{*}{ total } \\
\hline & & yes & \\
\hline no & 71 & 0 & 71 \\
\hline yes & 96 & 28 & 124 \\
\hline total & 167 & 28 & 195 \\
\hline
\end{tabular}

Table 18: Contingency Table - States Parties ICC \& States Parties EU

\begin{tabular}{c|cc|c} 
Index of Commitment & \multicolumn{2}{|c|}{ States Parties EU } & total \\
& no & yes & \\
\hline $10.00-12.00$ & 10 & 16 & 26 \\
$8.00-9.75$ & 15 & 9 & 24 \\
$6.00-7.75$ & 29 & 3 & 32 \\
$4.00-5.75$ & 38 & 0 & 38 \\
$2.00-3.75$ & 8 & 0 & 8 \\
$0.00-1.75$ & 67 & 0 & 67 \\
\hline total & 167 & 28 & 195
\end{tabular}

Table 19: Contingency Table - Commitment to the ICC \& States Parties EU

Likewise, all member states of Mercado Común del Sur (Mercosur) have ratified the Rome Statute of the ICC (see Table 20), however, their index points range from a comprehensive commitment to a strongly customized commitments (see Table 21).

\footnotetext{
$1 \overline{17}$ Moreover, there are some interesting constellations that would be appropriate for comparative case studies in the sense of most-similar systems designs with groups of states that shown many similar characteristics due to region, common political environment, but behave totally different in their commitment behavior towards the ICC such as Botswana, Burundi and South Africa; India and Indonesia; or Colombia, El Salvador and Nicaragua.
} 
The Index of Commitment to the ICC

\begin{tabular}{|c|c|}
\hline INDEX POINTS & Group 1 - Comprehensive Commitment (26 states) \\
\hline 12.00 & Estonia, Finland, Netherlands, Samoa, Slovenia,Trinidad and Tobago \\
\hline 11.50 & Croatia, Germany, Poland \\
\hline 11.00 & Georgia, Norway, Macedonia \\
\hline 10.50 & Austria, Belgium, Costa Rica, Cyprus, Iceland, Luxembourg, Uruguay \\
\hline 10.00 & Chile, Latvia, Lithuania, Malta, Slovakia, Spain, Switzerland \\
\hline INDEX POINTS & Group 2 - Slightly Customized Commitment (24 states) \\
\hline 9.50 & $\begin{array}{l}\text { Bulgaria, Bosnia Herzegovina, Burkina Faso, Central African Republic, Denmark, } \\
\text { Montenegro, Ireland, Serbia, Uganda }\end{array}$ \\
\hline 9.00 & Czechia, Greece, Liechtenstein, Mauritius, New Zealand, Romania, South Korea \\
\hline 8.50 & Botswana, Panama, Senegal, Sweden \\
\hline 8.00 & Albania, France, Mali, United Kingdom of Great Britain \\
\hline INDEX POINTS & "Group 3 - Moderately Customized Commitment (32 states) \\
\hline 7.50 & $\begin{array}{l}\text { Andorra, Argentina, Benin, Brazil, Democratic Republic of the Congo, Ecuador, } \\
\text { Gabon, Hungary, Japan, Mexico, Palestine, Paraguay, South Africa }\end{array}$ \\
\hline 7.00 & Bolivia, Dominican Republic, El Salvador, Honduras, San Marino \\
\hline 6.50 & Belize, Canada, Cape Verde, Guyana, Italy, Kenya, Malawi, Namibia, Tunisia \\
\hline 6.00 & Australia, Colombia, Lesotho, Portugal, Timor Leste \\
\hline INDEX POINTS & Group 4 - Strongly Customized Commitment (38 states) \\
\hline 5.75 & Ghana, Mongolia, Peru, Sierra Leone \\
\hline 5.50 & Barbados, Comoros, Cook Is., Liberia, Moldova, Philippines, Suriname, Vanuatu \\
\hline 5.25 & Jordan \\
\hline 5.00 & Bangladesh, Burundi, Cambodia, Fiji, Niger \\
\hline 4.75 & Madagascar, Tanzania, Venezuela \\
\hline 4.50 & $\begin{array}{l}\text { Afghanistan, Antigua and Barbuda, Dominica, Gambia, Grenada, Guatemala, } \\
\text { Ivory Coast, Maldives, Marshall Islands, Nauru, Nigeria, Republic of the Congo, } \\
\text { St. Kitts and Nevis, St. Lucia, Seychelles, St. Vincent and the Grenadines, Zambia }\end{array}$ \\
\hline INDEX POINTS & GROUP 5 - WEAK COMMITMENT (8 STATES) \\
\hline 3.75 & Guinea \\
\hline 3.50 & Chad, Djibouti, Tajikistan, Ukraine \\
\hline 2.00 & Armenia, Ethiopia, Nicaragua \\
\hline INDEX POINTS & "GROUP 6 - No OR VERY WEAK COMMITMENT (67 STATES) \\
\hline 1.50 & Azerbaijan, Indonesia, Rwanda \\
\hline 1.00 & Angola, Guinea-Bissau, Malaysia, Mozambique \\
\hline 0.75 & Bahamas, Jamaica \\
\hline 0.50 & $\begin{array}{l}\text { Algeria, Bahrain, Cameroon, Egypt, Eritrea, Haiti, Iran, Kuwait, Kyrgyzstan, } \\
\text { Lao PDR, Monaco, Morocco, Myanmar, Oman, Russian Federation, } \\
\text { Sao Tome and Principe, Solomon Islands, Syrian Arabic Republic, Thailand, } \\
\text { Turkey, United Arab Emirates, Uzbekistan, Yemen, Zimbabwe }\end{array}$ \\
\hline 0.00 & $\begin{array}{l}\text { Belarus, Bhutan, Brunei, China, Cuba, Equatorial Guinea, India, Iraq, Israel, } \\
\text { Kazakhstan, Kiribati, Lebanon, Libya, Mauritania, Micronesia, Nepal, North } \\
\text { Korea, Pakistan, Palau, Papua New Guinea, Qatar, Saudi Arabia, Singapore, } \\
\text { Somalia, South Sudan, Sri Lanka, Sudan, Swaziland, Togo, Tonga, Turkmenistan, } \\
\text { Tuvalu, United States of America, Vietnam }\end{array}$ \\
\hline
\end{tabular}

Table 17: Groups Within the Index of Commitment to the ICC 


\begin{tabular}{c|cc|c} 
States Parties ICC & \multicolumn{2}{|c|}{ States Parties Mercosur } & total \\
& no & yes & \\
\hline no & 71 & 0 & 71 \\
yes & 119 & 5 & 124 \\
\hline total & 190 & 5 & 195
\end{tabular}

Table 20: Contingency Table - States Parties ICC \& States Parties Mercosur

\begin{tabular}{c|cc|c} 
Index of Commitment & \multicolumn{2}{|c|}{$\begin{array}{c}\text { States Parties Mercosur } \\
\text { no }\end{array}$} & total \\
& 25 & 1 & \\
\hline $10.00-12.00$ & 24 & 0 & 26 \\
$8.00-9.75$ & 29 & 3 & 24 \\
$6.00-7.75$ & 37 & 1 & 32 \\
$4.00-5.75$ & 8 & 0 & 38 \\
$2.00-3.75$ & 67 & 0 & 8 \\
$0.00-1.75$ & 190 & 5 & 67 \\
\hline total & & & 195
\end{tabular}

Table 21: Contingency Table - Commitment to the ICC \& States Parties Mercosur

The states of the Communidad Andina de Naciones (CAN) are all parties to the ICC (see table 22, but they do have customized or even strongly customized commitments to the ICC (see table 23).

\begin{tabular}{c|cc|c} 
States Parties ICC & \multicolumn{2}{|c|}{ States Parties European CAN } & total \\
& no & yes & \\
\hline no & 71 & 0 & 71 \\
yes & 120 & 4 & 124 \\
\hline total & 191 & 4 & 195
\end{tabular}

Table 22: Contingency Table - States Parties ICC \& States Parties CAN

\begin{tabular}{c|cc|c} 
Index of Commitment & \multicolumn{2}{|c|}{ States Parties CAN } & total \\
& no & yes & \\
\hline $10.00-12.00$ & 26 & 0 & 26 \\
$8.00-9.75$ & 24 & 0 & 24 \\
$6.00-7.75$ & 29 & 3 & 32 \\
$4.00-5.75$ & 37 & 1 & 38 \\
$2.00-3.75$ & 8 & 0 & 8 \\
$0.00-1.75$ & 67 & 0 & 67 \\
\hline total & 191 & 4 & 195
\end{tabular}

Table 23: Contingency Table - Commitment to the ICC \& States Parties CAN 
From the 53 states parties to the African Union (AU), 33 states have ratified the Rome Statute (see table 24), but their level of commitment to the ICC differs strongly (see table 25].

\begin{tabular}{|c|c|c|c|}
\hline \multirow[t]{2}{*}{ States Parties ICC } & \multicolumn{2}{|c|}{ States Parties AU } & \multirow[t]{2}{*}{ total } \\
\hline & no & yes & \\
\hline no & 51 & 20 & 71 \\
\hline yes & 91 & 33 & 124 \\
\hline total & 142 & 53 & 195 \\
\hline
\end{tabular}

Table 24: Contingency Table - States Parties ICC \& States Parties AU

\begin{tabular}{c|cc|c}
\hline Index of Commitment & \multicolumn{2}{|c|}{ States Parties AU } & total \\
& no & yes & \\
\hline $10.00-12.00$ & 26 & 0 & 26 \\
$8.00-9.75$ & 17 & 7 & 24 \\
$6.00-7.75$ & 22 & 10 & 32 \\
$4.00-5.75$ & 25 & 13 & 38 \\
$2.00-3.75$ & 4 & 4 & 8 \\
$0.00-1.75$ & 48 & 19 & 67 \\
\hline total & 142 & 53 & 195
\end{tabular}

Table 25: Contingency Table - Commitment to the ICC \& States Parties AU

Only two states of the Association of Southeast Asian Nations (ASEAN) have ratified the Statute of Rome (see table 26) and both have bad rates of commitment to the ICC (see table 27).

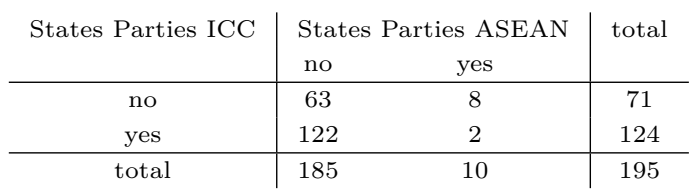

Table 26: Contingency Table - States Parties ICC \& States Parties ASEAN 


\begin{tabular}{c|cc|c} 
Index of Commitment & \multicolumn{2}{|c|}{$\begin{array}{c}\text { States Parties ASEAN } \\
\text { no }\end{array}$} & total \\
& 26 & 0 & \\
\hline $10.00-12.00$ & 24 & 0 & 26 \\
$8.00-9.75$ & 32 & 0 & 24 \\
$6.00-7.75$ & 36 & 2 & 32 \\
$4.00-5.75$ & 8 & 0 & 38 \\
$2.00-3.75$ & 59 & 8 & 87 \\
$0.00-1.75$ & 185 & 10 & 195
\end{tabular}

Table 27: Contingency Table - Commitment to the ICC \& States Parties ASEAN

This shows there is qualitative difference between the mere act of ratifying in order to become a state party and the actual extent of comprehensive commitment. The states may be put in different group based upon the extent of the commitment to the ICC. In the following chapter it will be given empirical evidence for the theoretical argument that the states' extent of commitment depends on their possibilities of solving cooperation problem of human rights law and humanitarian law. 


\section{Testing the Explanatory Power of Solving International Cooperation Problems with the ICC}

The Index of Commitment to THE ICC lends empirical evidence to the theoretical argument that states ratify the Rome Statute and become a state party to the ICC, but also constrain and customize their commitments with the intention of retaining a certain room for political maneuver. The index as a measurement for comprehensive commitment shall serve as a dependent variable. Thereby, the theoretical argument shall be tested that states' comprehensive commitment to the ICC depends on their interests in governing within the international community and their commitment to humanitarian law and human rights. The underlying consideration for this is that the ICC offers the states the possibility to reduce their monitoring costs and to increase their credibility to commitment they have already made.

A model will be developed to operationalize variables for the four main hypotheses, as well as several alternative arguments from the literature in order to make them empirically testable 5.1. Then, data set, time frame and methods of data collection and data analysis will be set out and justified 5.2. Finally, the results of the multiple linear regression and multiple logistic regression analyses testing the theoretical arguments on explaining the states' index positions and the states' decision to ratify, will be presented 5.3 . It will be shown that there is strong empirical evidence for states' commitment behavior depending on their possibilities of solving cooperation problems of international relations with the ICC.

\subsection{Model and Operationalization}

\subsubsection{Hypotheses on Solving Cooperation Problems}

From the first theoretical argument that states' commitment to the ICC depends on their willingness to participate in the governing of the international community of states and reduce the cost of monitoring humanitarian law and human rights, the following hypotheses can be derived:

Reducing Costs of Monitoring Humanitarian law \& Human Rights LaW

Hypothesis 1: The higher the level of democracy, the higher the level of commitment to the ICC.

Hypothesis 2: States that have acknowledged the $[\mathrm{CJ}$ for compulsory jurisdiction tend to have a higher level of commitment to the ICC than states that have not acknowledged the 【CJ for compulsory jurisdiction. 
The second theoretical argument that states' commitment to the ICC depend on their general attitude towards humanitarian law and human rights and the possibility of increasing their commitments to them. The following hypotheses can be derived:

Enhancing Credibility of Commitments to Humanitarian Law \& Human Rights LAW

Hypothesis 3: The higher the level of commitment to humanitarian law, the higher the level commitment to the ICC.

Hypothesis 4: The higher the level of commitment to human rights, the higher the level of commitment to the ICC.

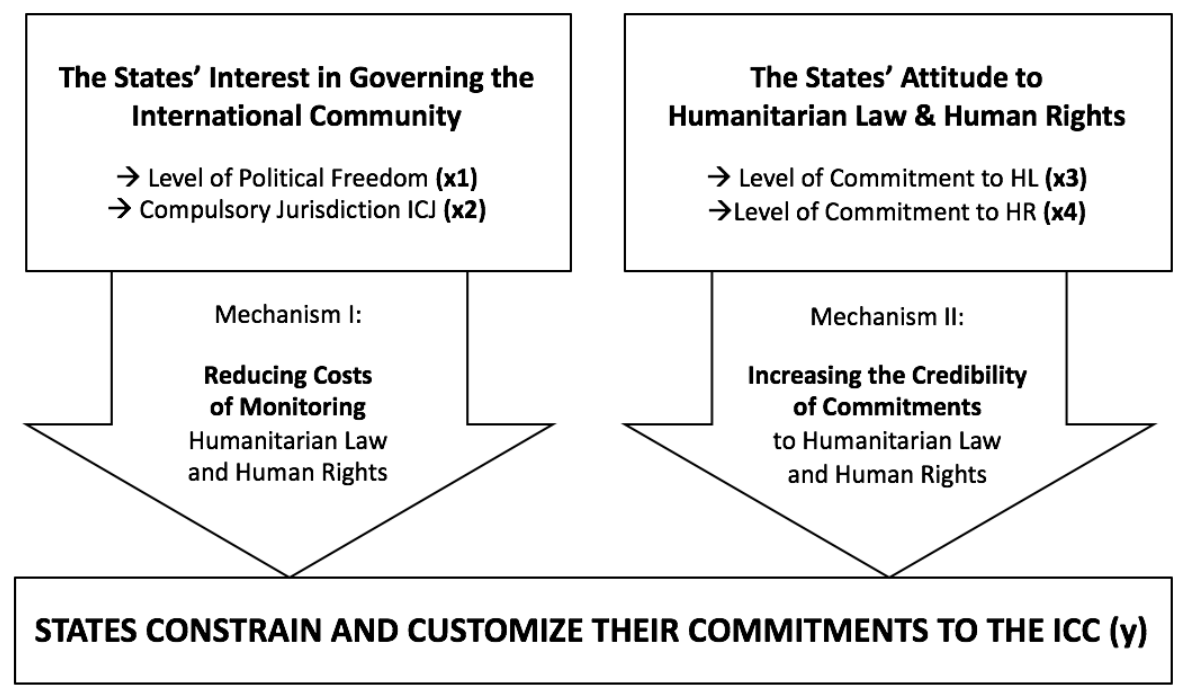

Figure 20: Causal Mechanism - Commitment and Solving Cooperation Problems

\subsubsection{Dependent Variables}

Accordingly, the dependent variable is the level of commitment to the ICC measured with the Index of Commitment to The ICC, that ranges from 0 (no or weak commitment) to 12 (comprehensive commitment). For a test of robustness and to compare the explanatory power of the theoretical argument the RATIFICATION OF THE Rome Statute is used as an additional dependent variable with the two values 0 (no ratification) and 1 (ratification). 


\subsubsection{Independent Variables}

Due to the four central hypotheses on REDUCING COSTS OF MONITORING HUMANITARIAN LAW AND HUMAN RIGHTS LAW and ENHANCING CREDIBILITY OF COMMITMENTS TO HUMANITARIAN LAW AND HUMAN RIGHTS LAW the model includes four explanatory variables: the level of democracy, subjecting to compulsory jurisdiction of the [C.] the number of ratified treaties on humanitarian law and the number of ratified treaties of human rights.

As can be seen in Figure 20, both the level of political freedom $\left(\mathrm{x}_{1}\right)$ and the recognition of compulsory jurisdiction $\left(\mathrm{x}_{2}\right)$ can be considered as indicators for the states interest in governing the international community. This is due to the fact that the ICC offers a window of opportunity to reduce the costs of monitoring humanitarian law and human rights through the creation of criminal responsibility for war crimes, crimes against humanity, genocide and the crime of aggression being able to be investigated and prosecuted at one permanent international court.

The number of ratifications of humanitarian law treaties $\left(\mathrm{x}_{3}\right)$ and of human rights law $\left(\mathrm{x}_{4}\right)$ are moreover indicators for the states' attitude towards the legalization of international peace and security. States can be expected to bind themselves to the ICC to the extent that they are already bound to humanitarian law and human rights law.

The LEVEL OF DEMOCRACY $\left(\mathrm{x}_{1}\right)$ as an independent variable is operationalized with the "Index of Freedom in the World". This measures political rights and civil liberties on an annual basis for 195 states 118 Each state is ranked in two seven-point metric scales, one for political rights and one for civil liberties, with the rating one signifying the greatest degree of freedom and seven the smallest degree of freedom. The average of the both scales, that is used in the present analysis, is called 'freedom rating'. States that are ranked between 1.0-2.5 are considered to be free, 3.0-5.0 partly free and 5.57.0 as not free. Since it is counterintuitive that one is the highest ranking and seven the lowest, the scale is reversed in the subsequent regression analyses.

The independent variable COMPULSORY JURISDICTION ICJ $\left(\mathrm{x}_{2}\right)$ specifies the states that have made declarations recognizing the jurisdiction of the [C.] as compulsory (art.36, para. 2 ICJ-Statute). This means that they have the right to bring other states to court, if those also have recognized the $\llbracket$ for compulsory jurisdiction. The corresponding data is taken from the database of the [C.] on contentious jurisdiction. 119

\footnotetext{
118 See Freedom in the World by Freedom House:

https://freedomhouse.org/report/freedom-world/freedom-world-2016 (26-09-2016). 119 See IC.J http://www.icj-cij.org/jurisdiction/?p1=5\&p2=1\&p3=3 (10-04-2017).
} 
The independent variable HUMANITARIAN LAW $\left(\mathrm{x}_{3}\right)$ counts the number of ratified treaties on humanitarian law. Therefore, 25 treaties and optional or additional protocols are checked for the ratification status of states up until 2015. Those include the Geneva Conventions I-IV, as well as its Additional Protocols I-III and the declaration on the "Acceptance of the Competence of the International Fact-Finding Commission according to article 90 of AP I". Moreover, it counts four treaties on the protection of culture and environment, 14 treaties on the use of weapons in armed conflicts and both the "Convention on the Prevention and Punishment of the Crime of Genocide" and the "Convention on the Non-Applicability of Statutory Limitations to War Crimes and Crimes against Humanity" $[20$ The data on the respective ratification status is

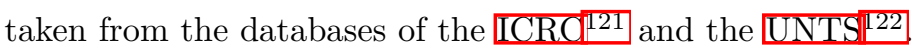

The independent variable Human Rights LaW $\left(\mathrm{x}_{4}\right)$ counts the number of ratified treaties on human rights. Therefore, 18 treaties and optional or additional protocols has been checked for the ratification status of states up to 2015. Those include the [CCPR ICESCR and several other treaties on certain aspects of human rights, such as the CAT or the CEDAW ${ }^{123}$ The data on the respective ratification status of human rights law is taken from the databases of the $\mathrm{OHCHR}^{24}$ and the UNTS| ${ }^{25}$

\subsubsection{Control Variables}

Due to the subject matter of the ICC and the interests and preferences of the states concerned, there are several alternative factors that might influence the states' comprehensiveness of commitment to the ICC that will be included in the models as control variables.

There is a control for armed conflict and peacekeeping: This is due to the consideration that we can expect states that have the most fear of investigations and prosecution to be particularly cautious or even dismissive towards the ICC ${ }^{126}$ This reflects to some extent the assumptions of approaches considering power and security

\footnotetext{
120 A list on the 25 recorded treaties on humanitarian law is to find on p. 239

121 See ICRC https://ihl-databases.icrc.org/ihl (16-09-2016).

122 See UNTS https://treaties . un.org/PAGES/Treaties . aspx?id=4\&subid=A\&clang=_en (16-09-2016).

123 A list on the 18 recorded treaties on human rights is to find on p. 240

124 See OHCHR http://indicators .ohchr.org (16-09-2016).

125 See UNTS https://treaties.un.org/PAGES/Treaties . aspx?id=4\&subid=A\&clang=_en (16-09-2016).

126 In principal, it would be obvious to control for human rights violations as well, as there is reason to assume that states with a better human rights practice tend to commit to the ICC more likely (Dutton, 2011 483). However there is a very high negative correlation with the level of political freedom (-0.718) measured with the Political Terror Scale (PTS) of 2015 (Gibney et al. 2016) so that there would be no added value including human rights violations into the regression models.
} 
as driving forces behind states behavior towards international law and international courts 127

Correspondingly, the control variable ARMED CONFLICTS $\left(\mathrm{C}_{1}\right)$ measures the sum of years of armed conflict per conflict for each state between the years 2000-2015. This shall serve as proxy for the extent of which a state is concerned in one or more armed conflicts. It is created on the basis of the Battle-Related Deaths Dataset (Melander et al. 2016) of the UCDP that collect data on armed conflicts on an annual basis to provide information on armed conflicts to a broader public.

Investigations and prosecutions could threaten states that have high military contributions to UN-peacekeeping operations. This includes several democracies like Italy, France, Germany, Great Britain or the USA. In addition to which are many nondemocratic nations that use the participation in peacekeeping operations purposefully to earn money and to procure foreign currencies, such as Ethiopia, India, Pakistan, Bangladesh, and Rwanda 128 Soldiers of UN-peacekeeping troops have been accused again and again of being involved or committing crimes themselves, such as sexual exploitation, arms trade or gold and diamonds trading, that can under certain circumstances be considered war crimes or crimes against humanity. The UN itself is not able to exercise jurisdiction and the states that deployed the troops are often unwilling or unable to prosecute peacekeepers. The ICC has no clear limit as to who should be prosecuted. In some cases the investigations could be more broadly reaching than just prosecuting higher-ranking perpetrators 129

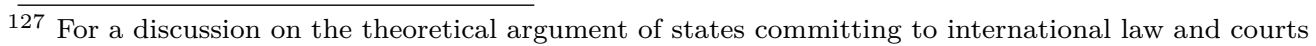
depending on increasing the own power and security, see p. 31

128 As of 2016 85,451 troops were in deployment for the 16 contemporary UN Peacekeeping operations. The contributions of the mentioned states are: Italy (1.074), France (845), Germany (379), GB (342), USA (34) and Ethiopia (8.165), India (6.752), Pakistan (6.774), Bangladesh (5.635), Rwanda (5.125), see UN Peacekeeping troops and police contributors archive: http://www.un.org/en/peacekeeping/resources/statistics/contributors.shtml (14-06-2017). In Bangladesh e.g. the government received for 1.28 billion dollar, between 2000 and 2010, as compensation for their contributions to UN peacekeeping operations. That is almost $1 \%$ of the GDP. The military salaries for UN are much higher $(\$ 1.028)$ that for the Bangladeshi military (\$193), see: http: //www.ozy.com/acumen/why-1-small-nation-plays-a-major-role-in-peacekeeping/62085 (10-05-17)

129 In an Office of the Prosecutor OTP policy paper from 2003, the problem of the impunity gap through limitations on leaders is discussed: "The strategy of focusing on those who bear the greatest responsibility for crimes within the jurisdiction of the Court will leave an impunity gap unless national authorities, the international community and the Court work together to ensure that all appropriate means for bringing other perpetrators to justice are used. In some cases the focus of an investigation by the OTP may go wider than high-ranking officers, if investigation of certain type of crimes or those officers lower down the chain of command is necessary for the whole case.", OTP policy paper, page 7, available under: https://www.icc-cpi.int/nr/ rdonlyres/1fa7c4c6-de5f-42b7-8b25-60aa962ed8b6/143594/030905_policy_paper.pdf (08-02-2017). 
The control variable of PEACEKEEPING TROops PER Mio. habitants $\left(\mathrm{C}_{2}\right)$ specifies the number of troops contributed to UN Peacekeeping operations per state in relation to the number of habitants of the states. It is created by extracting the number of contributed troops from the "troop and police contributors archive" of the United Nations peacekeeping statistic ${ }^{[30}$ and set in relation to the population in million according to the database of the CIA World Fact Book as of August 2016, that provides information on political, societal, economical and historical issues for 267 world entities

Another thinkable determinant of the comprehensiveness of commitment to the ICC could be former experiences of international criminal tribunals or amnesties. Correspondingly, there is a control for transitional justice. There is a highly controversial debate in the research literature on democratization and peace-building. Whether a political and even legal reprocessing of the past is helpful in promoting peace and democracy (Freeman, 2006; Hughes/Thakur, 2007) in in question. Some say it could further destabilize a state searching for stability and it is better to agree on amnesties during the processes of peace negotiations (Snyder/Vinjamuri, 2003, Ginsburg, 2009. Moyn, 2014) ${ }^{132}$ We can expect states that have experiences with international criminal tribunals to have a more comprehensive commitment to the ICC than states that have none, or even granted a high numbers of amnesties ${ }^{133}$ Accordingly, there are two variables created on the basis of the Transitional Justice Data Base (T.JDB) from (Olsen et al. 2010). The control variable InTERNATIONAL CRIMINAL TRIBUnALS $\left(\mathrm{C}_{3}\right)$ counts the number of international criminal tribunals a state has established and the NUMBER OF AMNESTIES $\left(\mathrm{C}_{4}\right)$ counts the number of amnesties a state has enacted between 1990-2010.

There is a control for hegemonic power due to the consideration that hegemonic power imbalances play a role in the extent of comprehensiveness of commitment to the ICC. For one thing, it could be possible that former colonial powers are more supportive towards the ICC, since they are in some instances politically and economically still tightly interconnected with their former colonies and have an interest in peace-building and peacekeeping in the former colonies. In contrast, we can expect even less powerful states, that are economically or politically highly dependent on certain hegemonic

\footnotetext{
130 See UN Peacekeeping troops and police contributors archive: http://www.un.org/en/peacekeeping/resources/statistics/contributors.shtml (02-08-2017).

131 See CIA World Fact Book: https://www.cia.gov/library/publications/the-world-factbook/fields/2119.html (24-08-17).

132 For a more detailed illustration of the several TJ-instruments see p. 85 and p. 85

133 For a legal analysis on the tension between amnesties and prosecution see e.g. Newman (2005).
} 
powers to follow the extent of comprehensiveness the latter show. The USA for example put massive pressure on the states to sign so called 'Bilateral Immunity Agreements 134 that provide for not surrendering U.S. citizens to the ICC that provide not to surrender U.S. citizens to the ICC (Kelley, 2007) 135 The control variable of Former ColOniaL Power $\left(\mathrm{C}_{5}\right)$ shows which states were a colonial power between 1800-2016. It is created by coding the data on state introductions of the CIA World Fact Bool ${ }^{136}$

The variable BIA WiTh THE USA (c6) specifies which states have negotiated a bilateral non-surrender agreement or so called 'Article 98 Agreement' with the USA, which shield citizens of the USA from a surrender to the ICC. The variable is based on coding the country reports of the $\mathrm{CICC}$ that has collected data on ratification, implementation an cooperation of the states towards the ICC ${ }^{137}$

Finally, there is a control for the influence of the legal and governmental systems with respect to the consideration that states are limited by their domestic structures. Thus, states with a common law system can be expected to have a higher level of commitments to the ICC, since they have higher incentives to implement the norms of the Rome Statute into national law. Civil law systems tend to be monistic while common law systems tend to be dualistic. States with a 'dualist system' have to translate international law into the national legal system. "Therefore, for a dualist state ratification of the Rome Statute is not enough and national implementing legislation is necessary. War crimes trials, for example, can only take place when the national legislation is enacted, unless of course such legislation already exists.' [138] States with a 'monist system' do not need to translate international law into the national legal system. The ratification of an international agreement makes it part of the national law immediately. National courts can directly apply and adjudicate the Rome Statute. Thereby,

\footnotetext{
134 Human Rights Watch has criticized some of the most striking in an open letter to the US Secretary of State of the time, Colin Powell: Croatia's accession to North Atlantic Treaty Organization (NATO) was placed in question for not signing a BIA. Niger was threatened to lose cooperative development projects. Bosnia was confronted with losing military assistance. The Philippines was offered a $\$ 30$ million for military assistance. In response, both [EU] and Mercosur made statements not to conclude such non-surrender agreements with the USA. In 2002, the EU even released a declaration with guiding principles binding EU party states and EU candidate states (Human Rights Watch, 2003).

135 For further consideration on post-colonial accusation, see p. 31 and for reflections on dependency networks and the conclusion of a BIA] with the USA see p. 62

136 See CIA World Fact Book: https://www.cia.gov/library/publications/the-world-factbook/fields/2028.html (24-04-17).

137 Country reports of the CICC http://www.iccnow.org/?mod=world (30-09-2016).

138 See Peace and Justice Initiative: http: //www.peaceandjusticeinitiative.org/implementation-resources/dualist-and-monist
} 
it should be taken into consideration that the states have a different understanding as to whether national law or international law takes precedence.

Due to this, the control variable COMMON LAW SYSTEM $\left(\mathrm{C}_{7}\right)$ is created by coding data from the CIA World Fact Book on the legal systems of the states in the world 139 as of 2016. Those systems that are pure common law systems or that combine common law with traditional law are considered to be common law systems. Moreover, with regard to the governmental systems, Goldsmith/Posner (2006) argue that states with unwritten constitutions are more likely to ratify international agreements. This is because the more democratic a state is, the more the parliament gets strengthened by international law. Thus, we could expect states with presidential systems to be less willing to ratify international agreements, since the increasing influence of international law would lead to an unintended strengthening of the parliament and a possible weakening of the president.

The control variable PARLIAMENTARY SYSTEM $\left(\mathrm{C}_{8}\right)$ is created by coding data of the CIA World Fact Book on the governmental systems of the states in the world 140 as of 2016. Those governmental systems that are pure parliamentary systems or parliamentary monarchies are considered to be parliamentary systems 141

139 See CIA World Fact Book: https://www.cia.gov/library/publications/the-world-factbook/fields/2100.html (26-09-2016).

140 See CIA World Fact Book: https://www.cia.gov/library/publications/the-world-factbook/fields/2128.html (26-09-2016).

141 An overview of the summary statistics can be found in Table 28 on p. 191 


\begin{tabular}{|c|c|c|c|c|c|}
\hline variable & $\mathbf{N}$ & mean & sd & $\min$ & $\max$ \\
\hline \multicolumn{6}{|l|}{ Dependent Variables } \\
\hline Ratification of the Rome Statute & 193 & 0.632 & 0.483 & 0 & 1 \\
\hline IndeX OF COMMITMENT TO THE ICC & 193 & 4.867 & 3.907 & 0 & 12 \\
\hline \multicolumn{6}{|l|}{ Explanatory Variables } \\
\hline Political Freedom & 193 & 4.650 & 2.021 & 1 & 7 \\
\hline COMPULSORY JURISDICTION ICJ & 193 & 0.368 & 0.483 & 0 & 1 \\
\hline HUMANITARIAN LAW TREATIES & 193 & 15.016 & 6.488 & 3 & 25 \\
\hline Geneva LaW treaties & 193 & 3.477 & 1.160 & 1 & 5 \\
\hline HUMAN RIGHTS LAW & 193 & 11.23 & 3.812 & 2 & 18 \\
\hline \multicolumn{6}{|l|}{ Control Variables } \\
\hline ARMED CONFLICTS & 193 & 3.031 & 8.036 & 0 & 75 \\
\hline PK TROOPS/MIO. HABITANT & 193 & 24.572 & 74.21 & 0 & 671 \\
\hline Number of Amnesties & 193 & 1.684 & 2.261 & 0 & 10 \\
\hline Int. Criminal Tribunal & 193 & 0.057 & 0.232 & 0 & 1 \\
\hline Former Colonial Power & 193 & 0.077 & 0.268 & 0 & 1 \\
\hline BIA WITH THE USA & 193 & 0.715 & 0.453 & 0 & 1 \\
\hline COMMON LAW SYSTEM & 193 & 0.155 & 0.363 & 0 & 1 \\
\hline PARLIAMENTARY SYSTEM & 193 & 0.492 & 0.501 & 0 & 1 \\
\hline
\end{tabular}

Table 28: Summary Statistics - Determinants for Commitment to the ICC 


\subsection{Data and Methods II - Testing Hypotheses with Regression Analyses}

\subsubsection{Case Selection and Data Set II}

A data set is created comprising information on the behavior of states towards the ICC for 193 states 142 For each of the states as cases there are 15 data points, one data point. The data is measured with cross-sectional data snapshot for 2016 as time of measurement of the Index of Commitment to the ICC. The explanatory and control variables are likewise measured as cross-sectional data dependent on both the data availability and the content-related suitability either for 2015 as lagged variables or for a certain time frame usually up to $2015{ }^{143}$

From a methodological view, it would be appropriate to measure the Index of Commitment to the ICC as well as the independent variables for every single year after the entry into force of the Rome Statute of the ICC and afterwards to examine the determinants of the index positions with a "times-series cross-sectional regression analysis". This would have allowed the examination of the development of the states' commitment to the ICC including setbacks, e.g. the withdrawal of signatures, and we could have linked such developments to certain political events. However, there is a lack of availability of annual data on the implementation of norms on complementarity and cooperation. Although the CICC continuously collects data on the implementation into national law, it is neither exhaustive nor available on an annual basis, but up to now only displayed in a continually updated version. Therefore, it would not be possible extract data on an annual basis. A "times-series cross-sectional regression analysis" would have been problematic from a theoretical view, since the amending agreements on article 8 and the crime of aggression were only adopted in 2010 .

Thus, it is a practicable and a reasonable way to use cross-sectional data for a snapshot test of the theoretical argument of states commitment behavior being dependent on their possibilities of solving cooperation problems of international relations with the ICC, such as reducing monitoring costs and enhancing the credibility of commitments to humanitarian law and human rights. The year 2016 has been chosen since this is the most recent year for which data is available.

\footnotetext{
142 While the Index of COMmitment to the ICC was measured for 195 states, the regression analyses testing explanatory factors is reduced on 193 states. Since there is a lack of data at the level of political freedom according to Freedom House for the State of Palestine and Cook Islands the two states are excluded from the regression analyses to maintain sub-sample stability.

143 A more detailed overview of variables, coding, times of measurement and sources and can be found in 'Database \& Codebook II: Determinants of Commitment (IV)]' on p.251.
} 


\subsubsection{Methods of Data Collection and Data Analysis II}

In order to test the explanatory power of the theoretical arguments for solving cooperation problems statistical methods of regression analysis will be used. This aims to draw explanatory inferences about the states' positions on the Index of Commitment to THE ICC and as robustness check in comparison to the states' ratification of the Rome Statute on their benefits of reducing cost of monitoring and enhancing the credibility of commitments to humanitarian law and human rights through establishing the ICC as international court of enforcement.

The empirical method of regression analysi: ${ }^{144}$ makes it possible not only to investigate correlations between those variables but also to examine a causal relationship that flows from the independent variables in the direction to the respective dependent variable. Gujarati $(2003,18)$ defines regression analysis as follows: "Regression Analysis is concerned with the study of the dependence of one variable, the dependent variable, on one or more other variables, the explanatory variables, with a view to estimating and/or predicting the (...) mean of average value of the former in terms of the known or fixed (...) values of the latter."

The choice of the type of regression analysis depends on the scales of the independent and dependent variables. Therefore, explaining the determinants of states' positions on the Index of Commitment to The ICC as dependent variable the method of 'Ordinary Least Squares (OLS)' as subtype of a multiple linear regression analysis is used (Gujarati, 2003). Multiple logistic regression analysis will be used to check to check robustness when examining the states' decision to ratify the Rome Statute. The method of 'multiple logistic regression analysis' will be used for a robustness check in order to examine the explanatory power of the same determinants (independent variables) on the states' decision to ratify the Rome statute of the ICC (Cox, 1958. Long/Freese, 2001) 145

\section{Explaining Positions on the Index of Commitment: Multiple Linear Regression}

The effects of the supposed determinants on the states' positions on the Index of Commitment to the ICC will be examined using an OLS as subtype of multiple linear regression analysis. The method is intended to be used for examining the influences of

\footnotetext{
144 The term of regression was originally introduced by Francis Galton. He demonstrated empirically that although tall parents tend to have tall children while short parents tend to have short children, the average height of children of parents with a certain height tend to 'regress' to the average height of the population (Galton, 1886) cited from Gujarati (2003, 17).

145 All calculations and figures explaining and illustrating the determinants of the states behavior are made with Stata IC/14.
} 
two of more independent variables on one dependent variable. The method of OLS was introduced originally by Carl Friedrich Gauss who used it for astronomical analysis of the movement of celestial bodies and geodetical measurements of the Kingdom of Hanover (Gauss, 1823). Nowadays, the OLS regression is one of the most powerful and most often used methods of regression analysis (Gujarati, 2003, 58). For this method the dependent variable has to be quantitative and continuous, while the independent variables can be either quantitative and continuous or categorial and binary. Categorical variables can be included as dummy variables 146

The multiple linear regression analysis makes it possible to express the dependent variable (position on the INDEx of COMMitment TO THE ICC) as a linear function of the four hypothesized independent variables (level of democracy, compulsory jurisdiction of the ICJ level of commitment to humanitarian law, level of commitment to human rights).

$$
\text { outcome }_{i}=\left(b_{0}+b_{1} X_{1 i}+b_{2} X_{2 i}+\ldots+b_{n} X_{n i}\right)+\text { error }
$$

Both $b_{0}$ and $b_{n}$ are the regression coefficients: $b_{n}$ quantifies the relation of outcome and predictor variable showing the direction and strength of the relationship and $b_{0}$ is the constant that shows were the respective model is located relating to the outcome (Field, 2016, 482ff.).

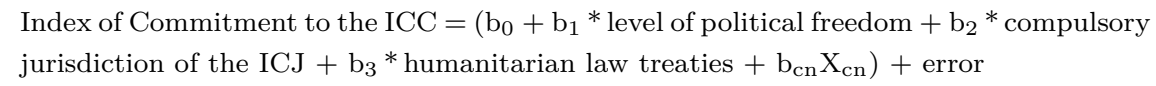

In order to control the effects of the third variables it will be tested how the main four independent variables change if the different control variables are held constant. This ensures that the effects of free floating third variables do not bias the results.

\section{Explaining Ratification of the Rome Statute: Multiple Logistic Regression Analysis}

A multiple logistic regression analysis will be used in order to compare the explanatory powers of the independent variables on the states' positions on the INDEX OF COMMITMENT TO THE ICC with those of the states' decision to ratify the Rome statute of the ICC (dependent variable).

The multiple logistic regression analysis is intended to be used for binary outcomes with two or more independent variables on one dependent variable that measures if a certain event occurs or not. The method makes it possible to examine how each independent

\footnotetext{
$1 \overline{46}$ Dummy variables indicate the presence or absence of an attribute, such as democratic or non-democratic or ratified and not ratified. Thus they only assume the two values 1 (presence of the attribute) and 0 (absence of the attribute) (see Gujarati 2003 340ff.).
} 
variable affects the probability of the event occurring. While the dependent variable is binary and given values 1 (event occurs) or 0 (event does not occur), the independent variables can be either quantitative and continuous or categorial and binary.

The method examines how changes in the values of the explanatory variables changes the odds of the dependent variable. Thus, it makes it possible to examine the influences of the explanatory variables (level of democracy, compulsory jurisdiction of the [C.] level of commitment to humanitarian law, level of commitment to human rights) on the states' decision to ratify the Rome Statute of the ICC.

Since a multiple logistic regression analysis is non-linear, the changes in the odds of the dependent variable depends on the levels of all dependent variables. Therefore, the results are much more difficult to interpret for a multiple logistic regression analysis than for a multiple linear regression analysis. No single approach is able to fully describe the relationship between the dependent and the independent variables. Thus, the key challenge is to find a convincing summary of the substantive process how changes of the independent variables lead to changes of the dependent variable (Long/Freese, 2001, 99ff.).

In the present study, the chosen method of interpretation are calculating the logit coefficients in a regression table (see e.g. table 37), the odds ratio and the probability of states ratifying the Rome Statute (see table 38). While in an OLS the coefficient tells us directly how much a unit in the dependent variable increases (or decreases) dependent on a one unit change of the independent variable, the coefficient in a logistic regression represents the natural logarithm of the odds for $\mathrm{y}=1$ changing for each unit increase (or decrease) of the independent variable. Thus, it is helpful to transform the logits to probabilities by predicting the effects of the explanatory variables while setting the others at their mean (see Mehmetoglu/Jakobsen, 2017, 167ff.).

Both for the multiple linear regression analyses and multiple regression analysis one of the basic requirements is no or small collinearity between the independent variables and thus to avoid multicollinearity. According to Frisch (1926), multicollinearity originally meant an exact linear relationship among some or even all explanatory variables in a regression model. A high collinearity leads to an increase of the standard errors, restrains the fit of the model and makes it hard to assess the importance of the individual independent variables (Field, 2016, 421f.). In the present study, the problem arises between the explanatory variables of ratified treaties of human rights and humanitarian law $(\mathrm{r}=0.71)$ and the ratified treaties of Geneva law $(\mathrm{r}=0.50)$ as shown in subsection 7.7 'Correlation Matrix - Dependent and Independent Variables'. 
What can become a statistical problem is very plausible on the theoretical level, since we can expect states that ratify a high number of human rights treaties to also ratify a high number of humanitarian law treaties. It is even more surprising that the correlation between ratified treaties of humanitarian law and human rights is not even higher. One probable explanation might be that humanitarian law has better compliance mechanisms than human rights and thus human rights are more often ratified for window dressing. We can assume that states don't have the same interest with regard to committing to human rights as they do with humanitarian law. As a result of this the two variables are measuring not the same.

The problem of multicollinearity and the associated distorted results remains. Therefore, both for the regression models explaining the states' positions on the INDEX OF Commitment то тhe ICC and for the regression models explaining the states' decision to ratify the Rome Statute robustness checks are calculated in three versions coping with cross-correlation and multicollinearity. 


\subsection{Results II - The Explanatory Power of Solving Cooperation Problems}

\subsubsection{Explaining States' Positions on the Index of Commitment}

As shown in Figure 21, the scatterplot of the states' positions on the INDEX OF COMMITMENT TO THE ICC and the level of political freedom according to Freedom House 2015 shows that there is a positive correlation $(\mathrm{r}=0.61) 147$

States with a high level of political freedom tend to have a high level of commitment to the ICC. Noticeable outliers that are not free according to Freedom House (FH), though they have high scores on the Index of Commitment to the ICC are e.g. the Central African Republic (CAF) with 9.5 IndCom points; Uganda (UGA) with 9.5; the Democratic Republic of Congo (ZAR) with 7.5; and Gabon (GAB) with 7.5 IndCom points. Moreover, one can see that among those states that have 0 index points are states of all levels of political freedom. Nevertheless, there is an overall correlation between the level of political freedom and the level of commitment to the ICC ${ }^{148}$

Figure 22 shows that states that have recognized the International Court of Justice for compulsory jurisdiction and those that have not, have a high variation in their point on the Index of Commitment to THE ICC. Nevertheless, as the regression line shows, states that have recognized the ICJ for compulsory jurisdiction tend to have a higher commitment to the ICC than states that did not $(\mathrm{r}=0.43)$.

When considering the ratified treaties of humanitarian law (see Figure 23, there is a clear positive correlation $(\mathrm{r}=0.63)$ between the number of ratified treaties of humanitarian law and the level of commitment to the ICC. Very small states, especially small island states usually have rather low rates of HR ratifications (Simmons/Danner, 2010), as can be seen here in the cases of e.g. Andorra (ADO), Marshall Islands (MHL), Samoa (WSM) or Trinidad and Tobago (TTO). However, surprising outliers here are e.g. again Uganda (UGA) with only 13 of 25 ratified Humanitarian Law (HL) treaties, the Central African Republic (CAR) with only 7, as well as Botswana (BWA) with only 8 of 25 ratified $\mathrm{HL}$ treaties.

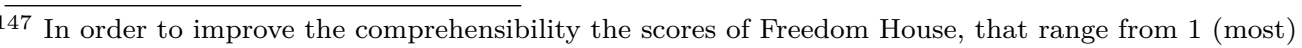
free to 7 (least free) are reversed to 7 (most free) and 1 (least free).

148 The abbreviation of the country names follows the standard of ISO 3166 Alpha 3, see ISO standards: https://www.iso.org/iso-3166-country-codes.html (20-06-2017).
} 


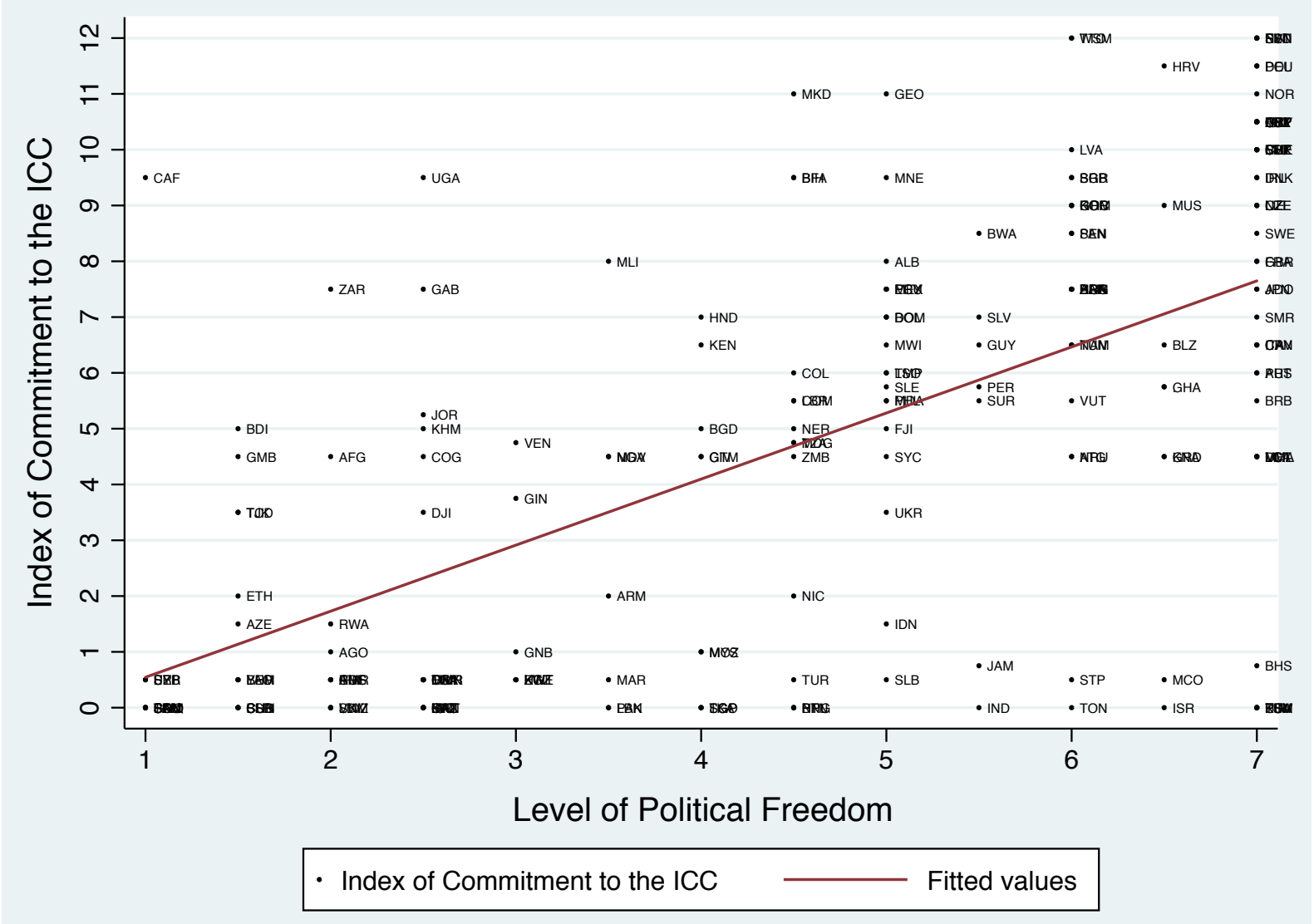

Figure 21: Scatterplot - Index and Political Freedom in the World (Reversed) 


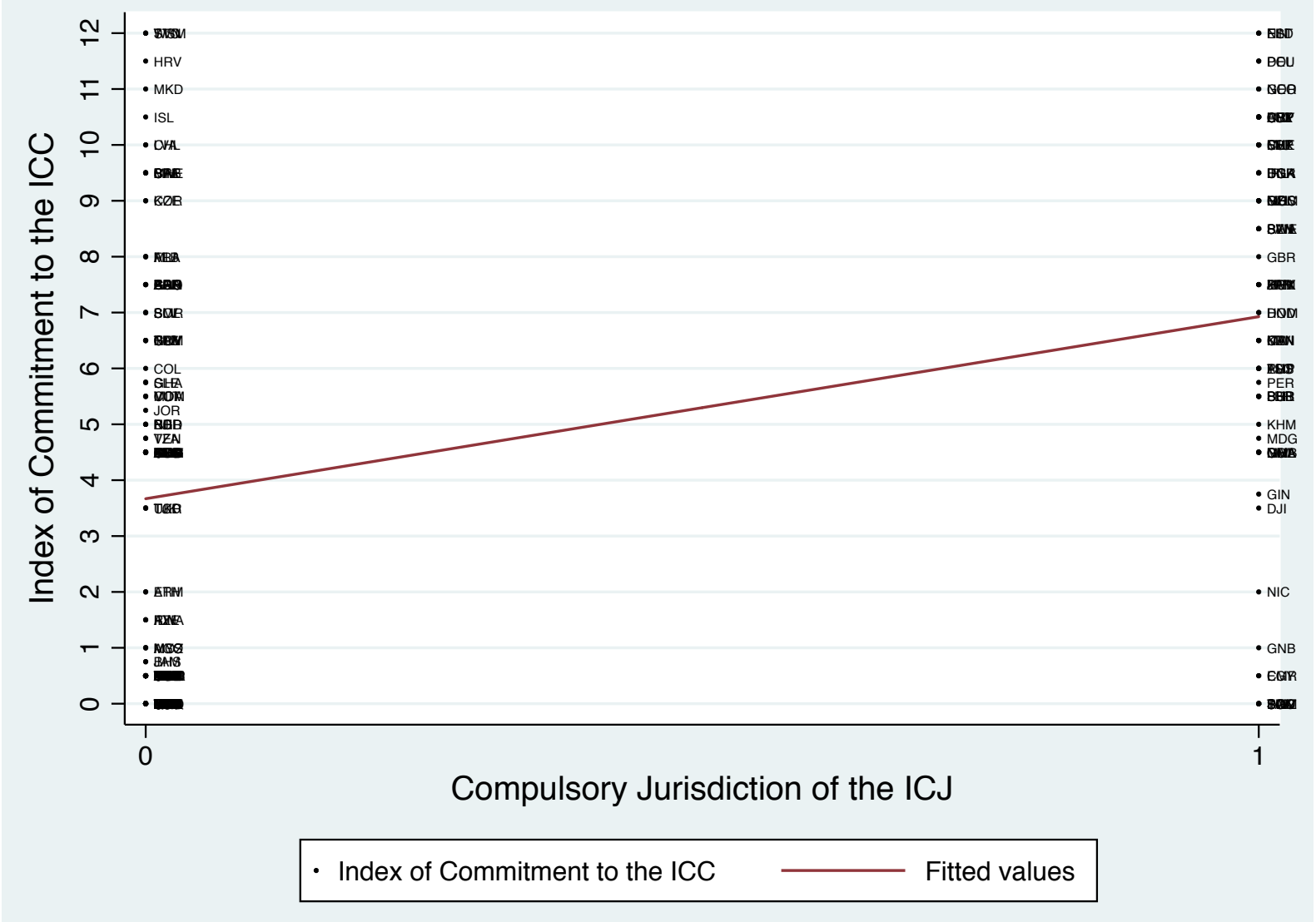

Figure 22: Scatterplot - Index and Compulsory Jurisdiction ICJ 


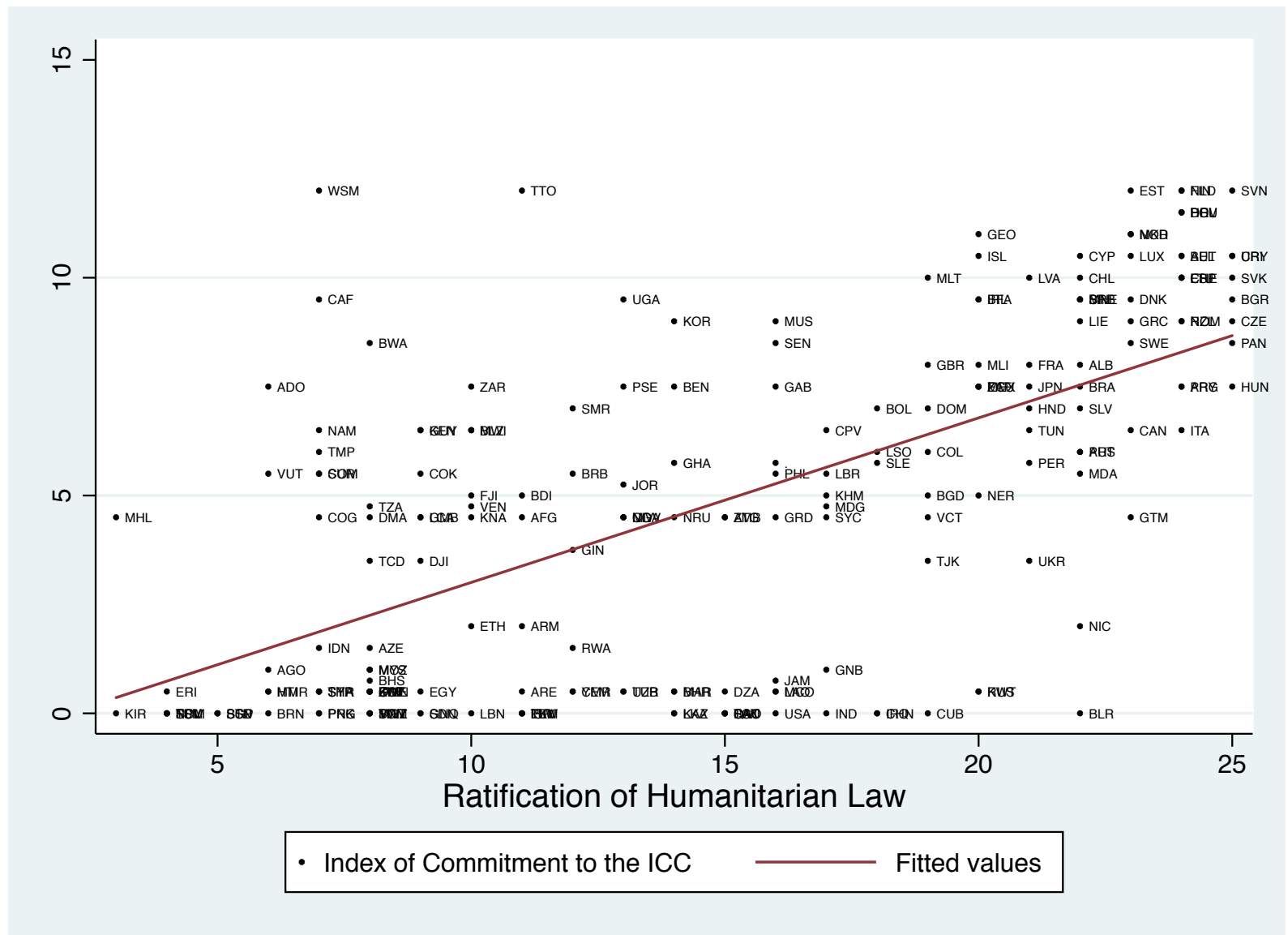

Figure 23: Scatterplot - Index and Ratified Humanitarian Law 


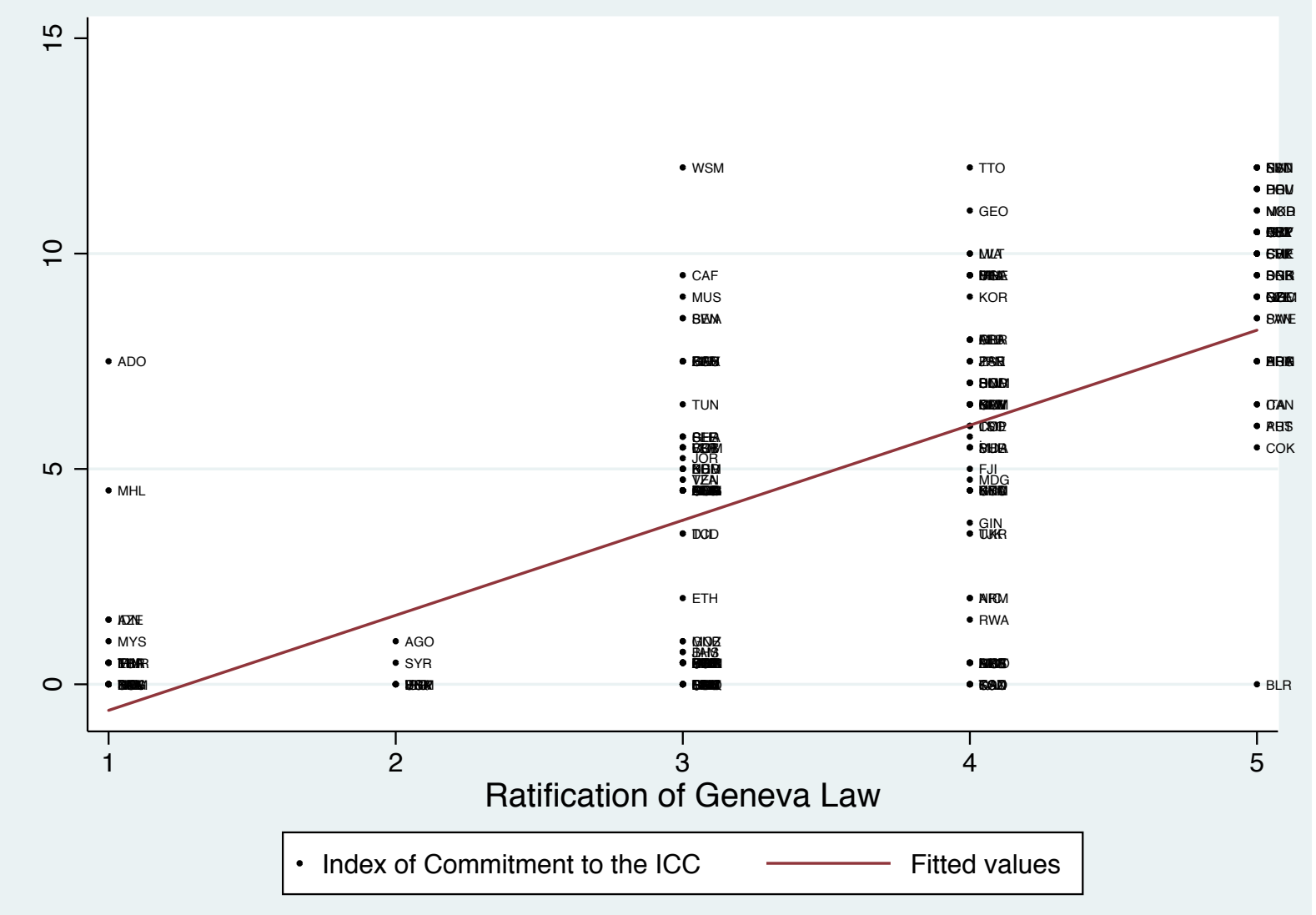

Figure 24: Scatterplot - Index and Ratified Geneva Law 


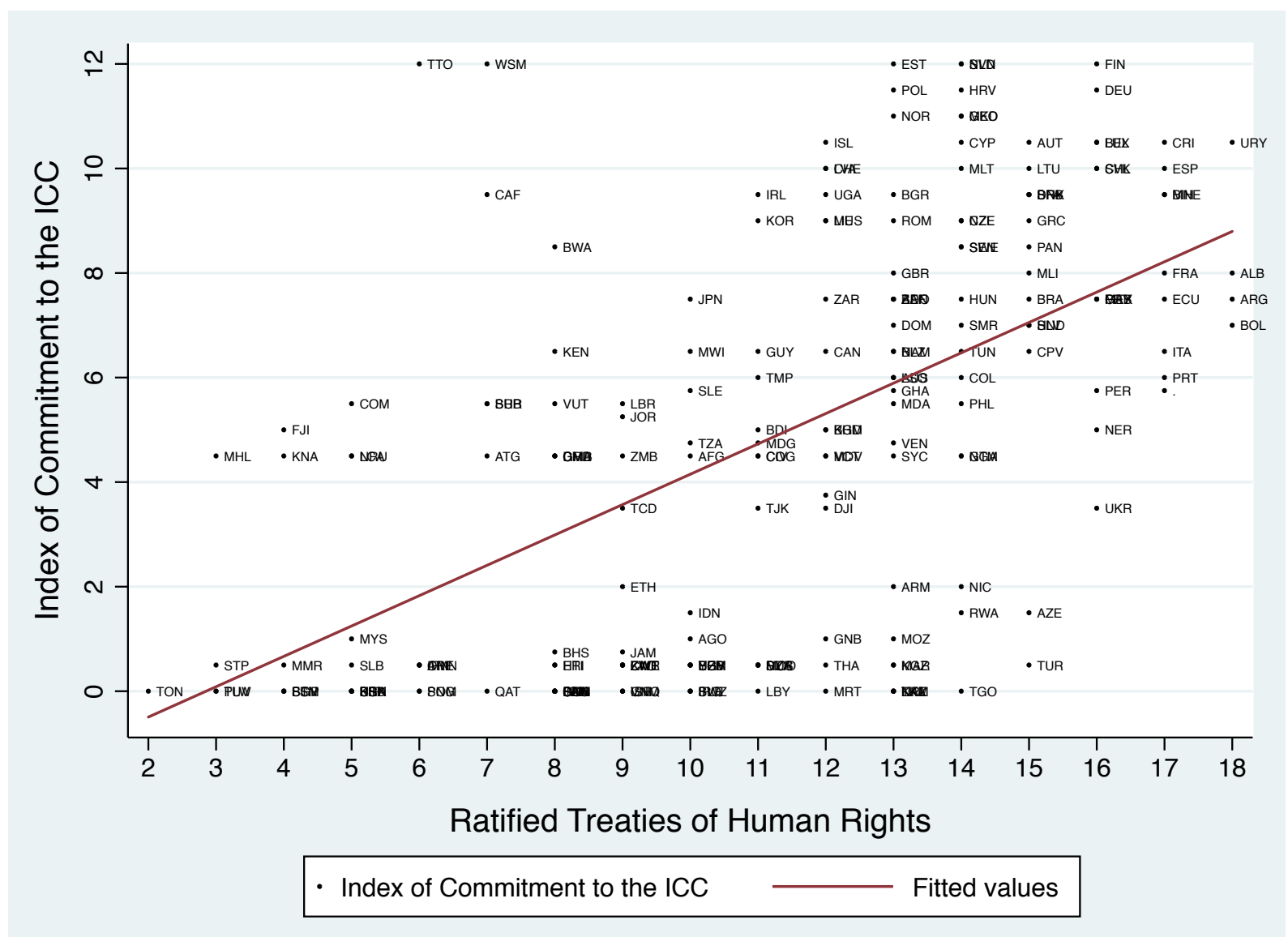

Figure 25: Scatterplot - Index and Ratified Human Rights 
Taking into account only the ratified Geneva Law (Geneva Conventions plus additional protocols), the correlations are even stronger $(\mathrm{r}=0.66)$ as shown in Figure 24. Here again, there are small (island) states as non-surprising outliers (Andorra, Marshall Islands, Samoa) and the surprising outlier Belarus (BLR) that has ratified all of the 5 treaties of Geneva Law but nevertheless has 0 points on the index. When looking at Belarus' scores on the other determinants (Freedom House $(\mathbb{E H})$ not free, not recognized the $\llbracket$. $]$ and only 10 of 25 humanitarian law treaties) it is surprising that Belarus ratified all treaties of Geneva Law although it has an IndCom score of 0.

Looking at the number of ratified treaties of human rights (see Figure 25), there is a positive correlation $(\mathrm{r}=0.57)$ with the level of commitment to the ICC. However, it should be noted that again among those states that have 0 points on the INDEX OF Commitment то тне ICC there is a high variation in the ratified human rights law. Measuring the influence of the independent variables and controlling for different third variables, the multiple linear regression analysis provides insights into the actual explanatory power of the theory of constrained and customized commitments.

Because of the high correlation between humanitarian law and human rights $(\mathrm{r}=0.703)$ and the problem of multicollinearity there would be no added value in placing both variables into one regression. Instead the regression analysis with its nine regression models will be performed in three versions in which the credibility of commitments is operationalized with the number of ratifications of HUMANITARIAN LAW (VERSION a), Geneva Law (version b) and Human Rights (version C).

In the respective regression tables, one can see the regression coefficients of the explanatory and controlling variables (in the rows) included in different regression models (in the columns). The regression coefficients show the unit increase (or decrease) of the states' position on the Index of Commitment to the ICC (as dependent variable) through each unit increase (or decrease) of the respective variable, while all the other variables in the model are held constant. The significance levels are in accordance with the convention of social sciences set at ${ }^{* * *} \mathrm{p}<0.01,{ }^{* *} \mathrm{p}<0.05,{ }^{*} \mathrm{p}<0.1$. In parentheses one can see the standard errors for the respective variables within each model, that show how strong the average deviation of the estimated parameter is, compared to the true parameter. In the last two rows one can see the adjusted coefficient of determination $R^{2}$ that measures the 'goodness of fit' by calculating the explained variation through the total variation after adjusting for the number of variables included in the model. 


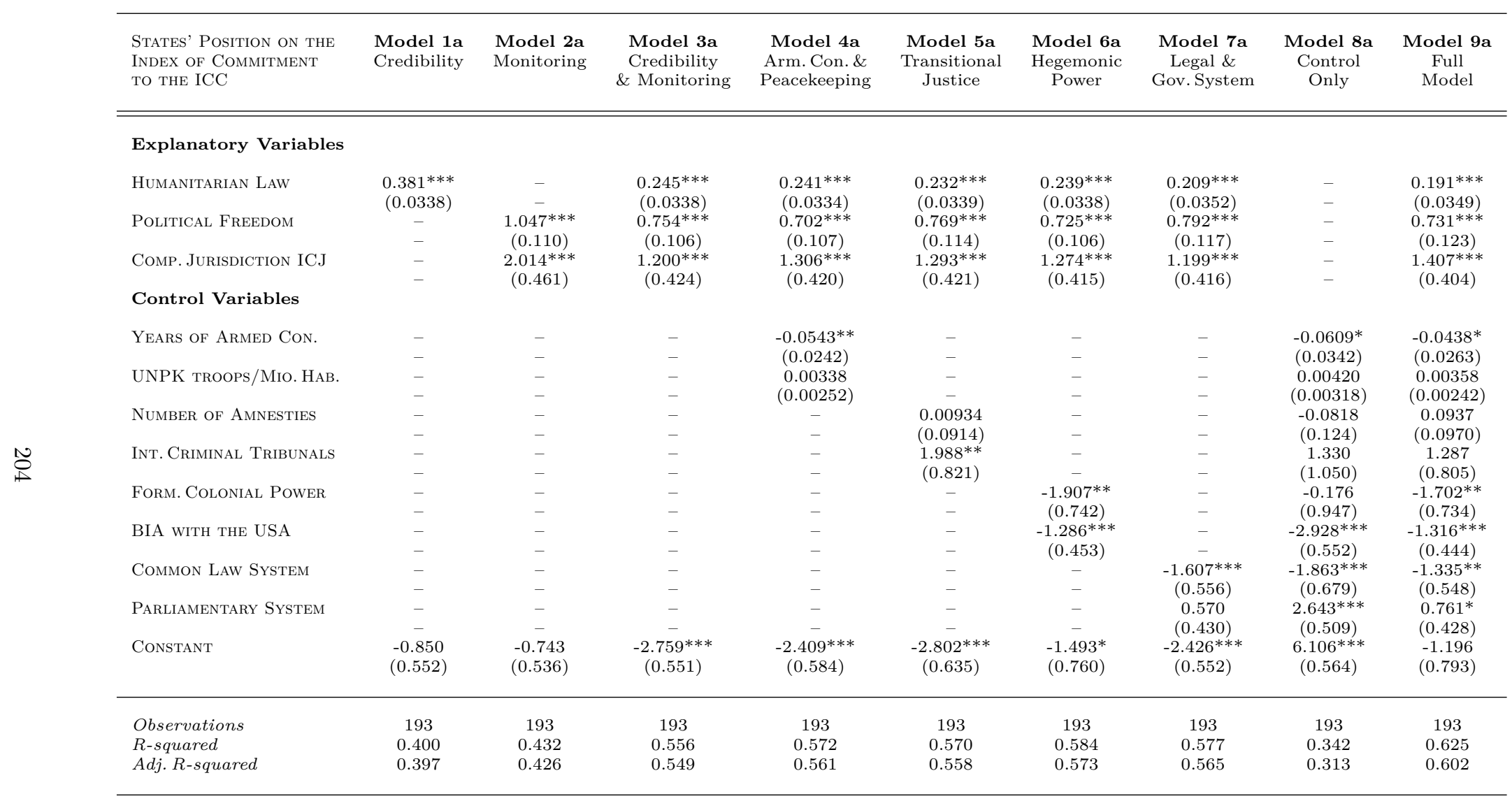

Standard errors in parentheses
$* * *$ p $<0.01, * *$ p $<0.05, * \mathrm{p}<0.1$

Table 29: Explaining States' Positions on the Index of Commitment (HL) 
Table 29 Explaining States' Positions on the Index of Commitment (HL) shows the explanatory power of the determinants of the IndEX OF Commitment to THE ICC with ratified HUMANITARIAN LAW treaties as operationalization of existing commitment to international law. Model 1a (CREDiBILITY) shows only the effect of the level of ratification of HUMANITARIAN LAW on the states' position on the INDEX OF Commitment and thus measures the explanatory power of the mechanism of solving international cooperation problems by enhancing the credibility of commitments to humanitarian law and human rights law through support of the ICC as court safeguarding those areas of international law. The regression coefficient of $0.381^{* * *}$ shows that any further ratification of one of the 25 treaties of humanitarian law leads to an increase of 0.381 of a state's position on the Index of commitment to the ICC is highly significant at ${ }^{* * *} \mathrm{p}<0.01$ signifying that there is only a chance of $1 \%$ that the null hypothesis (no influence of the number of ratified humanitarian law treaties) is true. The $R^{2}$ of 0.397 indicates that $40 \%$ of the variance in the states' index positions can be explained through the mechanism of enhancing credibility of commitments.

Analogously to that, Model 2a (Monitoring) shows the uncontrolled influences of the level of POLITICAL FREEDOM and the recognition of COMPULSORY JURISDICTION OF THE ICJ on the states' position on the InDEX of Commitment. It measures the explanatory power of the mechanism of solving international cooperation problems by reducing costs of monitoring (humanitarian law and human rights) through the establishment of the permanent court (investigating and prosecuting violations of international criminal law). Every increase of the level of political freedom leads to an increase of $1.047^{* * *}$ of the state's index position and a state that has recognized the ICJ for compulsory jurisdiction has an average increase of $2.014^{* * *}$ on the index. Here again both variables are highly significant at the $1 \%$-level, meaning there is only a chance of $1 \%$ that the null hypothesis (no influence of the level of political freedom and the recognition of the [C.J for compulsory jurisdiction) is true. The fit of the model is adjusted $R^{2}=0.426$, meaning that $43 \%$ of the variance of the states' positions on the index can be explained through the mechanism of reducing costs of monitoring humanitarian law and human rights.

If we put the three main explanatory variables together as in Model 3a (MONITORING \& CREDiBility), they remain highly significant and demonstrate $55 \%$ of the variance in the states' positions on the index. However, until this point we can't say if the fit of the model and the explanatory power of the variables actually comes from the latter, or if there are influences of third variables that are hidden in the explanatory 
variables. Accordingly, the models 4-7 control for the influences of different possible third variables.

In Model 4a (Conflict, Repression \& Peacekeeping), the explanatory variables control for the influence of experienced armed conflicts and troops contributed to UNpeacekeeping operations. Holding those potential third variables constant, the four explanatory variables still remain significant. The fit of the model still lies at $56 \%$ explained variance.

In Model 5a (Transitional Justice), there is a control for the influence of former use of amnesties and international criminal tribunals. Holding them constant the explanatory variables remain significant and the fit of the model remains at $56 \%$ explained variance.

Model 6a (Hegemonic power) controls for the influence of states being a former colonial power and having agreed as bilateral non-surrender agreement with the USA as operationalization for the influences of hegemonic power structures. While the explanatory variables are still highly significant, one can see that there is a significant negative effect on the states' position on the Index of Commitment to the ICC if a state is either a former colonial power $\left(-1.907^{* *}\right)$ or has concluded a bilateral non-surrender agreement with the USA $\left(-1.286^{* * *}\right)$. The fit of the model rises to $57 \%$.

In Model 7a (Legal and Governmental System), there is a control for the influences of the states' legal and governmental system. One can see that contrary to the assumption of the literature there is a highly significant negative effect on the states' index positions if a state has a common law system (-1.607***). Nevertheless, the explanatory variables remain highly significant and the fit of the model remains at $57 \%$.

Since some of the control variables show a significant effect in explaining the variance in the states' positions on the Index of Commitment to the ICC, they are all put into Model 8a (CONTrol VARIABles ONLY) to make them comparable to the actual explanatory power of the explanatory variables. Although their contribution in explaining the dependent variable remains high with $31 \%$ explained variance, the explanatory power of the main four variables (see Model 3) is appreciably higher at $55 \%$.

Finally in Model 9a (FUll MODEL), all explanatory and control variables are put into one, reaching a fit of $60 \%$ explained variance. The high $R^{2}$ to some extent results from cross-correlations between the variables. Although there is no multicollinearity (since there are no variables included into one model in which $\mathrm{r}$ is higher than 0.49), the remaining cross-correlations increase the $R^{2}$. However, this is de facto not a problem 
for the present study because the regression coefficients are individually significant and the study aims only to test the theoretical arguments and not to estimate exact predictors 149

The full model shows that an increase of commitment to humanitarian law leads to an increase of the states' index position of $0.191^{* * *}$, an increase of political freedom to an increase of $0.731^{* * *}$ and states that have recognized the ICJ for compulsory jurisdiction do have an average increase of $1.407^{* * *}$ on the index.

\begin{tabular}{llll}
\hline Variable & Coefficient & Min & Max \\
& & & \\
\hline Political Freedom & $0.731^{* * *}$ & 1 & 7 \\
Comp. Jurisdiction ICJ & $1.407^{* * *}$ & 0 & 1 \\
Humanitarian LaW Treaties & $0.191^{* * *}$ & 3 & 25 \\
& & & \\
\hline
\end{tabular}

Table 30: Size of Coefficients of the Three Explanatory Variables (HL)

While most of the control variables remain non-significant in the full model, there are some that still show significant influences. Experienced armed conflicts $\left(-0.0438^{*}\right)$, being a former colonial power $\left(-1.702^{* *}\right)$, having concluded a bilateral non-surrender agreement $\left(-1.316^{* * *}\right)$ and having a common law system $\left(-1.335^{* *}\right)$ show a negative influence on the states level of commitment to the ICC, while having a parliamentary governmental system shows a positive influence $\left(0.761^{*}\right)$. However, both armed conflicts and parliamentary systems are only significant at the 10\%-level, indicating that there remains a probability of $10 \%$ that the hull hypotheses is true.

If we set the size of the coefficients in relation to their minimum and maximum values that are achieved (see Table 32), it becomes apparent that the strongest effect is those of the level of POLITICAL FREEDOM, followed closely by those of the number of ratified TREATIES OF HUMANITARIAN LAW AND HUMAN RIGHTS and least the recognition of the ICJ FOR COMPULSORY JURISDICTION.

If we reproduce these nine regression models one to one, only replacing the explanatory variable of ratified humanitarian law treaties with the variable of ratified treaties of Geneva law (Geneva Conventions I-IV, API, APII, APIII, Dec under AP1) as core of humanitarian law and second proxy for states' commitment to humanitarian law, the results achieved are even stronger (see Table 31).

149 For a more detailed discussion on problems and handling of multicollinearity in different kinds of regression analyses see Gujarati (2003 370). 


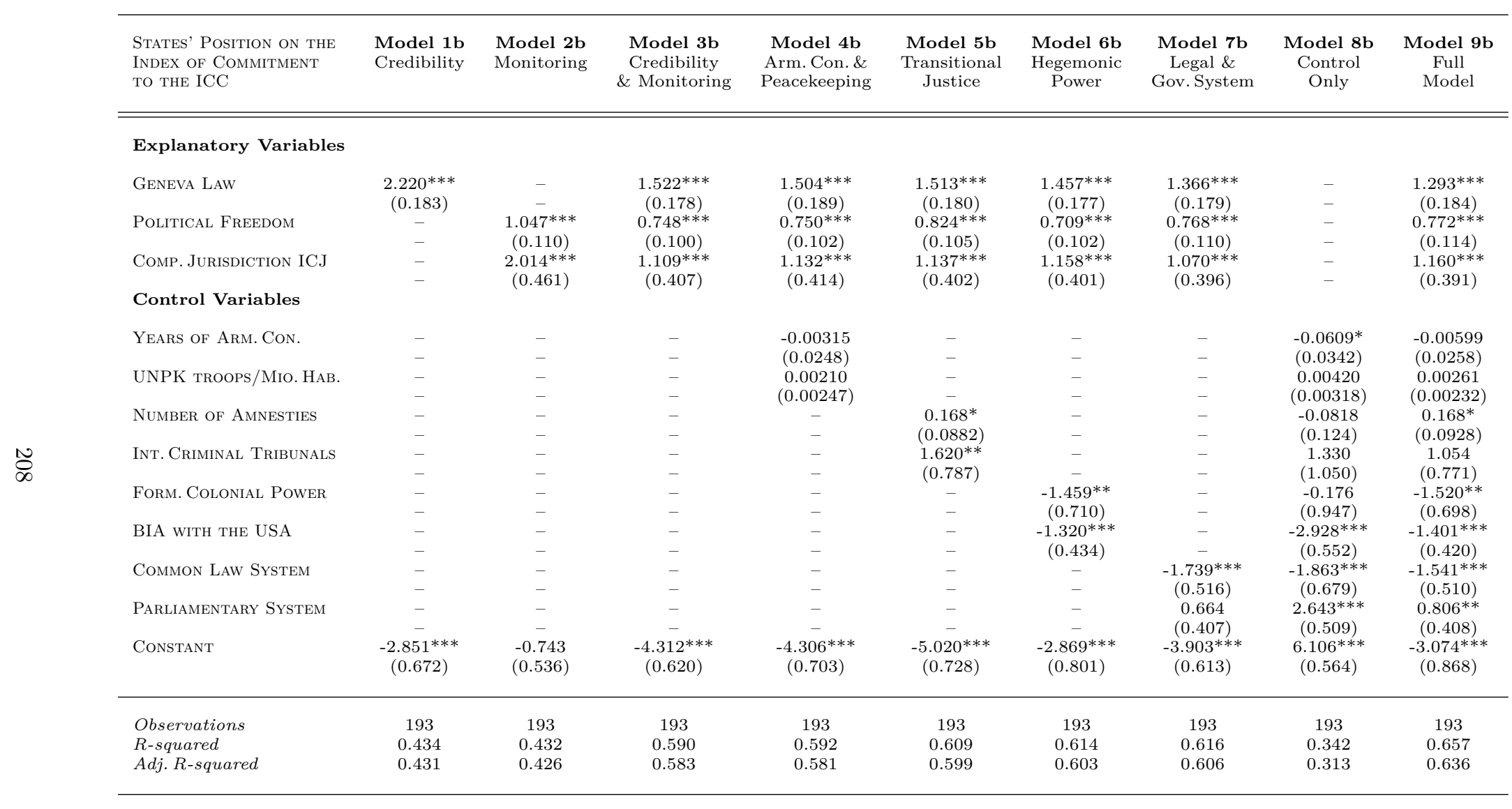

Standard errors in parentheses
$* * *$ p $<0.01, * * \mathrm{p}<0.05, * \mathrm{p}<0.1$

Table 31: Explaining States' Positions on the Index of Commitment (GL) 
We see again that the three explanatory variables are highly significant at the $1 \%$-level in all nine regression models (1b-9b). The explained variance is appreciably higher in all models that include the variable of ratified Geneva law treaties. The uncontrolled explanatory power of Geneva law lies at $43 \%$ explained variance and a regression coefficient of $2.220^{* * *}$ (Model 1b). Thus, it is higher than those of humanitarian law (Model 1a) with a regression coefficient of $0.318^{* * *}$ that were at $40 \%$ explained variance. The full model comprises all explanatory variables as well as all control variables the explained variance lies at $64 \%$. In relation to the existing minimum and maximum values, the variable of Geneva Law has the strongest effect, followed by those of the level of political freedom, the number of ratified human rights treaties. Followed last by the recognition of the ICJ for compulsory jurisdiction which demonstrates the smallest effect.

\begin{tabular}{llll}
\hline Variable & Coefficient & Min & Max \\
\hline & & & \\
\hline Political FreEdom & $0.772^{* * *}$ & 1 & 7 \\
Comp. JuRISDiCTION ICJ & $1.160^{* * *}$ & 0 & 1 \\
GENeVA LaW Treaties & $1.293^{* * *}$ & 1 & 5 \\
\hline
\end{tabular}

Table 32: Size of the Coefficients of the Three Explanatory Variables (GL)

In relation to the control variables, we see again that the factors of being a former colonial power $\left(-1.520^{* *}\right)$, having concluded a bilateral non-surrender agreement ($\left.1.401^{* * *}\right)$ and having a common law system $\left(-1.541^{* *}\right)$ have a negative influence on the states level of commitment to the ICC. A parliamentary governmental system has a positive influence $\left(0.806^{* *}\right)$ and the variable of experienced armed conflicts has lost its significance in comparison with model 8 a.

Performing the nine regression models in a third version, and thereby replacing the explanatory variable of ratified treaties of Geneva law with those of ratified treaties of human rights, a similar picture emerges (see Table 33). 


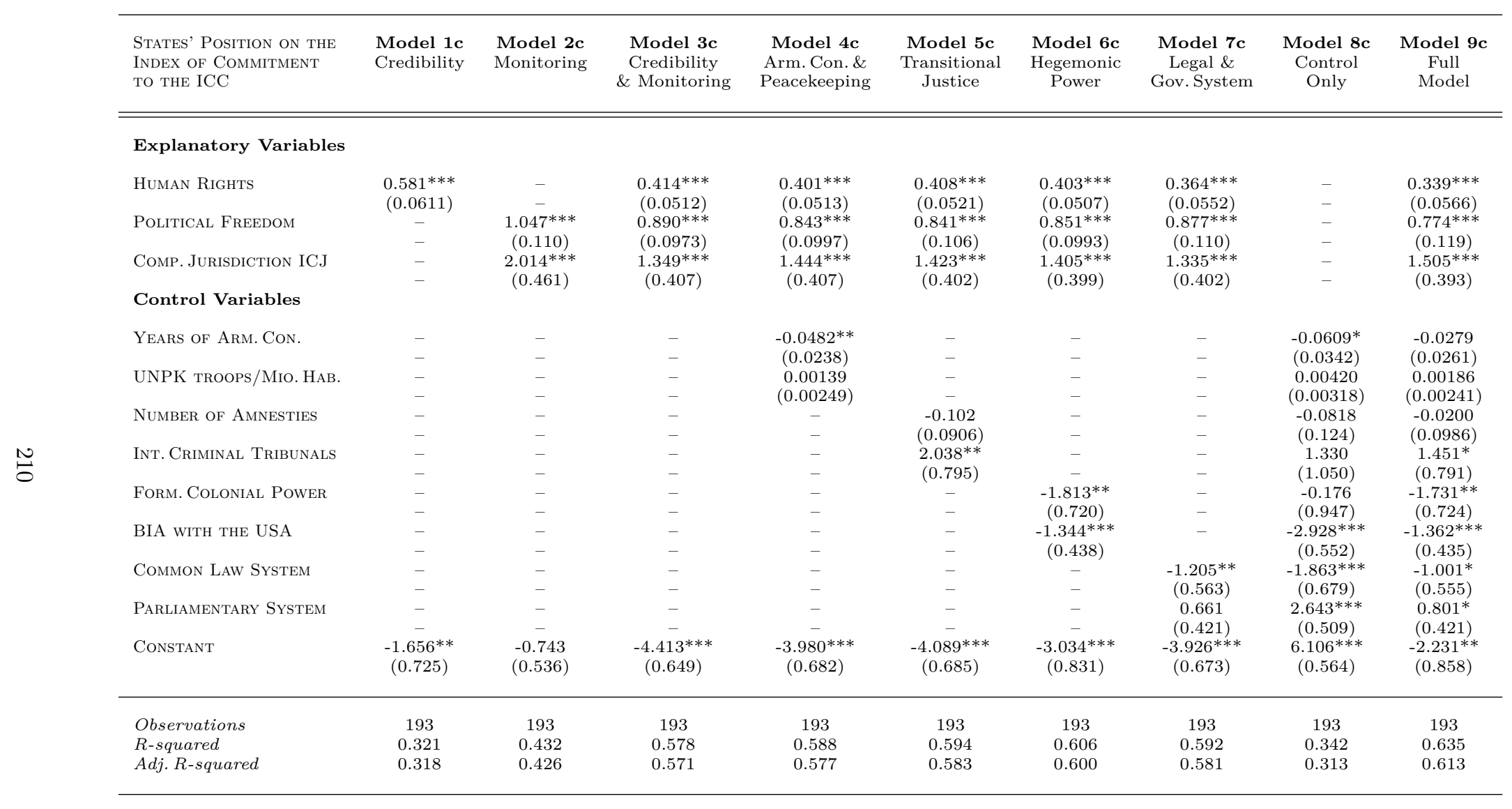

Standard errors in parentheses
$* * *$ p $<0.01, * *$ p $<0.05, * \mathrm{p}<0.1$

Table 33: Explaining States' Positions on the Index of Commitment (HR) 
The explanatory variables again remain highly significant in all nine models (1c-9c). One can see that the uncontrolled effect of ratified human rights (Model 1c) lies at $0.581^{* * *}$, meaning that any additional ratified treaty of the 18 human rights treaties leads to an average increase of 0.581 on the IndEX of Commitment to the ICC. In the full model (Model 9c) that comprises all explanatory variables as well as all control variables the explained variance lies at $61 \%$. In relation to the existing minimum and maximum values, the variable of human rights has the strongest effect, followed by those of the level of political freedom. Followed last by the recognition of the ICJ for compulsory jurisdiction which shows the smallest effect.

\begin{tabular}{llll}
\hline Variable & Coefficient & Min & Max \\
& & & \\
\hline POLITICAL FREEDOM & $0.774^{* * *}$ & 1 & 7 \\
COMP. JURISDICTION ICJ & $1.505^{* * *}$ & 0 & 1 \\
HUMAN RIGHTS LAW & $0.339^{* * *}$ & 2 & 18 \\
\hline
\end{tabular}

Table 34: Size of the Coefficients of the Three Explanatory Variables (HR)

Although the explanatory power of commitment to human rights is lower than that of commitment to humanitarian law treaties or Geneva law treaties, the overall fit of the model still reaches $61 \%$ explained variance. This might be due to the fact, that the variable of ratified human rights treaties has the lowest correlations with the variables of political freedom $(\mathrm{r}=259)$ and recognition of compulsory jurisdiction $(\mathrm{r}$ $=0.261$ ), and thus the highest added value that is included in the regression models. Nevertheless, we can state that the strongest explanatory factor for the states' position on the Index of Commitment to THE ICC is the level of ratification of Geneva law treaties. This means that it is crucial that states not only have ratified the Geneva Convention I-IV, but also the additional protocols I-III as well as the "Declaration Provided for under art.90 AP I, Acceptance of the Competence of the International Fact-Finding Commission according to art. 90 of AP I", thereby demonstrating a strong commitment to humanitarian law that is reflected in the commitment to the ICC. If we compare the explanatory power of the ratified treaties of humanitarian law, Geneva law and human rights (see Table 35), we can see that political freedom and compulsory jurisdiction of the ICJ remain constant, regardless whether the full model includes humanitarian law, Geneva law or human rights. 


\begin{tabular}{|c|c|c|c|}
\hline Variable & Coefficient & Min & Max \\
\hline \multicolumn{4}{|c|}{ Full Model 9a (Humanitarian Law) } \\
\hline Political Freedom & $0.731^{* * *}$ & 1 & 7 \\
\hline COMP. JURISDICTION ICJ & $1.407 * * *$ & 0 & 1 \\
\hline Humanitarian LaW Treaties & $0.191 * * *$ & 3 & 25 \\
\hline \multicolumn{4}{|l|}{ Full Model 9b (Geneva Law) } \\
\hline Political Freedom & $0.772^{* * *}$ & 1 & 7 \\
\hline COMP. JuRISDICTION ICJ & $1.160^{* * *}$ & 0 & 1 \\
\hline Geneva LaW Treaties & $1.293 * * *$ & 1 & 5 \\
\hline \multicolumn{4}{|c|}{ Full Model 9c (Human Rights) } \\
\hline Political Freedom & $0.774^{* * *}$ & 1 & 7 \\
\hline COMP. JuRISDICTION ICJ & $1.505^{* * *}$ & 0 & 1 \\
\hline HUMAN RIGHTS LAW & $0.339^{* * *}$ & 2 & 18 \\
\hline
\end{tabular}

Table 35: Comparison of Coefficients of Explanatory Variables in Full Models

This can be considered as strong evidence for the theoretical argument of states customizing and constraining their commitments to the ICC depending on their possibilities of solving cooperation problems of international relations, such as reducing costs of monitoring and enhancing credibility of humanitarian law and human rights. However, since the Index of Commitments to THE ICC is a scientifically constructed measurement, it is helpful to subject the explanatory power of the theoretical argument for the states' ratification of the Rome Statute of the ICC to an additional test of robustness.

\subsubsection{Explaining States' Ratification the Rome Statute}

If we look again at the four explanatory variables (political freedom, strong bond to the ICJ, commitment to humanitarian law and commitment to human rights), we can see that there is a considerable difference in values of states parties and non-party states to the ICC.

The level of political freedom is appreciably higher among those that are party to the ICC (see Figure 26). Here we can again see one aspect of the puzzle presented at the beginning of the work (see Figure 1), that those states that have the highest levels of 


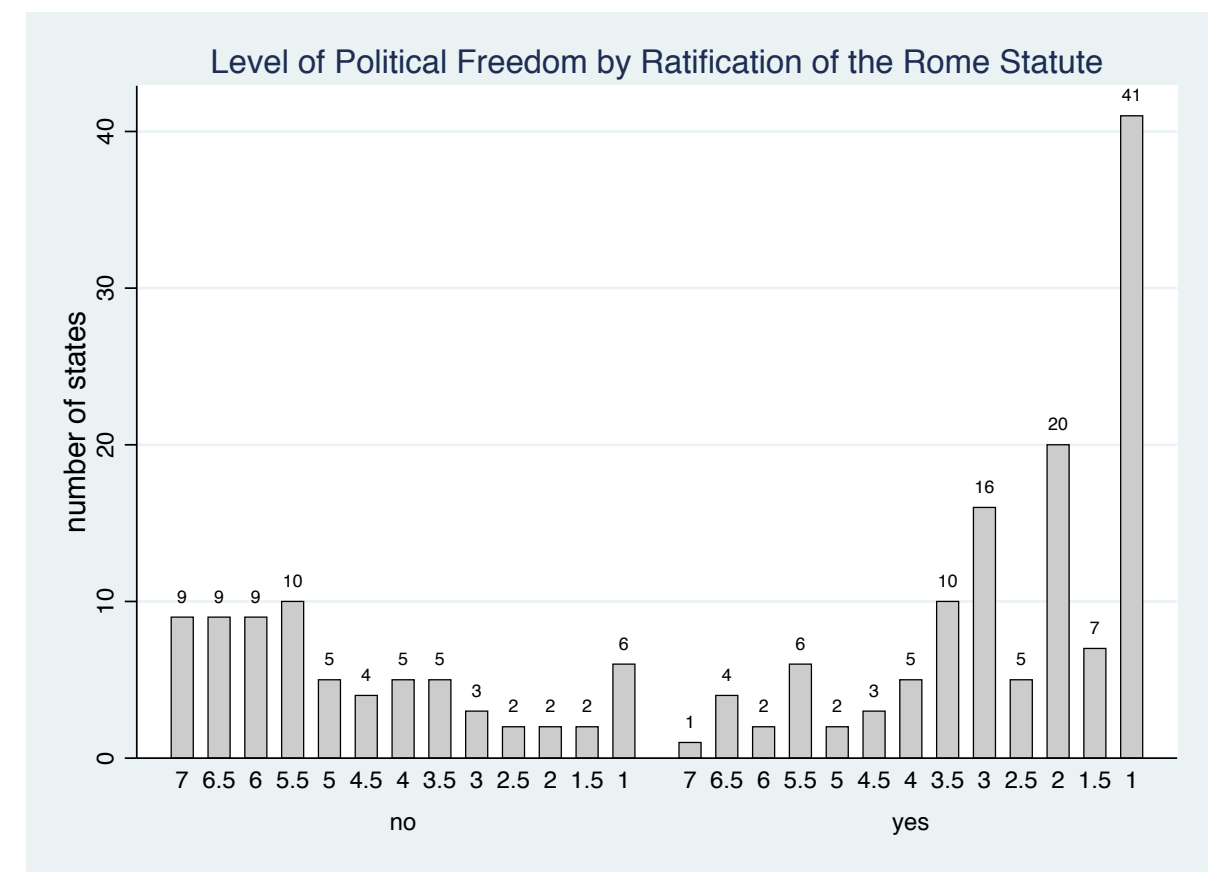

Figure 26: Level of Political Freedom by Ratification of the Rome Statute

political freedom $[150$ are among the states parties and only 12 with very high scores of political freedom - from 1 to 2.5 - are among the non-states parties, namely India, Israel, USA, Jamaica as well as some small city and island states $[51$ Moreover, there are 50 non-democratic states that nevertheless are state party to the ICC 152 Looking at the bond to the ICJ, one can see that most of the states (61 of 71) that have recognized the ICJ for compulsory jurisdiction have ratified the Rome Statute and thus are party to the ICC, nevertheless is within the group of states parties a certain balance between those that did recognize and those that did not recognize the ICJ for compulsory jurisdiction (see table 36 and figure 27).

Considering the commitment to humanitarian law and human rights, it becomes apparent that the number of states that ratified many treaties tend to be higher. Those states that have ratified a very high number of humanitarian law treaties (21 or more out of 25) are almost all states parties to the ICC (see Figure 28). Exceptional cases

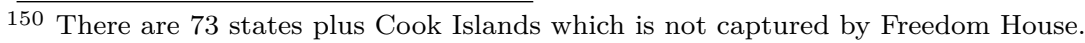

151 Bahamas, Kiribati, Micronesia, Monaco, Palau, Sao Tome and Principe, Tonga, Tuvalu.

152 For a detailed list, see the contingency table on ratification of the Rome Statute and being democracy or non-democracy on p.238.
} 


\begin{tabular}{c|cc|c} 
States Parties ICC & \multicolumn{2}{|c|}{ Comp. Jurisdiction ICJ } & total \\
& no & yes & \\
\hline no & 61 & 10 & 71 \\
yes & 63 & 61 & 124 \\
\hline total & 124 & 71 & 195
\end{tabular}

Table 36: Contingency Table - States Parties ICC \& Comp. Jurisdiction ICJ

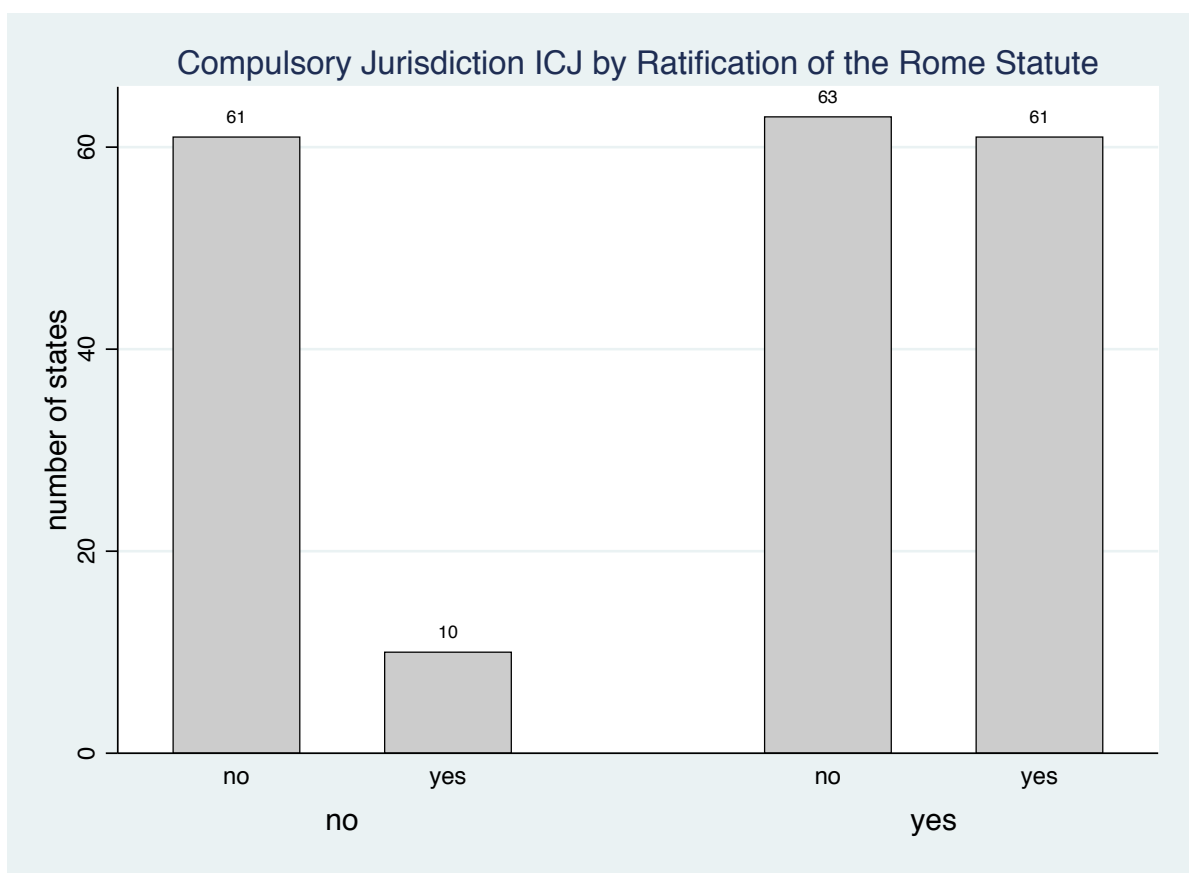

Figure 27: Compulsory Jurisdiction ICJ by Ratification of the Rome Statute 


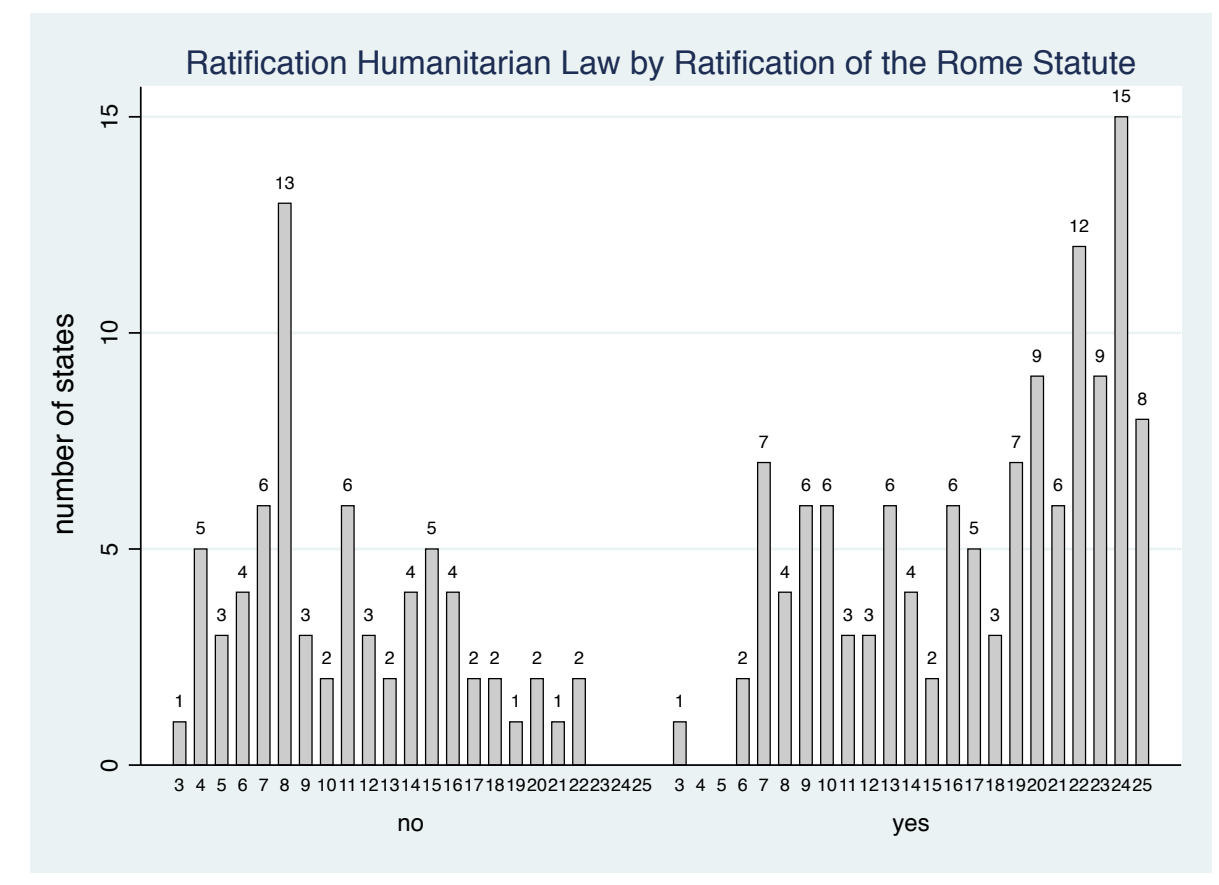

Figure 28: Commitment to Humanitarian Law by Ratification of the Rome Statute

are only Nicaragua and Belarus that ratified 22 and Ukraine that ratified 21 humanitarian law treaties ${ }^{153}$ Vice versa, the only state that has ratified only three treaties, but nevertheless is state party to the ICC is the Marshall Islands.

The same applies to the ratified treaties of Geneva Law (see 29). Belarus is the only state that has ratified all five treaties of Geneva Law, but is no state party to the ICC and, vice versa, Andorra and the Marshall Islands are the only two states that have ratified less than three treaties, but are nevertheless states parties to the ICC.

Likewise, states parties to the ICC tend to have ratified more human rights treaties with the exceptions being Fiji (4), St. Kitts and Nevis (4) as well as the Marshall Islands (3). Vice versa, non states parties tend to have ratified a much smaller number of human rights treaties with Ukraine (16), Turkey (15), Azerbaijan (14), Nicaragua (13), Rwanda (13) and Togo (13) as outliers.

In order to make reliable statements on the explanatory power of those variables for the states' decision to ratify the Rome Statute and become a party to the ICC,

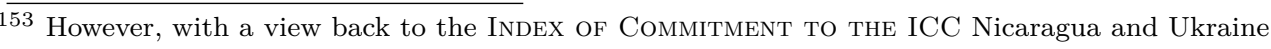
show as non-party states with 2 respectively 3 index points a certain move towards the ICC. 


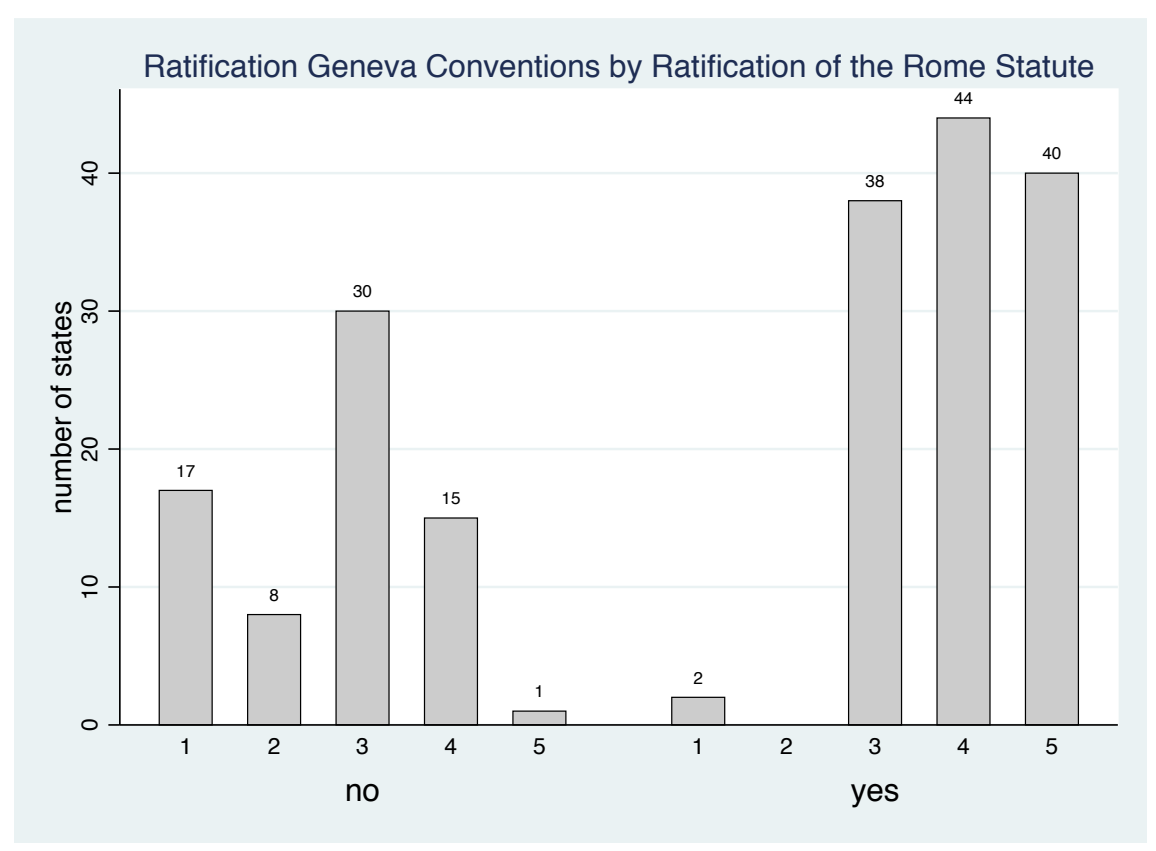

Figure 29: Commitment to Geneva Law by Ratification of the Rome Statute

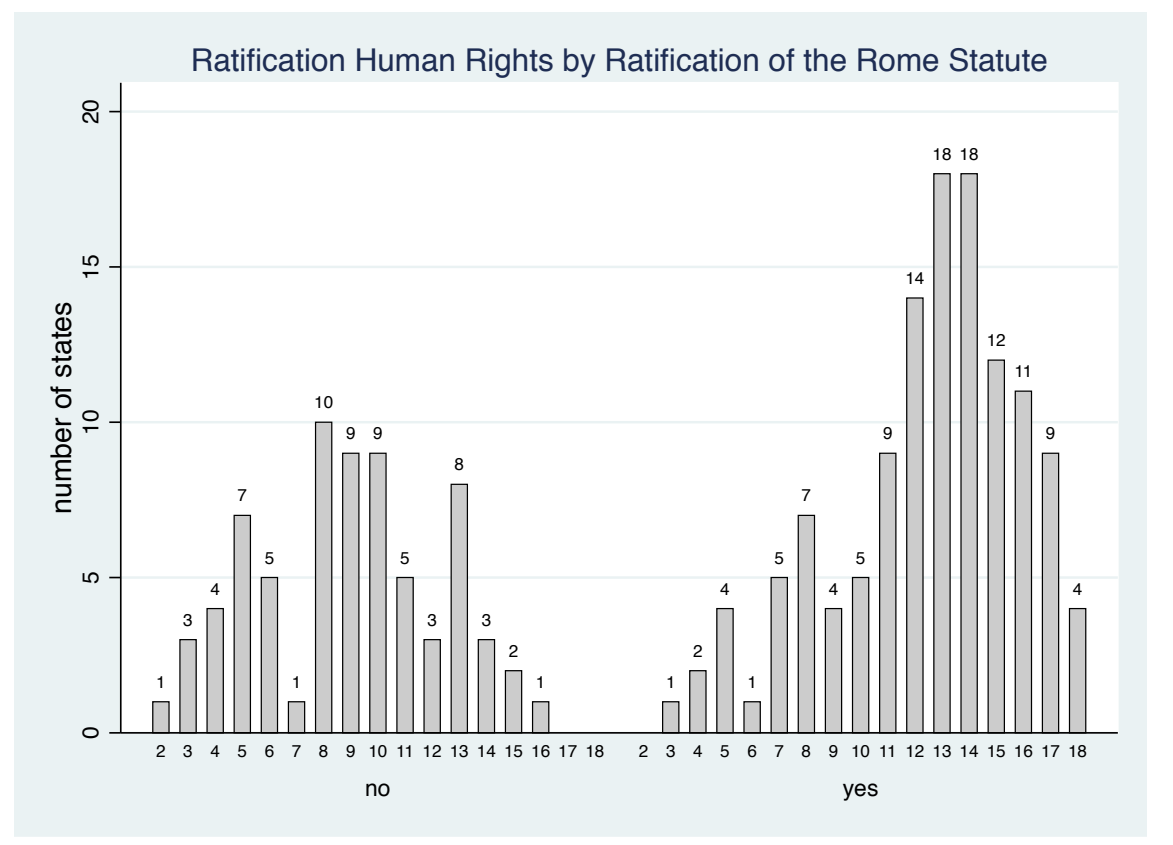

Figure 30: Commitment to Human Rights by Ratification of the Rome Statute 
we have to control again for both mutual influences and the influence of possible third variables. Accordingly, those shall be examined again in a multiple regression analysis with the ratification of the Rome Statue as new dependent variable. Since this is unlike the Index of Commitment to the ICC, not a continuous (0 to 12), but a dichotomous variable (0 vs. 1), an OLS as form of multiple linear regression analysis is not applicable.

Explaining states' decision to ratify the Rome Statute to become a state party to the ICC needs a logistic regression analysis that is able to examine the probabilities of the ratification changing from 0 to 1 in dependence of unit changes in the four explanatory variables controlled for certain third variables. One thing that is different for the interpretation of the regression results (see Table 29) is the information value of the regression coefficient. Unlike in an OLS regression, it is not possible to interpret the coefficient directly as one-unit change in the dependent variable if the independent variable increases by one unit. The 'logit coefficients' reflect how the natural logarithm of the odds for the event occurring measured by the dependent variable (ratification of the Rome Statute) changes, if the independent variable increases by one step in its scale.

Therefore, in interpreting the influence of the independent variables on the dependent variable (states' decision to ratify), it is more helpful to consider the odds ratio and to calculate probabilities of the dependent variable changing from 0 to 1 through certain changes in the values of the independent variable. The 'odds ratio' itself measures the odds of changes in the dependent variable if the independent variables changes. An odds ratio greater than 1 means that there is a positive relationship between the variables, an odds ratio less than one means that there is a negative relationship between them, and an odds ratio of exactly 1 means there is no relationship. By means of the delta-method it is possible to calculate the changes in probability for one-step changes of one certain independent variable in a model, when all the other variables are set at their mean. If the $95 \%$ confidence interval does not cross 1 the effect is significant at the 5\%-level (Mehmetoglu/Jakobsen, 2017, 169ff.).

Another difference lies in the calculation of the coefficient of determination $R^{2}$. In an OLS regression, $R^{2}$ measures the overall fit of the model. This would not be precise in a logistic regression. One alternative method is calculating Mc Fadden's pseudo $R^{2}$ that measures as intercept model the log-likelihood as total sum of squares and for the full model, and the log-likelihood as sum of squared errors for the full model (see Mehmetoglu/Jakobsen, 2017, 167). 


\begin{tabular}{|c|c|c|c|c|c|c|c|c|c|}
\hline $\begin{array}{l}\text { States' Ratification } \\
\text { OF the Rome Statute } \\
\text { TO THE ICC }\end{array}$ & $\begin{array}{c}\text { Model 10a } \\
\text { Credibility }\end{array}$ & $\begin{array}{l}\text { Model 11a } \\
\text { Monitoring }\end{array}$ & $\begin{array}{l}\text { Model 12a } \\
\text { Credibility } \\
\text { \& Monitoring }\end{array}$ & $\begin{array}{l}\text { Model 13a } \\
\text { Arm. Con. \& } \\
\text { Peacekeeping }\end{array}$ & $\begin{array}{l}\text { Model 14a } \\
\text { Transitional } \\
\text { Justice }\end{array}$ & $\begin{array}{l}\text { Model 15a } \\
\text { Hegemonic } \\
\text { Power }\end{array}$ & $\begin{array}{l}\text { Model 16a } \\
\text { Legal \& } \\
\text { Gov. System }\end{array}$ & $\begin{array}{l}\text { Model 17a } \\
\text { Control } \\
\text { Only }\end{array}$ & $\begin{array}{l}\text { Model 18a } \\
\text { Full } \\
\text { Model }\end{array}$ \\
\hline \multicolumn{10}{|l|}{ Explanatory Variables } \\
\hline HUMANITARIAN LAW & $0.186^{* * *}$ & - & $0.146^{* * *}$ & $0.154^{* * *}$ & $0.142^{* * *}$ & $0.154^{* * *}$ & $0.138^{* * *}$ & - & $0.147^{* * *}$ \\
\hline & $(0.0302)$ & $\stackrel{-}{-}$ & $(0.0357)$ & $(0.0376)$ & $(0.0365)$ & $(0.0382)$ & $(0.0371)$ & - & $(0.0411)$ \\
\hline \multirow[t]{2}{*}{ Political Freedom } & $\begin{array}{l}- \\
-\end{array}$ & $\begin{array}{c}0.611^{* * *} \\
(0.102)\end{array}$ & $\begin{array}{c}0.531^{* * *} \\
(0.106)\end{array}$ & $\begin{array}{c}0.523^{* * *} \\
(0.112)\end{array}$ & $0.531 * * *$ & $0.535^{* * *}$ & $0.557^{* * * *}$ & - & $0.558^{* * *}$ \\
\hline & - & $1.540^{* * *}$ & $1.418^{* * *}$ & $1.697^{* * *}$ & $1.415^{* * *}$ & $1.479^{* * *}$ & $1.414^{* * *}$ & - & $1.714^{* * *}$ \\
\hline Control Variables & - & $(0.434)$ & $(0.472)$ & $(0.510)$ & $(0.473)$ & $(0.483)$ & $(0.476)$ & - & $(0.525)$ \\
\hline \multirow[t]{2}{*}{ Years of Arm. Con. } & - & - & - & $-0.0591 * *$ & - & - & - & $-0.0697^{* *}$ & $-0.0583^{*}$ \\
\hline & - & - & - & $(0.0255)$ & - & - & - & $(0.0354)$ & $(0.0300)$ \\
\hline \multirow[t]{2}{*}{ UNPK troops/Mio. НAB. } & - & - & - & 0.00566 & - & - & - & 0.00470 & 0.00572 \\
\hline & - & - & - & $(0.00360)$ & - & - & - & $(0.00334)$ & $(0.00363)$ \\
\hline \multirow[t]{2}{*}{ Number of Amnesties } & - & - & - & - & -0.00447 & - & - & 0.0170 & 0.112 \\
\hline & - & - & - & - & $(0.0938)$ & - & - & $(0.0910)$ & $(0.114)$ \\
\hline \multirow[t]{2}{*}{ Int. Criminal Tribunals } & - & - & - & - & 0.760 & - & - & 0.392 & 0.204 \\
\hline & - & - & - & - & $(0.943)$ & - & - & $(0.869)$ & $(0.976)$ \\
\hline \multirow[t]{2}{*}{ FORM COLONIAL POWER } & - & - & - & - & - & $-2.026^{*}$ & - & 0.0392 & -1.647 \\
\hline & - & - & - & - & - & $(1.096)$ & - & $(0.874)$ & $(1.291)$ \\
\hline \multirow[t]{2}{*}{ BIA WITH THE USA } & - & - & - & - & - & $-1.080^{* *}$ & - & $-1.605^{* * *}$ & $-1.107^{*}$ \\
\hline & - & - & - & - & - & $(0.539)$ & - & $(0.469)$ & $(0.569)$ \\
\hline \multirow[t]{2}{*}{ Common LaW System } & - & - & - & - & - & - & -0.504 & -0.317 & -0.269 \\
\hline & - & - & - & - & - & - & $(0.548)$ & $(0.497)$ & $(0.585)$ \\
\hline \multirow[t]{2}{*}{ Parliamentary System } & - & - & - & - & - & - & 0.0694 & $1.212^{* * *}$ & 0.240 \\
\hline & - & - & - & - & - & - & $(0.432)$ & $(0.370)$ & $(0.474)$ \\
\hline Constant & $\begin{array}{c}-2.077^{* * *} \\
(0.433)\end{array}$ & $\begin{array}{c}-2.590^{* * *} \\
(0.484)\end{array}$ & $\begin{array}{c}-4.160^{* * *} \\
(0.683)\end{array}$ & $\begin{array}{c}-4.219^{* * *} \\
(0.747)\end{array}$ & $\begin{array}{c}-4.141^{* * *} \\
(0.732)\end{array}$ & $\begin{array}{c}-3.336^{* * *} \\
(0.868)\end{array}$ & $\begin{array}{c}-4.106^{* * *} \\
(0.688)\end{array}$ & $\begin{array}{c}1.346^{* * * *} \\
(0.458)\end{array}$ & $\begin{array}{c}-3.588^{* * *} * \\
(0.965)\end{array}$ \\
\hline Observations & 193 & 193 & 193 & 193 & 193 & 193 & 193 & 193 & 193 \\
\hline Pseudo R-squared & 0.197 & 0.288 & 0.361 & 0.401 & 0.364 & 0.390 & 0.364 & 0.181 & 0.429 \\
\hline Log Likelihood & -101.977 & -90.463 & -81.148 & -76.096 & -80.796 & -77.481 & -80.723 & -103.926 & -72.458 \\
\hline
\end{tabular}

Standard errors in parentheses
$* * *$ p $<0.01, * *$ p $<0.05, * \mathrm{p}<0.1$

Table 37: Explaining States' Ratification of the Rome Statute (HL) 
The models in the multiple logistic regression explaining the states' decisions to ratify the Rome Statute are build up analogously to those of the multiple linear regression explaining states' positions on on the Index of Commitment to the ICC 154 The explanatory variables Political Freedom, Comp. Jurisdiction ICJ and HuMANITARIAN LAW are again significant throughout all models (10a-18a). In Model 18a (FULL MODEL) the three explanatory variables are significant and reaches $43 \%$ explained variance. When comparing the exact risk and protective factors of the variables, it is helpful to look at their odds ratios and probabilities.

As shown in table 38 in the full model, all the explanatory variables are a risk factor for and thus encourage the ratification of the Rome Statute. An one step change at the level of Political Freedom increases the probability of ratification by $74.7 \%$ per unit increase. States that have recognized Comp. JuRisDiCTION ICJ have a $454.8 \%$ probability of ratifying the Rome Statute and with each ratified treaty of HumANITARIAN LAW, the probability of ratification increase by $15.8 \%$.

Looking at the significance of the control variables compared to the OLS that explains the states' index positions, it is especially noticeable that being a former colonial power has no significant explanatory power at all. While being a former colonial power has a significant negative effect on the states positions on the INDEX OF Commitment to ICC, all but Turkey, the USA and Russia are party to the ICC. Having agreed to a BIA with the USA is a protective factor which decreases the probability of ratification by $67 \%$.

If the variable of ratified humanitarian law treaties is replaced by the variable of ratified Geneva law (see 39), we can observe the same effect as in the OLS explaining the states' index positions. The explained variances increase in all models concerned. It goes up to $47 \%$ explained variance in the full model. The three explanatory variables are highly significant throughout all models (10b-18b).

154 See on p.204 for the version with ratified humanitarian law treaties and on p.208 for the version with the ratified Geneva law. 


\begin{tabular}{|c|c|c|c|c|c|}
\hline Variable & Coefficient $b$ & Odds Ratio & $\begin{array}{l}\text { \% Change in Odds } \\
\text { for Unit Change in } x\end{array}$ & Min. & Max. \\
\hline \multicolumn{6}{|l|}{ Explanatory Variables } \\
\hline HUMANITARIAN LAW & $0.147 * * *$ & $1.584^{* * *}$ & $15.8 \%$ & 3 & 25 \\
\hline Political Freedom & $0.558 * * *$ & $1.747 * * *$ & $74.7 \%$ & 1 & 7 \\
\hline Comp. Jurisdiction ICJ & $1.714^{* * *}$ & $5.548^{* * *}$ & $454.8 \%$ & 0 & 1 \\
\hline \multicolumn{6}{|l|}{ Control Variables } \\
\hline Years of Armed Conflicts & $-0.058^{*}$ & $0.943^{*}$ & $-5.7 \%$ & 0 & 75 \\
\hline UNPK TROOPS/Mio. НAB. & 0.006 & 1.006 & - & 0 & 671 \\
\hline Number of Amnesties & 0.112 & 1.118 & - & 0 & 10 \\
\hline Int. Criminal Tribunal & 0.204 & 1.227 & - & 0 & 1 \\
\hline Form. Colonial Power & -1.647 & 0.193 & - & 0 & 1 \\
\hline BIA WITH THE USA & $-1.107^{*}$ & $0.330^{*}$ & $-67.0 \%$ & 0 & 1 \\
\hline Common LaW System & -0.269 & 0.764 & - & 0 & 1 \\
\hline Parliamentary System & 0.240 & 1.271 & - & 0 & 1 \\
\hline
\end{tabular}

Table 38: Probabilities for Ratification of the Rome Statute in Full Model (HL) 


\begin{tabular}{|c|c|c|c|c|c|c|c|c|c|}
\hline $\begin{array}{l}\text { States' Ratification } \\
\text { OF the Rome Statute } \\
\text { TO the ICC }\end{array}$ & $\begin{array}{l}\text { Model 10b } \\
\text { Credibility }\end{array}$ & $\begin{array}{l}\text { Model 11b } \\
\text { Monitoring }\end{array}$ & $\begin{array}{l}\text { Model 12b } \\
\text { Credibility } \\
\text { \& Monitoring }\end{array}$ & $\begin{array}{l}\text { Model 13b } \\
\text { Arm. Con. \& } \\
\text { Peacekeeping }\end{array}$ & $\begin{array}{l}\text { Model 14b } \\
\text { Transitional } \\
\text { Justice }\end{array}$ & $\begin{array}{l}\text { Model 15b } \\
\text { Hegemonic } \\
\text { Power }\end{array}$ & $\begin{array}{l}\text { Model 16b } \\
\text { Legal \& } \\
\text { Gov. System }\end{array}$ & $\begin{array}{l}\text { Model 17b } \\
\text { Control } \\
\text { Only }\end{array}$ & $\begin{array}{l}\text { Model 18b } \\
\text { Full } \\
\text { Model }\end{array}$ \\
\hline \multicolumn{10}{|l|}{ Explanatory Variables } \\
\hline Geneva LaW & $\begin{array}{c}1.326^{* * *} \\
(0.215)\end{array}$ & - & $\begin{array}{c}1.158^{* * *} \\
(0.235)\end{array}$ & $\begin{array}{c}1.107^{* * *} \\
(0.244)\end{array}$ & $\begin{array}{c}1.187^{* * *} \\
(0.242)\end{array}$ & $\begin{array}{c}1.163^{* * *} \\
(0.240)\end{array}$ & $\begin{array}{c}1.120^{* * *} \\
(0.237)\end{array}$ & - & $\begin{array}{c}1.111^{* * *} \\
(0.257)\end{array}$ \\
\hline \multirow[t]{2}{*}{ Political Freedom } & - & $0.611^{* * *}$ & $0.567^{* * *}$ & $0.581^{* * *}$ & $0.619^{* * *}$ & $0.551^{* * *}$ & $0.579 * * *$ & - & $0.612^{* * *}$ \\
\hline & - & $(0.102)$ & $(0.113)$ & $(0.119)$ & $(0.123)$ & $(0.117)$ & $(0.126)$ & - & $(0.142)$ \\
\hline COMP. JURISDICTION ICJ & - & $1.540^{* * *}$ & $1.398^{* * *}$ & $1.500^{* * *}$ & $1.337^{* * *}$ & $1.476^{* * *}$ & $1.409^{* * *}$ & - & $1.531^{* * *}$ \\
\hline \multicolumn{10}{|l|}{ Control Variables } \\
\hline \multirow[t]{2}{*}{ Years of Arm. CONFlicts } & - & - & - & -0.0184 & - & - & - & $-0.0697^{* *}$ & -0.0228 \\
\hline & - & - & - & $(0.0272)$ & - & - & - & $(0.0354)$ & $(0.0342)$ \\
\hline \multirow[t]{2}{*}{ UNPK TROOPS/Mio. НAB. } & - & - & - & 0.00604 & - & - & - & 0.00470 & 0.00593 \\
\hline & - & - & - & $(0.00417)$ & - & - & - & $(0.00334)$ & $(0.00420)$ \\
\hline \multirow[t]{2}{*}{ Number of Amnesties } & - & - & - & - & 0.127 & - & - & 0.0170 & 0.157 \\
\hline & - & - & - & - & $(0.0998)$ & - & - & $(0.0910)$ & $(0.114)$ \\
\hline \multirow{2}{*}{ Int. CRiminal Tribunals } & - & - & - & - & 0.458 & - & - & 0.392 & 0.145 \\
\hline & - & - & - & - & $(0.922)$ & - & - & $(0.869)$ & $(0.971)$ \\
\hline \multirow[t]{2}{*}{ Form Colonial PoWer } & - & - & - & - & - & -1.544 & - & 0.0392 & -1.340 \\
\hline & - & - & - & - & - & $(1.403)$ & - & $(0.874)$ & $(1.525)$ \\
\hline \multirow[t]{2}{*}{ BIA Wiтh тне USA } & - & - & - & - & - & $-1.363^{* *}$ & - & $-1.605^{* * *}$ & $-1.450^{* *}$ \\
\hline & - & - & - & - & - & $(0.626)$ & - & $(0.469)$ & $(0.650)$ \\
\hline \multirow[t]{2}{*}{ COMmon LaW System } & - & - & - & - & - & - & -0.554 & -0.317 & -0.445 \\
\hline & - & - & - & - & - & - & $(0.563)$ & $(0.497)$ & $(0.614)$ \\
\hline \multirow[t]{2}{*}{ Parliamentary System } & - & - & - & - & - & - & 0.185 & $1.212^{* * *}$ & 0.285 \\
\hline & - & - & - & - & - & - & $(0.449)$ & $(0.370)$ & $(0.491)$ \\
\hline CONStant & $\begin{array}{c}-3.917^{* * * *} \\
(0.737)\end{array}$ & $\begin{array}{c}-2.590^{* * *} \\
(0.484)\end{array}$ & $\begin{array}{c}-6.073^{* * *} \\
(0.977)\end{array}$ & $\begin{array}{c}-6.071^{* * *} \\
(1.061)\end{array}$ & $\begin{array}{c}-6.635^{* * *} \\
(1.104)\end{array}$ & $\begin{array}{c}-4.845^{* * *} \\
(1.084)\end{array}$ & $\begin{array}{c}-5.984^{* * * *} \\
(0.978)\end{array}$ & $\begin{array}{c}1.346^{* * * *} \\
(0.458)\end{array}$ & $\begin{array}{c}-5.278^{* * *} \\
(1.225)\end{array}$ \\
\hline Observations & 193 & 193 & 193 & 193 & 193 & 193 & 193 & 193 & 193 \\
\hline Pseudo $R$-squared & 0.256 & 0.288 & 0.418 & 0.431 & 0.426 & 0.442 & 0.422 & 0.181 & 0.468 \\
\hline Log Likelihood & -94.487 & -90.463 & -73.939 & -72.263 & -72.889 & -70.765 & -73.391 & -103.926 & -67.506 \\
\hline
\end{tabular}

Standard errors in parentheses
$* * * \quad p<0.01, * * p<0.05, * p<0.1$

Table 39: Explaining States' Ratification of the Rome Statute (GL) 


\begin{tabular}{|c|c|c|c|c|c|}
\hline Variable & Coefficient $b$ & Odds Ratio & $\begin{array}{l}\text { \% Change in Odds } \\
\text { for Unit Change in } x\end{array}$ & Min. & Max. \\
\hline \multicolumn{6}{|l|}{ Explanatory Variables } \\
\hline Geneva LaW & $1.111^{* * *}$ & $3.037 * * *$ & $203.7 \%$ & 1 & 5 \\
\hline Political Freedom & $0.612^{* * *}$ & $1.843^{* * *}$ & $84.3 \%$ & 1 & 7 \\
\hline COMP. JuRISDICTION ICJ & $1.531^{* * *}$ & $4.622^{* * *}$ & $362 \%$ & 0 & 1 \\
\hline \multicolumn{6}{|l|}{ Control Variables } \\
\hline Years of Armed Conflicts & -0.022 & 0.978 & - & 0 & 75 \\
\hline UNPK TROOPS/Mio. НAB. & 0.006 & 1.006 & - & 0 & 671 \\
\hline Number of Amnesties & 0.157 & 1.170 & - & 0 & 10 \\
\hline Int. Criminal Tribunal & 0.145 & 1.156 & - & 0 & 1 \\
\hline Former Colonial Power & -1.340 & 0.262 & - & 0 & 1 \\
\hline BIA WITH THE USA & $-1.450^{* *}$ & $0.235^{* *}$ & $-76.6 \%$ & 0 & 1 \\
\hline COMmon LAW System & -0.445 & 0.641 & - & 0 & 1 \\
\hline PARLIAMENTARY SyStem & 0.285 & 1.330 & - & 0 & 1 \\
\hline
\end{tabular}

Table 40: Probabilities for Ratification of the Rome Statute in Full Model (GL) 


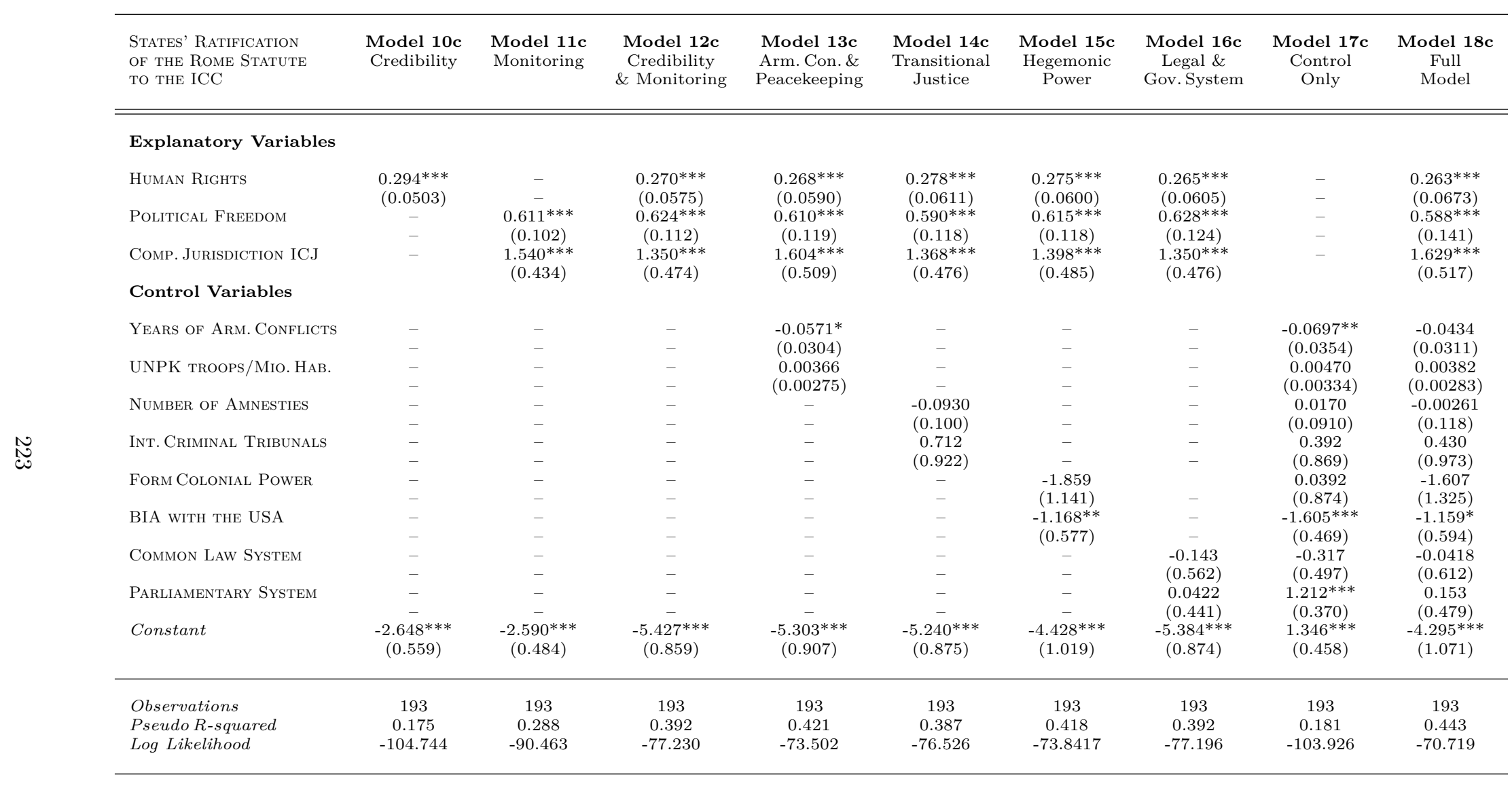

Standard errors in parentheses
$* * * \mathrm{p}<0.01,{ }^{* *} \mathrm{p}<0.05,{ }^{*} \mathrm{p}<0.1$

Table 41: Explaining States' Ratification of the Rome Statute (HR) 


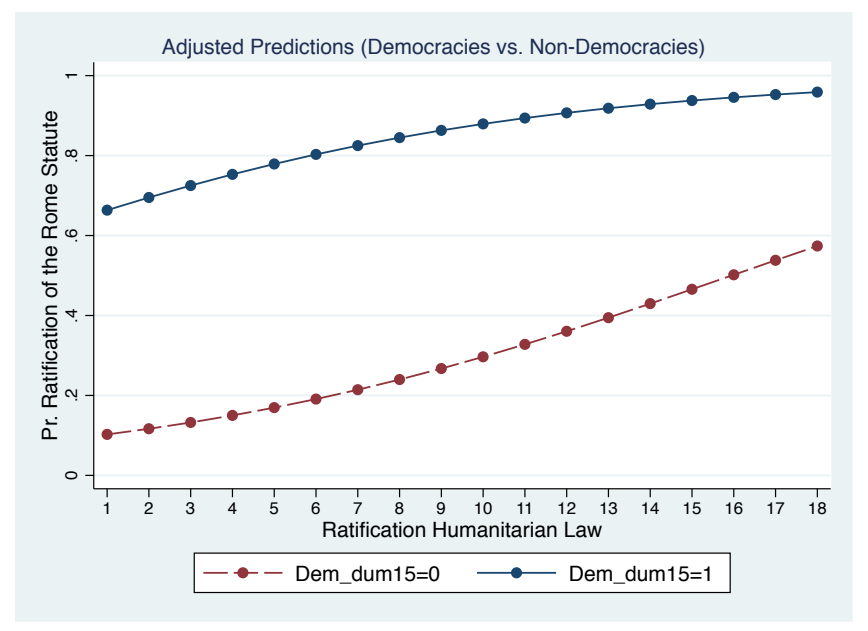

Figure 32: Adj. Pred. through Humanitarian Law (Democracies vs. Non-Democracies)

When we look at the conditional effects of democracy on the decision to ratify the Rome Statute we can see that the effects of having recognized the [C.J for compulsory jurisdiction (Figure 31, the commitment to humanitarian law Figure 32 or only to Geneva law Figure 33 and the commitment to human rights Figure 34 are significantly higher if a state is democratic than if it is non-democratic.

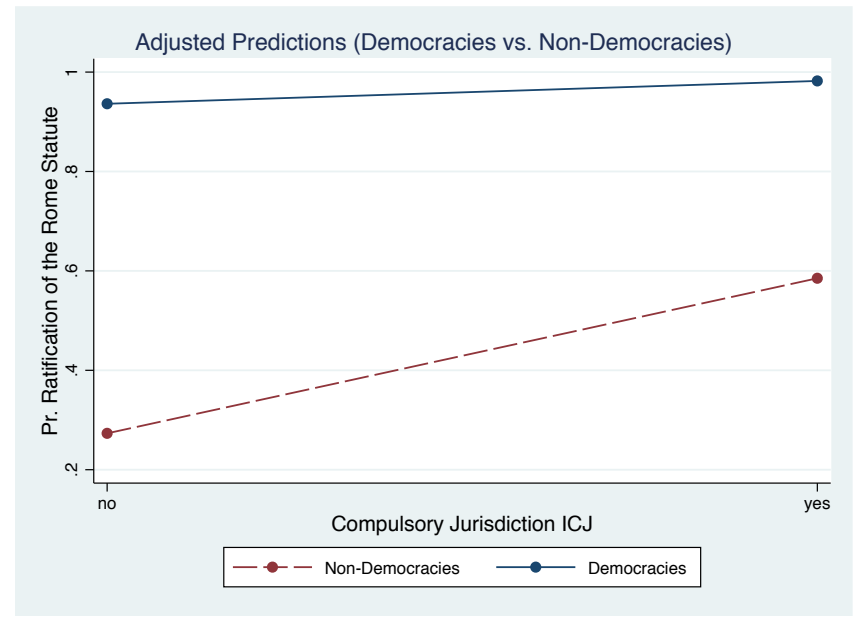

Figure 31: Adj. Pred. through Com. Jur. ICJ (Democracies vs. Non-Democracies) 


\begin{tabular}{|c|c|c|c|c|c|}
\hline Variable & Coefficient $b$ & Odds Ratio & $\begin{array}{l}\% \text { Change in Odds } \\
\text { for Unit Change in } x\end{array}$ & Min. & Max. \\
\hline \multicolumn{6}{|l|}{ Explanatory Variables } \\
\hline Human Rights & $0.263^{* * *}$ & $1.301^{* * *}$ & $30.1 \%$ & 2 & 18 \\
\hline Political Freedom & $0.588^{* * *}$ & $1.801^{* * *}$ & $80.1 \%$ & 1 & 7 \\
\hline COMP. JuRISDICTION ICJ & $1.629^{* * *}$ & $5.097 * * *$ & $409.7 \%$ & 0 & 1 \\
\hline \multicolumn{6}{|l|}{ Control Variables } \\
\hline Years of Armed Conflicts & -0.043 & 0.958 & - & 0 & 75 \\
\hline UNPK TROOPS/Mio. HAB. & 0.004 & 1.004 & - & 0 & 671 \\
\hline Number of Amnesties & -0.003 & 0.997 & - & 0 & 10 \\
\hline Int. Criminal Tribunal & 0.430 & 1.538 & - & 0 & 1 \\
\hline Former Colonial Power & -1.607 & 0.200 & - & 0 & 1 \\
\hline BIA WITH THE USA & $-1.159^{*}$ & $0.314^{*}$ & $-68.8 \%$ & 0 & 1 \\
\hline COMmon LAW System & -0.042 & 0.959 & - & 0 & 1 \\
\hline Parliamentary System & 0.153 & 1.165 & - & 0 & 1 \\
\hline
\end{tabular}

Table 42: Probabilities for Ratification of the Rome Statute (Full Model HR)

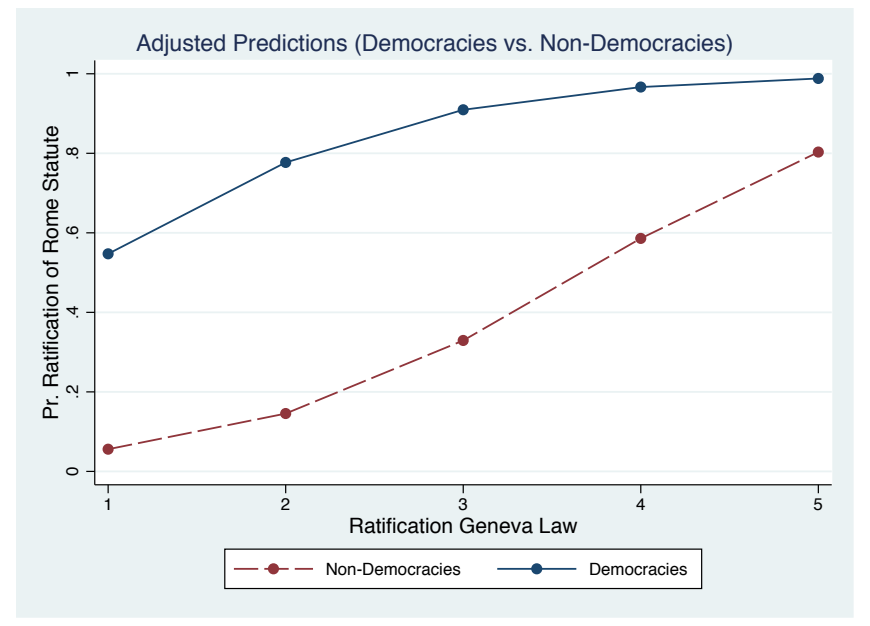

Figure 33: Adj. Pred. through Geneva Law (Democracies vs. Non-Democracies) 


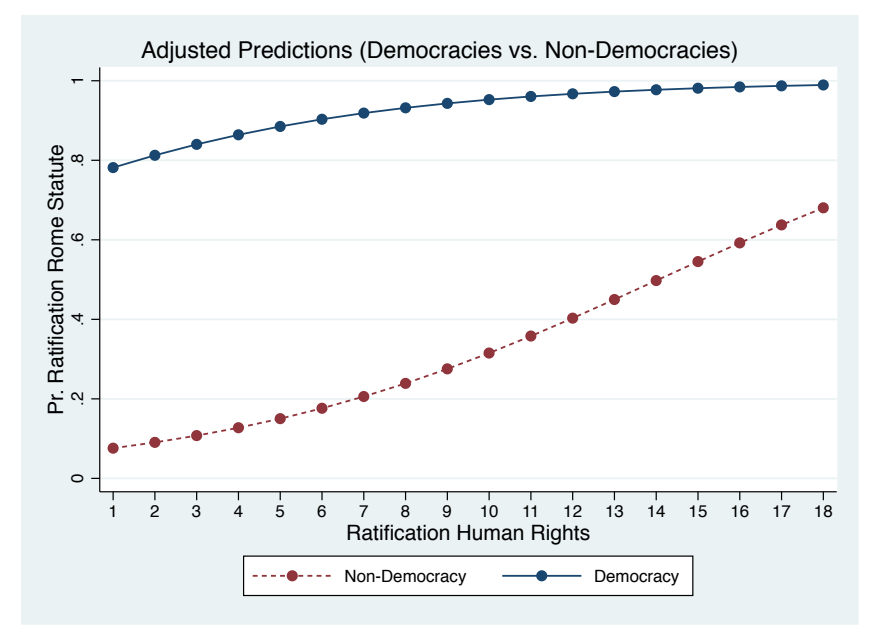

Figure 34: Adj. Pred. through Human Rights (Democracies vs. Non-Democracies)

In sum, we can say that the results fit to some extent to the results of other empirical studies on the states' decision to ratify the Rome Statue, that see e.g. the dependency of the states (Goodliffe et al. 2012) or the anticipated political costs of potential investigations and prosecutions of the ICC (Chapman/Chaudoin, 2013) as central determinants. However, referring to the theoretical argument of Simmons/Danner (2009. 2010) it can be argued that the level of democracy plays an important role for the states' behavior towards the ICC. There are many non-democratic states that have ratified the Rome Statute. However, those are mainly states with a comparatively high level of political freedom. Those that did not ratify the Rome Statute have a rather low level of political freedom. As the Index of Commitment to the ICC shows, their commitments are significantly less comprehensive than those of the states with a higher level of political freedom.

One conceivable interpretation of these empirical findings is that states are caught in the Delegation Dilemma to the ICC. They try overcome this by constraining and customizing their commitments to the ICC. They are motivated to do this because of the opportunity to reduce costs of monitoring humanitarian law and human rights. An additional motivation is the expected enhancement of their credibility on the world stage relating to their commitments to humanitarian law and human rights. 


\section{Conclusion and Outlook}

\subsection{Summary of the Results}

The present work has been driven by the puzzling fact that numerous democratic and even non-democratic states signed and ratified the Rome Statute to become a state party to the ICC, although this meant a serious intrusion into their national sovereignty. The questions arising from this included: 1) How strong is the commitment of states to the ICC beyond the ratification of the Rome Statute? And, 2) What explains the states' extent of commitment to the ICC? In order to answer these questions, the theoretical argument has been made that states customize and constrain their commitments to the ICC based on their possibilities solving cooperation problems with the ICC.

The reason for this is that states are caught in a delegation dilemma towards the ICC. There are strong incentives to ratify the Rome Statute and to become a state party. The states enjoy certain privileges of being party to the ICC, such as shaping or reshaping the institutional design as a member of the ASP which acts as a legislative power. Particularly, (post-)conflict states receive support in dealing with the past and promoting peace and democratization. However, above all, the court presents a possibility of solving cooperation problems of international law. While it is inherent in international law to promote cooperation among the states through the creation of legitimacy and predictability, it suffers often from a lack of compliance by the states to the law. The lack of enforcement mechanisms undermines the credibility of the states' commitment to the law. An international court, such as the ICC whose main purpose is to enforce international law, is able to reduce the high costs of monitoring human rights and humanitarian law and enhances the credibility of commitments to them.

Nonetheless, there are as well strong reasons not to become a state party. To some extent the ICC is missing clear institutional counterparts (Tomuschat, 2010) which makes its position in international relations unforeseeable. Hence, there is a widespread fear of the states that the court could be too weak on the international level and unable to cope with the power ambitions and particular interests of individual powerful states or political parties. These other states are their political opponents. There is a fear that the ICC could be become too strong and overly encumber the sovereignty of the states acting as an own political player. In the worst case it could go beyond the control of the states parties. We could say that international courts, such as the ICC, are like strong herding dogs without a master. They run the risk either of being too 
weak to guard their herd or being too strong and perhaps attack the herd they are meant to protect.

Thus, many states are caught in a delegation dilemma towards the ICC. Not ratifying the Rome Statute could mean waiving the privileges of being a state party or waiving support in dealing with the past and improving freedom and security. Conversely, ratifying the Rome Statute could mean a high risk of creating comparative disadvantages with respect to other states and therefore undermining their own freedom and security. This dilemma is further aggravated by the fact that those states that needs the ICC the most have the greatest cause for concern of negative consequences.

An appropriate solution for the states is to ratify the Rome Statute in order become a state party to the ICC, but to constrain and customize their commitments. This makes either investigations and prosecutions less likely or at least their consequences more foreseeable. The dimensions of a comprehensive commitment to the ICC are: joining the Rome Statute (DIM1); joining additional or amending agreements (DIM 2), such as the APIC or the amendments on the crime of aggression; making reservations or interpretative declarations under the agreements (DIM3); implementing norms on cooperation or complementarity into national law (DIM4); and triggering investigations on their own initiative (DIM5).

The Index of Commitment to The ICC was developed in order to measure the extent of such a comprehensive commitment. It is built as argument-based, weighted, additive index (Schnell et al., 2013, 159ff.) including the five dimensions of commitment in order to build a summary measurement for comprehensive commitment as latent variable. The Index of Commitment to the ICC varies from 0 to 12 points, in which 0 means no commitment and 12 means a comprehensive commitment to the ICC. Analyzing a grouped frequency distribution it became moreover possible to categorize the states into six groups of different levels of commitment to the ICC: COMPREHENsive Commitments (group 1), Slightly Customized Commitments (Group 2), Customized Commitments (group 3), Strongly Customized Commitments (group 4), Weak Commitments (Group 5), No or Very Weak COMMitment (GROUP 6). In this way 195 states were ranked on the index for 2016. Those measurement showed that there are numerous states with no or very weak commitment although being parties to the ICC. However, among the states parties to the ICC just under one-fifth of the states shows a comprehensive commitment, while the biggest group of states with one-third show strongly customized commitments 155

155 For the grouped frequency distribution on the states positions on the IndEx OF COMmitment to THE ICC see p.177 
The regression analyses have shown that the level of political freedom, the recognition of compulsory jurisdiction of the ICJ and the number of ratified treaties of humanitarian law and human rights make a decisive contribution to the explanation of the states' level of commitment to ICC. In making a robustness check, a multiple logistic regression analyses showed that these factors are likewise decisive in explaining the states' ratification of the ICC. However, the explained variance is bigger when explaining the index positions, than of the explained variance between states that ratified as opposed to those that did not. This is compatible with one of the core assumptions of the work, that states variation in different levels of commitment is bigger than its variation in deciding on the mere ratification of the Rome Statute to become a state party to the court.

\subsection{Contribution to Research on the ICC}

In particular in the areas of human rights law and humanitarian law, we know meanwhile that especially non-democratic states, but also democratic states tend to ratify human rights treaties as a form of window dressing (Simmons, 2009) or under pressure from transnational civil actors (Hathaway, 2002) or international organizations, while those ratifications often remain being 'empty promises' Hafner-Burton/Tsutsui 2005). The single act of ratification is not an appropriate indicator of states commitment to international law in general and human rights in particular. Instead, there is a need for more fine-grained measurements for commitments to certain legal agreements or even judicial institutions such as international courts and tribunals.

The Index of Commitment to the ICC can be considered as such a finer measurement tool for looking at states' commitment to the ICC. The conceptualization of comprehensive commitments and the theoretical argument of states behavior due to their possibilities of solving cooperation problems of international law contribute twofold to the IR research on states' behavior towards international courts and tribunals in general and the ICC in particular. For one thing, it makes it possible to open the black box of states parties to the ICC. Building an index as a summary measurement of comprehensive commitment captures commitment to the ICC beyond the mere ratification of the Rome Statute. This includes several indicators for commitment, such as binding to additional or amending agreements or making reservations or interpretative declarations to them. Thus, the dichotomy of states parties and non-party states is deconstructed. Further, it is able to measure variation, especially among the group of states parties to the Rome Statute. 
The index shows clearly that 'commitment is not commitment', but there is a huge variation in the extent of the states' willingness to be bound to the ICC. We cannot conclude automatically that states with a high level of commitment are more likely to comply with core crimes of the Rome Statute, nor are they more likely to cooperate with the court according to the procedural norms. Or, conversely, that states with low levels of commitment are less likely. Nevertheless, it gives us valuable clues for different levels of the states' self-binding to the ICC. It makes it possible to relate them with explanatory approaches of states behavior towards international courts and tribunals.

The second research contribution of the present work is that it develops a theoretical argument on varying degrees of benefits solving of cooperation problems through the commitment to the ICC. This makes allowance for the fact that although there are strong incentives to commit themselves, such as the reduction of costs of monitoring the compliance with humanitarian law and human rights or enhancing credibility of commitments to humanitarian law and human rights, those incentives do not inevitably lead to benefits for all states in the same way. For states that are neither involved nor interested in the monitoring of the humanitarian law and human rights there is no advantage in reducing costs of monitoring humanitarian law and human rights. For states that have only a very low level of commitment to humanitarian law and human rights there is little reason to make those commitments more credible. On the contrary, we can expect those states to have incentives to hinder the strengthening of the ICC. Receiving empirical evidence on the states' diverging incentive structures due to their possibility of solving cooperation problems with the ICC gives us valuable insights in states' motives for committing to an international agreement or delegating authority to an international court.

This might raise awareness of the fact that it is too simplified to claim that all states would have the same benefits of creating a certain international court or dispute settlement mechanism due to its issue areas. Alter (2004) considers that delegation of authority depends on the aims of reducing transaction costs or enhancing credibility and thus makes the distinction between courts as agents or trustees. Koremenos (2007) argues that delegation depends on the complexity of cooperation problems to be solved. In this sense, the present work hopes to raise awareness for the influence of states' diverging incentives to commit to international law and to delegate authority to international courts, such as the ICC, even if there are potentially common cooperation problems to be solved. 
Recognizing that there was a 'justice cascade' (Sikkink, 2011) from the Nuremberg and Tokyo trials over some of the core treaties of humanitarian law and human rights law leading up to the establishment of the ICC and the creation of an universal norm of criminal accountability, we can argue that the states behavior towards the court is connected with their position towards humanitarian law and human rights as they are trapped in a delegation dilemma towards the ICC and have to weigh their commitment dependent on the commitments they made to humanitarian law and human rights.

\subsection{Limits of Empirical Results and Need for Further Research}

As a matter of course, the assumptions and empirical results of the present work has its limits. There are two important identifiable limitations on the empirical results. First, probably the most important limitation is due to the availability of data on implementation of norms on complementarity and cooperation into national law. Even though the CICC collects data on implementation of both norms and complementarity and cooperation, these are published in a continuously updated form. It is not possible to see when these changes occurred after it has been updated. That means it is not possible to assign certain levels of implementation to certain years. It would be more favorable to collect data on implementation on a yearly basis. A time-series data set on comprehensive commitment for 1998-hitherto with data points per year per countries could be created in this way. This would allow for a 'pooled times-series cross-section analysis' 156 This would allow it to gather stronger evidence to test the hypotheses on the states' incentives due to their possibilities in solving cooperation problems. Then it would be possible to measure effects of time. We expect the states need different time frames to obtain ratification or implementation. Finally, it would allow for testing of the relation of reoccurring waves of commitment to certain political events.

The second limitation of the results which needs further research is seen in the conceptualization of comprehensive commitment that is mainly focused on formal commitment to the ICC. The Index of Commitment To THE ICC shows a high robustness. The OLS testing explanations for the states' index positions and the results of the logistic regression testing explanations for the ratification show very similar patterns. Nevertheless, it has to be accepted that the index measures first and foremost formal commitment. It focuses mainly on behavior towards agreements. Only the dimension of triggering investigations and prosecutions brings in a dynamic aspect. In the course of a larger research project it would possible to include further aspects of commitment

$\overline{156 \text { For the influence on the limitation of }}$ data on implementation see p. 161 and on p. 192 
that include stronger political dimensions, such as the amount of financial contribution and their payment within the negotiated time frames; the engagement in the ASP as legislative power or the voluntarily conclusion of enforcement agreements regarding execution of sentences. Particularly, in the case of the USA's non-commitment, we could attempt to measure their actual attitude towards the ICC. The USA reaches only 0 points on the Index of Commitment to the ICC. However, this does not mean that there are no political groups supporting international law and the ICC. Because it would be even harder to collect data on those more political aspects on an annual basis, it would be better to carry out comparative cases studies on the political aspects based on a strategic case selection.

Further research to supplement the results of the present studies would be worthwhile. By means of comparative case studies based on strategic case selection it would be possible researching certain patterns that occur within the INDEX OF COMMITMENT TO THE ICC as e.g. the similar commitment behavior of states according to their membership of certain regional organization: ${ }^{157}$ and could be indicators for effects of political 'diffusion', such as the case of EU where members tend to have a very high level of commitment, the ASEAN that tend to have a very low level of commitment or the $\mathrm{AU}$ in which members show a very high variation in their levels of commitment to the ICC. Furthermore, it can be observed that some rivaling, or conflicting pairs of states show a totally different commitment behavior to the ICC, such as Israel and Palestine ( 0 vs. 7.5 index points), North Korea and South Korea (0 vs. 9 index points), or India and Bangladesh (0 vs. 5 index points) or Haiti and the Dominican Republic (0.5 vs. 7 index points). That provides an interesting opportunity to test further arguments on politicization or at least strategical behavior dependent on political conditions. Comparative case studies based on strategic case selections (e.g. typical cases from each group of commitment, perhaps within a most-similar-systems design) would allow research of the relationship of (formal) commitment to the ICC and compliance with the Rome Statute.

Another important aspect for further research might include the inverse connection between commitments to humanitarian law and human rights and the commitment behavior towards the ICC. In the present work, it has been argued that the commitment behavior to humanitarian law and human rights as independent variables has a crucial influence on the commitment behavior to the ICC as dependent variable. However, we can expect a relationship vice versa, too. Does the genesis and the strengthening of the ICC have an influence on the ratification rates of treaties of humanitarian law and

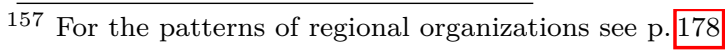


human rights? We can expect this especially in those cases were the states make credible commitment to the ICC promoting a universal norm of criminal accountability and strengthening peace and security in international relations. It would be rewarding to approach this relation systematically.

\subsection{Why Constrained Commitments Can Still Lead to Strong Bonds}

The establishment of international courts and tribunals are phenomenons and catalysts of the legalization and judicialization of international relations. However, states as authors, guards and addressee of international law remain in a dilemma towards international courts and tribunals. On the one hand, they need the courts and tribunals to solve cooperation problems of international law, such as a lack of compliance. Speaking metaphorically, we can say that the logic and design of national criminal courts at the level of international relations is like putting a fish from a garden pond into a puddle of muddy water and then hoping it will survive.

On the other hand, states have to be cautious towards courts since the state cannot properly evaluate the long-term consequences of being state party to a court. The international courts could turn out to be too weak to cope with power ambitions and particular interests of individuals states. Or, they could become to strong and overreach their mandate, dominate the agenda or in the worst case get out of the states' control.

Since the legalization of international relations is strongly influenced by international security interests, domestic interests and preferences as well as diverging norms and ideas, we can consider anarchy being still both dead and alive ${ }^{158}$, as long as we do not look in the box of empirical reality with methods of social sciences.

Thus, the acceptance threshold of states to international courts is only slowly and cautiously rising, particularly in case of those states that are affected the most, whereas positive effects of thrusts of transition from autocracy to democracy cannot be ruled out. It matters most how the states for one thing are interested in participating in the governance of the global community and thus a reduction of monitoring costs through the establishment of the ICC and for another thing have made commitments to humanitarian law and human rights already and thus enhancing the credibility of commitments with the delegation of authority to the ICC.

158 The consideration of anarchy being dead and alive relies on Steinberg (2013) who argues that realism is even in areas of legalization still relevant. 
This behavior of the states can be considered as an expression of behavior towards courts that (Locke 1967 [1689]), father of Liberalism, made yet in the recent days of sovereign nations. He argued that one only submits to a superior authority if and as long as these are able to protect the security of the subjected and it is no longer necessary to protect one's security itself.

"For all Power given with trust for the attaining an end, being limited by that end, whenever that end is manifestly neglected, or opposed, the trust must necessarily be forfeited, and the Power devolve into the hands of those that gave it, who may place it anew where they shall think best: for their safety and security. And thus the Community perpetually retains a Supreme Power of saving themselves from the attempts and designs of any Body, even of their Legislators, whenever they shall be so foolish, or so wicked, as to lay and carry on designs against the Liberties and Properties of the Subject." (para. 149) (Locke, 1967 [1689] 385)

International courts, such as the ICC, however, are based on the respect of sovereignty and the principle of complementarity. They are not designed to protect the security of the states. Even if states are parties to the court, they have to protect their sovereignty in order to remain capable to protect their security towards the international courts and towards the other states. One might argue that it was never the aim of the ICC to protect the states comprehensively. The ICC is designed consciously as court of complementarity, not the least of which because this was the only chance to win over the states for the 'project international criminal law'. In addition to the dilemma with which the states are confronted, the courts are confronted by the decision as to whether one should harden the rules or increase the number of states parties. Nevertheless, we have to concede that we cannot expect the states to commit comprehensively to an international court that is not able to adequately protect. Instead, we have to anticipate further constraints and customization of commitments and subsequent cases of non-cooperation.

However, this does not mean that the ICC is a 'illusionary giant' in that sense that it seems to be very powerful when viewed from a certain distance but becomes smaller and smaller the nearer it comes. On the contrary, we can expect even slower adoption and customization or constraint commitments that lead to strong bonds in the mediumand long-term since being a state party to the ICC can change domestic structures and can change international norms.

As is often the case in international politics we can expect the states changing behavior because of entrapment and sunk costs (Scharpf, 1985) and thus lock-in-effects (Mahoney, 2000). Solely, the ratification of international law can influence the domestic political agenda, the litigation of domestic courts and thereby the mobilization of civil 
society (Simmons, 2009, 112ff.). Thus, the recognition of the Rome Statute is able to change domestic politics.

"[R]atified treaties can influence agenda, litigation, and mobilization in ways that should be observable in government policies post-ratification. Treaties change politics - in particular, the domestic politics of the ratifying country. While their enforcement internationally tends to create collective action problems that state actors have few incentives to overcome, the consequences locally can be profound." (Simmons 2009, 113)

Commitments to the ICC can become self-enforcing through domestic actors, even if the ratifying states did not intend to bind themselves effectively. In the introduction one example was given regarding the non-cooperation of South Africa during the state visit of Sudanese President Omar al-Bashir. Although an international arrest warrant had been issued for him, South African knowingly let him pass unhindered in June 2015. While there are voices claiming this would be an indicator for the ICC's weakness 159 one has to take into account that the Supreme Court of Appeal of South Africa ruled in 2016 that it was an unlawful failure not to arrest Omar al-Bashir and spoke of a 'disgraceful conduct ${ }^{160}$. Following the South African legal procedure, the Pre-Trial Chamber of the ICC convened hearing in April 2017. Lastly in July 2017 the Pre-Trial Chamber II ruled against South African and expressed that South Africa have had a duty to arrest the Sudanese president Omar Al-Bashir ${ }^{161}$ This shows that domestic legal structures and political actors play a crucial role in the process of integration of the ICC and thus the implementation of norms on complementarity and cooperation can be considered as important indicator for a credible commitment to the ICC.

We can expect the ICC to strengthen international criminal law and its core crimes of genocide, crimes against humanity, war crimes and the crime of aggression. With the establishment of the IMT and the IIMTFE and the legal application of the crime of genocide and the crimes against humanity the course was set for an international recognition of them as an international applicable law (Sands, 2016). Because of their enforcement through the ICC and the numerous theoretical and political reflections, we can expect them to stabilize as global recognized international norms.

\footnotetext{
159 For reporting on the escape of Omar al Bashir from South Africa see e.g 'The Guardian' of 16 June 2015 https://www. theguardian. com/world/2015/jun/16/ omar-al-bashir-escape-south-africa-african-union (01-08-2017) or 'The New York Times' of 16 June 2015 https://www.nytimes.com/2015/06/16/world/africa/ omar-hassan-al-bashir-sudan-south-africa.html (01-08-2017).

160 The Supreme Court of Appeal of South Atrica Judgment, Case no: 867/15, para. 7 .

${ }^{161}$ ICC Pre-Trial Chamber II, No. ICC-02/05-01/09, decision under article 87(7) of the Rome Statute on the non-compliance by South Africa with the request by the Court for the arrest and surrender of Omar Al-Bashir, para. 127.
} 
Those international norms provide precedent for certain political parties, even if their states are not yet willing to be part of the ICC, such as in the case of the Ukraine. The Ukraine is not party to the ICC but made a declaration under article 12(3) of the Rome Statute recognizing the jurisdiction of the ICC with respect to alleged crimes committed on its territory from 20 February 2014 onward. This has made it possible to investigate and prosecute the violent event in the context of the Maidan protests.

We have to recognize that cases brought to courts are always a mirror of the social and political reality. These cases are sometimes present an opportunity to express the own political interests.

\footnotetext{
"A court of law is a theater, temple and battlefield. A court enacts social process as drama, sacrament and contest. Day after day in the court-room the magic of human self-socializing is performed publicly, for all to see: the universal made particular, the particular made universal. (...) Like any other social institution, a court is a transformatory structure-system, transforming social reality in particular ways. Itself the product of the past social reality of a particular society, a court makes a specific contribution to the general social task of forming a given society's future out of that society's past, as it acts in society's continuous present." (Allott 1996 17)
}

According to Shelton (2009,5) a court is always shaped by political interests, since its mission is to rule based on the law that was developed in a political process. Probably, all disputes that are tried at international courts and tribunals are political. The challenge is to solve them legally.

In the long run, the ICC has the potential to be integrated more and more into domestic and international politics. Perhaps one day it will be possible to protect the states and their civil societies from genocide, crimes against humanity, war crimes and the crime of aggression. The states will have subordinated themselves to international law more than they do today. This, however, depends upon the laws capability to be taken seriously and it depends upon whether the states are meaningfully discouraged from withdrawing themselves from investigations and prosecutions no matter how strong they have constrained and customized commitments. The ICC should concentrate on a few specific cases that are brought to an end that lead to consequences for the identified perpetrators of international criminal law. At the same time, the domestic rule of law of the states has to be strengthened so that the universal norm of criminal accountability becomes a domestic reality. The reconciliation between this very necessary international tool and the domestic reality of the state would allow us to say: A commitment is a commitment is a commitment. 


\section{Appendices}

\subsection{List of States Parties to the Rome Statute (08-2016)}

States Parties to the ICC $(123 / 195)$

Afghanistan, Albania, Andorra, Antigua and Barbuda, Argentina, Australia, Austria, Bangladesh, Barbados, Belarus, Belgium, Belize, Benin, Bolivia, Bosnia and Herzegovina, Botswana, Brazil, Bulgaria, Burkina Faso, Central African Republic, Cambodia, Canada, Cape Verde, Chad, Chile, Colombia, Comoros, Congo, Cook Islands, Costa Rica, Croatia, Cyprus, Czech Republic, Democratic Republic of Congo, Denmark, Djibouti, Dominica, Dominican Republic, Ecuador, El Salvador, Estonia, Ethiopia, Fiji, Finland, France, Gabon, Gambia, Georgia, Germany, Ghana, Greece, Grenada, Guatemala, Guinea, Honduras, Hungary, Iceland, Ireland, Italy, Ivory Coast, Japan, Jordan, Kenya, Republic of Korea, Latvia, Lesotho, Liberia, Liechtenstein, Lithuania, Luxembourg, Macedonia, Madagascar, Malawi, Maldives, Mali, Malta, Marshall Islands, Mauritius, Mexico, Republic of Moldova, Mongolia, Montenegro, Namibia, Nauru, Netherlands, New Zealand, Niger, Nigeria, Norway, Palestine, Panama, Paraguay, Peru, Philippines, Poland, Portugal, Romania, Samoa, San Marino, St. Kitts and Nevis, St. Lucia, St. Vincent and the Grenadines, Senegal, Serbia, Seychelles, Sierra Leone, Slovakia, Slovenia, South Africa, Spain, Suriname, Sweden, Switzerland, Tajikistan, United Republic of Tanzania,Timor-Leste, Trinidad and Tobago, Tunisia, Uganda, United Kingdom, Uruguay, Vanuatu, Venezuela, Zambia

Non-Party States to the ICC (Signed, But Not Ratified) (28/195)

Algeria, Angola, Armenia, Bahamas, Bahrain, Cameroon, Egypt, Eritrea, Guinea-Bissau, Haiti, Islamic Republic of Iran, Jamaica, Kuwait, Kyrgyzstan, Monaco, Morocco, Mozambique, Oman, Russian Federation, Sao Tome and Principe, Solomon Islands, Syrian Arabic Republic, Thailand, Ukraine, United Arab Emirates, Uzbekistan, Yemen, Zimbabwe

Non-Party States to the ICC (Not Signed 43/195)

Azerbaijan, Belarus, Bhutan, Brunei, Burund ${ }^{162}$ China, Cuba, Equatorial Guinea, Guyana, India, Indonesia, Iraq, Israel, Kazakhstan, Democratic People's Republic of Korea, Kiribati, Lao People's Democratic Republic, Lebanon, Libya, Malaysia, Mauritania, Micronesia, Myanmar, Nepal, Nicaragua, Pakistan, Palau, Papua New Guinea, Qatar, Rwanda, Saudi Arabia, Singapore, Somalia, South Sudan, Sudan, Sri Lanka, Swaziland, Togo, Tonga, Turkey, Turkmenistan, Tuvalu, United States of America, Vietnam 
7.2 Puzzle: Ratification and Democracy (08-2016)

\begin{tabular}{|c|c|c|c|}
\hline & non-democracy & democracy & \\
\hline $\begin{array}{l}\text { no } \\
\text { state party }\end{array}$ & $\begin{array}{l}59 \text { non-surprising states: } \\
\text { Algeria, Angola, Armenia, Azerbaijan, Bahrain, Belarus, Bhutan, } \\
\text { Brunei, Cameroon, China, Cuba, DPR Korea, Equatorial Guinea, } \\
\text { Egypt, Eritrea, Ethiopia, Guinea-Bissau, Haiti, Indonesia, Iran, } \\
\text { Iraq, Kazakhstan, Kuwait, Kyrgyzstan, Laos, Lebanon, Libya, } \\
\text { Malaysia, Mauritania, Morocco, Mozambique, Myanmar, Nepal, } \\
\text { Nicaragua, Oman, Pakistan, Papua New Guinea, Qatar, Rus- } \\
\text { sia, Rwanda, Saudi Arabia, Singapore, Solomon Islands, Soma- } \\
\text { lia, South Sudan, Sri Lanka, Sudan, Swaziland, Syria, Thailand, } \\
\text { Togo, Turkey, Turkmenistan, Ukraine, United Arab Emirates, } \\
\text { Uzbekistan, Vietnam, Yemen, Zimbabwe }\end{array}$ & $\begin{array}{l}12 \text { surprising states: } \\
\text { Bahamas, Kiribati, India, Israel, Jamaica, Micronesia, Monaco, Palau, } \\
\text { Sao Tome and Principe, Tonga, Tuvalu, United States of America }\end{array}$ & 71 \\
\hline state party & $\begin{array}{l}50 \text { surprising states: } \\
\text { Afghanistan, Albania, Bangladesh, Bolivia, Bosnia and Herze- } \\
\text { govina, Burkina Faso, Burundi, Cambodia, Central African Re- } \\
\text { public, Chad, Colombia, Comoros, Djibouti, DR Congo, Do- } \\
\text { minican Republic, Ecuador, Fiji, Gabon, Gambia, Georgia, } \\
\text { Guatemala, Guinea, Honduras, Ivory Coast, Jordan, Kenya, } \\
\text { Lesotho, Liberia, Macedonia, Madagascar, Malawi, Mali, Mal- } \\
\text { dives, Mexico, Moldova, Montenegro, Niger, Nigeria, Palestine, } \\
\text { Paraguay, Philippines, Rep. of Congo, Seychelles, Sierra Leone, } \\
\text { Tajikistan, Tanzania, Timor-Leste, Uganda, Venezuela, Zambia }\end{array}$ & $\begin{array}{l}74 \text { non-surprising states: } \\
\text { Andorra, Antigua and Barbuda, Argentina, Australia, Austria, Barba- } \\
\text { dos, Belgium, Belize, Benin, Botswana, Brazil, Bulgaria, Canada, Cape } \\
\text { Verde, Chile, Cook Islands, Costa Rica, Croatia, Cyprus, Czech Repub- } \\
\text { lic, Denmark, Dominica, El Salvador, Estonia, Finland, France, Germany, } \\
\text { Ghana, Greece, Grenada, Guyana, Hungary, Iceland, Ireland, Italy, Japan, } \\
\text { Latvia, Liechtenstein, Lithuania, Luxembourg, Malta, Marshall Is., Mau- } \\
\text { ritius, Mongolia, Namibia, Nauru, Netherlands, New Zealand, Norway, } \\
\text { Panama, Peru, Poland, Portugal, Romania, Samoa, San Marino, South } \\
\text { Korea, St.Kitts a. Nevis, St.Lucia, St.Vincent a. Grenadines, Senegal, Ser- } \\
\text { bia, Slovakia, Slovenia, South Africa, Spain, Suriname, Sweden, Switzer- } \\
\text { land, Trinidad and Tobago, Tunisia, United Kingdom, Uruguay, Vanuatu }\end{array}$ & 124 \\
\hline & 109 & 86 & \\
\hline
\end{tabular}

Table 43: Contingency Table - Ratification of the Rome Statute \& Political Freedom 


\subsection{List of Treaties on Humanitarian Law (08-2015)}

Parties Humanitarian law Agreement

196 1. Geneva Conventions (I-IV)

Geneva Convention (I) for the Amelioration of the Condition of the Wounded and Sick in Armed Forces in the Field, Geneva 1949.

Convention (II) for the Amelioration of the Condition of Wounded, Sick and Shipwrecked Members of Armed Forces at Sea, Geneva 1949.

Convention (III) relative to the Treatment of Prisoners of War, Geneva 1949

Convention (IV) relative to the Protection of Civilian Persons in Time of War, Geneva 1949

174 2. Protocol Additional to the GCs of 1949, and relating to the Protection of Victims of International Armed Conflicts (API), Geneva 1977.

76 3. Declaration provided for under art. 90 AP I. Acceptance of the Competence of the Int. Fact-Finding Commission according to art. 90 of AP I.

4. Protocol Additional to the GCs of 1949, and relating to the Protection of Victims of Non-International Armed Conflicts (APII), Geneva 1977.

5. Protocol Additional to the GCs of 1949, and relating to the Adoption of an Additional Distinctive Emblem (APIII), Geneva 2005.

6. Convention on the Prevention and Punishment of the Crime of Genocide, Paris 1948.

7. Convention on the Non-Applicability of Statutory Limitations to War Crimes and Crimes against Humanity, New York 1968.

8. Convention for the Protection of Cultural Property in the Event of Armed Conflict, The Hague 1954.

9. First Protocol to the Hague Convention of 1954 for the Protection of Cultural Property in the Event of Armed Conflict, The Hague 1954

10. Second Protocol to the Hague Convention of 1954 for the Protection of Cultural Property in the Event of Armed Conflict, The Hague 1999.

11. Con. on the Prohibition of Military or Any Other Hostile use of Environmental Modification Techniques, New York 1976.

Treaties on the Use of Weapons in Armed Conflicts

12. Protocol for the Prohibition of the Use of Asphyxiating, Poisonous or Other Gases, and of Bacteriological Methods of Warfare, Geneva, 1925

13. Con. on the Prohibition of the Development, Production and Stockpiling of Bacteriological (Biological) and Toxin Weapons (...), London u.a. 1972.

14. Con. on Prohibitions or Restrictions on the Use of Certain Conventional Weapons which may be deemed to be Excessively Injurious (...), Geneva 1980.

15. Protocol on Non-Detectable Fragments (PI), Geneva 1980.

16. Protocol on Prohibitions or Restrictions on the Use of Mines, Booby-Traps and Other Devices (PII), Geneva 1980.

17. Protocol on Prohibitions or Restrictions on the Use of Incendiary Weapons (PIII), Geneva 1980

18. Protocol on Blinding Laser Weapons (Protocol IV), Vienna 1995.

19. Protocol on Prohibitions or Restrictions on the Use of Mines, Booby-Traps and Other Devices as amended 1996 (PII as amended 1996), Geneva 1996.

20. Amendment to the Con. on Prohibitions or Restrictions on the Use of Certain Conventional Weapons (...), Geneva 2001.

21. Protocol on Explosive Remnants of War (PV), Geneva 2003

22. Con. on the Prohibition of the Development, Production, Stockpiling and Use of Chemical Weapons (...), Paris 1993.

23. Con. on the Prohibition of the Use, Stockpiling, Production and Transfer of Anti-Personnel Mines and on their Destruction, Oslo 1997.

24. Convention on Cluster Munitions, Dublin 2008.

25. Arms Trade Treaty, New York 2013.

Table 44: List of Humanitarian Law Treaties 


\subsection{List of Treaties on Human Rights (08-2015)}

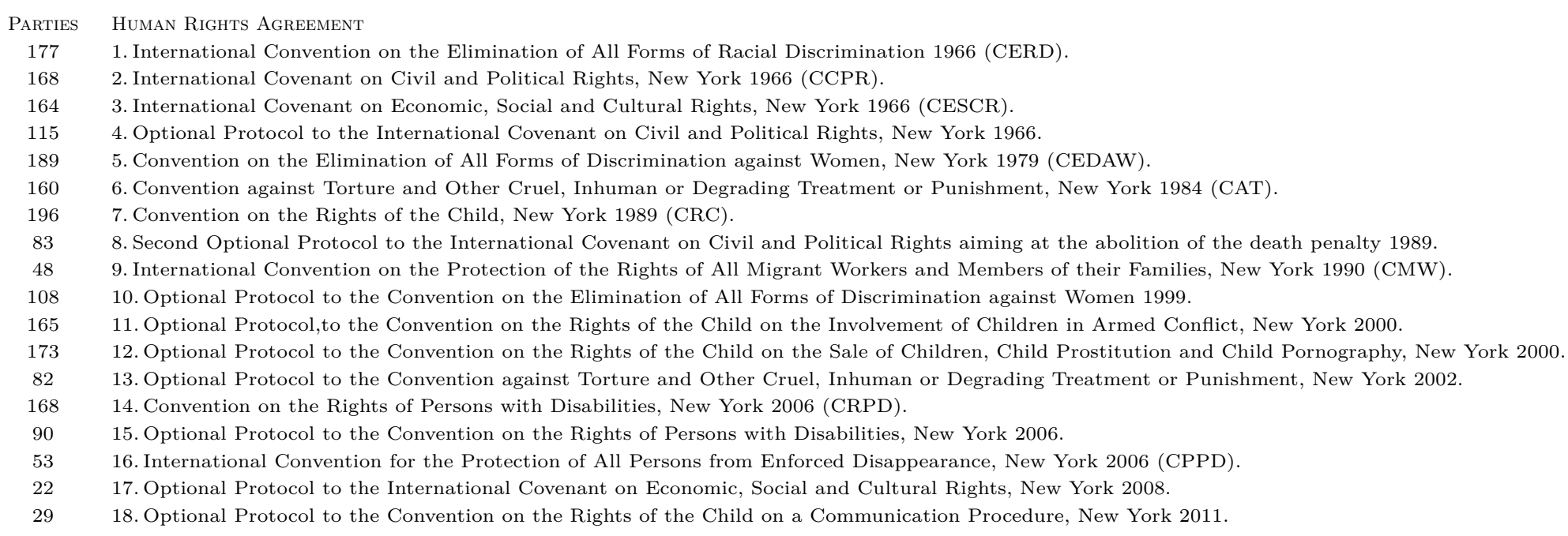

Table 45: List of Human Rights Treaties 
7.5 Examination of Robustness: Index of Commitment to the ICC Scores per Variable

\begin{tabular}{|c|c|c|c|}
\hline Dimension & Commitment to the ICC (Variables) & Scores/Variable & Scores/Dimension \\
\hline JoINING (Dim 1) & $\begin{array}{l}\text { signature Rome Statute } \\
\text { ratification Rome Statute }\end{array}$ & $\begin{array}{l}1.00 \\
1.00\end{array}$ & 2.00 \\
\hline AMENDing (Dim 2) & $\begin{array}{l}\text { signature APIC } \\
\text { ratification APIC } \\
\text { amendment to art. } 8 \\
\text { crime of Aggression }\end{array}$ & $\begin{array}{l}1.00 \\
1.00 \\
1.00 \\
1.00\end{array}$ & 4.00 \\
\hline ModiFying (Dim 3) & $\begin{array}{l}\text { Rome Statute of the ICC } \\
\text { APIC } \\
\text { amendment to art. } 8\end{array}$ & $\begin{array}{l}1.00 \\
1.00 \\
1.00\end{array}$ & 3.00 \\
\hline IMPLEMENTING (Dim 4 ) & $\begin{array}{l}\text { cooperation (in progress/issued) } \\
\text { complementarity (in progress/issued) }\end{array}$ & $\begin{array}{l}1.00 \\
1.00\end{array}$ & 2.00 \\
\hline Triggering (Dim 5) & art. 14/art.12(a) Rome Statute & 1.00 & 1.00 \\
\hline
\end{tabular}

Table 46: Dimensions of the Index - Scores per Variables

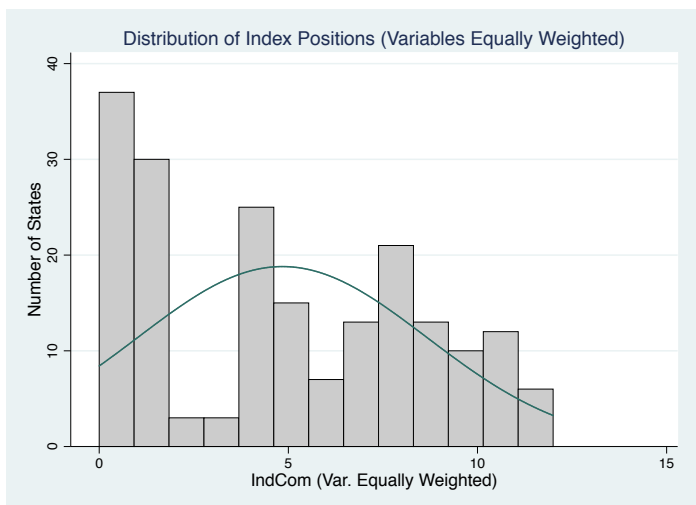

Figure 35: Frequency Distribution - Index (Scores per Variable) 


\section{Scores per Dimension}

\begin{tabular}{|c|c|c|c|}
\hline Dimension & Commitment to the ICC (Variables) & Scores/Variable & Scores/Dimension \\
\hline JoInING (Dim 1 ) & $\begin{array}{l}\text { signature Rome Statute } \\
\text { ratification Rome Statute }\end{array}$ & $\begin{array}{l}1.00 \\
1.50\end{array}$ & 2.50 \\
\hline AMENding (Dim 2) & $\begin{array}{l}\text { signature APIC } \\
\text { ratification APIC } \\
\text { amendment to art. } 8 \\
\text { crime of Aggression }\end{array}$ & $\begin{array}{l}0.25 \\
0.75 \\
0.75 \\
0.75\end{array}$ & 2.50 \\
\hline Modifying (Dim 3) & $\begin{array}{l}\text { Rome Statute of the ICC } \\
\text { APIC } \\
\text { amendment to art. } 8\end{array}$ & $\begin{array}{l}1.00 \\
0.75 \\
0.75\end{array}$ & 2.50 \\
\hline IMPLEMENTING (Dim 4 ) & $\begin{array}{l}\text { cooperation (in progress/issued) } \\
\text { complementarity (in progress/issued) }\end{array}$ & $\begin{array}{l}1.25 \\
1.25\end{array}$ & 2.50 \\
\hline Triggering (Dim 5 ) & art. 14/art.12(a) Rome Statute & 2.00 & 2.00 \\
\hline
\end{tabular}

Table 47: Dimensions of the Index - Scores per Dimension

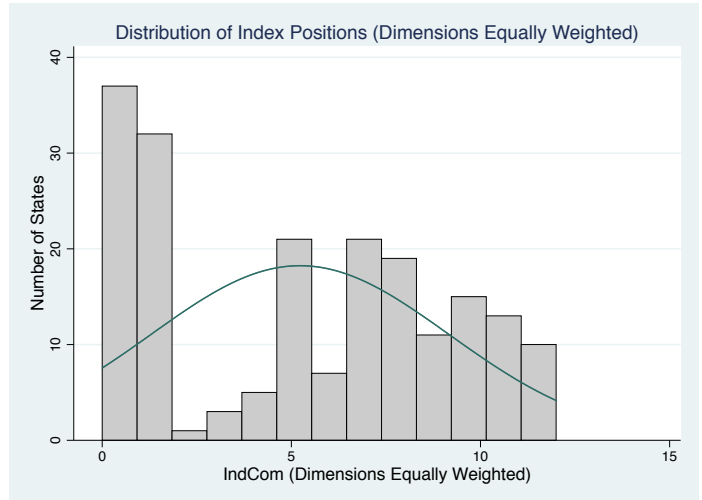

Figure 36: Frequency Distribution - Index (Scores per Dimension) 


\section{Ratification as Strongest Factor}

\begin{tabular}{|c|c|c|c|}
\hline Dimension & Commitment to the ICC (Variables) & Scores/Variable & Scores/Dimension \\
\hline JoInING (Dim 1 ) & $\begin{array}{l}\text { signature Rome Statute } \\
\text { ratification Rome Statute }\end{array}$ & $\begin{array}{l}1.00 \\
3.00\end{array}$ & 4.00 \\
\hline AMENding (Dim 2) & $\begin{array}{l}\text { signature APIC } \\
\text { ratification APIC } \\
\text { amendment to art. } 8 \\
\text { crime of Aggression }\end{array}$ & $\begin{array}{l}0.25 \\
1.25 \\
1.25 \\
1.25\end{array}$ & 4.00 \\
\hline Modifying (Dim 3) & $\begin{array}{l}\text { Rome Statute of the ICC } \\
\text { APIC } \\
\text { amendment to art. } 8\end{array}$ & $\begin{array}{l}1.00 \\
0.50 \\
0.50\end{array}$ & 2.00 \\
\hline IMPLEMENTING (Dim 4 ) & $\begin{array}{l}\text { cooperation (in progress/issued) } \\
\text { complementarity (in progress/issued) }\end{array}$ & $\begin{array}{l}0.50 \\
0.50\end{array}$ & 1.00 \\
\hline Triggering (Dim 5) & art. 14/art.12(a) Rome Statute & 1.00 & 1.00 \\
\hline
\end{tabular}

Table 48: Dimensions of the Index - Ratification as Strongest Factor

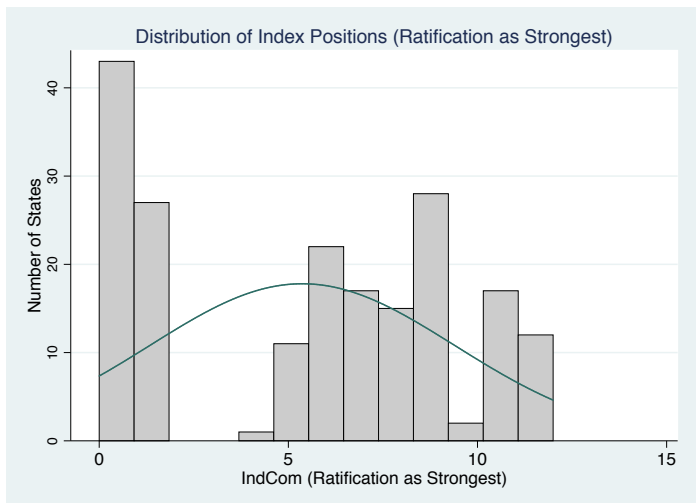

Figure 37: Frequency Distribution - Index (Ratification as Strongest Factor) 


\subsection{Index of Commitment to the ICC}

\begin{tabular}{|c|c|}
\hline Group 1 & COMPREHENSIVE COMMITMENT \\
\hline 12.00 & Estonia, Finland, Netherlands, Samoa, Slovenia, Trinidad and Tobago \\
\hline 11.50 & Croatia, Germany, Poland \\
\hline 11.00 & Georgia, Norway, Macedonia \\
\hline 10.50 & Austria, Belgium, Costa Rica, Cyprus, Iceland, Luxembourg, Uruguay \\
\hline 10.00 & Chile, Latvia, Lithuania, Malta, Slovakia, Spain, Switzerland \\
\hline Group 2 & SLIGHTLY CUSTOMIZED COMMITMENT \\
\hline 9.50 & $\begin{array}{l}\text { Bulgaria, Bosnia Herzegovina, Burkina Faso, Central African Republic, Czech Republic, } \\
\text { Denmark, Greece, Ireland, Liechtenstein, Mauritius, Montenegro, New Zealand, } \\
\text { Romania, Serbia, South Korea, Uganda }\end{array}$ \\
\hline 8.50 & Botswana, Panama, Senegal, Sweden \\
\hline 8.00 & Albania, France, Mali, United Kingdom of Great Britain \\
\hline GROUP 3 & MODERATEly Customized COMMitMENT \\
\hline 7.50 & $\begin{array}{l}\text { Andorra, Argentina, Benin, Brazil, Democratic Republic of the Congo, Ecuador, Gabon, } \\
\text { Hungary, Japan, Mexico, Palestine, Paraguay, South Africa }\end{array}$ \\
\hline 7.00 & Bolivia, Dominican Republic, El Salvador, Honduras, San Marino \\
\hline 6.50 & Belize, Canada, Cape Verde, Guyana, Italy, Kenya, Malawi, Namibia, Tunisia \\
\hline 6.00 & Australia, Colombia, Lesotho, Portugal, Timor Leste, \\
\hline GROUP 4: & StRONGLYLY CUSTOMIZED COMMITMENT \\
\hline 5.75 & Ghana, Mongolia, Peru, Sierra Leone \\
\hline 5.50 & Barbados, Comoros, Cook Islands, Liberia, Moldova, Philippines, Suriname, Vanuatu \\
\hline 5.25 & Jordan \\
\hline 5.00 & Bangladesh, Burundi, Cambodia, Fiji, Niger \\
\hline 4.75 & Madagascar, Tanzania, Venezuela \\
\hline 4.50 & $\begin{array}{l}\text { Afghanistan, Antigua and Barbuda, Dominica, Gambia, Grenada, Guatemala, } \\
\text { Ivory Coast, Maldives, Marshall Islands, Nauru, Nigeria, Republic of the Congo, } \\
\text { St. Kitts and Nevis, St. Lucia, Seychelles, St. Vincent and the Grenadines, Zambia }\end{array}$ \\
\hline GROUP 5: & WEAK COMMITMENT \\
\hline 3.75 & Guinea \\
\hline 3.50 & Chad, Djibouti, Tajikistan, Ukraine \\
\hline 2.00 & Armenia, Ethiopia, Nicaragua \\
\hline GROUP 6 & No OR Very Weak COMmitment \\
\hline 1.50 & Azerbaijan, Indonesia, Rwanda \\
\hline 1.00 & Angola, Guinea-Bissau, Malaysia, Mozambique \\
\hline 0.75 & Bahamas, Jamaica \\
\hline 0.50 & $\begin{array}{l}\text { Algeria, Bahrain, Cameroon, Egypt, Eritrea, Haiti, Iran, Kuwait, Kyrgyzstan, Lao PDR, } \\
\text { Monaco, Morocco, Myanmar, Oman, Russian Federation, Sao Tome and Principe, } \\
\text { Solomon Islands, Syrian Arabic Republic, Thailand, Turkey, UA Emirates, Uzbekistan, } \\
\text { Yemen, Zimbabwe }\end{array}$ \\
\hline 0.00 & $\begin{array}{l}\text { Belarus, Bhutan, Brunei, China, Cuba, Equatorial Guinea, India, } \\
\text { Iraq, Israel, Kazakhstan, Kiribati, Lebanon, Libya, Mauritania, Micronesia, Nepal, } \\
\text { North Korea, Pakistan, Palau, Papua New Guinea, Qatar, Saudi Arabia, Singapore, } \\
\text { Somalia, South Sudan, Sri Lanka, Sudan, Swaziland, Togo, Tonga, Turkmenistan, Tuvalu, } \\
\text { United States of America, Vietnam }\end{array}$ \\
\hline
\end{tabular}




\subsection{Correlation Matrix - Dependent and Independent Variables}

\begin{tabular}{|c|c|c|c|c|c|c|c|c|c|c|c|c|c|c|c|c|c|}
\hline var. & INDEX & RAT & FH & ICJ & HL & GL & HR & CoN & UNPK & Ам & ICT & CPow & BIA & CrvL & ComL & $P_{A R}$ & Pres \\
\hline INDEXX & 1.000 & & & & & & & & & & & & & & & & \\
\hline RAT & 0.866 & 1.000 & & & & & & & & & & & & & & & \\
\hline $\mathrm{FH}$ & 0.612 & 0.534 & 1.000 & & & & & & & & & & & & & & \\
\hline ICJ & 0.403 & 0.359 & 0.284 & 1.000 & & & & & & & & & & & & & \\
\hline $\mathrm{HL}$ & 0.632 & 0.488 & 0.443 & 0.354 & 1.000 & & & & & & & & & & & & \\
\hline GL & 0.659 & 0.547 & 0.413 & 0.345 & 0.727 & 1.000 & & & & & & & & & & & \\
\hline HR & 0.567 & 0.465 & 0.259 & 0.261 & 0.703 & 0.524 & 1.000 & & & & & & & & & & \\
\hline Con & -0.257 & -0.254 & -0.249 & 0.010 & -0.138 & -0.346 & -0.129 & 1.000 & & & & & & & & & \\
\hline UNPK & 0.048 & 0.087 & -0.023 & -0.027 & -0.015 & 0.047 & 0.088 & -0.025 & 1.000 & & & & & & & & \\
\hline AM & -0.205 & -0.169 & -0.406 & -0.093 & -0.118 & -0.280 & 0.088 & 0.469 & 0.024 & 1.000 & & & & & & & \\
\hline ICT & 0.159 & 0.095 & 0.004 & -0.049 & 0.120 & 0.131 & 0.126 & -0.057 & 0.074 & 0.094 & 1.000 & & & & & & \\
\hline CPow & 0.159 & 0.101 & 0.266 & 0.220 & 0.283 & 0.198 & 0.211 & 0.016 & -0.065 & -0.114 & -0.071 & 1.000 & & & & & \\
\hline BIA & -0.405 & -0.315 & -0.346 & -0.185 & -0.341 & -0.296 & -0.257 & 0.181 & 0.041 & 0.197 & 0.007 & -0.288 & 1.000 & & & & \\
\hline CivL & 0.348 & 0.184 & 0.113 & 0.117 & 0.488 & 0.396 & 0.521 & -0.123 & -0.076 & -0.006 & 0.073 & 0.182 & -0.235 & 1.000 & & & \\
\hline CомL & -0.131 & -0.029 & 0.191 & -0.031 & -0.198 & -0.140 & -0.327 & 0.121 & 0.063 & -0.136 & -0.105 & 0.036 & 0.017 & -0.418 & 1.000 & & \\
\hline $\mathrm{P}_{\mathrm{AR}}$ & 0.369 & 0.278 & 0.484 & 0.152 & 0.294 & 0.248 & 0.169 & -0.061 & -0.045 & -0.197 & 0.160 & 0.256 & -0.113 & 0.057 & 0.178 & 1.000 & \\
\hline Pres & -0.153 & -0.023 & -0.315 & -0.043 & -0.197 & -0.149 & 0.037 & 0.119 & 0.106 & 0.306 & -0.107 & -0.194 & 0.109 & -0.064 & -0.141 & -0.794 & 1.000 \\
\hline
\end{tabular}

Table 49: Cross-Correlation Table (All Variables) 


\subsection{Regression Analyses with Civil Law and Presidential System}

Multiple Linear Regression Explaining Index Positions (Civil Law \& Presidential System)

\begin{tabular}{|c|c|c|c|c|c|c|c|c|c|}
\hline $\begin{array}{l}\text { STATES' Position on the } \\
\text { INDEX OF CoMmitment } \\
\text { TO THE ICC }\end{array}$ & $\begin{array}{l}\text { Model 1a } \\
\text { Credibility }\end{array}$ & $\begin{array}{l}\text { Model 2a } \\
\text { Monitoring }\end{array}$ & $\begin{array}{l}\text { Model 3a } \\
\text { Credibility } \\
\text { \& Monitoring }\end{array}$ & $\begin{array}{c}\text { Model 4a } \\
\text { Arm. Con. \& } \\
\text { Peacekeeping }\end{array}$ & $\begin{array}{c}\text { Model 5a } \\
\text { Transitional } \\
\text { Justice }\end{array}$ & $\begin{array}{c}\text { Model 6a } \\
\text { Hegemonic } \\
\text { Power }\end{array}$ & $\begin{array}{c}\text { Model 7A } \\
\text { Legal \& } \\
\text { Gov. System }\end{array}$ & $\begin{array}{l}\text { Model 8A } \\
\text { Control } \\
\text { Only }\end{array}$ & $\begin{array}{c}\text { Model 9A } \\
\text { Full } \\
\text { Model }\end{array}$ \\
\hline \multicolumn{10}{|c|}{ Explanatory Variables } \\
\hline Humanttarian Law & $\begin{array}{l}0.381 * * * \\
(0.0338)\end{array}$ & $\begin{array}{l}- \\
-\end{array}$ & $\begin{array}{l}0.245 * * * \\
(0.0338)\end{array}$ & $\begin{array}{l}0.241 * * * \\
(0.0334)\end{array}$ & $\begin{array}{l}0.232 * * * \\
(0.0339)\end{array}$ & $\begin{array}{l}0.239 * * * \\
(0.0338)\end{array}$ & $\begin{array}{l}0.209 * * * \\
(0.0384)\end{array}$ & $\begin{array}{l}- \\
-\end{array}$ & $\begin{array}{l}0.189^{* * *} \\
(0.0376)\end{array}$ \\
\hline Political Freedom & $\begin{array}{l}- \\
-\end{array}$ & $\begin{array}{c}1.047 * * * \\
(0.110)\end{array}$ & $\begin{array}{l}0.754^{* * *} \\
(0.106)\end{array}$ & $\begin{array}{l}0.702^{* * *} \\
(0.107)\end{array}$ & $\begin{array}{c}0.769 * * * \\
(0.114)\end{array}$ & $\begin{array}{c}0.725^{* * *} \\
(0.106)\end{array}$ & $\begin{array}{c}0.817^{* * *} \\
(0.109)\end{array}$ & - & $\begin{array}{c}0.781^{* * *} \\
(0.114)\end{array}$ \\
\hline Comp. JuRisdiction ICJ & $\begin{array}{l}- \\
-\end{array}$ & $\begin{array}{c}2.014^{* * * *} \\
(0.461)\end{array}$ & $\begin{array}{c}1.200^{* * * *} \\
(0.424)\end{array}$ & $\begin{array}{c}1.306^{* * *} \\
(0.420)\end{array}$ & $\begin{array}{c}1.293 * * * \\
(0.421)\end{array}$ & $\begin{array}{c}1.274 * * * \\
(0.415)\end{array}$ & $\begin{array}{c}1.207 * * * \\
(0.421)\end{array}$ & $\begin{array}{l}- \\
-\end{array}$ & $\begin{array}{c}1.441^{* * * *} \\
(0.409)\end{array}$ \\
\hline \multicolumn{10}{|l|}{ Control Variables } \\
\hline \multirow{2}{*}{ YeARS of Arm. Conflicts } & - & - & - & $-0.0543^{* *}$ & - & - & - & -0.0566 & $-0.0470^{*}$ \\
\hline & - & - & - & $(0.0242)$ & - & - & - & $(0.0350)$ & $(0.0261)$ \\
\hline \multirow[t]{2}{*}{ UNPK TRoops/Mí. НАв. } & - & - & - & 0.00338 & - & - & - & 0.00402 & 0.00302 \\
\hline & - & - & - & $(0.00252)$ & - & - & - & $(0.00331)$ & $(0.00245)$ \\
\hline \multirow[t]{2}{*}{ NuMBer of AMNESTIES } & - & - & - & - & 0.00934 & - & - & -0.148 & 0.0808 \\
\hline & - & - & - & - & $(0.0914)$ & - & - & $(0.130)$ & $(0.0998)$ \\
\hline \multirow[t]{2}{*}{ Int. Criminal Tribunals } & - & - & - & - & $1.988 * *$ & - & - & $2.256 * *$ & $1.759^{* *}$ \\
\hline & - & - & - & - & $(0.821)$ & - & - & $(1.075)$ & $(0.802)$ \\
\hline \multirow[t]{2}{*}{ Form COLONIAL Power } & - & - & - & - & - & $-1.907^{* *}$ & - & 0.335 & $-1.556^{* *}$ \\
\hline & - & - & - & - & - & $(0.742)$ & - & $(0.974)$ & $(0.739)$ \\
\hline \multirow[t]{2}{*}{ BIA WтTн тнЕ USA } & - & - & - & - & - & $-1.286 * * *$ & - & $-2.589^{* * *}$ & $-1.135^{* *}$ \\
\hline & - & - & - & - & - & $(0.453)$ & - & $(0.582)$ & $(0.447)$ \\
\hline \multirow{2}{*}{ CiviL LaW SYSTem } & - & - & - & - & - & - & $0.918 * *$ & $1.958^{* * *}$ & $0.821 *$ \\
\hline & - & - & - & - & - & - & $(0.433)$ & $(0.508)$ & $(0.422)$ \\
\hline \multirow[t]{2}{*}{ Presidential System } & - & - & - & - & - & - & 0.495 & -0.429 & 0.368 \\
\hline & - & - & - & - & - & - & $(0.405)$ & $(0.537)$ & $(0.407)$ \\
\hline Constant & $\begin{array}{l}-0.850 \\
(0.552)\end{array}$ & $\begin{array}{l}-0.743 \\
(0.536)\end{array}$ & $\begin{array}{l}-2.759 * * * \\
(0.551)\end{array}$ & $\begin{array}{l}-2.409 * * * \\
(0.584)\end{array}$ & $\begin{array}{l}-2.802 * * * \\
(0.635)\end{array}$ & $\begin{array}{l}-1.493^{*} \\
(0.760)\end{array}$ & $\begin{array}{l}-3.155 * * * \\
(0.635)\end{array}$ & $\begin{array}{l}6.101^{* * *} \\
(0.623)\end{array}$ & $\begin{array}{c}-1.913^{* *} \\
(0.834)\end{array}$ \\
\hline Observations & 193 & 193 & 193 & 193 & 193 & 193 & 193 & 193 & 193 \\
\hline$R$-squared & 0.400 & 0.432 & 0.556 & 0.572 & 0.570 & 0.584 & 0.570 & 0.293 & 0.618 \\
\hline Adj. R-squared & 0.397 & 0.426 & 0.549 & 0.561 & 0.558 & 0.573 & 0.558 & 0.262 & 0.595 \\
\hline
\end{tabular}

Standard errors in parentheses
$* * * \mathrm{p}<0.01, * * \mathrm{p}<0.05, * \mathrm{p}<0.1$ 
Multiple Logistic Regression Explaining Ratification (Civil Law \& Presidential System)

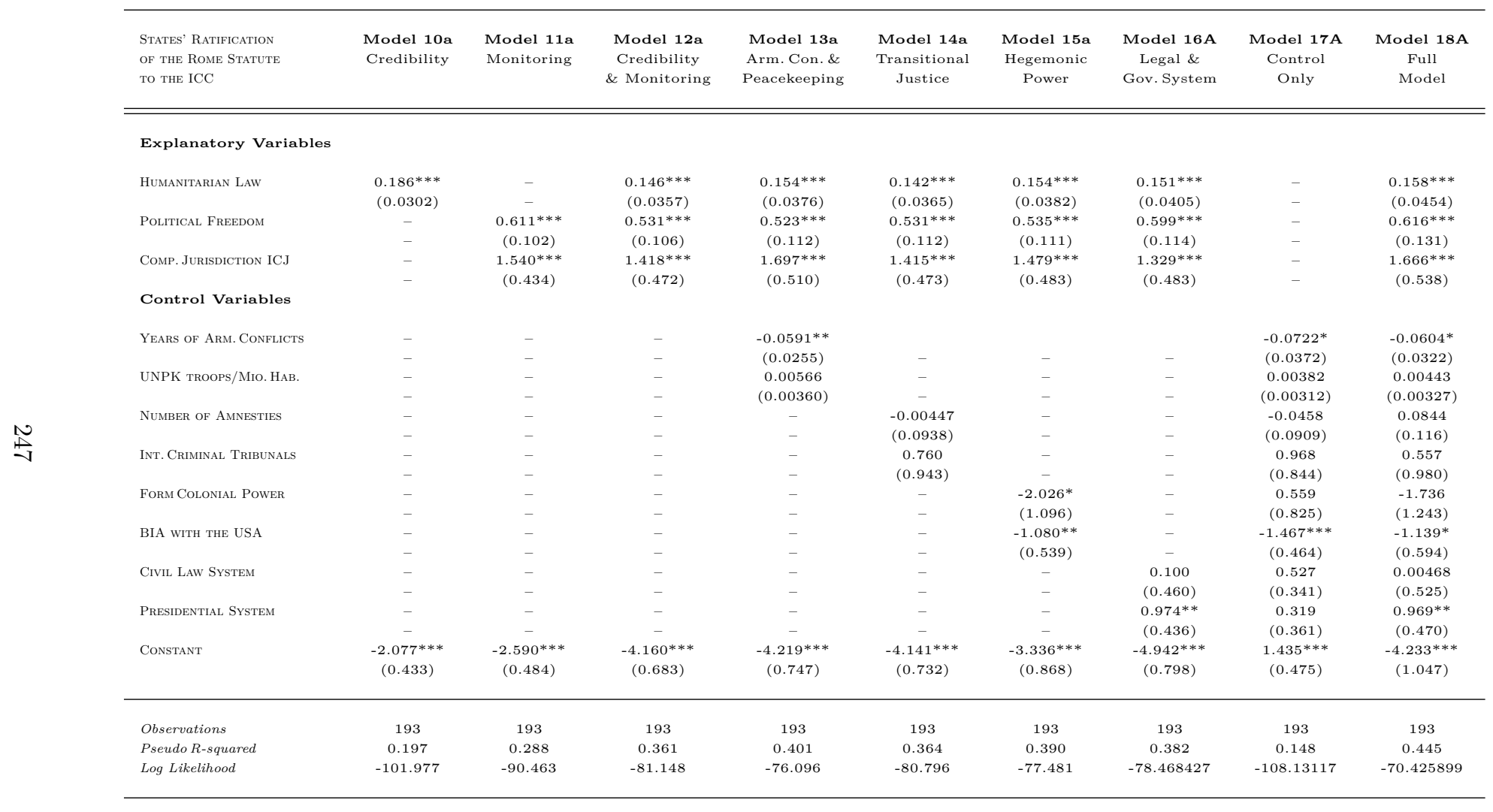

Standard errors in parentheses 


\subsection{Database \& Codebook I: Index of Commitment (DV)}

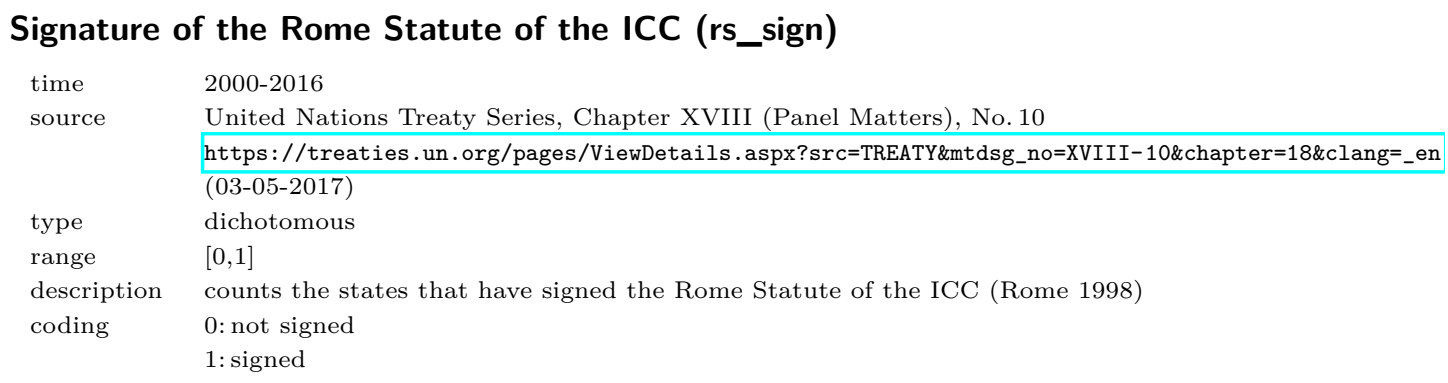

\section{Ratification of the Rome Statute of the ICC (rs_rat)}

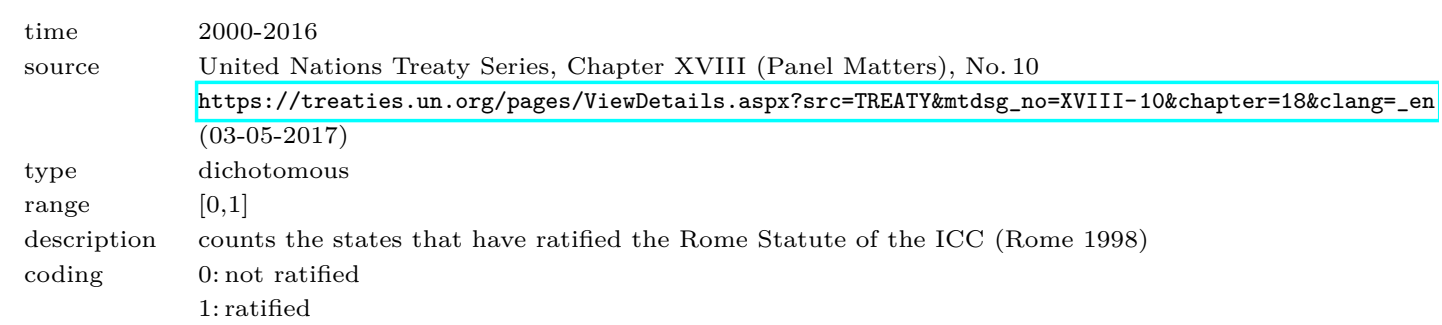

\section{Signature of the Agreement on Privileges and Immunities (apic_sign)}

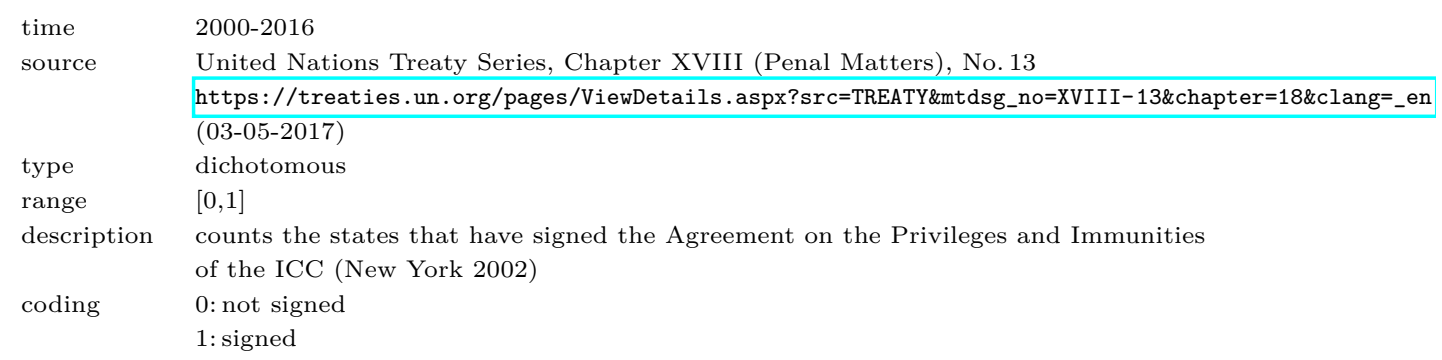

\section{Ratification of the Agreement on Privileges and Immunities (apic_rat)}

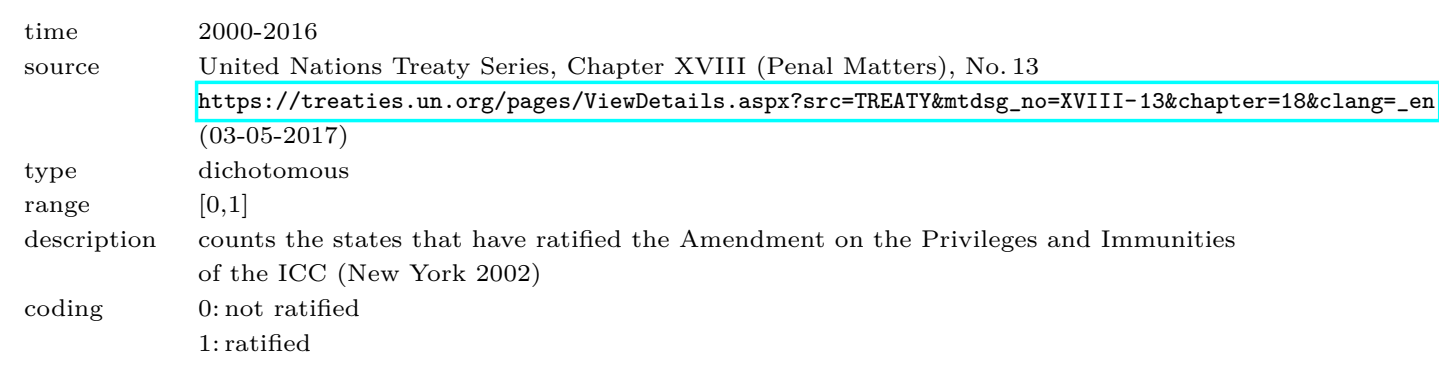




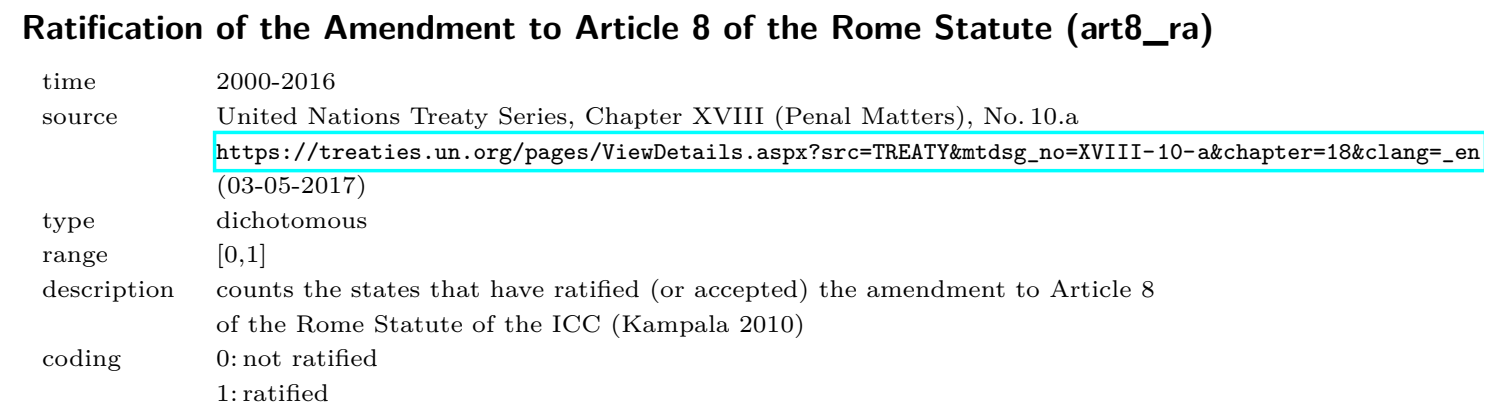

\section{Ratification of the Amendments on the Crime of Aggression (coa_ra)}

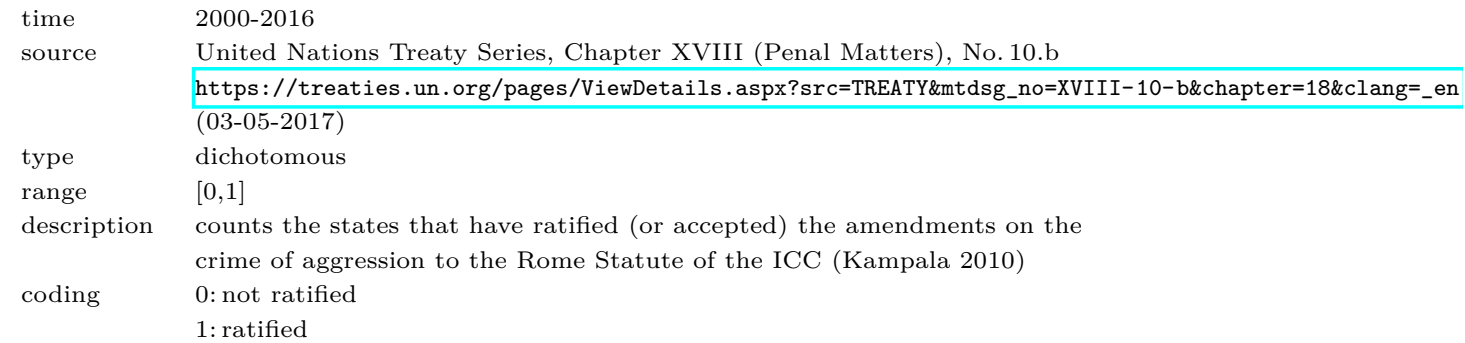

\section{Reservations or Interpretative Declarations to the Rome Statute (rs_sov_dec)}

$\begin{array}{ll}\text { time } & \text { 2000-2016 } \\ \text { source } & \text { United Nations Treaty Series, Chapter XVIII (Panel Matters), No. } 10 \\ & \text { https://treaties.un.org/pages/ViewDetails . aspx?src=TREATY\&mtdsg_no=XVIII-10\&chapter=18\&clang=_en } \\ & \text { (03-05-2017) } \\ \text { type } & \text { dichotomous } \\ \text { range } & {[0,1]} \\ \text { description } & \text { counts the states that have made reservations or interpretative declarations } \\ & \text { to the Rome Statute of the ICC (Rome 1998) that protect their sovereignty } \\ \text { coding } & \text { 0: no reservation or interpretative declaration } \\ & \text { 1: reservation and/or interpretative declaration, that protects the state from the ICC } \\ & \text { (e.g.transitional provision, maintaining reprieves or amnesties, interpreting humanitarian law } \\ & \text { or core crimes, stressing self-defense and principle of complementarity) }\end{array}$




\section{Reservations or Interpretative Declarations to the APIC (apic_sov_dec) \\ time 2000-2016 \\ source United Nations Treaty Series, Chapter XVIII (Penal Matters), No. 13 \\ https://treaties.un.org/pages/ViewDetails.aspx?src=TREATY\&mtdsg_no=XVIII-13\&chapter=18\&clang=_en \\ (03-05-2017) \\ type dichotomous \\ range $\quad[0,1]$ \\ description counts the states that have made reservations or interpretative declarations to the \\ Amendment on the Privileges and Immunities of the ICC (New York 2002) that protects their sovereignty \\ coding $\quad 0$ : no reservation or interpretative declaration \\ 1: reservation and/or interpretative declaration, that protects the state from the ICC \\ (e.g. restriction of immunity or stressing territorial boarders)}

\section{Implementing Norms on Complementarity (imp_comp)}

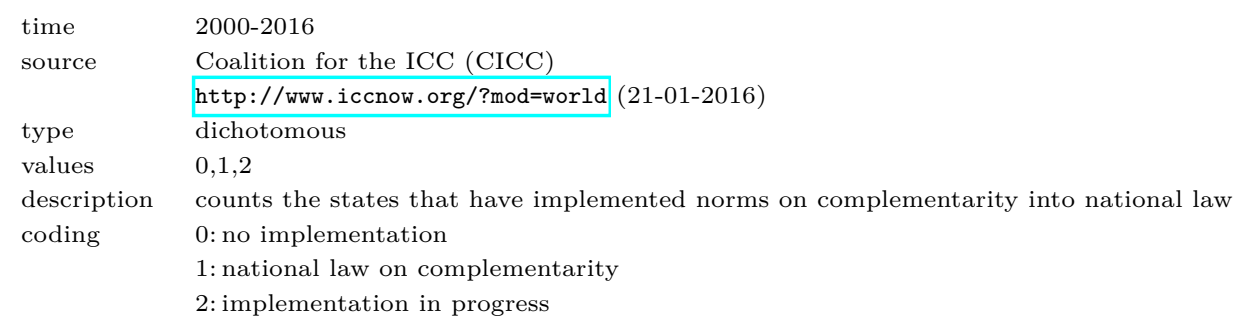

\section{Implementing Norms on Cooperation (imp_coop)}

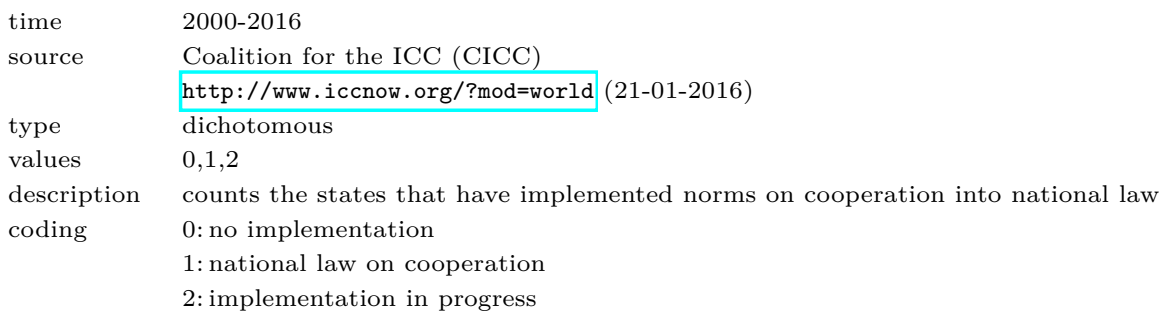

\section{Triggering Investigations and Prosecutions of the ICC (icc_act_ini)}

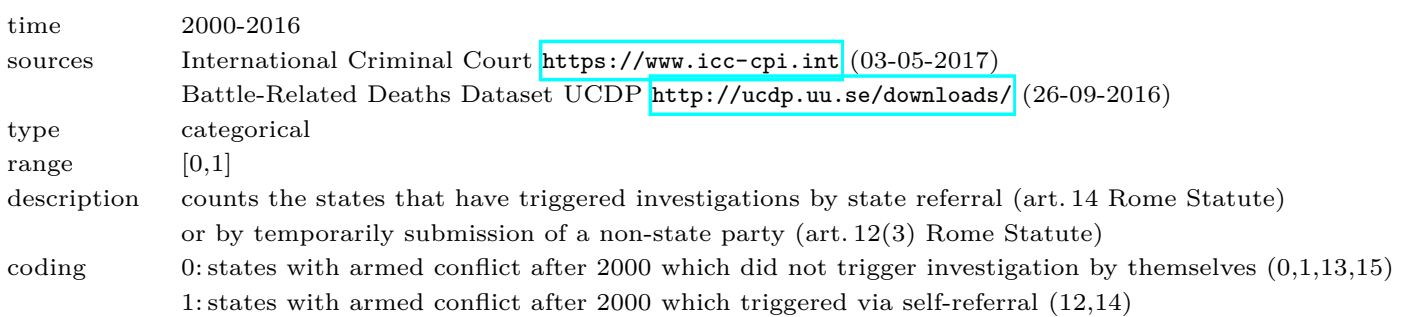




\subsection{Database \& Codebook II: Determinants of Commitment (IV)}

\section{Armed Conflicts, Number and Length (Loclnc_15)}

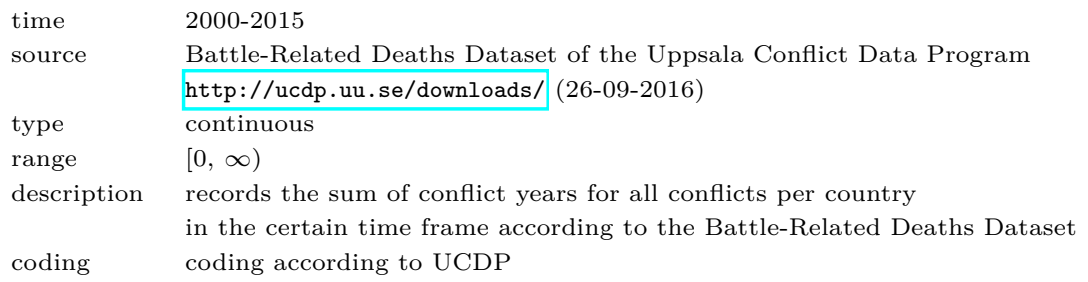

\section{Compulsory Jurisdiction International Court of Justice (ComJur_ICJ)}

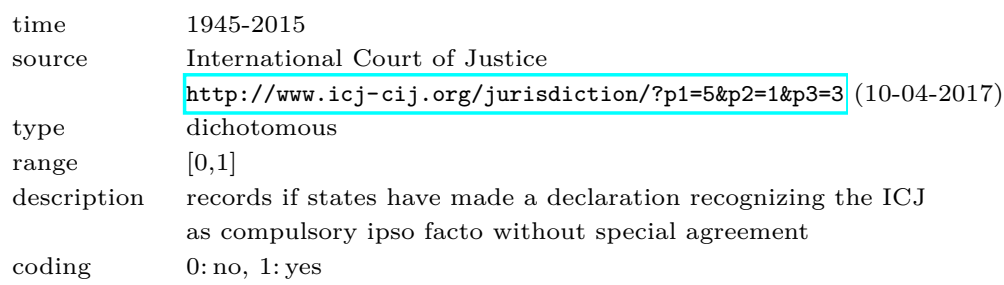

\section{Humanitarian Law Commitment (HumLaw)}

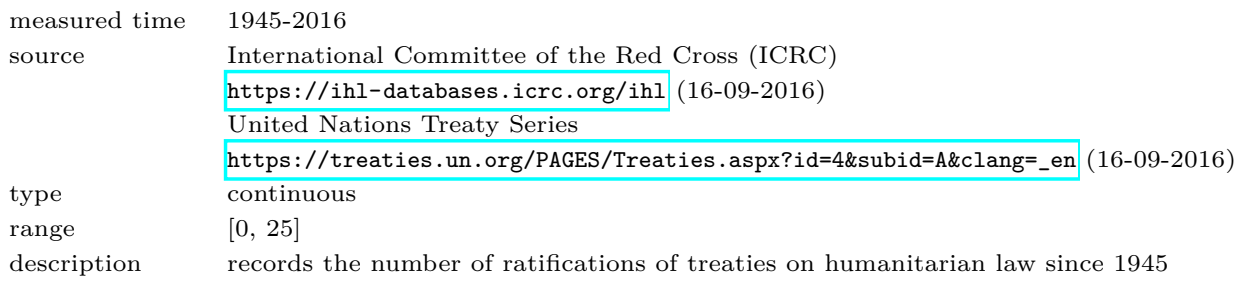




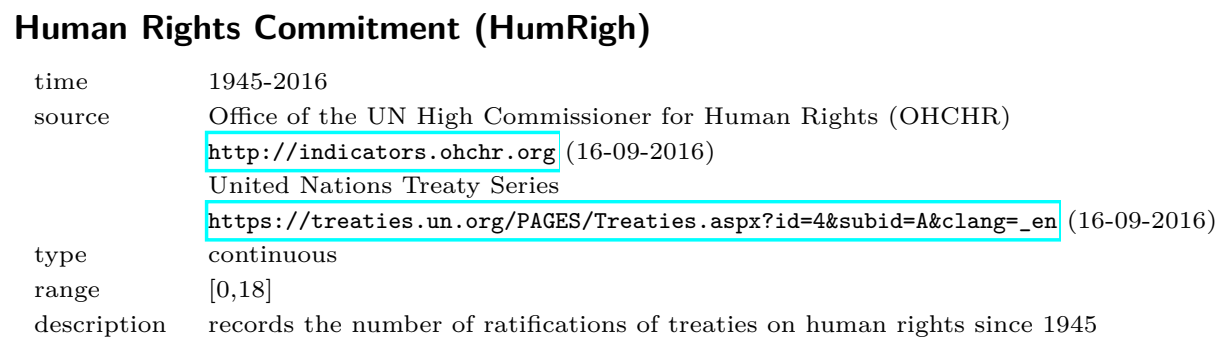

\section{Number of Amnesties (TJ_Amnesty)}

$\begin{array}{ll}\text { time } & 1990-2010 \\ \text { source } & \text { Transitional Justice Database (TJDB) } \\ & \text { http://www.tjdbproject.com/ }(26-09-2016) \\ \text { type } & \text { continuous } \\ \text { range } & {[0, \infty)} \\ \text { description } & \text { records the number of amnesties }\end{array}$

\section{International Criminal Tribunals (TJ_IntC)}

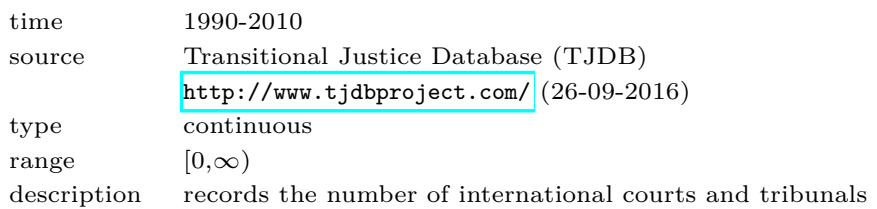

\section{Colonial Power (ColPow)}

time

$1800-2015$

source CIA World Fact Book

https://www.cia.gov/library/publications/the-world-factbook/fields/2028.html\#af (24-04-17)

type dichotomous

range $\quad[0,1]$

description measures if a state was a colonial power

coding 0 : no, 1 : yes 


\section{Common Law (commlaw)}

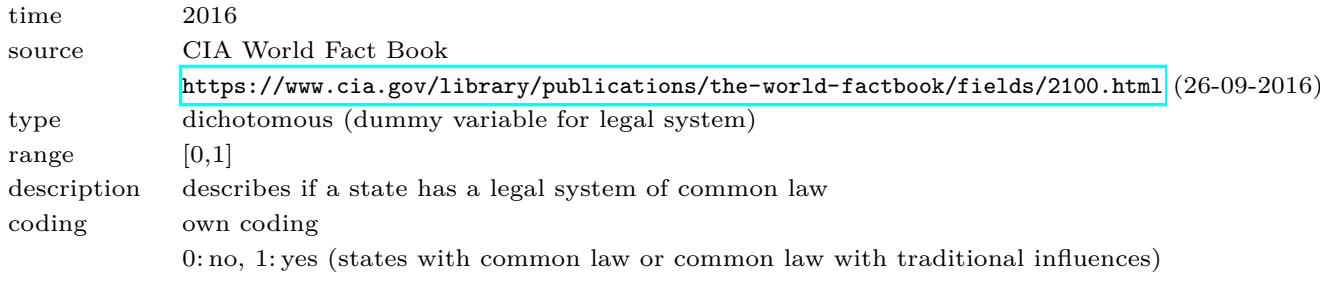

\section{Civil Law (civlaw)}

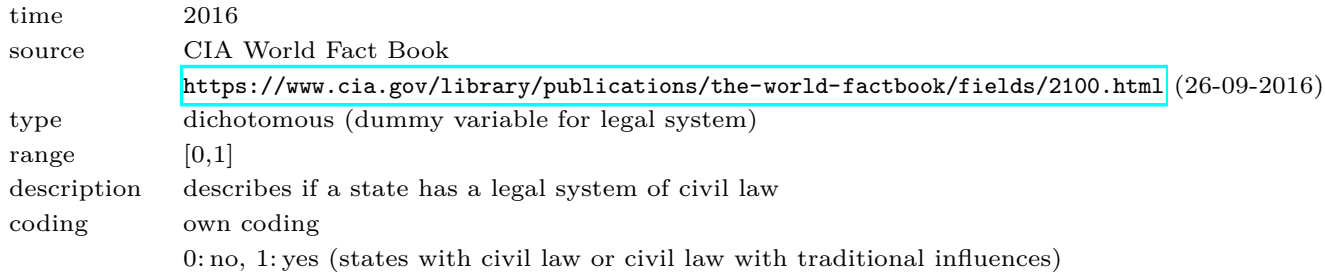

\section{Parliamentary System (parl)}

$\begin{array}{ll}\text { time } & 2016 \\ \text { source } & \text { CIA World Fact Book } \\ & \text { https://www.cia.gov/library/publications/the-world-factbook/f } \\ \text { type } & \text { dichotomous (dummy-variable for governmental system) } \\ \text { range } & {[0,1]} \\ \text { description } & \text { records if the governmental system of a state is parliamentary } \\ \text { coding } & \text { own coding } \\ & 0: \text { no, 1:yes (parliamentary republic, parliamentary monarchy) }\end{array}$

\section{Presidential System (pres)}

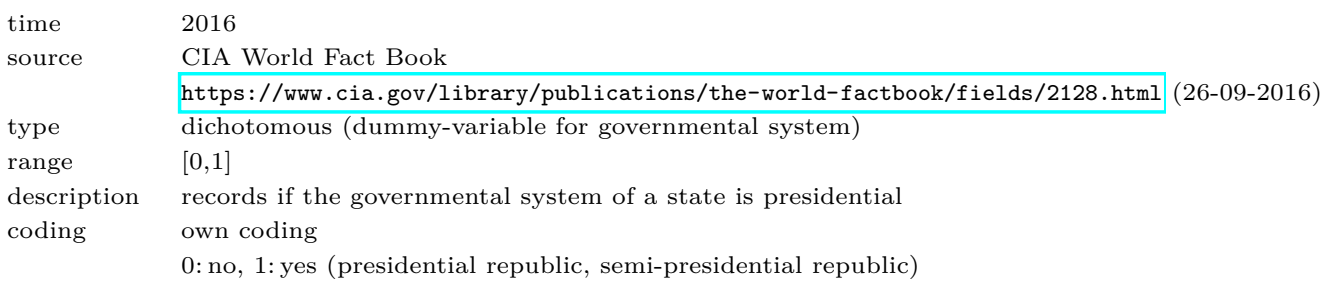




\section{U.S. Bilateral Non-Surrender Agreement (BIA_USA)}

$\begin{array}{ll}\text { time } & 2015 \\ \text { source } & \text { Country reports of the Coalition for the ICC (CICC) } \\ & \text { http://www.iccnow.org/?mod=world }(30-09-2016) \\ \text { type } & \text { dichotomous } \\ \text { range } & {[0,1]} \\ \text { description } & \text { records if a state has signed a Bilateral Non-Surrender Agreement withe the USA } \\ \text { coding } & 0: \text { no, } 1 \text { : yes }\end{array}$




\section{References}

Abbott, Kenneth W. (1989): Modern International Relations Theory. A Prospectus fot International Lawyers, in: Yale Journal of International Law, 14, 335-411.

Abbott, Kenneth W./Snidal, Duncan (2000): Hard Law and Soft Law in International Governance, in: International Organization, 54, No. 3, 421-456.

Abbott, Kenneth W./Keohane, Robert O./Moravcsik, Andrew/Slaughter, AnneMarie/Snidal, Duncan (2000): The Concept of Legalization, in: International Organization, 54, No. 3, 401-419.

Akande, Dapo/Tzanakopoulos, Antonios (2017): The Crime od Aggression in the ICC and State Responsibility, in: Harvard International Law Journal, 58, 33-36.

Akhavan, Payam (1998): Justice in the Hague. Peace in Former Yugoslavia, in: Human Rights Quarterly, 20, No. 4, 737-816.

- (2009): Are International Criminal Tribunals a Disincentive to Peace? Reconciling Judicial Romanticism with Political Realism, in: Human Rights Quarterly, 31, No. 3, 624-654.

- (2012): Reducing Genocide to Law. Definition, Meaning, and the Ultimate Crime, Cambridge et al.: Cambridge University Press.

Aksar, Yusuf (2005): Implementing International Humanitarian Law: From the Ad Hoc Tribunals to a Permanent International Criminal Court, London: Routledge.

Allott, Philip (1996): The International Court and the Voice of Justice, in: Lowe, Vaughan/Fitzmaurice, Malgoisa (Eds.): Fifty Years of the International Court of Justice. Essays in Honour of Sir Robert Jennings., Cambridge: Cambridge University Press, 17-39.

Alter, Karen J. (2000): The European Union's Legal System and Domestic Policy: Spillover or Backlash?, in: International Organization, 54, No. 3, 489-518.

- (2004): Agents or Trustees? International Courts in their Political Context, University of Bremen, Collaborative Research Center 597.

- (2006): Delegation to International Courts and the Limits of Recontracting Power, in: Hawkins, Daren/Lake, David A./Nielson, Daniel L./Tierney, Michale J. (Eds.): 
Delegation and Agency in International Organizations, Chapter 11, Cambridge: Cambridge University Press, 312-338.

- (2008): Delegating to International Courts: Self-Binding Versus Other-Binding Delegation, in: Journal of Law and Contemporary Problems, 71, No. 37, 37-76.

- (2011): The Evolving International Judiciary, Buffett Center for International and Comparative Studies Working Paper Series, 11/002.

- (2012c): The Multiple Roles of International Courts and Tribunals: Enforcement, Dispute Settlement. Constitutional and Administrative Review, Northwestern University School of Law, Faculty Working Papers, 212.

- (2014): The New Terrain of International Law: Courts, Politics, Rights., Princeton: Princton University Press.

Alter, Karen J./Helfer, Laurence R./Saldias, Osvaldo (2012): Transplanting the European Court of Justice. The Experience of the Andean Tribunal of Justice, in: The American Journal of Comparative Law, 60, 629-664.

Ambos, Kai (2010): Das Verbrechen der Agression nach Kampala, in: Zeitschrift für Internationale Strafrechtsdogmatik, 11, 649-668.

- (2011): Internationales Strafrecht: Strafanwendungsrecht, Völkerstrafrecht, Europäisches Strafrecht, Rechtshilfe, München: C.H. Beck.

Amerasinghe, Chittharanjan (2002): Jurisdiction of International Tribunals, The Hague, London, New York: Kluwer Law International.

Appel, Benjamin J. (2018): In the Shadow of the International Criminal Court: Does the ICC Deter Human Rights Violations?, in: Journal of Conflict Resolution, 62, No. $1,3-28$.

Arendt, Hannah (1963): Eichmann in Jerusalem, New York: The Viking Press.

Arsanjani, Manoush H. (1999): The Rome Statute of the International Criminal Court, in: American Journal of International Law, 93, No. 1, 22-43.

Axelrod, Robert (1980): Effective Choice in the Prisoner's Dilemma, in: Journal of Conflict Resolution, 24, No. 1, 3-25.

- (1984): The Evolution of Cooperation, New York: Basic Books. 
Barkan, Elazar/Karn, Alexander (2006): Taking Wrongs Seriously. Apologies and Reconciliation, Stanford: Stanford University Press.

Barriga, Stefan (2010): Der Kompromiss von Kampala zum Verbrechen der Aggression. Ein Blick aus Verhandlungsperspektive, in: Zeitschrift für Internationale Strafrechtsdogmatik, 11, 644-648.

Barriga, Stefan/Grover, Leena (2011): A Historic Breakthrough on the Crime of Aggression, in: The American Journal of International Law, 105, No. 3, 517-533.

Barsalou, Judy/Baxter, Victoria (2007): The Urge to Remember. The Role of Memorials in Social Reconstruction and Transitional Justice, in: Stabilization and Reconstruction Series.

Bellinger, John B. (2006): Introductory Remarks, in: George Washington International Law Review, 38, No. 3, 506-507.

Bellinger, John B./Padmanabhan, Vijay M. (2011): Detention Operations in Contemporary Conflicts: Four Challenges for the Geneva Conventions and Other Existing Law, in: American Journal of International Law, 105, No. 2, 201-243.

Bensouda, Fatou (2014): We Should at all Costs Prevent the ICC from Being Politicized. Interview mit fatou Bensouda, Chief Prosecutor of the International Criminal Court, in: German Review on the United Nations, 62, No. 1, 1-8.

Berman, Paul Schiff (2007): Global Legal Pluralism, in: Southern California Law Review, 80, 1155-1238.

Boed, Roman (1998): An Evaluation of the Legality and Efficacy of Lustration as a Tool of Transitional Justice, in: Columbia Journal of Transnational Law, 37, No. 2, 357-402.

Booth, James W. (2001): The Unforgotten. Memories of Justice, in: The American Political Science Review, 95, No. 4, 777-791.

Broomhall, Bruce (1999): The International Criminal Court: Overview and Cooperation with States, in: Penales, Association Internationale De Droit (Ed.): ICC Ratification and National Implementing Legislation, Nouvelles Études Pénales, volume 13, Chapter 2, Paris: Érès, 45-111.

Brown, Bartram S. (1999): U.S. Objections to the Statute of the International Criminal Court. A Brief Response, in: International Law and Politics, 31, 855-891. 
Buneo De Mesquita, Bruce/Downs, George W./Smith, Alastair/Cherif, Feryal M. (2005): Thinking Inside the Box. A Closer Look at Democracy and Human Rights, in: International Studies Quarterly, 49, 439-457.

Carruba, Clifford J./Gabel, Matthew/Hankla, Charles (2008): Judicial Behavior und Political Constraints. Evidence from the European Court of Justice, in: The American Political Science Review, 102, No. 4, 435-452.

Carruba, Clifford J.; Matthew Gabel ; Charles Hankla (2012): Understanding the Role of the European Court of Justice in European Integration, in: American Political Science Review, 106, No. 1, 214-223.

Cassese, Antonio (1998): On the Current Trends Towards Criminal Prosecution and Punishment of Breaches of International Humanitarian Law, in: European Journal of International Law, 9, 2-17.

- (2006): Is the ICC Still Having Teething Problems, in: Journal of International Criminal Justice, 4, 434-441.

Chapman, Terrence/Chaudoin, Stephen (2013): Ratification Patterns and the International Criminal Court, in: International Studies Quarterly, 57, 400-409.

Chayes, Abram/Chayes, Antonia Handler (1993): On Compliance, in: International Organization, 47, No. 2, 175-205.

Clark, Anne Marie (2001): Diplomacy of Conscience. Amnesty International and Changing Human Rights Norms, Princton University Press.

Clark, Roger S. (2007): Nuremberg and the Crimes Against Peace, in: Washington University Global Studies Law Review, 6, No. 3, 527-550.

- (2010): Amendments to the Rome Statute of the International Criminal Court Considered at the first Review Conference on the Court, in: Goettingen Journal of International Law, 2, No. 2, 689-711.

Clinton, Bill (1996): A Commitment to Human Dignity, Democracy, and Peace, in: Electronic Journal of the U.S. Information Agency on Confronting Human Rights Violations, 1, No. 3, 10-15.

- (2000): Statement on Signature of the International Criminal Court Treaty, http://www.iccnow.org/documents/USClintonSigning31Dec00.pdf. 
Cobban, Helena (2006): Think Again. International Courts, in: Foreign Policy, 153, $22-28$.

- (2007): Amnesty after Atrocity? Healing Nations after Genocide and War Crimes., London and New York: Routledge.

Cohen, Harlan G. (2009): Can International Law Work? A Constructivist Expansion, Digital Commons at University of Georgia Law, Scholary Works, 747.

Cowell, Frederick (2014): Defensive Relativism. Universalism, Sovereignty, and the Postcolonial Predictment, in: Dhawan, Nikita (Ed.): Decolonizing Enlightenment. Transnational Justice, Human Rights and Democracy in a Postcolonial World., Opladen et al.: Barbara Budrich, 261-275.

Cox, D.R. (1958): The Regression Analysis of Binary Sequences, in: Journal of the Royal Statistical Society, 20, No. 2, 215-242.

Cronin-Furman, Kate (2013): Managing Expectations. International Criminal Trials and the Prospect of Deterrence of Mass Atrocity, in: International Journal of Transitional Justice, 7, No. 3, 434-454.

Dancy, Georff (2017): Searching for Deterrence at the International Criminal Court, in: International Criminal Law Review, 17, No. 4.

Dancy, Georff/Montal, Florencia (2017): From Law Versus Politics To Law In Politics: A Pragmatist Assessment Of The ICC's Impact, in: American University International Law Review, 32, No. 3, 645-705.

Danner, Allison (2006): When Courts Make Law: How the International Criminal Tribunals Recast the Laws of War, in: Vanderbilt Law Review, 59, No. 1, 1-65.

David, Roman (2003): Lustration Law in Actions. The Motives and the Evaluation of the Lustration Policy in the Czech Republic and Poland, in: Law and Social Inquiry, 28, No. 2, 387-439.

DeGreiff, Pablo (2006): Handbook of Reparations, Oxford: Oxford University Press.

Deitelhoff, Nicole (2002): Angst vor Bindung? Das ambivalente Verhältnis von Demokratien zum Internationalen Strafgerichtshof, HSFK Standpunkte, Nr. 5.

- (2006): Überzeugung in der Politik. Grundzüge einer Diskurstheorie Internationalen Regierens, Frankfurt am Main: Suhrkamp. 
- (2009): The Discursive Process of Legalization: Charting Islands of Persuasion in the ICC Case, in: International Organization, 63, No. 1, 33-65.

Deitelhoff, Nicole/Zürn, Michael (2016): Per Anhalter durch die IB-Galaxis. Lehrbuch dr Internationalen Beziehungen, München: C.H. Beck.

Dhawan, Nikita (Ed.) (2014): Decolonizing Enlightenment. Transnational Justice, Human Rights and Democracy in a Postcolonial World, Opladen et al.: Barbara Budrich.

Dickinson, G. Lowes (1926): The International Anarchy. 1904-1914, United States: University Press of the Pacific.

Diez, Thomas/Bode, Ingvild/DaCosta, Aleksandra F. (2011): Key Concepts in International Relations, Los Angeles et al.: Sage.

Donnelly, Jack (1986): International Human Rights. A Regime Analysis, in: International Organization, 40, No. 3, 599-642.

Dörmann, Knut (2003): War Crimes under the Rome Statute of the International Criminal Court with a Special Focus on the Negotiations on the Elements of Crimes, in: Bogdandy, Armin von/Wolfrum, Rüdiger (Eds.): Max Planck Yearbook of United Nations Law, volume 7, Leiden: Brill, 341-407.

Downs, Georg W./Jones, Michael A. (2002): Reputation, Compliance, and International Law, in: Journal of Legal Studies, 31.

Doyle, Michael W.;/Carlson, Geoffrey S. (2008): Silence of the Laws? Conceptions of International Relations and International Law in Hobbes, Kant, and Locke, in: Columbia Journal of Transnational Law, 46, 648-666.

Drumbl, Mark A. (2007): Atrocity, Punishment, and International LAw, Cambridge: Cambridge University Press.

Dunoff, Jeffrey L./Pollack, Mark A. (2013): Interdisciplinary Perspectives on International Law and International Relations. The State of the Art, Cambridge: Cambridge University Press.

Dutton, Yvonne (2011): Explaining State Commitment to the International Criminal Court. Strong Enforcement Mechanisms as Credible Threat, in: Washington University Global Studies Law Review, 10, 477-533. 
Egle, Julia (2016): Verrechtlichung der internationalen Beziehungen. Staaten als Autoren, Adressaten und Wächter des Völkerrechts, number 16 in Freiburger Schriften zur Politikwissenschaft, Freiburg: Arnold-Berstraesser-Institut.

Fearon, James D. (1997): Signaling Foreign Policy Interests. Tying Hands Versus Sinking Costs, in: Journal of Conflict Resolution, 41, No. 1, 68-90.

- (1998): Bargaining, Enforcement, and International Cooperation, in: International Organization, 52, No. 2, 269-305.

Field, Andy (2016): An Adventure in Statistics. The Reality Enigma, London et al.: Sage.

Findlay, Mark;/Henham, Ralph J. (2005): Transforming International Criminal Justice: Retributive and Restorative Justice in the Trial, New York: Routledge.

Finnemore, Martha/Sikkink, Kathryn (1998): International Norm Dynamics and Political Change, in: International Organization, 52, No. 4, 887-917.

Fischer-Lescano, Andreas/Teubner, Gunther (2007): Fragmentierung des Weltrechts. Vernetzung globaler Regimes statt etatistischer Rechtseinheit, in: Stichweh, Rudolf/Albert, Mathias (Eds.): Weltstaat und Weltstaatlichkeit. Beobachtungen globaler politischer Strukturbildung, Wiesbaden: VS Verlag, 37-61.

Fitzmaurice, Malgoisa (2006): On the Protection of Human Rights, the Rome Statute and Reservations to Multilateral Treaties, in: Singapore Yearbook of International Law and Contributors, volume 10, Singapore: Faculty of Law, 133-173.

Franck, Thomas M. (1990): The Power of Legitimacy Among nations, New York: Oxford University Press.

Freeman, Mark (2006): Truth Commissions and Procedural Fairness, Cambridge: Cambridge University Press.

Frisch, Ragnar (1926): On a Problem in Pure Economics, Translated by JS Chipman. Preferences, Utility, and Demand: A Minnesota Symposium.

Galton, Francis (1886): Family Likeness in Stature, in: Proceedings of Royal Society, $40,42-72$.

Gauss, Carl Friedrich (1823): Theoria combinationes observationum erroribus minimis obnoxiae, Gottingae: Dietrich. 
Geiß, Robin/Bulinckx, Noemie (2006): International and Internationalized Criminal Tribunals. A Synopsis, in: International Review of the Red Cross, 88, No. 861, 49-63.

Gibney, Mark/Cornett, Linda/Wood, Reed/Haschke, Peter/Arnon, Daniel (2016): The Political Terror Scale 1976-2015, http://www.politicalterrorscale.org.

Giegerich, Thomas (1995): Vorbehalte zu Menschenrechtsabkommen: Zulässigkeit, Gültigkeit, und Prüfungskompetenzen von Vertragsgremien, in: Zeitschrift für ausländisches öffentliches Recht und Völkerrecht, 55, 713-782.

Ginsburg, Tom (2009): The Clash of Commitments at the International Criminal Court, in: Chicago Journal of International Law, 9, No. 2, 499-514.

Goldsmith, Jack L. (2003): The Self-Defeating International Criminal Court, in: The University of Chicago Law Review, 70, No. 1, 89-104.

Goldsmith, Jack L./Posner, Eric A. (2006): The Limits of International Law, Oxford University Press.

Goldstein, Judith/Kahler, Miles/Keohane, Robert O./Slaughter, Anne-Marie (2000): Introduction: Legalization and World Politics., in: International Organization, 54, No. 3, 385-399.

Goodliffe, Jay/Horne, Christine/Nielson, Daniel L. (2012): Dependence Networks and the International Criminal Court, in: International Studies Quarterly, 56, 131-147.

Goodman, Ryan/Jinks, Derek (2013): Socializing States. Promoting Human Rights Through International Law, New York: Oxford University Press.

Gujarati, Damodar N. (2003): Basic Econometrics, 4 edition, Boston et al.: McGrawHill.

Guzman, Andrew T. (2008a): How International Law Works, Oxford Scholarship Online.

- (2008b): International Tribunals: A Rational Choice Analysis, in: University of Pennsylvania Law Review, 157, No. 1, 171-235.

- (2013): International Organizations and the Frankenstein Problem, in: The European Journal of International Law, 24, No. 4, 999-1025. 
Hafner-Burton, Emilie M./Tsutsui, Kiyoteru (2005): Human Rights in a Globalizing World. The Paradox of Empty Promises, in: American Journal of Sociology, 110, No. 5, 1373-1411.

Hafner-Burton, Emilie M./Victor, David G./Lupu, Yonatan (2012): Political Science Research on International Law. The State of the Field, in: American Journal of International Law, 106, No. 1, 47-97.

Hathaway, Oona A. (2002): Do Human Rights Treaties Make a Difference?, in: Yale Law School Legal Scholarship Repository, 101, No. 839, 1935-2042.

Hawkins, Daren (2004): Explaining Costly International Institutions. Persuasion and Enforcable Human Righs Norms, in: International Studies Quarterly, 48, 779-804.

Hayner, Priscilla C. (2010): Unspeakable Truths. Transitional Justice and the Challenge of Truth Commissions, London: Routledge.

Hazan, Pierre (2006): Measuring the Impact of Punishment and Forgiveness. A Framework for Evaluating Transitional Justice, in: International Review of the Red Cross, 88, No. 861, 19-47.

Helfer, Laurence R./Slaughter, Anne-Marie (1997): Toward a Theory of Effective Supranational Adjudication, in: The Yale Law Journal, 107, 273-391.

- (2005): Why States Create International Tribunals. A Response to Professors Posner and Yoo, in: California Law Review, 93, No. 3, 899-956.

Henkin, Louis (1979): How Nations Behave. Law and Foreign Policy, 2 edition, New York: Columbia University Press.

Herdegen, Matthias (2013): Völkerrecht, 12 edition, München: C.H. Beck.

Heselhaus, Sebastian (2002): Resolution 1422 (2002) des Sicherheitsrates zur Begrenzung der Tätigkeit des Internationalen Szrafgerichtshofs, in: Zeitschrift für ausländisches öffentliches Recht und Völkerrecht, 62, 907-940.

Hillebrecht, Courtney/Straus, Scott (2017): Who Pursues the Perpetrators? State Cooperation with the ICC, in: Human Rights Quarterly, 39, No. 1, 162-188.

Hirschl, Ran (2004): Towards Juristocracy. The Origins and Consequences of the New Constitutionalism, Cambridge et al.: Harvard University Press. 
- (2008): The Judicialization of International Politics, in: Whittington, Keith E./Kelemen, R. Daniel/Caldeira, Gregory A. (Eds.): The Oxford Handbook of Law and Politics, Oxford: Oxford University Press, 119-141.

Hönnige, Christoph/Brouard, Sylvain (2017): Constitutional Courts as Veto Players. Lessons from the United States, France and Germany, in: European Journal of Political Research, 56, 529-552.

Horne, Cynthia M. (2012): Assessing the Impact of Lustration on Trust in Public Institutions and National Government in Central and Eastern Europe, in: Comparative Political Studies, 45, No. 4, 412-446.

Hughes, Edel; William A. Schabas/Thakur, Ramesh (2007): Atrocities and International Accountability: Beyond Transnational Justice, Tokyo: United Nations University Press.

Huntington, Samule P. (1991): The Third Wave. Democratization in the Late Twentith Century, Norman: University of Oklahoma Press.

Hurd, Ian (1999): Legitimacy and Authority in International Politics, in: International Organization, 53, No. 2, 379-408.

Jackson, Robert H. (1945): Report of Robert H. Jackson United States Representative to the International Conference on Military Trials, International Organization and Conference Series II.

Jeßberger, Florian (2017): The Modern Doctrinal Debate on the Crime of Aggression, in: Kreß, Claus (Ed.): The Crime of Agression. A Commentary, Chapter 10, Cambridge et al.: Cambridge University Press, 287.

Jetschke, Anja (2011): Der Kaiser hat ja gar keine Kleider an! - Strafverfolgung durch hybride Tribunale., in: Die Friedens-Warte. Journal of International Peace and Organization, 86, No. 1-2, 101-130.

Jorda, Claude (2004): The Major Hurdles and Accomplishments of the ICTY. What the ICC Can Learn From Them, in: Journal of International Criminal Justice, 2, No. 2, 572-584.

Katzenstein, Peter (1996): The Culture of National Security. Norms and Identity in World Politics, New York: Columbia University Press. 
— (2005): A World of Regions, Ithaca and London: Cornell University Press.

Katzenstein, Suzanne (2014): In the Shadow of the Crises: The Creation of International Courts in the Twentieth Century, in: Harvard International Law Journal, 55, No. 1, 151-209.

Keck, Margaret/Sikkink, Kathryn (1998): Activists beyond Borders. Advocacy Networks in International Politics, Ithaca and London: Cornell University Press.

Kelley, Judith (2007): Who Keeps International Commitments and Why? The International Criminal Court and Bilateral Nonsurrender Agreements, in: The American Political Science Review, 101, No. 3, 573-589.

Keohane, Robert O. (1984a): After Hegemony. Cooperation and Discord in the World Political Economy, Princeton University Press.

- (1984b): Reciprocity in International Relations, in: International Organization, 40, No. 1, 1-27.

Keohane, Robert O./Nye, Joseph S. (1977): Power and Interdependence: World Politics in Transition, Boston: Little, Brown and Company.

King, Gary/Keohane, Robert O./Verba, Sidney (1994): Designing Social Inquiry. Scientific Inference in Qualitative Research, Princeton: Princton University Press.

Kingsbury, Benedict (1999): Foreword. Is the Proliferation of International Courts and Tribunals a Systematic Problem, in: International Law and Politics, 31, 679-696.

Koh, Harold Hongju (1997): Why Do Nations Obey to International Law?, Yale Law School Legal Scholarship Repository.

Koremenos, Barbara (2007): If Only Half of International Agreements Have Dispute Resolution Provisions. Which Half Needs Explaining?, in: The Journal of Legal Studies, 36, No. 1, 189-212.

Koremenos, Barbara/Lipson, Charls/Snidal, Duncan (2001): The Rational Design of International Institutions, in: International Organization, 55, No. 4, 761-799.

Koskenniemi, Martti (2004): International Law and Hegemony. A Reconfiguration, in: Cambridge Review of International Affairs, 17, No. 2, 197-218.

- (2011): The Politics of International Law, Oxford, Portland and Oregon: Hart Publishing. 
Krasner, Stephen D. (1983): International Regimes, Ithaca: Cornell University Press.

— (1999): Sovereignty. Organized Hypocrisy, Princeton: Princton University Press.

Kreß, Claus (2010): Time for Decision: Some Thoughts on the Immediate Future of the Crime of Aggression: A Reply to Andreas Paulus, in: European Journal of International Law, 20, No. 4, 1129-1146.

Kritz, Neil J. (1996): Coming to Terms with Atrocities: A Review of Accountability Mechanisms for Mass Violations of Human Rights., in: Law and Contemporary Problems, 59, No. 4, 127-152.

Ku, Julian/Nzelibe, Jide (2006): Do International Criminal Tribunals Deter or Exacerbate Humanitarian atrocities?, in: Washington University Law Review, 84, No. 4, 777-833.

Leebaw, Bronwyn Anne (2008): The Irreconcilable Goals of Transitional Justice, in: Human Rights Quarterly, 30, No. 1, 95-118.

Lemkin, Rafael (1944): Axis Rule in Occupied Europe. Laws of Occupation, Analysis of Government, Proposals For Redress, Washington: Carnegie Endowment for International Peace, Division of International Law.

Lipscomp, Leigh-Ashley (2010): Beyond the Truth. Can Reparations Move Peace and Justice Forward in Timor-Leste?, in: Asia Pacific Issues, 93, 1-12.

Locke, John (1967 [1689]): Second Treatise, in: Laslett, Peter (Ed.): Two Treatises of Government. A Critical Edition with an Introcduction and Apparatus Criticus by Peter Laslett, 2 edition, Cambridge University Press, 285-446.

Long, Scott J./Freese, Jeremy (2001): Regression Models For Categorial Dependent Variables, Texas: Stata Press.

Magliveras, Gino, Konstantinos; Naldi (2013): The ICC Adresses Non-Cooperation By States Parties: The Malawi Decision, in: African Journal of Legal Studies, 6, 137-151.

Mahoney, James (2000): Path Dependence in Historical Sociology, in: Theory and Society, 29, No. 4, 507-548.

Majone, Giandomenico (2001): Two Logics of Delegation. Agency and Fiduciary Relations in EU Governance, in: European Union Politics, 2, No. 1, 103-122. 
Mearsheimer, John J. (1995): The False Promise of International Institutions, in: International Security, 19, No. 3, 5-49.

Mehmetoglu, Mehmet/Jakobsen, Tor Georg (2017): Applied Statistics Using STATA. A Guide for the Social Sciences, Los Angeles et al.: Sage.

Melander, Erik/Pettersson, Therése/Themnér, Lotta (2016): Organized Violence. 1989-2015, in: Journal of Peace Research, 53, No. 5, 727-742.

Merkel, Wolfgang (2004): Embedded and Defectice Democracies, in: Democratization, 11 , No. 5, 33-58.

Merrills, J.G. (1993): The Development of International Law by the European Court of Human Rights, Merrills, J.G.

Bueno de Mesquita, Bruce (2010): Principles of International Politics, 4 edition, Washington: CQ Press.

Milner, Helen (1997): Interests, institutions, and information. Domestic Politics and International Relations, Princeton: Princton University Press.

Minow, Martha (1998): Between Vengeance and Forgiveness. Facing History after Genocide and Mass Violence, Boston: Beacon Press.

Mochochoko, Phakiso (2001): The Agreement on Privileges and Immunities of the International Criminal Court, in: Fordham International Law Journal, 25, No. 3, 638-664.

Moore, Michael (1992): The Moral Worth of Retribution, in: Hirsch, Andrew/Ashworth, Andrew (Eds.): Principled Sentencing: Readings on Theory and Policy, Northeastern University Press, 179-219.

Moravcsik, Andrew (1997): Taking Preferences Seriuously. A Liberal Theory of International Relations, in: International Organization, 51, No. 4, 513-544.

- (2000): The Origins of Human Rights Regimes. Democratic Delegation in Postwar Europe, in: International Organization, 54, No. 2, 217-252.

- (2013): Liberal Theories of International Law, in: Dunoff, Jeffrey L./Pollack, Mark A. (Eds.): Interdisciplinary Perspectives on International Law and International Relations. The State of the Art, Cambridge: Cambridge University Press, 83-118. 
Moravcsik, Andrew/Legro, Jeffrey W. (1999): Is Anybody Still a Realist?, in: International Security, 24, No. 2, 5-55.

Morgenthau, Hans Joachim (1948): Politics among Nations. The Struggle for Power and Peace, New York: Alfred A. Knopf.

Moyn, Samuel (2014): Human Rights and the Uses of History, London and New York: Verso.

Neumayer, Eric (2005): Do Internationa Human Rights Treaties Improve Respect for Human Rights, in: Journal of Conflict Resolution, 49, 925-953.

- (2007): Qualified Ratification: Explaining Reservations to International Human Rights Treaties, in: Journal of Legal Studies, 36, No. 2, 397-429.

Newman, Dwight G. (2005): The Rome Statute, Some Reservations Concerning Amnesties, and a Distributive Problem, in: American University International Law Review, 20, No. 2, 293-357.

Nitsche, Dennis (2007): Der Internationale Strafgerichtshof und der Frieden. Eine vergleichende Analyse der Befriedungsfunktion internationaler Straftribunale, BadenBaden: Nomos.

Oberleitner, Gerd (2013): Humanitarian Law as a Source of Human Rights Law, in: Shelton, Dinah L. (Ed.): The Oxford Handbook of International Human Rights Law, Oxford: Oxford University Press, 257-294.

O'Brien, Melanie (2012): Prosecutorial Discretion as an Obstacle to Prosecution of United Nations Peacekeepers by the International Criminal Court, in: Journal of International Criminal Justice, 10, 525-545.

O'Connell, Mary Ellen (2002): Debating the Law of Sanctions, in: European Journal of International Law, 13, No. 1, 63-79.

Olásolo, Héctor (2005): The Triggering Procedure of the International Criminal Court, Legal Aspects of International Organization, volume 43, Leiden and Boston: Martinus Nijhoff Publishers.

Olsen, Tricia/Payne, Leigh A./Reiter, Andrew (2010): Transitional Justice In Balance: Comparing Processes, Weighing Efficacy, Washington: US Institute of Peace Press. 
Oye, Kenneth A. (1986): Cooperation under Anarchy, Princeton: Princton University Press.

Parisi, Francesco/Ghei, Nita (2003): The Role of Reciprocity In international Law, in: Cornell International Law Journal, 36, No. 1, 93-123.

Paulus, Andreas (2010): Second Thoughts on the Crime of Aggression, in: European Journal of International Law, 20, No. 4, 1117-1128.

Philippe, Xavier (2008): Sanctions for Violations of International Humanitarian Law: The Problem of the Division of Competences between National Authorities and Between National and International Authorities, in: International Review of the Red Cross, 90, No. 870, 359-341.

Pinchon, Jakob (2011): Internationaler Strafgerichtshof und Sicherheitsrat der Vereinten Nationen, number 218 in Beiträge zum ausländischen öffentlichen Recht und Völkerrecht, Berlin and Heidelberg: Max-Plamck-Institut für ausländisches Recht und Völkerrecht.

Popovski, Vesselin (2000): International Criminal Court. A Necessary Step Towards Global Justice, in: Security Dialogue, 31, No. 4, 405-419.

Posner, Eric A. (2004): The Decline of the International Court of Justice, Chicago Working Paper Series.

- (2014): The Twilight of Human Rights Law, Oxford: Oxford University Press.

Posner, Eric A./Figueiredo, Miguel (2005): Is the International Court of Justice Biased?, in: Journal of Legal Studies, 34, No. 2, 599-630.

Posner, Eric A./Yoo, John C. (2005a): Judicial Independence in International Tribunals, in: California Law Review, 93, No. 1, 1-74.

- (2005b): Reply to Helfer and Slaughter, in: California Law Review, 93, No. 3, 957-973.

Purvis, Nigel (1991): Critical Legal Studies in Public International Law, in: Harvard International Law Journal, 32, No. 1, 81-127.

Putnam, Robert D. (1988): Diplomacy and Domestic Politics: The Logic of Two-Level Games, in: International Organization, 42, No. 03, 427-460. 
Risse, Thomas (2000): 'Let's argue!': Communicative Action in World Politics, in: International Organization, 54, No. 1, 1-39.

Risse, Thomas/Ropp, Stephen/Sikkink, Kathryn (2013): The Persistent Power of Human Rights. From Commitment to Compliance, Cambridge: Cambridge University Press.

Romano, Cesare P.R. (1998): The Financing of the ICC, Discussion Paper.

- (1999): The Proliferation of International Judicial Bodies. Pieces of the Puzzle, in: International Law and Politics, 31, No. 4, 709-751.

Rowen, Jamie (2017): Searching for Truth in the Transitional Justice Movement, Cambridge: Cambridge University Press.

Sandoz, Ives (2001): Role of the ICRC in the Evolution and Devekopment of International Humanitarian Law, in: Nomos (Ed.): Humanitäres Völkerrecht. Politische, rechtliche und strafgerichtliche Dimensionen, Baden-Baden: Hasse, Jana; Müller, Erwin; Schneider, Patricia, 110-131.

Sands, Philippe (2016): East West Street, London: Weidenfeld and Nicholson.

Schabas, Wiliam A. (2000): Genocide in International Law, Cambridge: Cambridge University Press.

- (2004): United States Hostility to the International Criminal Court. It's all about the Security Council, in: European Journal of International Law, 15, No. 4, 701-720.

- (2011): An Introduction to the International Criminal Court, 4 edition, Cambridge: Cambridge University Press.

Scharpf, Fritz W. (1985): Die Politikverflechtungs-Falle. Europäische Integration und deutscher Föderalismus im Vergleich, in: Politische Vierteljahresschrift, 26, No. 4.

Schnell, Elke/Hill, Paul B./Esser, Elke (2013): Methoden der empirischen Sozialforschung, 10 edition, München: Oldenbourg Verlag.

Scott, Robert E. (2003): A Theory of Self-Enforcing Indefinite Agreements, in: Columbia Law Review, 103, No. 7, 1614-1699.

Shapiro, Martin (1981): Courts. A Comparative and Political Analysis, Chicago and London: University of Chicago Press. 
Shapiro, Martin/Stone Sweet, Alec (2002): On Law, Politics, and Judicialization, Oxford: Oxford University Press.

Shelton, Dinah L. (2000): Commitment and Compliance. The Role of Non-Binding Norms in the International Legal System, Oxford: Oxford University Press.

- (2009): Form, Function, and the Powers of International Courts, in: Chicago Journal of International Law, 9, No. 537, 1-29.

Shepsle, Kenneth A. (2010): Analizing Politics. Rationality, Behavior, and Institutions, 2 edition, New York, London: Norton.

Shepsle, Kenneth A./Weingast, Barry R. (1987): The Institutional Foundations of Committee Power, in: American Political Science Review, 81, 85-104.

Sikkink, Kathryn (2011): The Justice Cascade, London and New York: W. W. Norton and Company.

- (2017): Evidence for Hope. Making Human Rights Working in the 21th Century, Princeton: Princeton University Press.

Simmons, Beth A. (1998): The Compliance with International Agreements, in: Annual Review of Political Sciences, 1, 75-93.

- (2008): International Law and International Relations, in: The Oxford Handbook of Law and Politics, Oxford: Oxford University Press, 187-208.

- (2009): Mobilizing for Human Rights. International Law in Domestic Politics, Cambridge: Cambridge University Press.

Simmons, Beth A./Danner, Allison (2009): Credible Commitments and the International Criminal Court, Working Paper 2nd Annual Conference on Empirical Legal Studies.

- (2010): Credible Commitments and the International Criminal Court, in: International Organization, 64, No. 2, 225-256.

Simmons, Beth A./Jo, Hyeran (2016): Can the International Criminal Court Deter Atrocity?, in: International Organization, 70, No. 3, 443-475.

Simmons, Richard H., Beth A.; Steinberg (2007): International Law and International Relations. Scholarship at the Intersections of Principles and Politics, Cambridge: Cambridge University Press. 
Slaughter, Anne-Marie (1993): International Law and International Relations Theory. A Dual Agenda, in: The American Journal of International Law, 87, No. 2, 205-239.

- (2000a): Judicial Globalization, in: Virgina Journal of International Law, 40, 11031124.

- (2000b): A Liberal Theory of International Law, Proceeding of the 94th Annual Meeting.

Slaughter, Anne-Marie/Tulumello, Andrew S./Wood, Stepan (1998): International Law and International Relations Theory: A New Generation of Interdisciplinary Scholarship, in: American Journal of International Law, 92, 367-397.

Snyder, Jack L./Vinjamuri, Leslie (2003): Trials and Errors. Principle and Pragmatism in Strategies of International Justice, in: International Security, 28, No. 3, $5-44$.

Solera, Oscar (2010): The Definition of the Crime of Agression. Lessons Not Learned, in: Case Western Reserve Journal of International Law, 42, No. 3, 801-823.

Solingen, Etel (1998): Regional Orders at Century's Dawn. Global and Domestic Influence on Grand Strategy., Princeton: Princton University Press.

Sriram, Chandra Lekha (2003): Revolutions in Accountability. New Approaches to Past Abuses, in: American University International Law Review, 19, No. 2, 301-429.

Steinberg, Richard H. (2002): In the Shadow of Law or Power? Consensus-Based Bargaining and Outcomes in the GATT/WTO, in: International Organization, 56, No. 2, 339-374.

- (2004): Judicial Lawmaking at the WTO. Discursive, Constitutional, and Political Constraints, in: American Journal of International Law, 98, No. 2, 247-275.

- (2013): Wanted - Dead or Alive. Realism in international Law, in: Dunoff, Jeffrey L./Pollack, Mark A. (Eds.): Interdisciplinary Perspectives on International Law and International Relations, Cambridge University Press, 146-172.

Stone Sweet, Alec (1999): Judicialization and the Construction of Governance, in: Yale Law School Legal Scholarship Repository.

- (2002): Constitutional Courts and Parliamentary Democracy, in: West European Politics, 25, No. 1, 77-100. 
Subotic, Jelena (2009): Hijacked Justice. Dealing with the Past in the Balkans, Ithaca: Cornell University Press.

Swart, Mia (2008): Sorry Seems to Be The Hardest Word. Apology As A Form of Symbolic Reparation, in: South African Journal on Human Rights, 24, 50-70.

Tabak, Shana (2009): Article 124, War Crimes, and the Development of the Rome Statute, in: Georgetown Journal of International Law, 40, 1069-1099.

Teitel, Ruti G. (2003): Transitional Justice Genealogy, in: Harvard Human Rights Journal, 16, 69-94.

Teubner, Gunther (2005): Wandel der Rolle des Rechts in Zeiten der Globalisierung: Fragmentierung, Konstitutionalisierung und Vernetzung globaler Rechtsregime. Veranstaltung vom 2005, Rechtswissenschaftlicher Kongress anlässlich des "Deutschland in Japan Jahr 2005/2006", Tokio.

Tolley, Howard B. (1994): The International Commission of Jurists. Global Advocates for Human Rights, Philadelphia: University of Pennsylvania Press.

Tomuschat, Christian (2010): Gerichte als Geiselnehmer, Newspaper Article in the 'Frankfurter Allgemeine Zeitung', December 2010.

- (2014): Human Rights. Between Idealism and Realism, 3 edition, Oxford: Oxford University Press.

Vallinder, Torbjörn (1995): When the Courts Go Marching In, in: Tate, Neal C./Vallinder, Torbjörn (Eds.): The Global Expansion of Judicial Power, New York: New York University Press, 13-26.

Vinjamuri, Leslie/Boesenecker, Aaron (2007): Accountability and Peace Agreements. Mapping Trends from 1980 to 2006, Centre for Humanitarian Dialogs Report.

Vöneky, Silja (2007): Response - The Fight agianst Terrorism and the Rules of International Law - Comment on Paperes and Speeches of John Bellinger, Chief Legal Advisor to the United States State Department, in: German Law Journal, 8, No. 747-760.

Vöneky, Silja/Röben, Volker/Schorkopf, Frank (2004): The Fight Against Terrorism and the Rules of the Law of Warfare, in: Walter, Christian/Vöneky, Silja/Röben, Volker/Schorkopf, Frank (Eds.): Terrorism as a Challenge for National and International Law - Security Versus Liberty?, Berlin and Heidelberg: Springer, 925-950. 
Vorländer, Karl/Kant, Immanuel (1795/1973): Immanuel Kant. Kleinere Schriften zur Geschichtsphilosophie, Ethik und Politik, number 471 in Philosophische Bibliothek, Hamburg: Felix Meiner Verlag.

Walker, Neil (2008): Beyond Boundary Disputes and Basic Grids. Mapping the Global Disorder of Normative Orders, in: International Journal of Counstitutional Law, 6, No. 3-4, 373-396.

Waltz, Kenneth N. (1959): Man, the State and War. A Theoretical Analysis, New York: Columbia University Press.

- (1979): Theory of International Politics, Long Grove: Waveland Press, Columbia University.

Wartanian, Annie (2005): The ICC Prosecutor's Battlefield. Combating Atrocities While Fighting For States' Cooperation. Lessons From the U.N. Tribunals Applied to the Case of Uganda, in: Georgetown Journal of International Law, 36, 1290-1316.

Watts, Sean (2009): Reciprocity and the Law of War, in: Harvard International Law Journal, 50, No. 2, 365-434.

Weiffen, Brigitte (2012): Transitional Justice, in: Kollmorgen, Raj/Wagener, HansJürgen (Eds.): Handbuch der Transformationsforschung, Wiesbaden: VS Verlag, $749-754$.

Wendt, Alexander (1992): Anarchy is What States Make of It. The Social Construction of Power Politics, in: International Organization, 46, No. 4, 391-425.

- (2006): Driving with the Rearview Mirror. On the Rational Science of Institutional Design, in: Simmons, Richard H., Beth A.; Steinberg (Ed.): International Law and International Relations, New York: Cambridge University Press, 403-425.

Werle, Gerhard (2007): Individual Criminal Responsibility in Article 25 ICC Statute, in: Journal of International Criminal Justice, 5, 953-975.

Williams, Sharon A./Schabas, Wiliam A. (2008): Article 13 Exercise of Jurisdiction, in: Triffterer, Otto/Ambos, Kai (Eds.): Commentary on the Rome Statute of the International Criminal Court. Obsever's Notes, Article by Article, Beck, Hart and Nomos, 563-574.

Wippman, David (1999): Atrocities, Deterrence, and the Limits of International Justice, in: Fordham International Law Journal, 23, No. 2, 473-488. 
Zangl, Bernhard (2009): Judizialisierung als Bestandteil internationaler Rechtsherrschaft. Theoretische Debatten, in: Zangl, Bernhard (Ed.): Auf dem Weg zu internationaler Rechtsherrschaft? Streitbeilegung zwischen Politik und Recht, Frankfurt am Main: Campus Verlag, 11-36.

Zangl, Bernhard/Zürn, Michael (2004): Make Law Not War. Internationale und transnationale Verrechtlichung als Baustein für Global Governance, in: Meyer, Berthold (Ed.): Konfliktregelung und Friedensstrategien. Eine Einführung, Wiesbaden: VS Verlag, 523-544.

Zehr, Howard (2002): Restorative Justice, Intercourse: Good Books.

Zürn, Michael (2011): Vier Modelle einer globalen Ordnung in kosmopolitischer Absicht, in: Politische Vierteljahresschrift, 52, No. 1, 78-118. 


\section{Eigenständigkeitserklärung}

1. Die Gelegenheit zum vorliegenden Promotionsvorhaben ist mir nicht kommerziell vermittelt worden. Insbesondere habe ich keine Organisation eingeschaltet, die gegen Entgelt Betreuerinnen und Betreuer für die Anfertigung von Dissertationen sucht oder die mir obliegenden Pflichten hinsichtlich der Prüfungsleistungen für mich ganz oder teilweise erledigt.

2. Ich versichere, dass ich die eingereichte Dissertation (A Commitment is A Commitment is A Commitment - Why States Constrain and Customize their Commitments to the International Criminal Court) selbstständig und ohne unerlaubte Hilfsmittel verfasst habe; fremde Hilfe habe ich dazu weder unentgeltlich noch entgeltlich entgegengenommen und werde dies auch zukünftig so halten. Anderer als der von mir angegebenen Hilfsmittel und Schriften habe ich mich nicht bedient. Alle wörtlich oder sinngemäß den Schriften anderer Autoren entnommenen Stellen habe ich kenntlich gemacht.

3. Die eingereichte Dissertation habe ich nicht bereits in einem anderen Prüfungsverfahren vorgelegt.

4. Des Weiteren ist mir bekannt, dass Unwahrhaftigkeiten hinsichtlich der vorstehenden Erklärung die Zulassung zur Promotion ausschließen bzw. später zum Verfahrensabbruch oder zur Rücknahme des erlangten Titels berechtigen.

Julia Hagen 


\section{Acknowledgments}

Many people made this project possible. I wish to thank my first supervisor Prof. Dr. Anja Jetschke from the Chair of International Relations in Göttingen for all I've learned from her about international relations theory and research design of social sciences and for encouraging me to find my own voice. I want to thank my second supervisor Prof. Dr. Dr. h.c. Kai Ambos from the Chair of Criminal Law and Procedure, Comparative Law \& International Criminal Law in Göttingen for his perspective on international criminal law that made me think out of the box of political sciences and take into consideration the needs and challenges of international criminal courts. I want to thank my third supervisor Prof. Dr. Christoph Hönnige from the Chair of Comparative Politics and the Political System of the Federal Republic of Germany for allowing me to join his colloquia in order to receive corrective input in the fields of statistics and comparative politics.

Additionally, I want to thank my colleagues at the Chair of International Relations - especially Sören Münch, Claudia Marggraf, and Besmira Sinanaj - and the attendees of the colloquia for their questions and comments during different stages of the project. Special gratitude goes to Patrick Theiner for so many inspiring discussions about international politics and for always giving advice in terms of science and life.

I would like to thank Steven Jonathan Pitock for his editorial feedback in order to improve language and comprehensibility.

I'm grateful to Sarah Sinram, Benjamin Engst, Dana Ionescu, Helene Gerhards, and Johannes Fioole for sharing their thoughts on comparative politics and political theory and most of all for making these years good ones.

I want to thank my family for always supporting me and letting me spend so many hours reading and writing in their beautiful flower gardens. I want to thank my mother, Ingrid Egle, for teaching me to think politically and never stop being curious about what is going on in the world.

Last but most important, I want to thank Daniel Hagen for his love and his patience. 